ROSÂNGELA DOS SANTOS MOTTA

\title{
ESTUDO LABORATORIAL DE AGREGADO RECICLADO DE RESÍDUO SÓLIDO DA CONSTRUÇÃO CIVIL PARA APLICAÇÃO EM PAVIMENTAÇÃO DE BAIXO VOLUME DE TRÁFEGO
}

Dissertação apresentada à Escola Politécnica da Universidade de São Paulo para obtenção do Título de Mestre em Engenharia de Transportes. 
ROSÂNGELA DOS SANTOS MOTTA

\section{ESTUDO LABORATORIAL DE AGREGADO RECICLADO DE RESÍDUO SÓLIDO DA CONSTRUÇÃO CIVIL PARA APLICAÇÃO EM PAVIMENTAÇÃO DE BAIXO VOLUME DE TRÁFEGO}

Dissertação apresentada à Escola Politécnica da Universidade de São Paulo para obtenção do Título de Mestre em Engenharia de Transportes.

Área de Concentração:

Engenharia de Transportes

Orientador:

Prof $^{a}$. Livre-Docente

Liedi Légi Bariani Bernucci 
MOTTA, R. S. Estudo laboratorial de agregado reciclado de resíduo sólido da construção civil para aplicação em pavimentação de baixo volume de tráfego. 2005. 134f. Dissertação (Mestrado em Engenharia de Transportes) - Escola

Politécnica, Universidade de São Paulo, São Paulo.

\section{ERRATA}

\begin{tabular}{|c|c|c|c|}
\hline Folha & Linha & Onde se lê & Leia-se \\
\hline 58 & 19 & $\begin{array}{l}\text { material relativamente } \\
\text { abrasivo }\end{array}$ & material de mais fácil quebra \\
\hline 58 & 21 & sempre & às vezes \\
\hline 62 & 2 & com na & com base na \\
\hline 63 & 15 & totalmente & relativamente \\
\hline 75 & 22 & Tabela 5.6. & $\begin{array}{l}\text { Tabela 5.6. O tempo “0” (zero) } \\
\text { significa, no caso do Índice de } \\
\text { Suporte Califórnia, } \\
\text { compactação seguida } \\
\text { imediatamente de } 4 \text { dias de } \\
\text { imersão em água destilada. O } \\
\text { tempo " } 28 \text { " significa } 24 \text { dias de } \\
\text { cura úmida (na caixa) seguida } \\
\text { de } 4 \text { dias de imersão em água } \\
\text { destilada. Idem para "90" e } \\
\text { “180" dias de cura. }\end{array}$ \\
\hline 90 & 13 & ...não-destrutivo) & $\begin{array}{l}\text {...não-destrutivo, alterando } \\
\text { insignificantemente a estrutura } \\
\text { inicial do material) }\end{array}$ \\
\hline 95 & 9 & deformação específica & deformação \\
\hline
\end{tabular}


FICHA CATALOGRÁFICA

Motta, Rosângela dos Santos

Estudo laboratorial de agregado reciclado de resíduo sólido da construção civil para aplicação em pavimentação de baixo volume de tráfego / R.S. Motta. -- São Paulo, 2005.

$134 \mathrm{p}$.

Dissertação (Mestrado) - Escola Politécnica da Universidade de São Paulo. Departamento de Engenharia de Transportes.

1.Infra-estrutura de transportes 2.Pavimentação

3.Reciclagem de resíduos urbanos

I.Universidade de São Paulo. Escola Politécnica. Departamento de Engenharia de Transportes II.t. 
À minha família,

aо meu querido Giovanni e a todas as pessoas que foram

e que são especiais em minha vida. 
O presente trabalho foi realizado com o apoio do Conselho Nacional de Desenvolvimento Científico e Tecnológico - CNPq - Brasil. 


\section{AGRADECIMENTOS}

Ao $\boldsymbol{C N P q}$, pela bolsa de mestrado;

Ao Laboratório de Tecnologia de Pavimentação da EPUSP;

Ao Departamento de Engenharia de Transportes da EPUSP;

À PMSP, pelo fornecimento do material e auxílio na coleta;

Ao Laboratório de Química dos Materiais de Construção do IPT, e também ao Centro de Pesquisa e Desenvolvimento em Construção Civil do Departamento de Construção Civil da EPUSP;

À Cinconegui Fernandes, Pedro Mazzei, Dan Schneider, Valdecir Papazissis;

Aos professores Maria Eugênia Boscov e Vanderley John por diversas sugestões que enriqueceram este trabalho;

Ao professor Orlando Strambi pela ajuda nas traduções de texto de língua inglesa;

Ao amigo Sérgio Ângulo pelas explicações, ensaios e empréstimo de material;

Ao amigo Breno Barra pela motivadora frase "No final dá tudo certo!";

À todos aqueles que são alunos, pesquisadores e amigos do LTP, em especial ao amigo

Moisés Abdou que muito ajudou com a parte experimental neste último ano;

À amiga Diomária Santos, nossa querida secretária;

Ao amigo Erasmo Alves, pela força (literalmente falando) nos ensaios realizados;

Ao amigo Edson de Moura, pela ajuda em incontáveis momentos deste trabalho;

À amiga Patrícia Barboza, parceira desde o primeiro dia de aula do curso de graduação, que foi o início de tudo;

À família Manassero, especialmente a Giorgio e Cecília, pelo grande incentivo;

À minha família, de maneira especial aos meus pais Ismael e Creusa, e também à minha avó Helena que sempre me fez crer que estudar continuamente é tarefa essencial na vida;

Ao meu querido Giovanni, companheiro de todas as horas e alegria de meus dias, pelo grande incentivo;

E de forma mais do que especial à minha mestra e amiga Liedi Bernucci, cujo sentimento de generosidade é um dos mais intensos e verdadeiros que já vi. Agradeço pela oportunidade de desenvolver esta pesquisa, e sobretudo pela atenção, carinho e colaboração durante todo este mestrado em que tive a felicidade de aprender tantas coisas novas. 


\section{RESUMO}

A crescente quantidade de resíduos sólidos da construção civil gerada em cidades de médio e grande portes tem sido fonte de preocupação em todo o mundo em função de questões ambientais, econômicas e até sociais. Desta forma, a reciclagem dos resíduos de construção para a produção de agregados torna-se uma alternativa interessante, principalmente em função de normas e pesquisas já existentes que podem garantir sua aplicação. A pavimentação com agregados reciclados já vem sendo amplamente realizada em alguns países onde, inclusive, já existe conhecimento consolidado sobre o assunto. No Brasil, as primeiras experiências que remetem ao uso de agregados reciclados em pavimentação datam de meados da década de 80 . Desde então, poucas pesquisas sobre o tema vem sendo realizadas, embora haja a necessidade de se procurar novas técnicas e materiais no setor de infra-estrutura rodoviária, uma vez que o país possui somente cerca de $10 \%$ de suas vias, muitas vezes urbanas, em condição pavimentada. Este trabalho analisa laboratorialmente aspectos físicos e de comportamento mecânico do agregado reciclado da cidade de São Paulo, a ser utilizado em camadas de base, sub-base ou reforço do subleito de pavimento, em substituição aos materiais convencionais, com enfoque em vias urbanas de baixo volume de tráfego. O estudo envolveu a análise do agregado reciclado in natura, além de sua mistura com $4 \%$ de cal ou $4 \%$ de cimento Portland, como forma de promover um aumento da resistência do material. Além disso, foram realizados alguns ensaios com brita graduada (material comumente empregado em pavimentos), a fim de comparar resultados. Concluiu-se que o agregado reciclado analisado é de uso promissor em pavimentação, dadas suas propriedades físicas e mecânicas satisfatórias, comparáveis a tradicionais materiais estabilizados granulometricamente ou mesmo a brita graduada simples. Ademais, a adição de cal ou cimento Portland apresenta-se como excelente alternativa quanto ao requisito de aumento de resistência do material reciclado. 


\begin{abstract}
The increasing amount of construction and demolition waste generated in mediumsized and large cities has become a source of concern all over the world due to environmental, economic and even social issues. Thus, the recycling of construction and demolition waste to produce aggregates becomes an interesting alternative mainly because of existing specifications and researches that can guarantee its application. Paving with recycled aggregates has already been largely done in some countries where there is even a consolidated knowledge about the subject. In Brazil, preliminary experiences that refer to the use of recycled aggregates in pavement layers date from the mid $80 \mathrm{~s}$. Since then, few researches on the subject have been conducted, although it is necessary to look for new techniques and materials in the road infra-structure sector, since the country has only about $10 \%$ of its roads, many times urban ones, in paved condition. This work analyses recycled aggregates from São Paulo City as a material to be used in base, subbase or subgrade reinforcement courses in urban roads of low-volume traffic, to replace conventional materials. So, physical and mechanical behaviour aspects of the material were observed by means of laboratory tests. This study involved the analysis of recycled aggregate in natura, as well as its mix with $4 \%$ of lime or $4 \%$ of Portland cement, to promote a gain in strength. Moreover, some tests were made using graded crushed rock (that is commonly used as a pavement material) so as to compare the results. It was concluded that recycled aggregate is promising for paving, given its satisfactory physical and mechanical properties, comparable to traditional granulometrically stabilized materials or even to simple graded crushed rock. The addition of lime or Portland cement is an excellent alternative concerning the increase in strength of those recycled materials.
\end{abstract}




\section{SUMÁRIO}

LISTA DE FIGURAS

LISTA DE TABELAS

LISTA DE ABREVIATURAS E SIGLAS

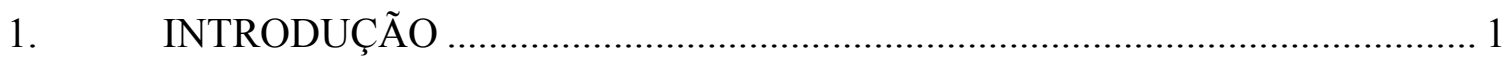

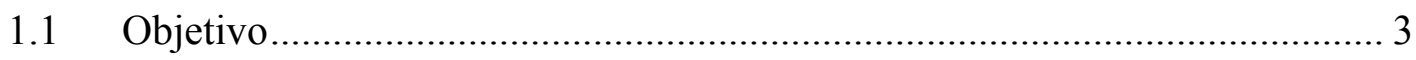

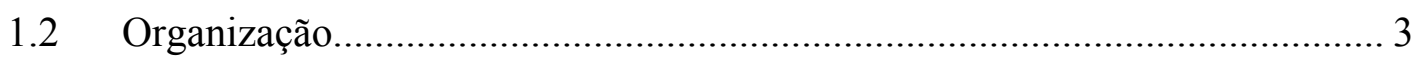

2. RESÍDUOS SÓLIDOS DA CONSTRUÇÃO CIVIL ...................................... 5

3. RECICLAGEM DE RESÍDUOS SÓLIDOS DA CONSTRUÇÃO CIVIL ....... 12

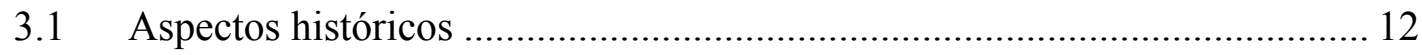

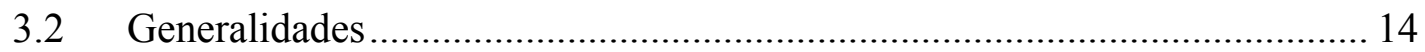

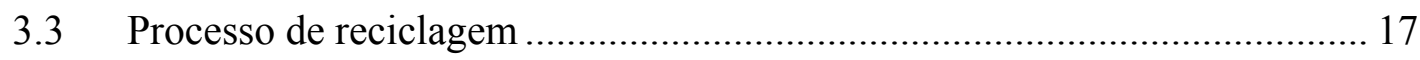

3.4 Possíveis empregos para o agregado reciclado ........................................ 22

3.5 Usina recicladora da PMSP.................................................................. 23

4. PAVIMENTAÇÃO COM AGREGADO RECICLADO ................................. 27

4.1 Pavimentação com agregado reciclado no mundo ..................................... 27

4.2 Pavimentação com agregado reciclado no Brasil........................................ 29

4.2.1 Algumas experiências práticas ............................................................ 29

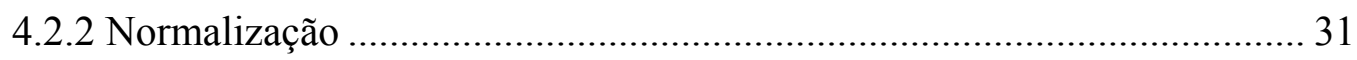

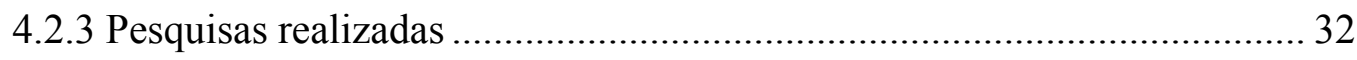

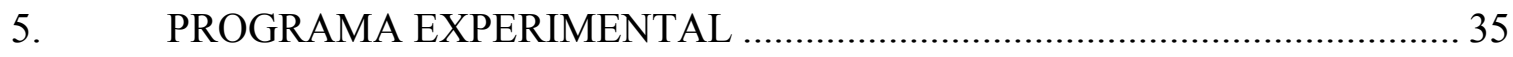

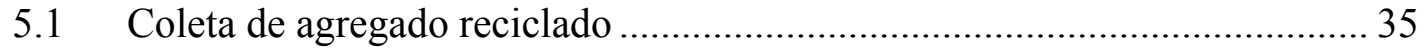

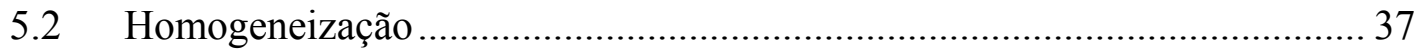

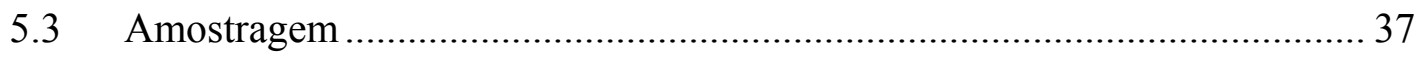

5.4 Caracterização física do agregado reciclado ............................................. 38

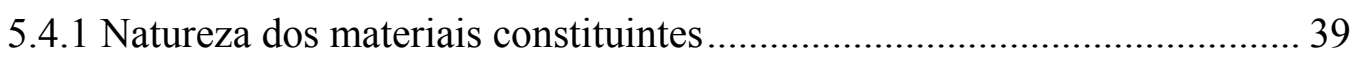

5.4.2 Distribuição granulométrica ............................................................... 42

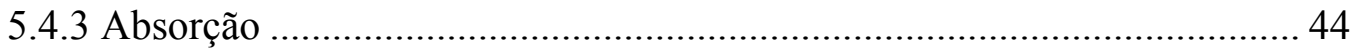


5.4.4 Determinação da atividade pozolânica. 46

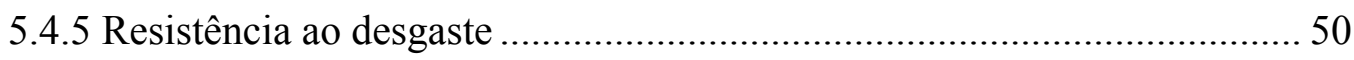

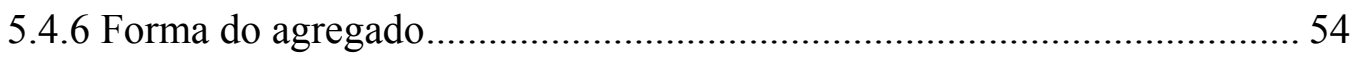

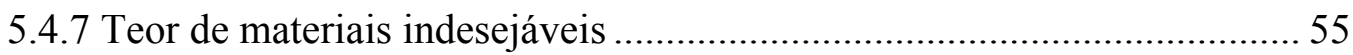

5.5 Determinação da energia de compactação .................................................. 58

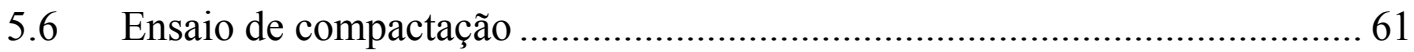

5.7 Variação do peso específico aparente seco com a energia de compactação. 69

5.8 Caracterização do comportamento mecânico................................................. 73

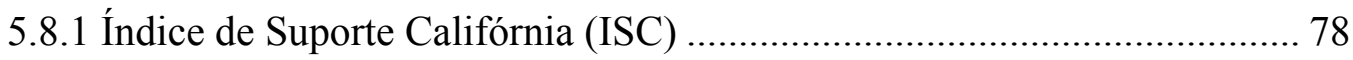

5.8.2 Resistência à Tração por Compressão Diametral.................................... 85

5.8.3 Resistência à Compressão Simples ......................................................... 89

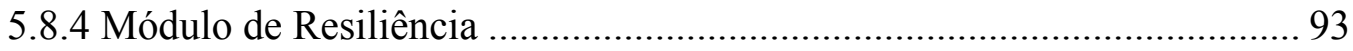

5.9 Comparativo do agregado reciclado com a brita graduada ........................ 114

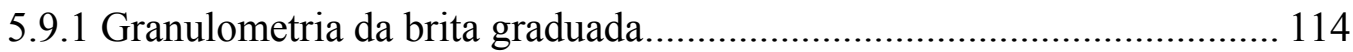

5.9.2 Variação do peso específico aparente seco com a energia de compactação

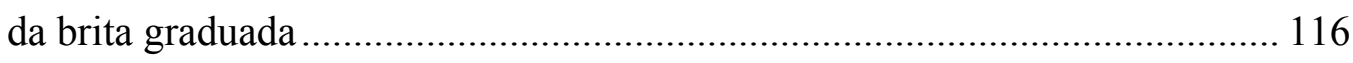

5.9.3 Índice de Suporte Califórnia (ISC) da brita graduada........................... 119

5.9.4 Módulo de Resiliência da brita graduada............................................ 120

6. CONCLUSÕES E COMENTÁRIOS ........................................................ 123

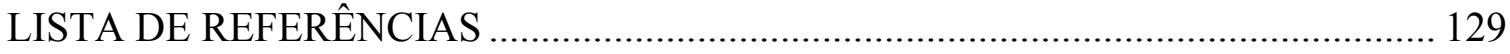

ANEXO A

ANEXO B 


\section{LISTA DE FIGURAS}

Figura 2.1: Descarte irregular no Córrego dos Meninos (Sto. André/São Bernardo do Campo - SP) e à beira da Avenida do Estado (SP capital) ................................. 8

Figura 3.1: Catação realizada em recicladora de Belo Horizonte (MG) - foto retirada

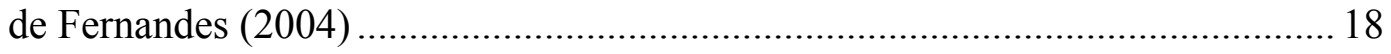

Figura 3.2: Material separado magneticamente em recicladora de São Paulo (SP)... 18

Figura 3.3: Lançamento de resíduo de construção no britador, em Belo Horizonte

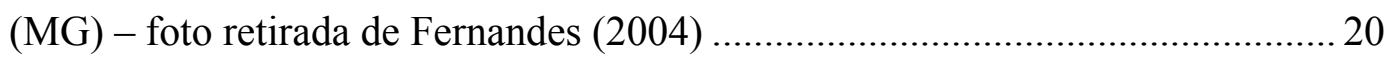

Figura 3.4: Vista de britador primário, em Jundiaí (SP) ....................................... 20

Figura 3.5: Vista inferior do peneirador, em Jundiaí (SP) ...................................... 21

Figura 3.6: Separação conforme granulometria, em Jundiaí (SP) ............................ 21

Figura 3.7: Agregado reciclado em esteira transportadora com eletroímã - foto

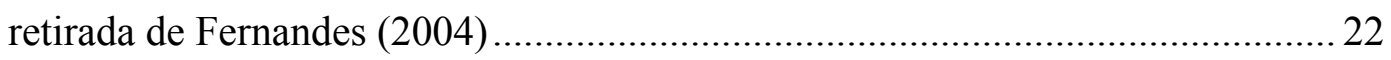

Figura 3.8: Molhagem do resíduo no caminhão, ao chegar na recicladora - foto retirada de Fernandes (2004), com modificações.............................................. 22

Figura 3.9: Vista da usina recicladora da PMSP .................................................... 24

Figura 3.10: Resíduo cinza antes da reciclagem .................................................. 24

Figura 3.11: Resíduo vermelho antes da reciclagem .............................................. 24

Figura 3.12: Agregados reciclados de concreto classificados granulometricamente. 25

Figura 3.13: Agregado reciclado tipo brita corrida ............................................... 25

Figura 3.14: Vista do britador de impacto da recicladora da PMSP ......................... 26

Figura 3.15: Vista do peneirador mecânico da usina de reciclagem da PMSP, com aberturas de peneiras de 4,8mm, 20mm e 40mm ............................................ 26

Figura 4.1: Esquema de pavimento da Rua Gervásio da Costa, segundo figura retirada de Bodi et al. (1995), com modificações ................................................. 30

Figura 4.2: Corte do pavimento com base executada com RCD reciclado em Belo Horizonte, segundo foto retirada de Pinto (1999)

Figura 4.3: Execução da sub-base de pavimento com agregado reciclado na Rua Adelina Amaral Pongelupe em Belo Horizonte (MG) ........................................ 31

Figura 5.1: Coleta do agregado reciclado na usina da PMSP ................................... 36

Figura 5.2: Disposição dos sacos no caminhão por meio de pá carregadeira ............. 36 
Figura 5.3: Chegada do caminhão e descarregamento das amostras no LTP-EPUSP36

Figura 5.4: Disposição das porções ensacadas para secagem ................................... 37

Figura 5.5: Revolvimento do material para homogeneização.................................... 37

Figura 5.6: Separação do agregado reciclado em porções representativas ................. 38

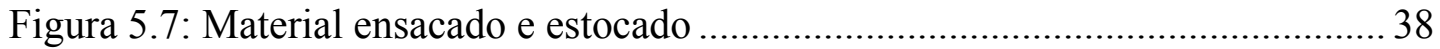

Figura 5.8: Composição do agregado reciclado estudado........................................ 40

Figura 5.9: Concreto e argamassa retidos nas peneiras citadas ................................ 41

Figura 5.10: Brita retida nas peneiras citadas ....................................................... 41

Figura 5.11: Telha e tijolo retidos nas peneiras citadas ............................................. 41

Figura 5.12: Piso e azulejo retidos nas peneiras citadas ........................................ 41

Figura 5.13: Telha de amianto retida nas peneiras citadas..................................... 41

Figura 5.14: Material fino passado na peneira 4,76mm .......................................... 41

Figura 5.15: Concentrações granulométricas dos materiais constituintes do agregado

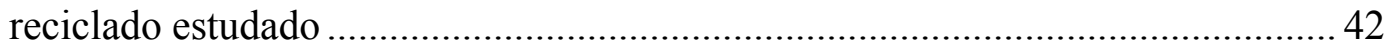

Figura 5.16: Peneiramento a seco do agregado reciclado ...................................... 43

Figura 5.17: Distribuição granulométrica do agregado reciclado estudado............... 43

Figura 5.18: Agregado reciclado submetido à absorção de água............................... 44

Figura 5.19: Equipamento para o ensaio de Chapelle Modificado, segundo figura retirada de Morales (1994) apud Raverdy et al. (1980), com modificações ......... 47

Figura 5.20: Equipamento "Los Angeles" do LTP-EPUSP ...................................... 50

Figura 5.21: Frações granulométricas submetidas à abrasão "Los Angeles" ............ 51

Figura 5.22: Aparência do agregado reciclado retido e passado na peneira $1,7 \mathrm{~mm}$

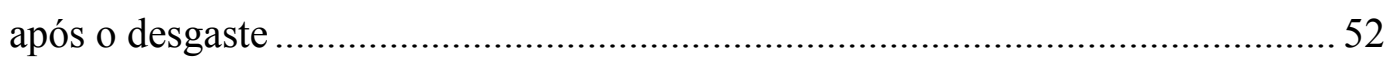

Figura 5.23: Leitura para determinação da forma do agregado reciclado estudado .. 55 Figura 5.24: Frações granulométricas para determinação da forma do agregado

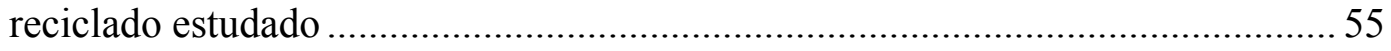

Figura 5.25: Fração de materiais indesejáveis encontrada no agregado reciclado estudado 56

Figura 5.26: Fração de gesso encontrada no agregado reciclado estudado................. 56

Figura 5.27: Fração de madeira encontrada no agregado reciclado estudado.............57

Figura 5.28: Fração de plástico encontrada no agregado reciclado estudado.............57 
Figura 5.29: Variação granulométrica após ensaio de ISC com corpos-de-prova compactados em energias Proctor Normal e Intermediária, em função de porcentagens passantes (ou retidas)

Figura 5.30: Variação granulométrica após ensaio de ISC com corpos-de-prova compactados em energias Proctor Normal e Intermediária, em função de porcentagens retidas não acumuladas. 60

Figura 5.31: Cilindro tripartido e soquete Proctor utilizados. 62

Figura 5.32: Cilindro com o agregado reciclado compactado em seu interior 62

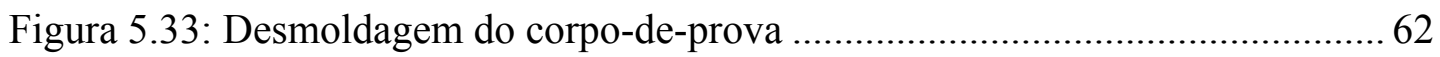

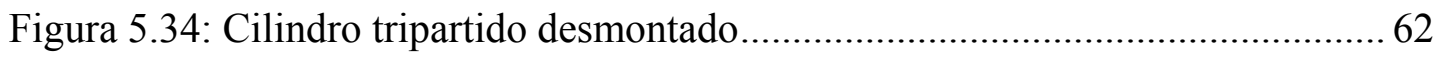

Figura 5.35: Curvas de compactação do agregado reciclado estudado...................... 63

Figura 5.36: Água em excesso na preparação da amostra com umidade de 14\%...... 64

Figura 5.37: Variação granulométrica após compactação em 6 camadas e 57 golpes por camada, em função de porcentagens passantes (ou retidas) 66

Figura 5.38: Variação granulométrica após compactação em 6 camadas e 57 golpes por camada, em função de porcentagens retidas não acumuladas

Figura 5.39: Variação granulométrica após compactação em 13 camadas e 26 golpes por camada, em porcentagens passantes (ou retidas) 67

Figura 5.40: Variação granulométrica após compactação em 13 camadas e 26 golpes por camada, em função de porcentagens retidas não acumuladas 68

Figura 5.41: Equipamento MCV (criado por Parsons) do LTP-EPUSP .................... 70

Figura 5.42: Compactação no equipamento MCV adaptado do LTP-EPUSP ............ 70

Figura 5.43: Variação do peso específico aparente seco em função da energia de compactação aplicada no ensaio com o equipamento MCV adaptado 71

Figura 5.44: Variação granulométrica após compactação no MCV adaptado, em função de porcentagens passantes (ou retidas) 72

Figura 5.45: Variação granulométrica após compactação no MCV adaptado, em função de porcentagens retidas não acumuladas 73

Figura 5.46: Colocação de tubo de PVC para que houvesse sustentação do corpo-deprova durante o período de cura 76

Figura 5.47: Corpo-de-prova de agregado reciclado recoberto por fina camada de gesso em sua extremidade superior. 77 
Figura 5.48: Armazenamento dos corpos-de-prova em caixa com serragem

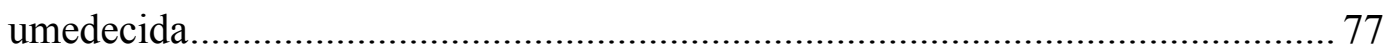

Figura 5.49: Compactação do corpo-de-prova para ensaio de ISC ........................... 79

Figura 5.50: Imersão dos corpos-de-prova em água destilada................................ 79

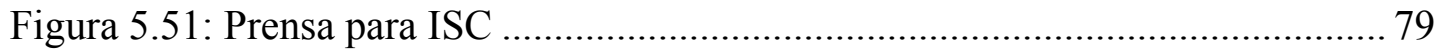

Figura 5.52: Compactador mecânico do LTP-EPUSP .............................................. 80

Figura 5.53: Resultado dos ensaios de Índice de Suporte Califórnia.........................8 80

Figura 5.54: Corpo-de-prova rompido no ensaio de Resistência à Tração por Compressão Diametral .86

Figura 5.55: Resultado dos ensaios de Resistência à Tração por Compressão

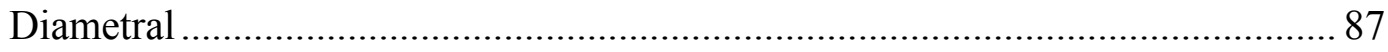

Figura 5.56: Corpo-de-prova no ensaio de Resistência à Compressão Simples ........ 90

Figura 5.57: Resultado dos ensaios de Resistência à Compressão Simples .............. 91

Figura 5.58: Equipamento triaxial de carga repetida e sistema de aquisição de dados para obtenção do Módulo de Resiliência no LTP-EPUSP .95

Figura 5.59: Módulo de Resiliência de corpo-de-prova com 4\% de cimento Portland aos 90 dias de cura .98

Figura 5.60: Evolução do Módulo de Resiliência com o tempo de cura em corpos-deprova in natura, para $\sigma_{\mathrm{d}}$ de $0,200 \mathrm{MPa}$ 100

Figura 5.61: Evolução do Módulo de Resiliência com o tempo de cura em corpos-deprova in natura, para $\sigma_{\mathrm{d}}$ de $0,150 \mathrm{MPa}$ 101

Figura 5.62: Evolução do Módulo de Resiliência com o tempo de cura em corpos-deprova com $4 \%$ de cal, para $\sigma_{\mathrm{d}}$ de $0,200 \mathrm{MPa}$. 102

Figura 5.63: Evolução do Módulo de Resiliência com o tempo de cura em corpos-deprova com $4 \%$ de cal, para $\sigma_{\mathrm{d}}$ de $0,150 \mathrm{MPa}$.

Figura 5.64: Evolução do Módulo de Resiliência com o tempo de cura em corpos-deprova com adição de $4 \%$ de cimento Portland, para $\sigma_{\mathrm{d}}$ de $0,200 \mathrm{MPa}$ 104

Figura 5.65: Evolução do Módulo de Resiliência com o tempo de cura em corpos-deprova com adição de $4 \%$ de cimento Portland, para $\sigma_{d}$ de $0,150 \mathrm{MPa}$ 105

Figura 5.66: Módulo de Resiliência após cura de 28 dias em corpos-de-prova in natura, com 4\% de cal e com 4\% de cimento Portland, para $\sigma_{\mathrm{d}}$ de 0,200MPa .. 106 
Figura 5.67: Módulo de Resiliência após cura de 28 dias em corpos-de-prova in natura, com 4\% de cal e com 4\% de cimento Portland, para $\sigma_{\mathrm{d}}$ de $0,150 \mathrm{MPa} . .107$

Figura 5.68: Módulo de Resiliência após cura de 90 dias em corpos-de-prova in natura, com 4\% de cal e com 4\% de cimento Portland, para $\sigma_{\mathrm{d}}$ de 0,200MPa .. 108 Figura 5.69: Módulo de Resiliência após cura de 90 dias em corpos-de-prova in natura, com 4\% de cal e com 4\% de cimento Portland, para $\sigma_{\mathrm{d}}$ de 0,150MPa .. 109

Figura 5.70: Módulo de Resiliência após cura de 180 dias em corpos-de-prova in natura, com cal e cimento Portland, para $\sigma_{\mathrm{d}}$ de $0,200 \mathrm{MPa}$ 110

Figura 5.71: Módulo de Resiliência após cura de 180 dias em corpos-de-prova in natura, com $4 \%$ de cal e $4 \%$ de cimento Portland, para $\sigma_{\mathrm{d}}$ de $0,150 \mathrm{MPa}$ 111

Figura 5.72: Resultados de Módulo de Resiliência em campo, para agregados reciclados de concreto, segundo figura retirada de Reid (2000), com modificações 113

Figura 5.73: Resultados de Módulo de Resiliência de campo para agregados reciclados de concreto, segundo figura retirada de Arm (2001), com modificações

Figura 5.74: Curva granulométrica da brita graduada e do agregado reciclado estudados 115

Figura 5.75: Curva granulométrica da brita graduada pesquisada frente às faixas especificadas pela ABNT e pelo DER-SP. 116

Figura 5.76: Comparação de resultados do ensaio MCV adaptado da brita graduada e do agregado reciclado estudados 117

Figura 5.77: Variação granulométrica da brita graduada e do agregado reciclado após compactação em MCV adaptado, em porcentagens passantes (ou retidas)

Figura 5.78: Variação granulométrica da brita graduada e do agregado reciclado após compactação em MCV adaptado, em porcentagens retidas não acumuladas 118

Figura 5.79: Comparativo entre ISC da brita graduada e do agregado reciclado .... 119 Figura 5.80: Módulo de Resiliência das britas graduadas compactadas em energias Proctor Modificada e Intermediária 121

Figura 5.81 Comparação de Módulo de Resiliência da brita graduada e do agregado reciclado in natura. 122 


\section{LISTA DE TABELAS}

Tabela 2.1: Geração de resíduos em países da União Européia (EC, 1999) 6

Tabela 2.2: Geração de resíduos em municípios do estado de São Paulo (PINTO, 1999; SCHNEIDER, 2003)

Tabela 3.1: Porcentagem reutilizada ou reciclada em países da União Européia (EC, 1999)

Tabela 3.2: Preço de base de pavimento executada pela PMSP (janeiro de 2005) ${ }^{(}$.. 26

Tabela 5.1: Teores de absorção de água encontrados em algumas pesquisas. .45

Tabela 5.2: Resultados de atividade pozolânica do agregado reciclado obtidos pelo Método de Chapelle Modificado 48

Tabela 5.3: Abrasão "Los Angeles" obtida com alguns agregados reciclados brasileiros

Tabela 5.4: Porcentagem estimada de materiais contaminantes contidos no agregado reciclado coletado

Tabela 5.5: Teor de umidade ótima e peso específico aparente seco obtidos em algumas pesquisas 65

Tabela 5.6: Tempos de cura empregados 76

Tabela 5.7: Resultado dos ensaios de Índice de Suporte Califórnia .81

Tabela 5.8: Limites de ISC e expansão especificados pela NBR 15115 (2004). 82

Tabela 5.9: ISC de agregados reciclados obtidos em algumas pesquisas realizadas em outros países

Tabela 5.10: ISC de agregados reciclados obtidos em algumas pesquisas brasileiras

Tabela 5.11: Resultado dos ensaios de Resistência à Tração por Compressão Diametral 88

Tabela 5.12: Resultado dos ensaios de Resistência à Compressão Simples 92

Tabela 5.13: Tensões aplicadas para condicionamento do corpo-de-prova no ensaio de Módulo de Resiliência 96

Tabela 5.14: Tensões de carregamento aplicadas na etapa de registro no sistema de aquisição de dados no ensaio de Módulo de Resiliência. 
Tabela 5.15: Diâmetro dos diferentes tipos de brita utilizados para compor a brita

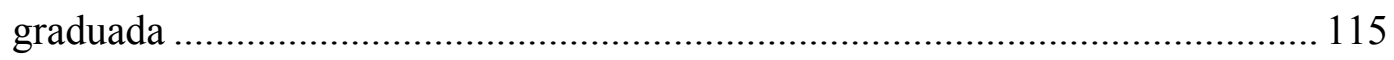




\section{LISTA DE ABREVIATURAS E SIGLAS}

ABNT - Associação Brasileira de Normas Técnicas

ALT-MAT - Alternative Materials in Road Construction

ANTT - Agência Nacional de Transportes Terrestres

BGTC - Brita graduada tratada com cimento

CBR - California Bearing Ratio

CONAMA - Conselho Nacional do Meio Ambiente

DER-SP - Departamento de Estradas de Rodagem do Estado de São Paulo

DETR - Department of the Environment, Transport and the Regions (do Reino Unido)

DNER - Departamento Nacional de Estradas de Rodagem

DNPM - Departamento Nacional de Produção Mineral

EC - European Commission

EPA - The U. S. Environmental Protection Agency

EPUSP - Escola Politécnica da Universidade de São Paulo

FWD - Falling Weight Deflectometer

GEIPOT - Empresa Brasileira de Planejamento de Transportes

HRB - Highway Research Board

IPT - Instituto de Pesquisas Tecnológicas

ISC - Índice de Suporte Califórnia

LTP-EPUSP - Laboratório de Tecnologia de Pavimentação da Escola Politécnica da Universidade de São Paulo

MR - Módulo de Resiliência

PMSP - Prefeitura do Município de São Paulo

PMF - Pré-misturado a frio

PVC - Poli (cloreto de vinila)

RCD - Resíduo(s) de construção e demolição

RCS - Resistência à Compressão Simples

RTCD - Resistência à Tração por Compressão Diametral

UTS - University of Technology, Sidney 


\section{INTRODUÇÃO}

A intensa geração de resíduos sólidos da construção civil em cidades de grande e médio portes tem sido motivo de preocupação em diversos países, já que a mesma envolve questões de ordem ambiental, social e financeira. Em função disto, muitos pesquisadores em todo o mundo vêm tentando encontrar alternativas para que os problemas decorrentes deste processo sejam minimizados, ou até mesmo sanados, com vistas à sustentabilidade do setor construtivo.

No Brasil, como forma de dar atenção à questão dos resíduos de construção, foi publicada a Resolução CONAMA n 307 no ano de 2002 (ANEXO A), que determina diretrizes para uma efetiva redução dos impactos ambientais provocados por estes materiais. Estabeleceu-se que os geradores são os responsáveis pelo resíduo produzido e que o objetivo prioritário deve ser a não geração e, caso isto não seja possível, deve-se considerar a redução, reutilização, reciclagem e disposição final (nesta ordem). No caso da disposição final, os materiais devem ser encaminhados para locais denominados aterros de resíduos da construção civil ou áreas de destinação de resíduos, e serem depositados de modo que seja possível sua utilização ou reciclagem futura.

Segundo mostram diversas pesquisas realizadas e até mesmo a experiência prática, os resíduos de construção civil transformados em agregados reciclados podem ser empregados, dentre outras coisas, em construção de pavimentos.

A importância da pavimentação é constantemente realçada como sendo uma forma de redução dos custos de transporte, mas outros aspectos de difícil quantificação dos benefícios são igualmente relevantes, uma vez que promove integração social, acesso garantido em qualquer época do ano e redução do pó (com conseqüente redução de doenças respiratórias), o que contribui para a melhoria da qualidade de vida da população. 
No Brasil, segundo dados do GEIPOT (2000), apenas 9,5\% da malha rodoviária do país é pavimentada, o que equivale a aproximadamente $165.000 \mathrm{~km}$ dos mais de $1.700 .000 \mathrm{~km}$ existentes. Esses números apontam uma grande carência no setor, que é o responsável pela maior parte do transporte de cargas e de passageiros no país, já que $61,5 \%$ do movimento de cargas e $95 \%$ do movimento de passageiros (ANTT, 2002) amparam-se no transporte rodoviário.

Em termos urbanos, sabe-se que nos municípios brasileiros há parcela expressiva da malha viária ainda em terra ou cascalhada, principalmente nas periferias ou em bairros mais pobres. A cidade de São Paulo, por exemplo, de acordo com dados da própria prefeitura, possui mais de $2.900 \mathrm{~km}$ a serem pavimentados, o que corresponde a aproximadamente $18 \%$ dos $16.339 \mathrm{~km}$ existentes, sem contar os quase $1.500 \mathrm{~km}$ de que não se tem informação (PMSP, 1998).

A utilização do agregado reciclado proveniente de resíduo de construção pode ser uma alternativa interessante aos materiais convencionalmente utilizados, para promover um aumento na oferta de vias pavimentadas nos grandes centros urbanos ou mesmo nas cidades de médio porte brasileiras, caracterizadas principalmente por baixo volume de tráfego ${ }^{(1)}$.

A princípio, o principal atrativo dos agregados reciclados é o aspecto econômico, pois estes materiais normalmente têm sido vendidos por preços inferiores aos dos granulares tradicionalmente empregados em pavimentação. A título de exemplo, a PMSP (Prefeitura do Município de São Paulo) executa um metro cúbico de uma base com agregado reciclado por preço cerca de $18 \%$ inferior ao do mesmo tipo de obra com o uso de brita graduada simples (segundo tabela de preços vigente em janeiro de 2005). De acordo com Kulaif (2001), o agregado reciclado apresenta custos menores de capital, energia e transporte (neste caso devido à possibilidade de melhor distribuição espacial da produção) em relação ao material natural.

(1) Segundo Bernucci (1995), uma via de baixo volume de tráfego é caracterizada por um tráfego previsto de até $10^{6}$ repetições de carga equivalente ao eixo padrão de $82 \mathrm{kN}$, durante o período de projeto a ser considerado. 
A exploração de jazidas minerais para a produção de agregados naturais é responsável por grandes impactos ambientais, verificando-se entre eles poeira, poluição visual e sonora, tráfego ou ainda poluição de recursos hídricos e assoreamento dos mesmos (DETR, 2000). No Brasil, "os agregados minerais - areia e pedra britada - constituem hoje o segmento do setor mineral mais explorado e comercializado no país" (LEVY, 2001, p.70), com a produção chegando a alcançar 320,4 milhões de toneladas no ano de 2003 (DNPM, 2004). A pavimentação consome $30 \%$ do mercado brasileiro de pedras britadas, o que equivaleu a cerca de 96 milhões de toneladas da produção do ano de 2003 (DNPM, 2004). No caso da Europa, de acordo com Hill et al. (2001), o consumo estimado de agregados neste setor é em torno de 1 bilhão de toneladas por ano.

Hill et al. (2001) ainda citam que para manter os níveis de desenvolvimento e construção e reduzir a utilização de agregados naturais há duas opções: otimizar o uso destes últimos ou empregar materiais alternativos.

\section{$1.1 \quad$ Objetivo}

Esta pesquisa objetiva analisar laboratorialmente aspectos físicos e de comportamento mecânico de agregados reciclados de resíduo sólido da construção civil para uso em camadas de base, sub-base ou reforço do subleito, em substituição aos materiais convencionalmente utilizados, com enfoque em vias de baixo volume de tráfego. Procura-se comparar resultados dos ensaios de comportamento mecânico realizados com o agregado reciclado in natura, com a incorporação de $4 \%$ de cal e também com $4 \%$ de cimento Portland, além de um material de referência constituído de brita graduada simples.

\subsection{Organização}

Este estudo está organizado em seis capítulos. O primeiro é a INTRODUÇÃO do trabalho onde são estabelecidos os objetivos e a organização da pesquisa. O segundo capítulo aborda o tema RESÍDUOS SÓLIDOS DA CONSTRUÇÃO CIVIL e trata das políticas adotadas para enfrentar a questão dos resíduos de construção, além de quantificar a geração destes em diversos locais. $O$ capítulo três, intitulado 
RECICLAGEM DE RESÍDUOS SÓLIDOS DA CONSTRUÇÃO CIVIL, engloba alguns aspectos históricos, além de números referentes à reciclagem em diversos países e do próprio processo de reciclagem. Já o quarto capítulo, denominado PAVIMENTAÇÃO COM AGREGADO RECICLADO, discorre sobre aspectos como a normalização para este tipo de obra em alguns países e descreve, no caso brasileiro, algumas experiências práticas e pesquisas neste campo. O capítulo cinco, cujo título é PROGRAMA EXPERIMENTAL, relata detalhadamente a pesquisa com o agregado reciclado de São Paulo, desde a coleta do material até a sua caracterização física e mecânica (incluindo neste caso, a avaliação do material com a incorporação de cal ou cimento Portland), sendo alguns dos resultados comparados com os de ensaios conduzidos com brita graduada simples. Por fim, o sexto capítulo traz as CONCLUSÕES E COMENTÁRIOS de todo o estudo. 


\section{RESÍDUOS SÓLIDOS DA CONSTRUÇÃO CIVIL}

Segundo a Resolução CONAMA (2002), os resíduos sólidos da construção civil também conhecidos pela sigla RCD (resíduos de construção e demolição) - são definidos como materiais "provenientes de construções, reformas, reparos e demolições de obras de construção civil, e os resultantes da preparação e da escavação de terrenos, tais como: tijolos, blocos cerâmicos, concreto em geral, solos, rochas, metais, resinas, colas, tintas, madeiras e compensados, forros, argamassa, gesso, telhas, pavimento asfáltico, vidros, plásticos, tubulações, fiação elétrica, etc., e são comumente chamados de entulhos de obras, caliça ou metralha".

A geração destes materiais, em diversos lugares do mundo, tem sido motivo de preocupação, em virtude da expressiva quantidade produzida.

Em Hong Kong, na China, os dados apontam para uma geração diária de 22.000 toneladas de resíduos de construção no ano de 1991, que incluem as 16.000 toneladas dispostas em aterros, em vias públicas e em canais de deposição marinha (POON, 1997).

Na região de Nova Gales do Sul na Austrália (que engloba cidades como Sidney, Melbourne e a capital do país Camberra), a estimativa de geração de resíduos de construção e demolição no ano de 1997 é de 1,56 milhões de toneladas (UTS, 1999), representando cerca de 6.000 toneladas diárias.

Já nos Estados Unidos, calcula-se que, no ano de 1996, a produção de resíduos chegou a aproximadamente 136 milhões de toneladas, perfazendo um total per capita de $1,27 \mathrm{~kg}$ de material por habitante por dia, devendo-se ressaltar que não estão incluídos neste montante os resíduos de pavimentos e pontes (EPA, 1998).

Em relação à Europa, as quantidades de resíduos de construção geradas em alguns de seus países podem ser analisadas através da Tabela 2.1, que foi retirada de EC (1999). 
Tabela 2.1: Geração de resíduos em países da União Européia (EC, 1999)

\begin{tabular}{|c|c||c|c||}
\hline País & $\begin{array}{c}\text { População } \\
\text { aprox. } \\
{\left[\times \mathbf{1 0}^{3} \text { hab] }\right.}\end{array}$ & $\begin{array}{c}\text { Geração } \\
\text { RCD } \\
{\left[\times \mathbf{1 0}^{3} \text { ton/dia] }\right.}\end{array}$ & $\begin{array}{c}\text { Geração de RCD } \\
\text { per capita } \\
{[\mathbf{k g} / \mathbf{a n o}]}\end{array}$ \\
\hline Alemanha & 82.012 & 961,5 & 3658 \\
\hline Bélgica & 10.170 & 111,1 & 3408 \\
\hline Áustria & 8.068 & 84,6 & 3272 \\
\hline Dinamarca & 5.275 & 34,3 & 2030 \\
\hline Finlândia & 5.132 & 30,3 & 1841 \\
\hline Holanda & 15.567 & 64,4 & 1291 \\
\hline Reino Unido & 58.902 & 214,7 & 1137 \\
\hline Suécia & 8.844 & 18,9 & 666 \\
\hline Irlanda & 3.652 & 6,1 & 518 \\
\hline França & 58.492 & $75,6^{(\mathrm{a})}$ & 403 \\
\hline Itália & 57.461 & $64,1^{(\mathrm{a})}$ & 348 \\
\hline Espanha & 39.299 & $41,7^{(\mathrm{a})}$ & 331 \\
\hline Portugal & 9.934 & $9,6^{(\mathrm{a})}$ & 302 \\
\hline Grécia & 10.487 & $6,4^{(\mathrm{a})}$ & 191 \\
\hline & & & \\
\hline
\end{tabular}

(a) Não são considerados resíduos de pavimentação, escavação, vegetação e tubulações de drenagem, água, gás ou eletricidade.

Observa-se na Tabela 2.1 que em países como Alemanha, Bélgica, Áustria e Dinamarca a geração anual per capita atinge números extremamente elevados quando comparada a países como Suécia, Irlanda, França ou Espanha (embora devase considerar que todos estes últimos, exceto a Suécia, não incluem alguns tipos de resíduos no montante estimado).

No Brasil, os números relacionados à geração de resíduos de construção são escassos (ÂNGULO et al., 2002; SCHNEIDER, 2003), mas alguns deles são apresentados na Tabela 2.2, que mostra a produção anual destes materiais em seis cidades pertencentes ao estado de São Paulo. 
Tabela 2.2: Geração de resíduos em municípios do estado de São Paulo (PINTO, 1999; SCHNEIDER, 2003)

\begin{tabular}{|c|c|c|c||c|}
\hline Município & $\begin{array}{c}\text { População } \\
\text { aprox. } \\
{\left[\times \mathbf{1 0}^{\mathbf{3}} \mathbf{h a b}\right]}\end{array}$ & $\begin{array}{c}\text { Geração } \\
\text { RCD } \\
{[\text { ton/dia] }}\end{array}$ & $\begin{array}{c}\text { Geração aprox. } \\
\text { RCD per capita } \\
\text { [kg/ano] }\end{array}$ & Ano \\
\hline Jundiaí & 293 & $712^{(\mathbf{b})}$ & 758 & 1997 \\
\hline Ribeirão Preto & 456 & $1.043^{(\mathrm{b})}$ & 714 & 1995 \\
\hline São José do Rio Preto & 324 & $687^{(\mathrm{b})}$ & 662 & 1997 \\
\hline Santo André & 626 & $1.013^{(\mathrm{b})}$ & 505 & 1997 \\
\hline São Paulo & 10.000 & $16.000^{(\mathrm{c})}$ & 499 & 2003 \\
\hline São José dos Campos & 486 & $733^{(\mathrm{b})}$ & 471 & 1995 \\
\hline
\end{tabular}

(b) PINTO (1999)

(c) SCHNEIDER (2003)

(d) São considerados 26 dias úteis mensais

Verifica-se na Tabela 2.2 que há grande variação em termos de geração per capita entre as cidades analisadas, sendo que o município de São José dos Campos apresenta número significativamente inferior aos das cidades de Jundiaí e Ribeirão Preto, por exemplo, demonstrando que os setores de construção e reforma destas últimas estão em plena atividade. Já o município de São Paulo apresenta uma geração de resíduos diária elevadíssima, em relação às demais cidades citadas, mas como detém uma grande população, isto se reflete em uma quantidade per capita baixa quando comparada com as demais.

Confrontando-se a Tabela 2.2 com a Tabela 2.1, embora deva-se considerar que alguns dos países mencionados nesta última não contabilizam alguns tipos de resíduos nos números apresentados, é possível observar que as cidades brasileiras citadas chegam a apresentar geração per capita superior a de países inteiros, como França, Itália, Espanha, Portugal, Grécia, Suécia e Irlanda.

Deve-se ressaltar que uma parte significativa dos dados relacionados às quantidades geradas é resultado direto da definição de resíduos de construção e demolição em cada local, além da possibilidade de variação em função de sua estrutura industrial, de suas características tecnológicas de construção, de seu nível de desenvolvimento, etc (ÂNGULO et al., 2002). 
No Brasil, a preocupação com os grandes montantes de resíduos de construção gerados vai mais além, em função de um agravante que é a disposição irregular, que ocorre principalmente em locais como vias, rios, córregos, terrenos baldios e áreas de mananciais, o que contribui para a degradação urbana (Figura 2.1).
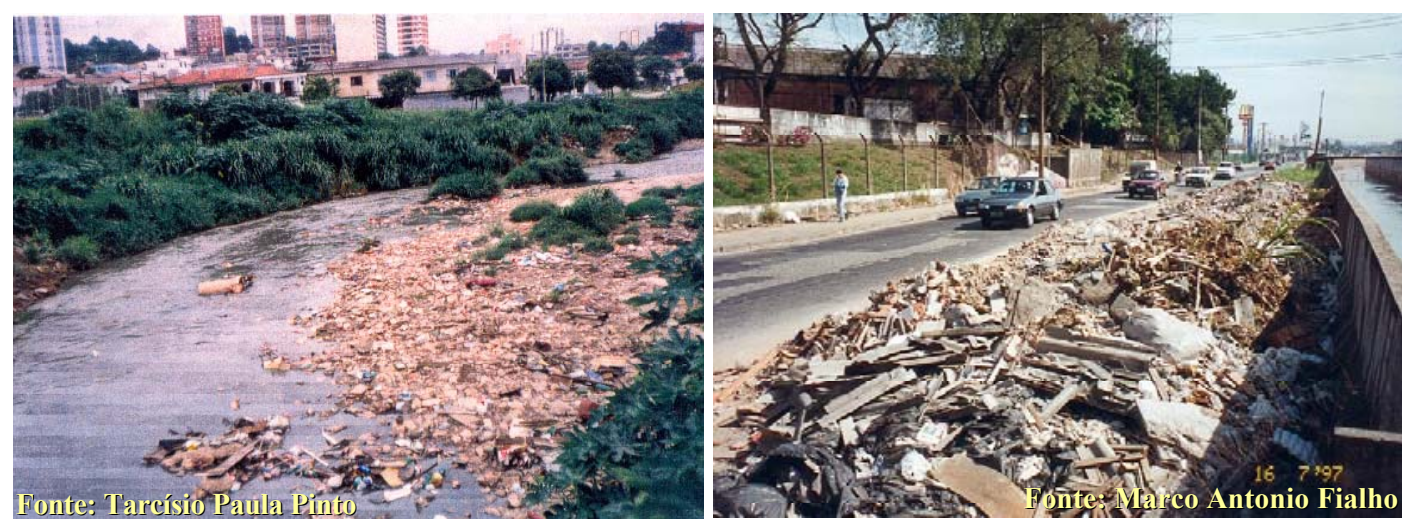

Figura 2.1: Descarte irregular no Córrego dos Meninos (Sto. André/São Bernardo do Campo - SP) e à beira da Avenida do Estado (SP capital)

No município de São Paulo, por exemplo, cuja produção diária de resíduos de construção ficou em torno de 16.000 toneladas no ano de 2003, estima-se que somente cerca de um terço do total gerado (em torno de 5.300 toneladas por dia) chegou aos aterros públicos (SCHNEIDER, 2003). Isto significa que aproximadamente $70 \%$ do montante produzido na cidade acabou sendo descartado ilegalmente.

Schneider (2003) menciona que os números referentes às quantidades geradas não correspondem ao total de resíduos produzidos, uma vez que nem todas as áreas públicas são limpas diariamente e os aterros ilegais recebem uma quantidade ignorada destes materiais.

Os resíduos sólidos da construção civil dispostos irregularmente podem trazer riscos à população, já que podem se tornar foco de proliferação de transmissores de doenças (SCHNEIDER, 2003), provocar o assoreamento dos recursos hídricos e obstruir os sistemas de drenagem (DETR, 2000) com conseqüente aumento das enchentes nas estações chuvosas. 
No Brasil, quando coletados para disposição final adequada, os resíduos de construção são encaminhados para unidades de aterro. Segundo Ângulo et al., (2003), estes materiais são os grandes responsáveis pelo esgotamento destes locais de destinação em cidades de médio e grande portes, uma vez que correspondem a mais de 50\% dos resíduos sólidos urbanos. Pinto (1999) mostrou em sua pesquisa que esta porcentagem pode chegar a $70 \%$ da massa de resíduos sólidos.

Muitas vezes, o esgotamento dos aterros pode implicar em dois tipos de problemas: um relacionado a gastos adicionais dos recursos públicos com desapropriações que visam a criação de novas áreas de destinação de resíduos, e outro à dificuldade de se encontrar locais adequados nas grandes cidades para a implementação destes novos aterros de resíduos, uma vez que áreas livres estão localizadas em distâncias remotas e, muitas vezes, pertencem a locais ambientalmente protegidos (BODI et al., 1995). Em São Paulo, uma parte significativa dos resíduos de construção chega a ser "exportada" e depositada irregularmente em outras municipalidades da área metropolitana, e esta distância adicional é somada aos custos de transporte e disposição (ÂNGULO et al., 2002).

Em termos de gastos envolvidos com o sistema de coleta, transporte e destinação final dos resíduos de construção civil, Schneider (2003) relata que, entre os anos de 1993 e 2002, os mesmos chegaram a mais de R\$ 263 milhões (vigentes no ano de 2002).

Em vários países da Europa, a destinação dos resíduos de construção para aterros tem sido cada vez menos tolerada; como forma de inibi-la e de incentivar a reciclagem, novas leis vem sendo instauradas e uma política de taxação de aterros vem sendo adotada.

As taxas impostas aos aterros variam significativamente de país para país na Europa, com extremos como no caso da Inglaterra, onde a taxa é de aproximadamente $€ 3,20$ por tonelada, ao caso da Dinamarca, onde o valor chega a ser em torno de $€ 50,00$ 
por tonelada. Na Dinamarca, inclusive, a média de reciclagem aumentou substancialmente em cerca de 900\% (desde 1987) com a evolução da taxa de deposição de resíduos de construção em aterros (SCHNEIDER, 2003). Isto também ocorreu na Finlândia, como relata Levy (2001), onde ocorreu um rápido crescimento na produção de concreto reciclado a partir da implementação, no ano de 1998, de um sistema de tributação sobre resíduos.

Além da fixação de taxas aos aterros, alguns países como Inglaterra, Holanda e Finlândia passaram também a prescrever taxas às matérias-primas oriundas de atividade de mineração como forma de fomentar o uso de agregados reciclados. $\mathrm{Na}$ Inglaterra, por exemplo, são taxados areia, cascalho e pedras (SCHNEIDER, 2003).

No entanto, segundo Hendriks e Janssen (2001), o encaminhamento dos resíduos de construção para a disposição final não é uma alternativa correta. De acordo com os pesquisadores, este procedimento poderia resultar em desperdício de matéria-prima, emissão de poluentes indesejáveis e perdas de energia e espaço, embora esta seja a prática mais comum na gestão destes materiais, segundo a EPA (1998). Nos Estados Unidos, por exemplo, estima-se que cerca de 35 a $45 \%$ dos resíduos de construção foram conduzidos à deposição em aterros no ano de 1996 (EPA, 1998).

Em alguns países da Europa, antes mesmo da demolição das edificações, é necessário apresentar às autoridades uma documentação que relate como os resíduos produzidos serão tratados; como ilustração, na Suécia, o plano de gestão deve descrever como será a destinação de cada um dos materiais gerados no processo de demolição (SCHNEIDER, 2003).

A composição dos resíduos de construção pode variar significativamente e está condicionada a características específicas da região geradora.

Pinto (1999) cita que a madeira é muito presente em construções dos Estados Unidos e do Japão, enquanto que na Europa e no Brasil sua presença é menos significativa. 
Costa e Ursella (2003) citam que na Itália a composição dos resíduos de construção não perigosos varia em função de fatores como materiais disponíveis, além de tipo e técnica de construção local.

Na Holanda, mais de 90\% dos resíduos de construção e demolição contém alvenaria e concreto e do restante fazem parte materiais como madeiras, metais, embalagens e plásticos (HENDRICKS e JANSSEN, 2001).

No Brasil, o típico resíduo de construção é uma mistura composta de cerâmica ou blocos de concreto, argamassa, concreto armado, aço, plástico, amianto e madeira, sendo que a porção de produtos oriundos do gesso tem aumentado e tende a se tornar uma parte significativa do resíduo nos próximos anos (ÂNGULO et al., 2002). Nos Estados Unidos e na Europa, o gesso é encontrado em larga escala nas construções (PINTO, 1999).

De forma geral, a maior parte dos resíduos de construção e demolição, tanto no Brasil quanto na Bélgica ou em Hong Kong, é composta por materiais de origem mineral como argamassa, concreto e cerâmica (PINTO, 1999; EC, 1999). 


\section{RECICLAGEM DE RESÍDUOS SÓLIDOS DA CONSTRUÇÃO CIVIL}

\subsection{Aspectos históricos}

O reaproveitamento de resíduos de construção já é praticado há muito tempo, pois os romanos já empregavam tijolos, telhas e louça cerâmica moída como pozolanas ${ }^{(2)}$ (SANTOS, 1975).

Entretanto, foram as grandes catástrofes deste século, como terremotos e guerras, que impulsionaram a prática do uso de material reciclado (LIMA, 1999). Tem-se como exemplo o que aconteceu após a II Guerra Mundial, onde a Europa, particularmente a Alemanha, teve que enfrentar as milhões de toneladas de resíduos remanescentes deste episódio e ainda a grande demanda por materiais a serem utilizados na reedificação das cidades. Nesta época, o governo alemão decretou ser prioridade a reconstrução da infra-estrutura de transportes, e o país se tornou pioneiro na reciclagem de resíduos da construção civil para a produção de materiais para pavimentação (LUND, 1993).

Com o desenvolvimento ocorrido nas últimas décadas, houve um incremento da quantidade de resíduos de construção gerada na Europa e nos Estados Unidos; durante os anos 70 e 80 surgiu o interesse pela reciclagem como forma de controlar este aumento, e foi aí que as atenções se voltaram para a separação do resíduo coletado (LUND, 1993). No final dos anos 80, o aterro dos resíduos de construção nos países desenvolvidos deixou de ser atrativo para o poder público em termos econômicos, uma vez que o custo da deposição chegou a alcançar até mais de U\$ 100 por tonelada (LUND, 1993). Além disso, também contribuiu para o interesse pela reciclagem a escassez de áreas para a implementação de novos aterros (SCHNEIDER, 2003).

No Brasil, a reciclagem de resíduos de construção iniciou-se ainda nos anos 80, com a utilização de pequenos moinhos instalados durante a construção de edifícios, onde

\footnotetext{
${ }^{(2)} \mathrm{O}$ item 5.4.4 deste trabalho apresenta a definição de pozolana.
} 
os resíduos de alvenaria eram reaproveitados para a produção de argamassas (LIMA, 1999).

De forma pioneira, a Prefeitura do Município de São Paulo implantou, no ano de 1991, a primeira usina recicladora do Brasil (CARNEIRO et al., 2001), em Itatinga, na zona sul da cidade, com a finalidade de produzir agregados reciclados para subbase de pavimentos. Este equipamento de reciclagem permaneceu desativado durante alguns anos e mais tarde voltou a operar no bairro de Itaquera, na zona leste do município (SCHNEIDER, 2003).

Ao longo da década de 90, algumas usinas recicladoras foram implementadas em municípios brasileiros, sendo gerenciadas pelas prefeituras ou por particulares. De acordo com Nunes (2004), atualmente existem 12 cidades no Brasil que possuem ao todo 14 usinas de reciclagem operando ou em pré-operação. Este número difere significativamente daquele referente aos Estados Unidos, pois este país possui cerca de 3500 unidades de reciclagem, segundo a EPA (1998).

Embora um certo número de usinas recicladoras tenha sido instalado no Brasil dos anos 90 até os dias de hoje, a publicação das primeiras normas nacionais relacionadas aos agregados reciclados de resíduos de construção só ocorreu em 2004, quando a ABNT lançou 4 especificações que tratam desde a instalação de recebimento do material até a sua aplicação em pavimentação ou em concreto sem função estrutural. São estas normas:

- NBR 15113 - Resíduos sólidos da construção civil e resíduos inertes Aterros - Diretrizes para projeto, implantação e operação;

- NBR 15114 - Resíduos sólidos da construção civil e resíduos inertes - Área de reciclagem - Diretrizes para projeto, implantação e operação;

- NBR 15115 - Agregados reciclados de resíduos sólidos da construção civil Execução de camadas de pavimentação - Procedimentos;

- NBR 15116 - Agregados reciclados de resíduos sólidos da construção civil Utilização em pavimentação e preparo de concreto sem função estrutural Requisitos. 
Concomitantemente com a instalação de novas usinas recicladoras e com a criação de normas para produção e utilização dos agregados reciclados, investimentos e pesquisas relacionados ao tema vêm sendo feitos em todo o mundo.

$\mathrm{Na}$ Inglaterra e na Bélgica, já se verifica a existência de subsídios financeiros nesta área, onde os mesmos são oferecidos para a compra de equipamentos, no caso dos ingleses, e para o investimento em companhias de reciclagem que processam resíduos de construção, no caso dos belgas (SCHNEIDER, 2003).

Em alguns países como Holanda, Alemanha, Dinamarca e a própria Bélgica, já há um conhecimento consolidado sobre o material e/ou normas avançadas para sua aplicação em vários serviços que podem variar em função de características particulares como ofertas de materiais de construção e de resíduos, disponibilidade de locais para disposição final ou rigor das normas relativas ao tipo de obra (LIMA, 1999). Na Bélgica, por exemplo, “foi desenvolvido um esquema de certificação voluntária para agregados reciclados, que é baseada em especificações técnicas estabelecidas pelas autoridades" (SCHNEIDER, 2003, p.20).

\subsection{Generalidades}

No Brasil, a Resolução CONAMA (2002) prescreve que os resíduos de construção que podem ser reutilizados ou reciclados para a produção de agregados são aqueles que se enquadram na chamada "Classe A". Esta categoria engloba os resíduos provenientes de: (a) construção, demolição, reformas e reparos de pavimentação e de outras obras de infra-estrutura, incluindo solos provenientes de terraplenagem; (b) construção, demolição, reformas e reparos de edificações tais como componentes cerâmicos (tijolos, blocos, telhas, placas de revestimento, etc.), argamassa e concreto; (c) processo de fabricação e/ou demolição de peças pré-moldadas em concreto (blocos, tubos, meios-fios, etc.) produzidas nos canteiros de obras.

Ainda de acordo com a Resolução CONAMA (2002), os demais resíduos de construção civil (Classes B, C e D), não são passíveis de reciclagem para a produção 
de agregados. Os resíduos de Classe B são materiais recicláveis, mas para outras finalidades, dos quais fazem parte "plásticos, papel/papelão, metais, vidros, madeiras e outros". Os de Classe C "são os resíduos para os quais não foram desenvolvidas tecnologias ou aplicações economicamente viáveis que permitam a sua reciclagem/recuperação, tais como os produtos oriundos do gesso". Já os de Classe D "são os resíduos perigosos oriundos do processo de construção, tais como: tintas, solventes, óleos e outros, ou aqueles contaminados oriundos de demolições, reformas e reparos de clínicas radiológicas, instalações industriais e outros".

Segundo Bodi et al. (1995), aproximadamente $80 \%$ de todo o resíduo de construção gerado é passível de reciclagem. Já de acordo com o ALT-MAT (1999), de todo o resíduo produzido, até $90 \%$ é constituído de materiais "duros", que podem se tornar agregados.

Os agregados reciclados têm a finalidade de substituir parcialmente ou totalmente o material natural empregado. Segundo a UTS (1999), as maiores diferenças verificadas entre os reciclados e os naturais podem ser resumidas a: (a) forma do grão e textura superficial, que no material reciclado tendem a ser mais irregulares; (b) densidade, que normalmente é menor nos agregados reciclados devido à sua alta porosidade; e (c) absorção de água, que é a diferença mais marcante entre os dois materiais, em se tratando de propriedades físicas.

De forma geral, os números relacionados à reciclagem no Brasil ainda são pouco significativos, pois equivalem a menos de $5 \%$ dos resíduos de construção gerados ${ }^{(3)}$. Em Belo Horizonte (MG), onde atualmente há grande atividade no setor, as duas estações de reciclagem municipais reciclam juntas em torno de $25 \%$ do resíduo de construção coletado, ou 350 toneladas por $\operatorname{dia}^{(4)}$.

(3) Segundo Luis Ciocchi, a partir de artigo publicado em $<$ www.piniweb.com.br $>$. CIOCCHI, L. Reciclagem de concreto. 16 de out. 2003. Disponível em: $<$ http://www.engepara.com.br $>$. Acesso em: 03 de jan. 2005.

(4) Dados do ano 2000, segundo a Prefeitura de Belo Horizonte. PREFEITURA DE BELO HORIZONTE. Reciclagem do entulho da construção civil. Disponível em: $<$ http://www.pbh.gov.br/siga/limpeza/entulho.htm $>$. Acesso em: 28 de mar. 2005. 
Nos Estados Unidos, a taxa de reciclagem de resíduos de construção no ano de 1996 ficou aproximadamente entre 20 e $30 \%$ (EPA, 1998).

Em alguns outros lugares do mundo, a reciclagem destes materiais atinge números expressivos, como no caso da cidade de Sidney, na Austrália, onde $80 \%$ dos resíduos de demolição são reciclados (UTS, 1999), e também da Holanda, que recicla ou reutiliza 90\% dos seus resíduos de construção, como aponta a Tabela 3.1, que relata as porcentagens reutilizadas ou recicladas destes materiais em países da União Européia, segundo a EC (1999).

Tabela 3.1: Porcentagem reutilizada ou reciclada em países da União Européia (EC, 1999)

\begin{tabular}{|c|c|}
\hline \multicolumn{1}{|c|}{ País } & $\begin{array}{c}\text { Porcentagem } \\
\text { reutilizada ou reciclada } \\
{[\%]}\end{array}$ \\
\hline Holanda & 90 \\
\hline Bélgica & 87 \\
\hline Dinamarca & 81 \\
\hline Finlândia & 45 \\
\hline Reino Unido & 45 \\
\hline Áustria & 41 \\
\hline Suécia & 21 \\
\hline Alemanha & 17 \\
\hline França & 15 \\
\hline Itália & 9 \\
\hline Espanha & $<5$ \\
\hline Grécia & $<5$ \\
\hline Irlanda & $<5$ \\
\hline Portugal & $<5$ \\
\hline \hline
\end{tabular}

É possível notar na Tabela 3.1 uma discrepância dos números relacionados à reciclagem ou reutilização de resíduos entre diferentes países da Comunidade Européia: Holanda, Bélgica e Dinamarca realizam amplamente estes processos, enquanto que Espanha, Grécia, Irlanda e Portugal não os fazem da mesma forma.

Ao se confrontar os números da Tabela 3.1 com aqueles apontados na Tabela 2.1 (que apresenta a geração de resíduos de construção em diversos países da Europa), é 
possível observar que, embora a Alemanha seja o maior gerador de resíduos de construção dentre as nações listadas - 3.658kg/ano per capita - sua porcentagem de reutilização ou reciclagem é baixa - 17\% - quando comparada com a da Bélgica, que é o segundo país em quantidade produzida - 3.408kg/ano per capita - e em reutilização ou reciclagem $-87 \%$.

A desigualdade de números referentes à reutilização ou reciclagem em diferentes países pode ocorrer em função de legislações vigentes (SCHNEIDER, 2003; UTS, 1999), grau de desenvolvimento local, disponibilidade de recursos naturais (O’MAHONY e MILLIGAN, 1991; LIM et al., 2001), ou ainda de custo do processo ou transporte.

$\mathrm{Na}$ Holanda, o uso de materiais reciclados é amplamente promovido pelas autoridades e indústrias do país, principalmente em função do custo de disposição final de resíduos e das limitações impostas à extração de materiais naturais (HENDRICKS e JANSSEN, 2001).

Em Portugal, o baixo índice de reutilização ou reciclagem, equivalente a menos de $5 \%$, provavelmente se deva à não aceitação de agregados reciclados de resíduos de construção pelas maiores autoridades do setor rodoviário português (EC, 1999).

Na Itália, a quantidade reutilizada ou reciclada de 9\% também não é significativa, mas isto pode ocorrer devido à cultura local de se restaurar ao invés de se demolir (COSTA e URSELLA, 2003; EC, 1999).

De qualquer forma, o uso de materiais alternativos deve aumentar consideravelmente no futuro em virtude de legislações ambientais mais severas e da escassez de agregados naturais (ALT-MAT, 1999).

\subsection{Processo de reciclagem}

Segundo Ângulo et al. (2003), a reciclagem de resíduos de construção é, de forma simplificada, um beneficiamento mineral. 
Em linhas gerais, este processo compreende um conjunto de operações unitárias que podem ser divididas em: (a) concentração; (b) cominuição; (c) peneiramento; e (d) auxiliares (LUZ et al., 2004; CHAVES, 2002).

\section{a) Operação de concentração}

Segundo Luz et al. (2004), os resíduos de construção são compostos por componentes minerais misturados com outros materiais como madeira, metais, restos de tintas e esmaltes, e gesso. Sendo assim, para ser utilizado em diversas finalidades como obras rodoviárias, o resíduo deve ser submetido à retirada das substâncias estranhas à fração mineral.

A operação de concentração resume-se à separação dos diferentes componentes do resíduo de construção por processos como catação (Figura 3.1) ou separação magnética (Figura 3.2), podendo ser feita antes e/ou depois da operação de redução. Como forma de facilitar a reciclagem destes materiais, a triagem de alguns componentes do resíduo no próprio local de geração já é exigida em alguns países da Europa e no Japão (SCHNEIDER, 2003).

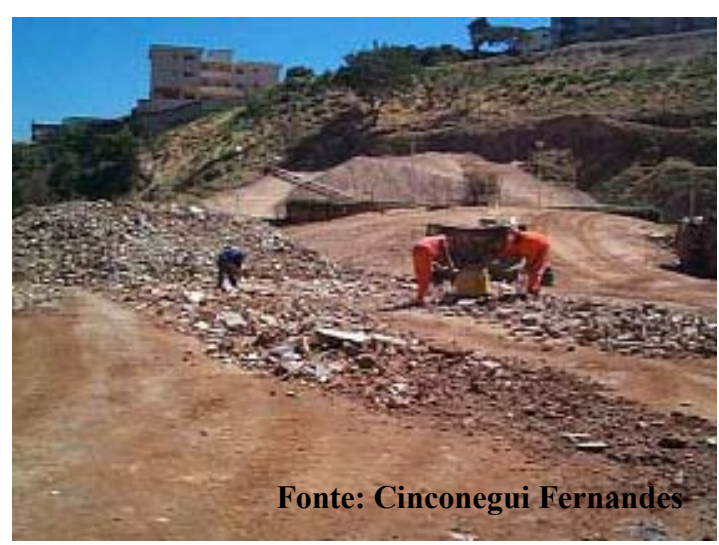

Figura 3.1: Catação realizada em recicladora de Belo Horizonte (MG) foto retirada de Fernandes (2004)

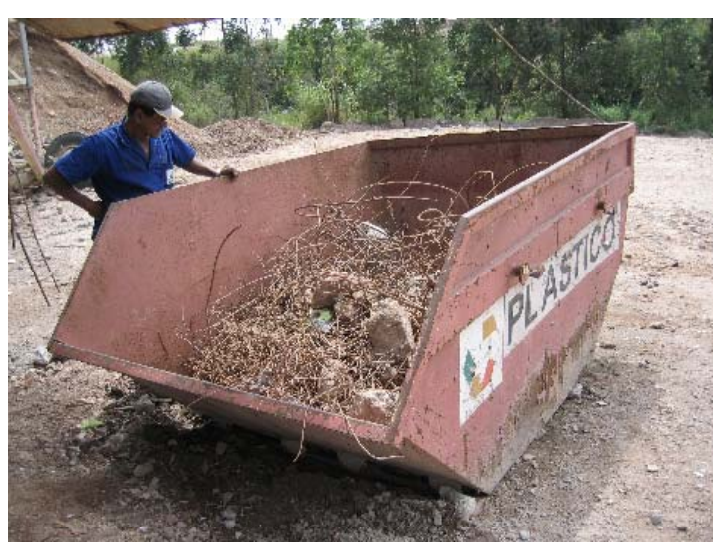

Figura 3.2: Material separado magneticamente em recicladora de São Paulo (SP)

\section{b) Operação de cominuição}


A operação de cominuição, comumente chamada de britagem, consiste em reduzir as dimensões do material para adequar o tamanho dos grãos à sua finalidade ou às operações subseqüentes (ÂNGULO et al., 2003; CHAVES, 2002; LUZ et al., 2004). Após a cominuição, os grãos tornam-se mais resistentes à compressão, se comparados ao resíduo bruto, uma vez que a fragmentação se dá no plano de menor resistência do material. Além disso, são formadas frações mais finas que favorecem o embricamento das partículas maiores (BODI et al., 1995).

A britagem pode ser feita por diferentes tipos de equipamentos, sendo estes os mesmos ou uma adaptação daqueles utilizados em mineração. O tipo de britagem é capaz de influenciar algumas características dos agregados reciclados como graduação, forma e resistência dos grãos (LIMA, 1999).

Durante a pesquisa bibliográfica, verificou-se que na produção de agregados reciclados tem-se feito uso de britagem primária e algumas vezes de secundária, que consistem em submeter o material ao processo de cominuição uma ou mais vezes, respectivamente. Tem-se feito uso de britadores de impacto, de mandíbula ou ainda de moinho de martelo (NUNES, 2004).

O britador de impacto é um dos tipos mais usados em recicladoras (LIMA, 1999) e pode ser empregado tanto em britagem primária quanto secundária. Hansen (1992) apud Lima (1999) afirma que este é o equipamento mais adequado à produção de agregados reciclados para uso em pavimentação, em função da granulometria apresentada. Neste tipo de britador, a fragmentação é feita pela colisão do material em placas fixas de impacto (LUZ et al., 2004). Dentre as principais características deste equipamento tem-se a significativa redução das dimensões do material, a produção de grãos mais cúbicos e de maior quantidade de finos em comparação a britadores de outros tipos (CHAVES e PERES, 2003).

Já o britador de mandíbula, cuja cominuição do material se dá por compressão, é geralmente utilizado como britador primário por gerar maior quantidade de grãos

${ }^{(5)}$ HANSEN, T.C. Recycling of demolished concrete and masonry. London: E\&FN Spon, 1992. 
graúdos (CHAVES e PERES, 2003; LIMA 1999), havendo em geral a necessidade de britagem secundária (LIMA, 1999). Como o uso de britador de mandíbula é adequado para materiais abrasivos (LUZ et al., 2004), o mesmo é indicado para a produção de agregados reciclados, que apresenta desgaste relativamente alto (como será visto no item 5.4.5) em comparação a outros materiais.

O moinho de martelo, por sua vez, é um equipamento onde a quebra do material se dá parte por impacto e parte por atrito. Dentre algumas características deste tipo de britador verifica-se a produção de grãos cúbicos e de grande quantidade de finos. E, diferentemente do britador de mandíbula, o moinho de martelo não é indicado para a cominuição de materiais abrasivos (CHAVES e PERES, 2003).

A Figura 3.3 ilustra o lançamento de resíduos de construção no britador de impacto da recicladora de Estoril em Belo Horizonte (MG). Já a Figura 3.4 apresenta a vista de um britador primário, do tipo mandíbula, pertencente a uma usina de reciclagem particular localizada em Jundiaí (no interior do estado de São Paulo).

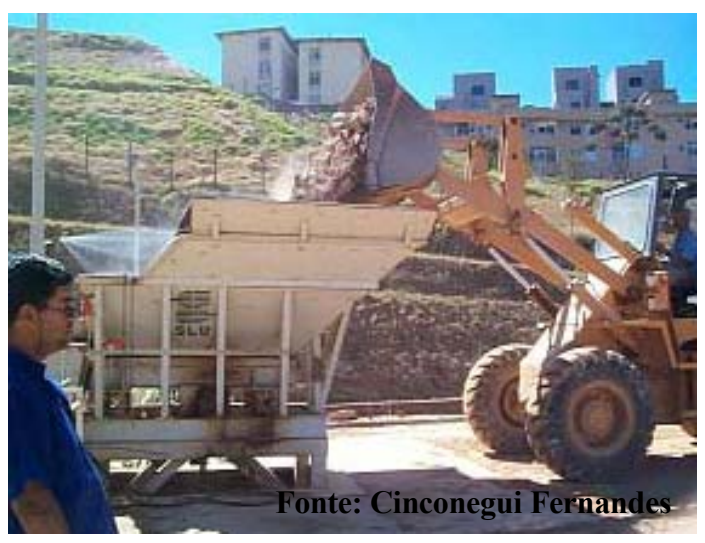

Figura 3.3: Lançamento de resíduo de construção no britador, em Belo Horizonte $(\mathrm{MG})$ - foto retirada de Fernandes (2004)

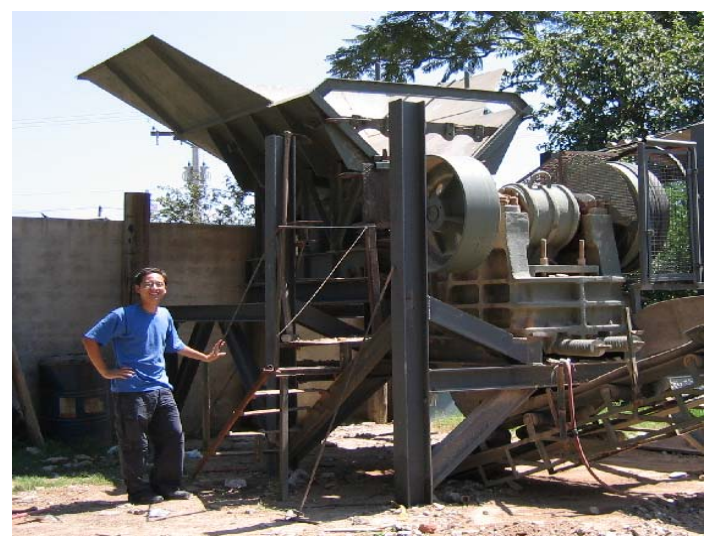

Figura 3.4: Vista de britador primário, em Jundiaí (SP)

\section{c) Operação de peneiramento}

A operação de peneiramento consiste em selecionar granulometricamente os grãos, passando-os por peneiras. 
A Figura 3.5 e a Figura 3.6 apresentam, respectivamente, o peneirador e a separação dos agregados reciclados em diferentes frações granulométricas da usina recicladora de Jundiaí (SP) citada no município de Jundiaí.

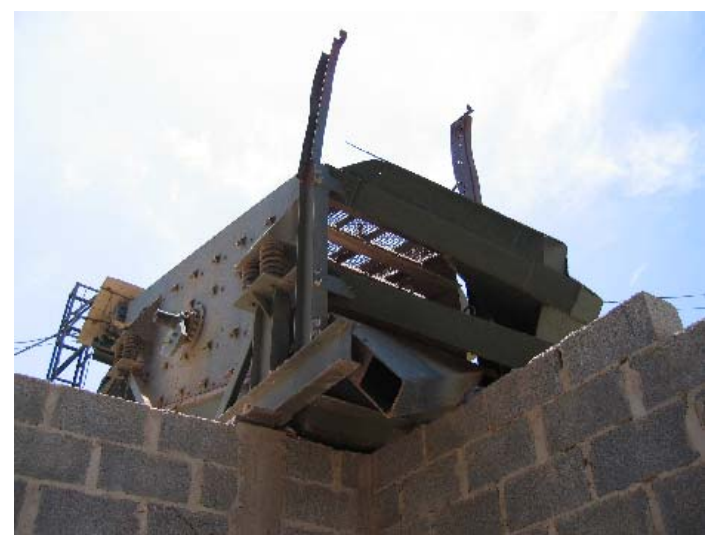

Figura 3.5: Vista inferior do peneirador, em Jundiaí (SP)

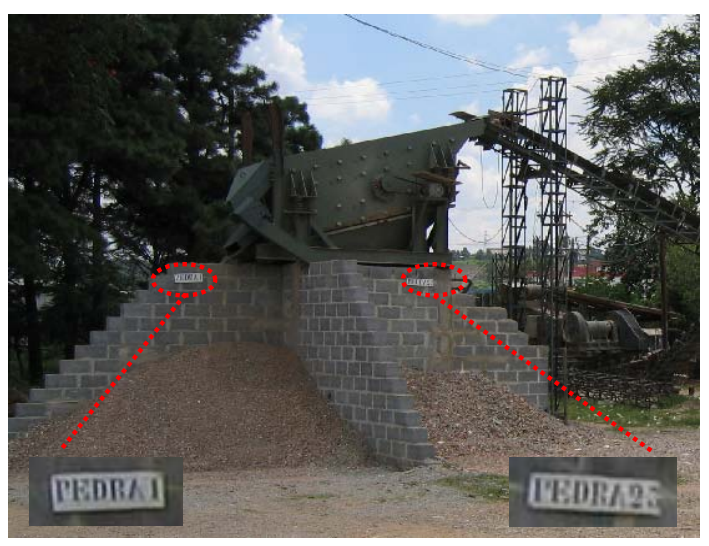

Figura 3.6: Separação conforme granulometria, em Jundiaí (SP)

A operação de peneiramento pode ser suprimida do processo de reciclagem nos casos em que haja interesse por material sem classificação granulométrica, sendo este comumente denominado como brita corrida.

\section{d) Operações auxiliares}

As operações auxiliares englobam procedimentos que visam dar assistência ao processo de reciclagem como, por exemplo, o uso de esteiras transportadoras e de sistemas nebulizadores; a Figura 3.7 e a Figura 3.8 ilustram estes procedimentos na usina recicladora de Estoril, em Belo Horizonte (MG). 


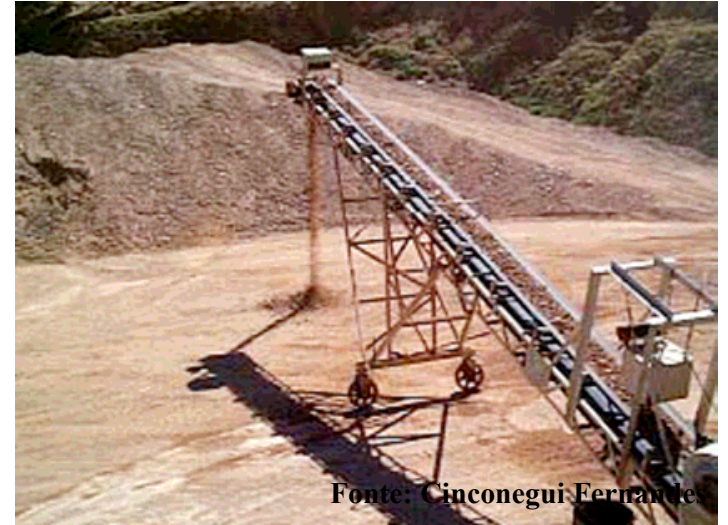

Figura 3.7: Agregado reciclado em esteira transportadora com eletroímã - foto retirada de Fernandes (2004)

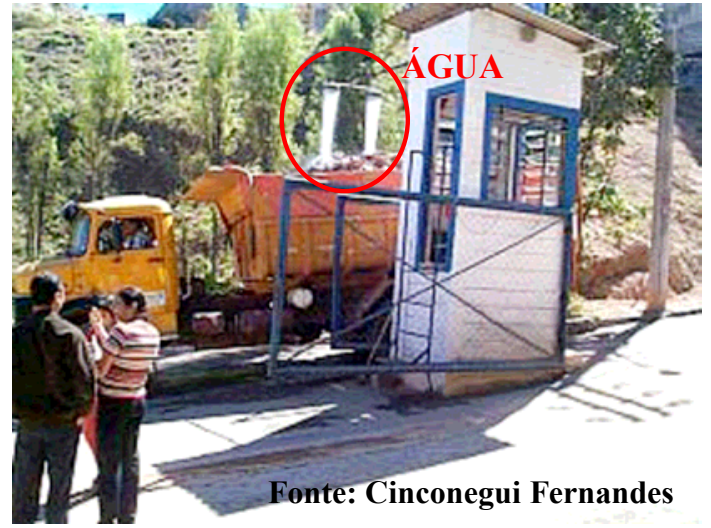

Figura 3.8: Molhagem do resíduo no caminhão, ao chegar na recicladora - foto retirada de Fernandes (2004), com modificações

O processo de reciclagem pode produzir diferentes tipos de agregados. Na Holanda, segundo Hendricks e Janssen (2001), são gerados agregados reciclados de concreto, alvenaria e misto para a utilização em sub-base de vias. No Brasil, tem-se verificado a produção de agregados reciclados dos tipos concreto (às vezes denominado como cinza ou branco, e composto basicamente de concreto e argamassa) e misto (também chamado de vermelho, cuja composição inclui diversos materiais pertencentes à Classe A da Resolução CONAMA de 2002).

Ângulo et al. (2003) estudaram agregados reciclados da usina recicladora da PMSP classificados como cinza e vermelho e verificaram que ambos apresentaram características físicas similares. Estes pesquisadores chegaram à conclusão de que a classificação dos agregados reciclados de acordo com a cor é pouco precisa.

\subsection{Possíveis empregos para o agregado reciclado}

Os agregados reciclados podem ser utilizados em diversos serviços de engenharia como camadas drenantes (com ausência de finos), lastro para assentamento de tubos ou de guias, envelopamento de galerias e estabilização de solos expansíveis ou com baixa capacidade de suporte (BRITO FILHO, 1999). Na Austrália, por exemplo, é comum se misturar agregados reciclados de concreto com quantidades limitadas de tijolos britados e solo para a obtenção de um produto reciclado considerado adequado para uso em pavimentação (UTS, 1999). 
Ademais, os agregados reciclados podem ser utilizados na produção de concreto e argamassa para diferentes fins como contra-pisos e componentes para alvenaria e infra-estrutura urbana como blocos, briquetes, meios-fios (LIMA, 1999). De acordo com Levy (2001), diversas obras em concreto produzidas com agregados reciclados foram executadas na Comunidade Européia; tem-se como exemplos a construção de uma laje submersa de $2.000 \mathrm{~m}^{3}$ em uma eclusa holandesa localizada na Hidrovia de Haandrick em 1988, e de toda a estrutura de um centro de operações de tratamento de água na Inglaterra, entre 1999 e 2000, em que foi empregado um volume de $4.000 \mathrm{~m}^{3}$ de concreto.

Os agregados reciclados também podem ser empregados em regularização e cascalhamento de ruas de terra, sendo vantajosos tecnicamente neste tipo de situação em relação às britas corridas comuns em virtude de sua coesão proveniente de reações pozolânicas que o tornam menos erodíveis (BRITO FILHO, 1999).

Além de todas as possibilidades de uso já citadas, os agregados reciclados de resíduos de construção podem ser empregados em camadas de base, sub-base ou reforço do subleito de pavimentos, cujo tema é escopo deste trabalho. Luz et al. (2004) mencionam que o agregado reciclado tem "boa aceitação no mercado de materiais para obras rodoviárias" (p. 711). Tem-se como exemplo deste tipo de aplicação a execução do trecho que constitui o acesso do novo campus da Universidade de São Paulo, denominado USP-Leste. Esta obra contou com a construção de base e sub-base, que totalizaram $25 \mathrm{~cm}$ de espessura ao longo de um trecho de aproximadamente $100 \mathrm{~m}$. A segunda fase das obras, a ser iniciada ainda em 2005, compreende a pavimentação de uma área de $33.000 \mathrm{~m}^{2}$ empregando agregado reciclado de resíduo de construção como material também de base e sub-base.

\subsection{Usina recicladora da PMSP}

$\mathrm{O}$ agregado reciclado estudado nesta pesquisa foi coletado na usina de reciclagem da PMSP, localizada no bairro de Itaquera, na zona leste da capital (Figura 3.9). Esta 
recicladora tem capacidade nominal de produção de 100 toneladas por hora e atualmente encontra-se paralisada ${ }^{(6)}$.

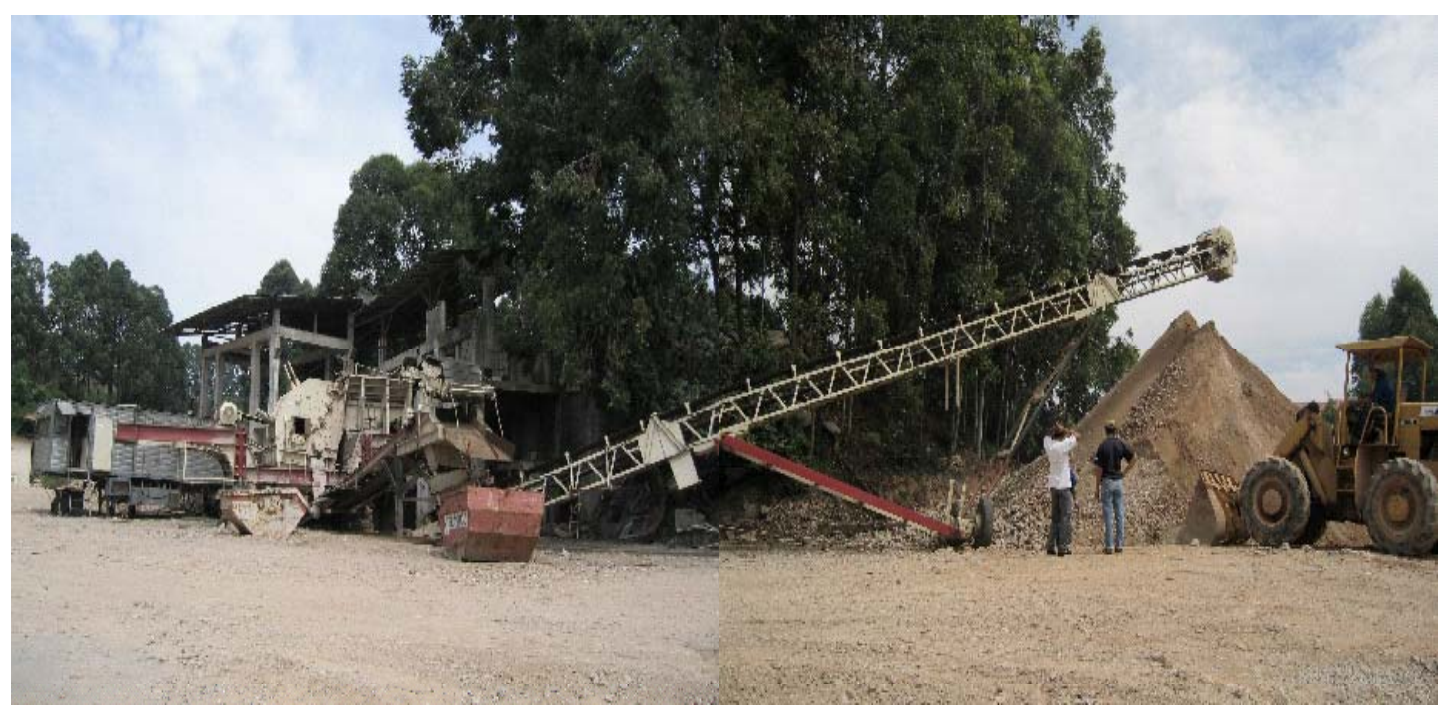

Figura 3.9: Vista da usina recicladora da PMSP

Ao chegar à recicladora, o resíduo de construção era separado em material cinza ou vermelho (Figura 3.10 e Figura 3.11).

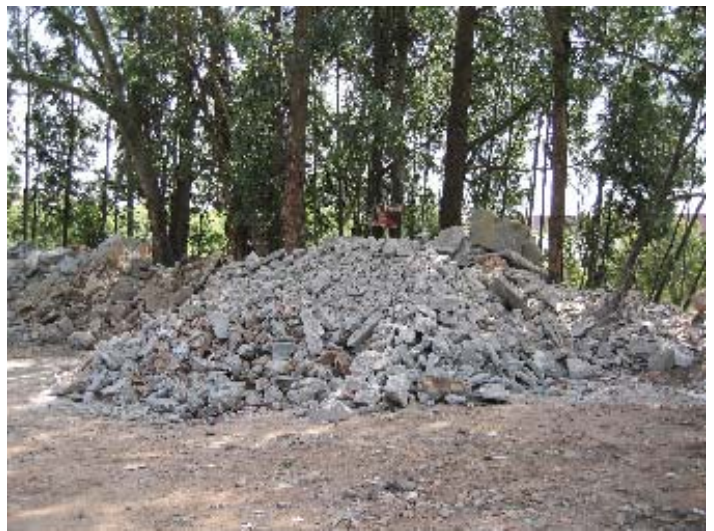

Figura 3.10: Resíduo cinza antes da reciclagem

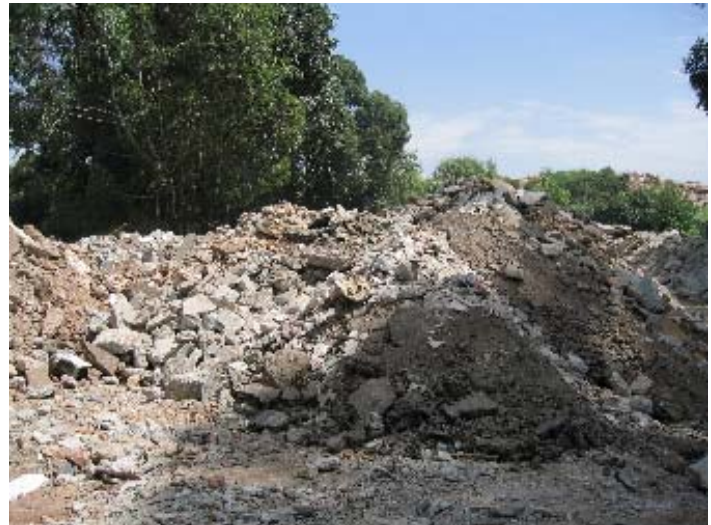

Figura 3.11: Resíduo vermelho antes da reciclagem

Na usina de reciclagem da PMSP, somente o produto de resíduo cinza vinha sendo classificado granulometricamente (Figura 3.12) e empregado na produção de

\footnotetext{
(6) PAPAZISSIS, V. C. Informação sobre a recicladora da PMSP. [mensagem pessoal]. Mensagem

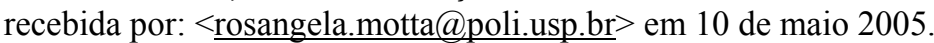


concreto. Já o material vermelho destinava-se à produção de brita corrida (Figura 3.13) para aplicação em obras de pavimentação (este foi o material coletado para os experimentos desta pesquisa).
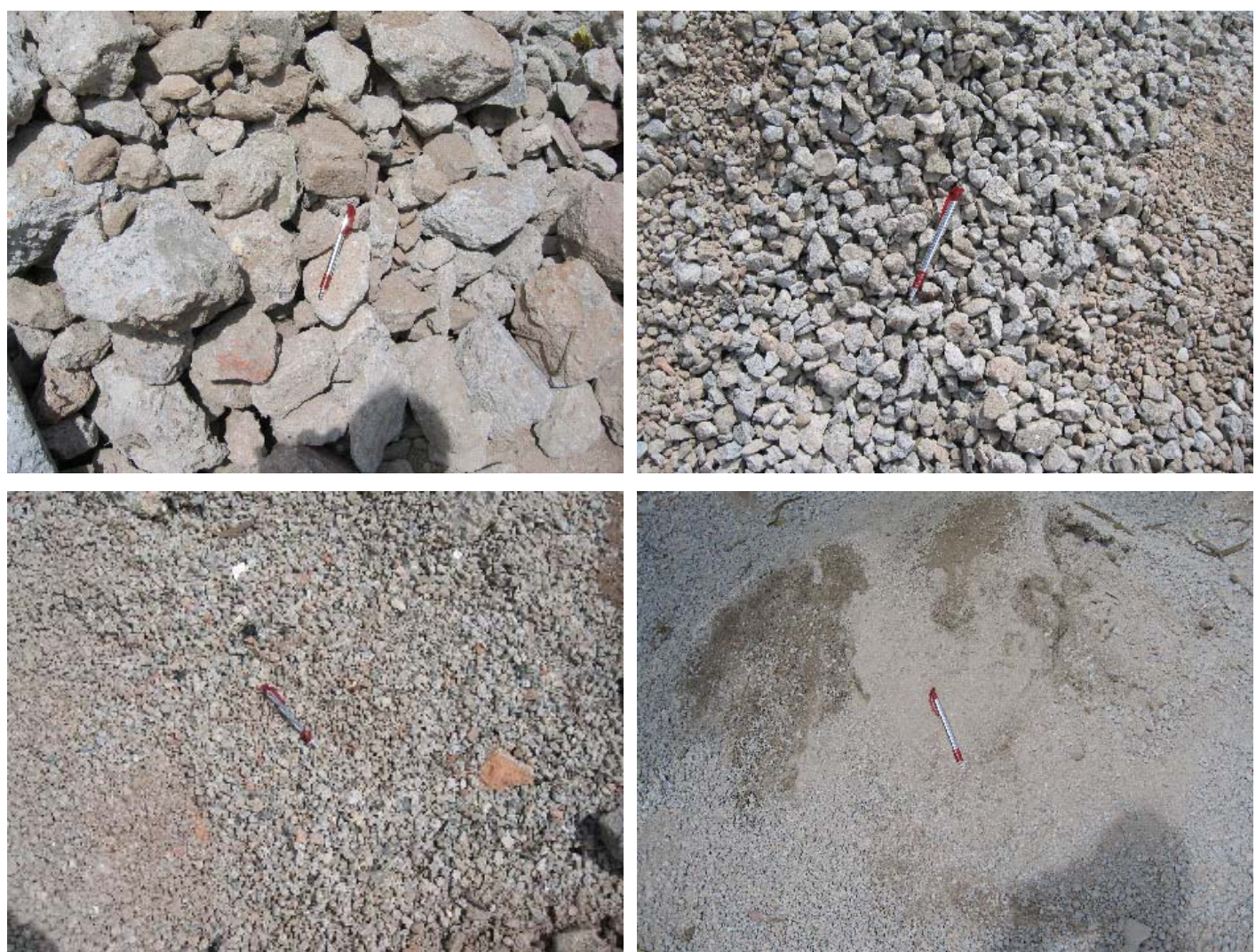

Figura 3.12: Agregados reciclados de concreto classificados granulometricamente

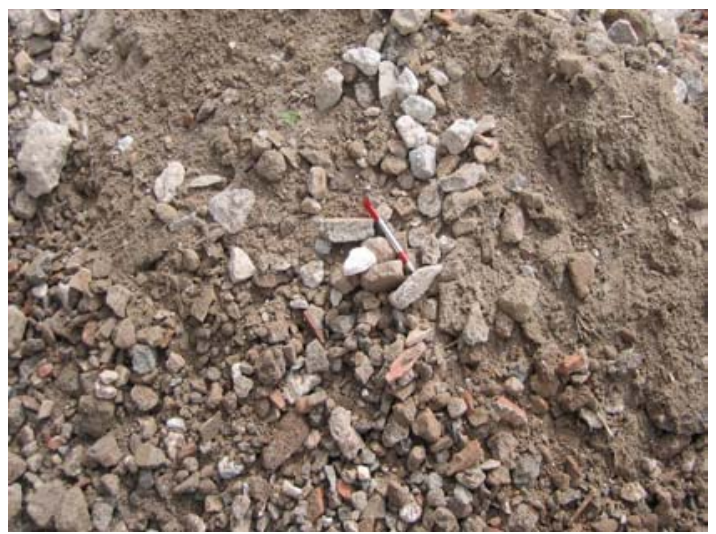

Figura 3.13: Agregado reciclado tipo brita corrida 
A Figura 3.14 e a Figura 3.15 apresentam uma vista do britador de impacto e do conjunto de peneiras da usina de reciclagem da PMSP.

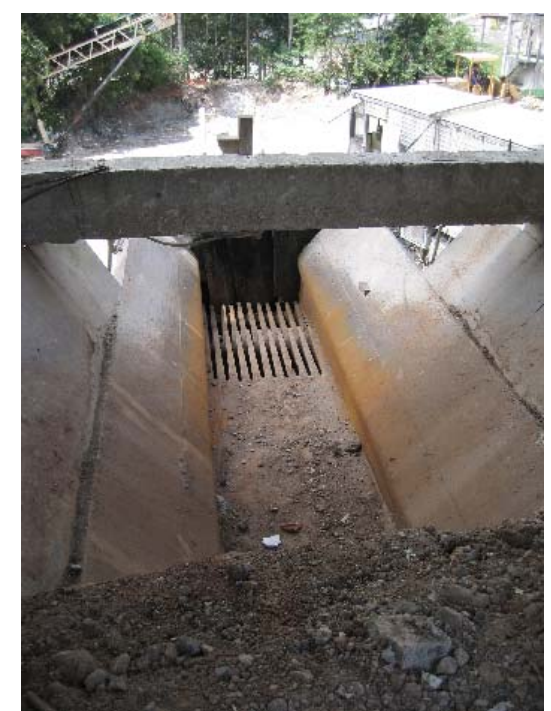

Figura 3.14: Vista do britador de impacto da recicladora da PMSP

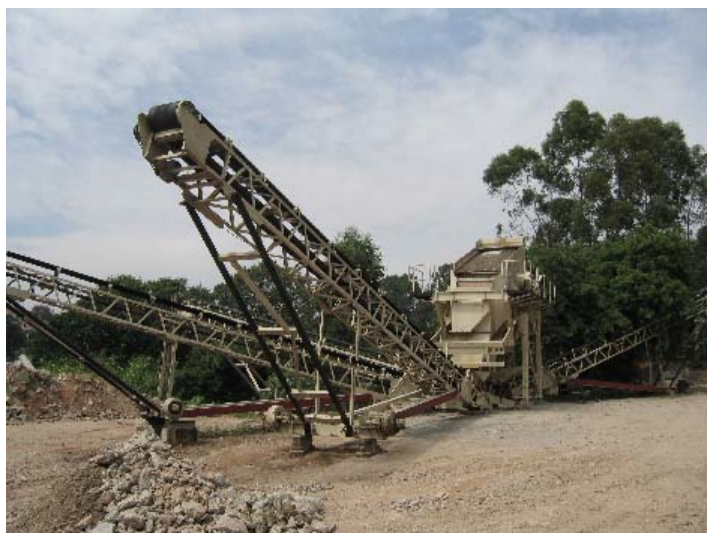

Figura 3.15: Vista do peneirador mecânico da usina de reciclagem da PMSP, com aberturas de peneiras de $4,8 \mathrm{~mm}, 20 \mathrm{~mm}$ e $40 \mathrm{~mm}$

Em termos de preços praticados pela PMSP (de acordo com tabela vigente em janeiro de 2005), a Tabela 3.2 apresenta um comparativo entre os valores do $\mathrm{m}^{3}$ de uma base executada com agregados reciclados e de outros materiais convencionalmente utilizados em pavimentos.

Tabela 3.2: Preço de base de pavimento executada pela PMSP (janeiro de 2005) ${ }^{(7)}$

\begin{tabular}{|c|c|}
\hline Material empregado & $\begin{array}{c}\text { Preço } \\
{\left[\mathbf{R} \$ \mathbf{m}^{\mathbf{3}}\right]}\end{array}$ \\
\hline Brita graduada & 52,74 \\
\hline Brita corrida comum & 45,03 \\
\hline Agregado reciclado de resíduo sólido da construção civil & $43,50^{(\mathrm{e})}$ \\
\hline
\end{tabular}

(e) Não é especificado se o preço se refere a agregados reciclados mistos ou de concreto. Sabe-se somente que o preço engloba o fornecimento de material e o serviço para uma distância de transporte de até $8,00 \mathrm{~km}$.

(7) PMSP - PREFEITURA DO MUNICÍPIO DE SÃO PAULO. São Paulo, 2005. Tabela de preços. Disponível em: $<\underline{\mathrm{http}}$ //portal.prefeitura.sp.gov.br/secretarias/infraestruturaurbana/tabela de precos/0001>. Acesso em: 03 jan 2005. 


\section{PAVIMENTAÇÃO COM AGREGADO RECICLADO}

\subsection{Pavimentação com agregado reciclado no mundo}

Muitos países têm especificações próprias no controle de produção e de aplicação de agregados reciclados em pavimentação.

$\mathrm{Na}$ Holanda, os requisitos para o uso de agregados em sub-base de pavimentos foram publicados em 1995 na Standard $R A W^{(8)}$ Road Specifications, e dá atenção a fatores como tamanho e forma dos grãos, além de quantidade de componentes indesejáveis (HENDRICKS e JANSSEN, 2001).

Na Itália, o emprego de agregados reciclados em pavimentação segue a especificação UNI Standard $10006^{(9)}$, que foca alguns pontos como ocorrência de materiais não pétreos, forma dos grãos e heterogeneidade (COSTA e URSELLA, 2003).

No Reino Unido, o Departamento de Transporte incluiu em Specification for Highway Works $^{(10)}$ o uso de concreto britado para uma série de aplicações, dentre elas em bases e sub-bases de pavimentos (POON, 1997).

$\mathrm{Na}$ Áustria, os agregados utilizados em obras rodoviárias devem atender, de forma geral, os requisitos da Austrian Standards for Transport and Road Construction (Richtlinien und Vorschriften für den Strassebau $-R V S)^{(11)}$. Não são verificadas diferenças em termos de métodos de ensaio ou requisitos para os materiais naturais ou reciclados, mas a qualidade dos resíduos reciclados é regulada por Guidelines for Recycled Building Materials ${ }^{(12)}$, que foram preparadas pela Austrian Quality Protection Association for Recycled Building Materials. A Áustria tem a melhor

(8) Standaard RAW bepalingen. Stichting Centrum voor Regelgeving en Onderzoek in de Grond-, Water-en Wegenbouw en de Verkeerstechniek. Ede: Stichting CROW, 1995.

${ }^{(9)}$ CNR UNI 10006. Costruzione e manutenzione delle strade-Tecnica di impiego delle terre. 2002.

(10) Specification for Highway Works. Department of Transport, London, England, 1986.

(11) RVS 8.01.60, 1990. Baustoffe - Industrielle Nebenprodukte und wiederverwendbare Baustoffe für den Straßenbau - Allgemeine Anforderungen - Richtlinien und Vorschriften für den Strassenbau, Wien; RVS 8.161, 1986. Baustoffe - Industrielle Nebenprodukte - LD-Schlacke - Richtlinien und Vorschriften für den Strassenbau, Wien; RVS 8.01.62, 1990. Baustoffe - Industrielle Nebenprodukte und wiederverwendbare Baustoffe für den Straßenbau - Hochofenschlacke - Richtlinien und Vorschriften für den Strassenbau, Wien.

${ }^{(12)}$ BRV Richtlinie für Recycling - Baustoffe (1992) 
experiência na reciclagem de pavimentos de concreto; os pavimentos antigos transformam-se em agregados na construção de novos pavimentos de concreto de cimento Portland (OECD, 1997 ${ }^{(13)}$ apud ALT-MAT, 1999).

Na Austrália, mais especificamente nas regiões de Nova Gales do Sul e Vitória, dentre as normas relacionadas ao uso de agregados reciclados de concreto em construção de sub-bases estão: RTA Q3051: Unbound and Modified Base and Subbase Materials for Surfaced Road Pavements ${ }^{(14)}$; AUS-SPEC \#2 Asset Owners Roadworks Specifications ${ }^{(15)}$ e VicRoads (Victoria) 820Q: Crushed Concrete for Subbase Pavement ${ }^{(16)}$. Embora nem todos os requisitos destas especificações sejam atendidos, são utilizadas grandes quantidades de agregados reciclados neste tipo de obra por razões econômicas (UTS, 1999).

Em termos de tipos aplicados à pavimentação, alguns países adotam o uso de agregados reciclados de concreto, como é o caso dos Estados Unidos (LIMA, 1999). O ALT-MAT (1999) cita que o emprego destes em pavimentos é bem estabelecido em bases granulares ou estabilizadas, e em pavimentos de concreto de cimento Portland, possuindo ainda potenciais aplicações em misturas de concreto asfáltico a quente e em tratamentos superficiais. Na União Européia, além dos agregados reciclados de concreto, são utilizadas em sub-base de vias também as frações derivadas de alvenaria (EC, 1999).

No que se refere às pesquisas relacionadas à aplicação de agregados reciclados em pavimentação, foi possível notar ao longo deste estudo que muitas delas vêm sendo realizadas em todo o mundo já há muitos anos. Tem-se como um interessante exemplo a união de alguns países europeus para a formação de um grupo chamado ALT-MAT (Alternative Materials in Road Construction) para analisar, em laboratório e em campo, materiais alternativos destinados a pavimentos. A pesquisa,

(13) OECD - ORGANIZATION FOR ECONOMIC CO-OPERATION AND DEVELOPMENT. Recycling strategies for road works. Paris: OECD, 1997.

(14) RTA QA Specification 3051, Unbound and Modified Base and Subbase Materials for Surface Road Pavements.

(15) Statewide Roads, AUS-SPEC \#2 Asset Owners Roadworks Specifications, Sydney, 1997.

(16) VicRoads Specification on Crushed Concrete for Subbase Pavement, Section 820Q. 
que teve duração de aproximadamente dois anos, concluiu, entre outras coisas, que os valores limites dos testes aplicados devem ser baseados em características locais como clima e experiência adquirida, e que o desempenho em campo foi, em alguns casos, melhor do que a previsão feita em laboratório.

\subsection{Pavimentação com agregado reciclado no Brasil}

\subsubsection{Algumas experiências práticas}

Bodi et al. (1995) citam que em muitas vias urbanas de São Paulo (SP), a população utilizou resíduos de construção como revestimento primário, a fim de minimizar a ocorrência de lama em períodos chuvosos ou poeira em períodos de estiagem e, apesar de não terem recebido uma pavimentação definitiva, estas vias passaram a requerer menores intervenções; verificou-se que houve uma progressão na estabilidade do subleito com a compactação do tráfego local e com a incidência de chuvas.

Baseando-se neste fato, em 1984 foi pavimentada a primeira via de São Paulo empregando agregados reciclados de resíduos de construção com acompanhamento tecnológico, por meio de parceria entre a PMSP e o IPT (Instituto de Pesquisas Tecnológicas) na execução e no acompanhamento da obra, respectivamente. Este logradouro, de nome Gervásio da Costa, localiza-se na zona oeste da cidade e é caracterizado por um baixo volume de tráfego. A Figura 4.1 ilustra o esquema estrutural deste pavimento, onde percebe-se que as camadas de reforço do subleito e sub-base foram construídas com agregados reciclados. Seu desempenho foi considerado altamente satisfatório na época (BODI et al., 1995). 


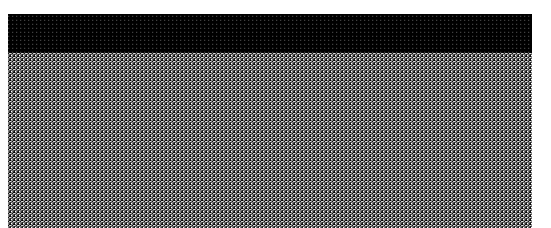

$3 \mathrm{~cm}$ de $\mathrm{PMF}^{(\mathrm{f})}$

$15 \mathrm{~cm}$ de brita corrida comum

$10 \mathrm{~cm}$ de entulho ${ }^{(\mathrm{g})}$

$10 \mathrm{~cm}$ de entulho ${ }^{(\mathrm{g})}$

$\mathrm{CBR}^{(\mathrm{h})}$ do subleito de $12 \%$

${ }^{(f)}$ Pré-misturado a frio

(g) Designação popular para o resíduo de construção e demolição

(h) California Bearing Ratio ou Índice de Suporte Califórnia

Figura 4.1: Esquema de pavimento da Rua Gervásio da Costa, segundo figura retirada de Bodi et al. (1995), com modificações

Em Belo Horizonte (MG), os agregados reciclados vêm sendo utilizados desde 1996 na execução de revestimento primário, reforço do subleito, sub-base e base de pavimentos (Figura 4.2), como nas avenidas Silva Lobo, Raja Gabaglia e Mário Werneck, além da Rua Adelina Amaral Pongelupe, cuja execução está ilustrada na Figura 4.3 ${ }^{(17)}$. De 1996 até julho de 2001 foram utilizadas quase 137.000 toneladas de material em 271 vias implantadas ou reconstruídas, em um total de $400 \mathrm{~km}$ de ruas, aproximadamente (DIAS, 2004). Os projetos foram baseados em dimensionamentos empíricos, a partir de cálculos que levaram em conta Índice de Suporte Califórnia e a experiência dos engenheiros do município (FERNANDES, 2004).

(17) PREFEITURA DE BELO HORIZONTE. Reciclagem do entulho da construção civil. Disponível em: $<$ http://www.pbh.gov.br/siga/limpeza/entulho.htm>. Acesso em: 28 de mar. 2005. 


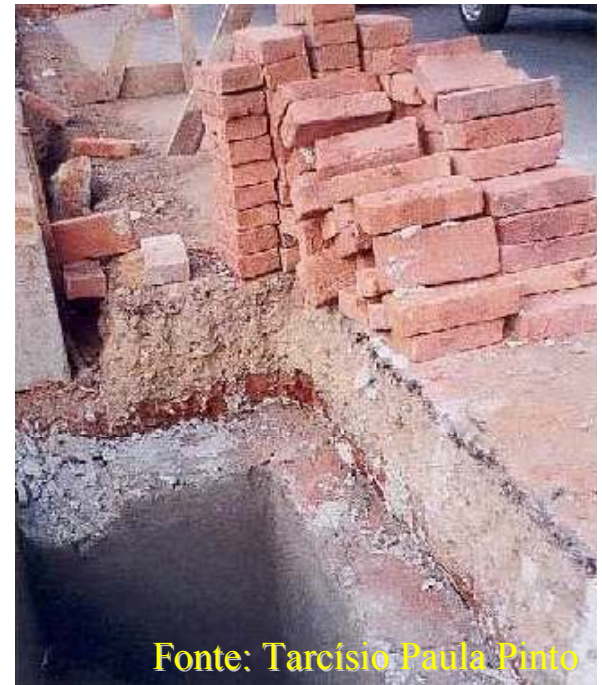

Figura 4.2: Corte do pavimento com base executada com RCD reciclado em Belo Horizonte, segundo foto retirada de Pinto (1999)

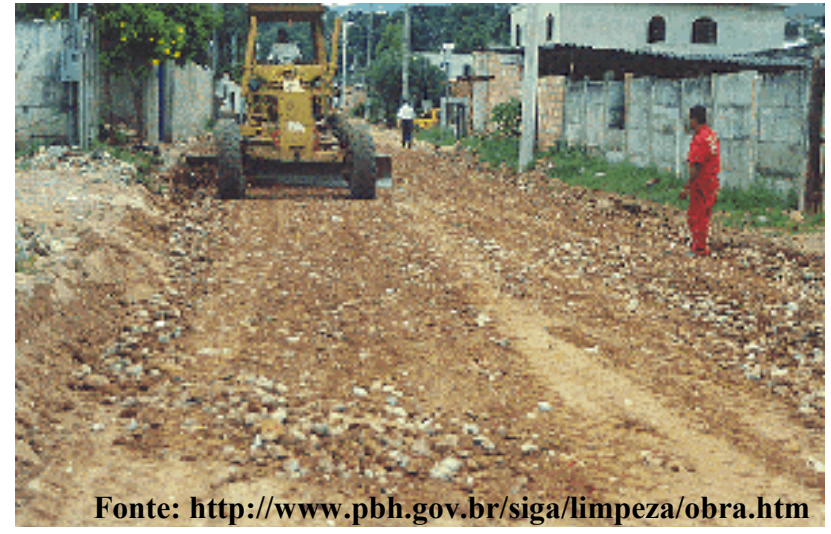

Figura 4.3: Execução da sub-base de pavimento com agregado reciclado na Rua Adelina Amaral Pongelupe em Belo Horizonte (MG)

\subsubsection{Normalização}

Na década de 90, deu-se início à instalação de usinas de reciclagem no Brasil, mas não havia normalização para o uso de agregados reciclados em pavimentação. Em março de 2002, a PMSP publicou no Diário Oficial do Município a sua própria especificação com o título de "Camadas de reforço do subleito, sub-base e base mista de pavimento com agregado reciclado de resíduos sólidos da construção civil”.

Como já citado, no ano de 2004 a ABNT publicou a norma para aplicação de agregados reciclados em pavimentação. A NBR 15115, que trata dos procedimentos 
para o emprego do material em pavimentos, teve seu texto baseado na norma paulistana citada no parágrafo anterior.

Segundo a NBR 15115 (2004), o agregado reciclado aplicável à pavimentação é o "material granular, obtido por meio de britagem ou beneficiamento mecânico, de resíduos de construção civil", pertencentes à Classe A da Resolução CONAMA (2002). O material deve atender a alguns requisitos como: (a) boa graduação granulométrica; (b) valores mínimos de ISC e de expansão (conforme o tipo de camada do pavimento); e (c) dimensão máxima característica de $63,5 \mathrm{~mm}$.

\subsubsection{Pesquisas realizadas}

No Brasil, dentre as pesquisas realizadas, verifica-se a existência de numerosos trabalhos no que se refere ao uso de agregado reciclado para confecção de concreto, mas poucos relacionados ao emprego do material em pavimentação. Algumas destas pesquisas serão citadas a seguir, e parte dos resultados alcançados nas mesmas será discutida ao longo do Capítulo 5, para comparação com os valores obtidos no presente estudo.

Bodi et al. (1995) analisaram três tipos de agregados reciclados de São Paulo (SP): branco, vermelho e misto. A pesquisa incluiu a análise da mistura de agregado reciclado misto com solo siltoso (saprolítico) e argiloso (com comportamento laterítico), sendo feitos ensaios de compactação e ISC. Os resultados foram considerados positivos.

Trichês e Kryckyj (1999) pesquisaram agregados reciclados de Florianópolis (SC) separados nas frações branca e vermelha e também misturados com solo arenosiltoso e argiloso. Foram realizados ensaios de peneiramento para obtenção da granulometria, além de compactação e ISC. Segundo os pesquisadores, os resultados obtidos demonstraram que o material se apresenta como uma excelente alternativa para o uso em camadas de reforço do subleito e sub-base, além de possuir potencial para ser empregado na redução de plasticidade do solo de fundação. 
Carneiro et al. (2001) estudaram agregados reciclados de Salvador (BA) nas frações graúda e miúda, além de suas misturas com solo laterítico e saprolítico em diferentes proporções. Os autores realizaram ensaios de caracterização física e mecânica, dentre os quais incluem-se análise granulométrica, abrasão "Los Angeles", compactação e ISC. Com base nos resultados obtidos, os pesquisadores concluíram que o agregado reciclado de Salvador, em ambas as frações, se apresentou como material adequado à aplicação em bases e sub-bases de pavimentos.

Ribeiro et al. (2002) avaliaram agregados reciclados brancos e vermelhos, além de sua mistura com solo tipo ML (segundo classificação no Sistema Unificado) ou A-75 (na classificação da HRB). A coleta se deu em Goiânia (GO), e a britagem foi feita em laboratório para adequação às faixas granulométricas especificadas pelo DNER. Foram realizados ensaios de compactação e também de ISC e, segundo os autores, verificou-se com os resultados obtidos que a utilização de agregados reciclados em pavimentação é tecnicamente viável.

Frota et al. (2003) analisaram agregados reciclados da cidade de Manaus (AM) como forma de substituir os seixos em misturas asfálticas, que são agregados convencionalmente empregados nesta finalidade e cuja exploração causa grande impacto ambiental. Foram realizados ensaios de caracterização do ligante asfáltico CAP-20 - e do agregado reciclado (isento de materiais cerâmicos e gesso), além de dosagem pelo método Marshall. Foram confeccionadas três misturas, sendo uma com seixo e outras duas com agregado reciclado em diferentes proporções $(50 \% \mathrm{e}$ $60 \%$ ), incluindo em todos os casos areia e também cimento Portland como fíler. Notou-se que as misturas com agregado reciclado necessitam de maior quantidade de ligante, o que já devia ser esperado, pois estes materiais apresentam maior porosidade que os convencionais; o teor ótimo de ligante observado para as misturas com seixo foi de 5,5\%, enquanto que para as outras duas misturas de agregado reciclado foi de $6,4 \%$ e $6,5 \%$ (respectivamente para as proporções de $50 \%$ e $60 \%$ ). Os autores concluíram que a aplicação de agregado reciclado em misturas asfálticas, em substituição ao seixo, é tecnicamente viável. No entanto, esta significativa diferença no teor de ligante se reflete em maiores custos, o que pode inibir a 
utilização de agregados reciclados para esta finalidade. Além disso, como será visto mais adiante no item 5.4.5, o agregado reciclado é muito suscetível à abrasão, e normalmente a aplicação de materiais com este tipo de característica em camadas de rolamento é evitada devido à maior facilidade com que o tráfego poderá desgastá-lo. De acordo com Hill et al. (2001), dada a intensidade de carregamento vivenciada pela superfície de uma estrutura de um pavimento, a aplicação de agregados reciclados deve ser feita nas camadas inferiores.

Fernandes (2004) pesquisou as características do agregado reciclado in natura de recicladoras do Rio de Janeiro (RJ) e Belo Horizonte (MG). A primeira usina de reciclagem forneceu material selecionado nas frações de britas 0 e 1, pedrisco e póde-pedra, sendo todas do tipo misto. Já a segunda cedeu agregados reciclados em forma de brita corrida dos tipos misto e concreto. O autor realizou ensaios de caracterização física como granulometria, abrasão "Los Angeles" e índice de forma, e ainda analisou o comportamento mecânico dos materiais citados perante ensaios de Módulo de Resiliência. Com os resultados obtidos, o pesquisador concluiu que o uso de agregados reciclados em pavimentação é "viável tecnicamente, economicamente motivador e ambientalmente benéfico", sendo "uma resposta à necessidade de crescimento sustentável” (p.97). 


\section{PROGRAMA EXPERIMENTAL}

O programa experimental deste trabalho analisa algumas características físicas e propriedades mecânicas do agregado reciclado de resíduo sólido da construção civil proveniente da usina de reciclagem da PMSP, por meio de ensaios de laboratório comumente empregados nas pesquisas relacionadas aos materiais convencionais de pavimentação, bem como outros testes complementares para melhor caracterização do agregado reciclado.

Cabe ressaltar que procedimentos e requisições de ensaios desenvolvidos para materiais naturais nem sempre podem ser apropriados para os alternativos (ALTMAT, 1999) devendo ser aprimorados para melhor representarem o comportamento destes últimos.

\subsection{Coleta de agregado reciclado}

Para os estudos laboratoriais foram coletadas na usina recicladora da PMSP cerca de 2,7 toneladas de agregado reciclado. A coleta se deu em um único dia, a partir da retirada de um único monte (Figura 5.1). Embora haja a possibilidade de variação de natureza constituinte e de distribuição granulométrica do material em um único monte produzido em um só dia, objetivou-se nesta pesquisa não introduzir mais uma variável relacionada à mudança significativa da constituição e da graduação do material analisado (a influência da variação dos materiais constituintes em suas propriedades mecânicas faz parte de um outro estudo que vem sendo desenvolvido no LTP-EPUSP). Portanto, procurou-se determinar as propriedades de um tipo único de agregado reciclado, compreendendo a variabilidade de suas características físicas e mecânicas com a umidade, energia de compactação, tempo de cura e adição de cal ou cimento Portland. Além disso, com estes dados, pode-se ter uma primeira avaliação que permita uma comparação do agregado reciclado com materiais convencionalmente adotados em obras de pavimentação.

O material foi conduzido ao LTP-EPUSP em sacos de 50kg (Figura 5.1), sendo o transporte feito por caminhão da Escola Politécnica (Figura 5.2 e Figura 5.3). 


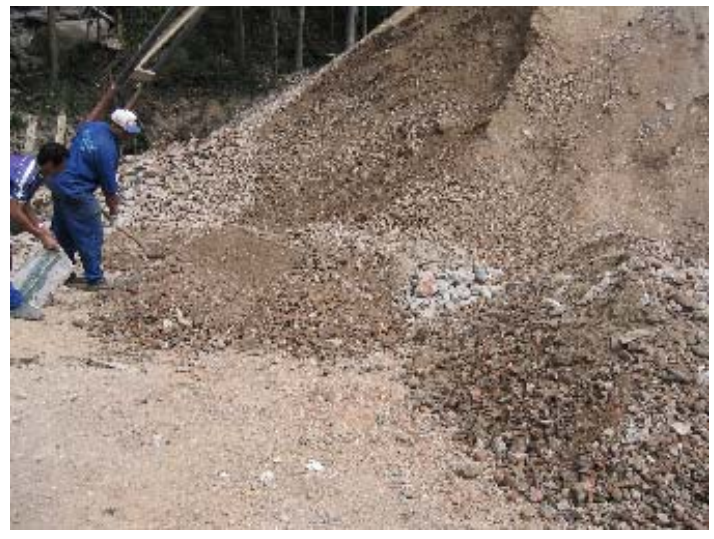

Figura 5.1: Coleta do agregado reciclado na usina da PMSP

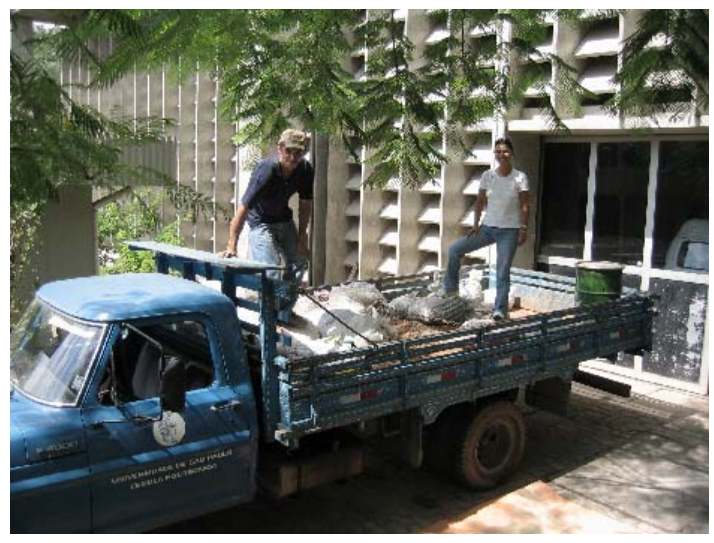

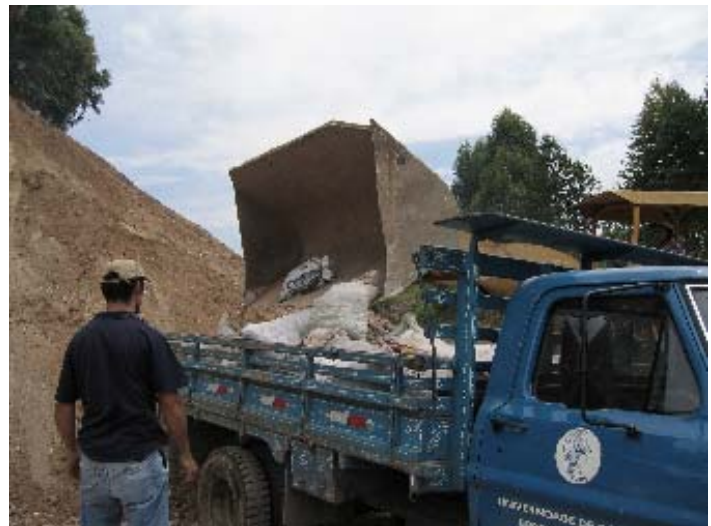

Figura 5.2: Disposição dos sacos no caminhão por meio de pá carregadeira

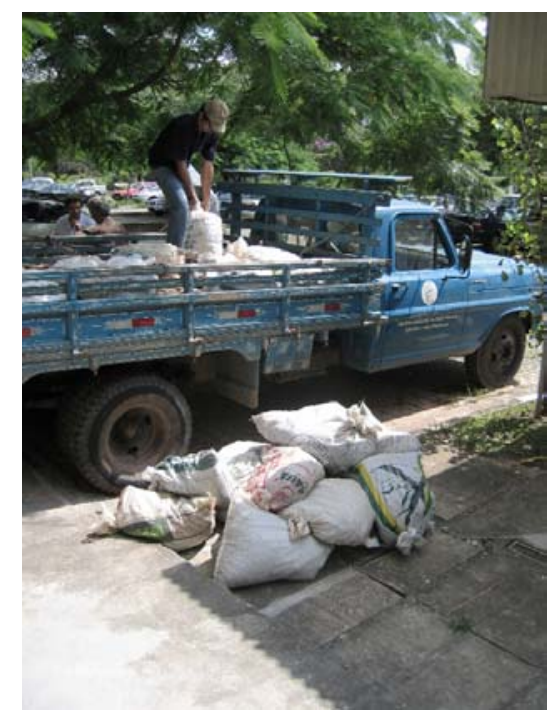

Figura 5.3: Chegada do caminhão e descarregamento das amostras no LTP-EPUSP

Em função do aparente excesso de umidade da amostra coletada, procedeu-se à sua secagem prévia. Para isto, as porções ensacadas foram dispostas lado a lado no chão do laboratório, em uma área coberta e, posteriormente, espalhadas para homogeneização (Figura 5.4). O material permaneceu sob esta condição durante seis dias, a fim de que sua umidade higroscópica fosse atingida. 

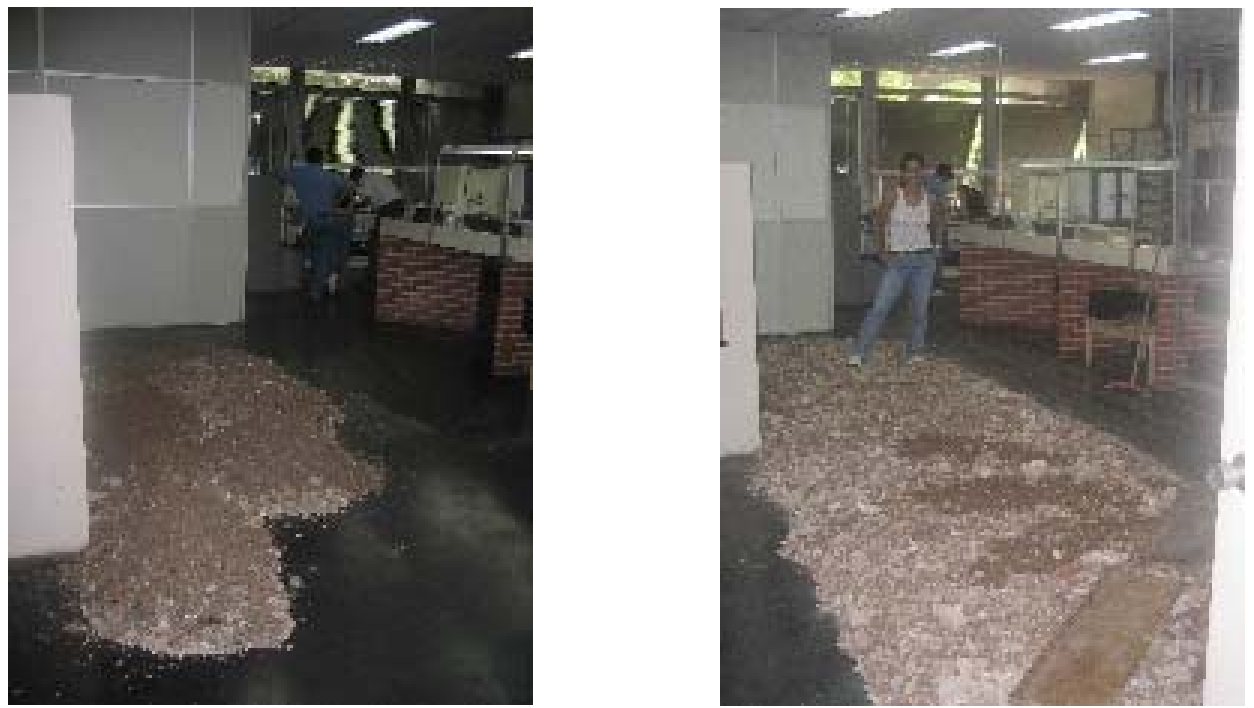

Figura 5.4: Disposição das porções ensacadas para secagem

\subsection{Homogeneização}

Durante o processo de secagem, todo o material foi cuidadosamente revolvido até que, visualmente, fosse alcançada uma aparência homogênea em relação à granulometria (Figura 5.5).

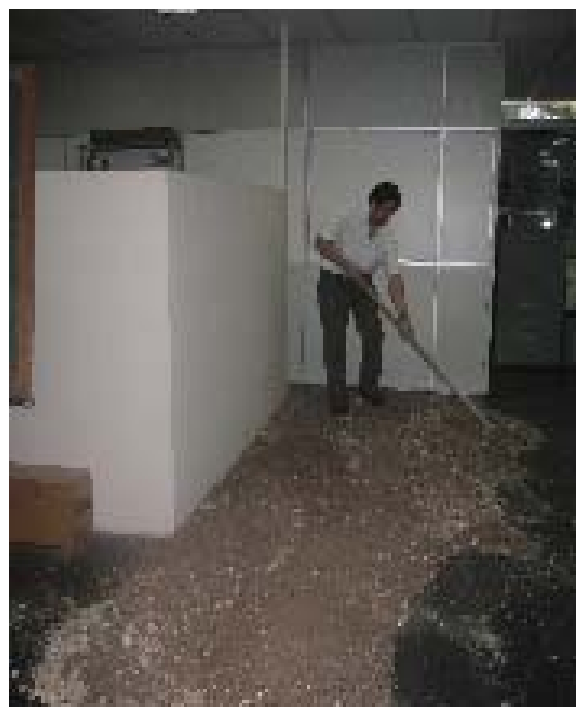

Figura 5.5: Revolvimento do material para homogeneização

\subsection{Amostragem}

Após o processo de secagem e homogeneização, o material foi separado em porções aproximadamente iguais de $12 \mathrm{~kg}$ a $13 \mathrm{~kg}$, sendo estas ensacadas com atenção para 
que não houvesse perda de finos. A Figura 5.6 ilustra o processo de fracionamento do material em porções representativas para estocagem das mesmas (Figura 5.7). Foi obtido um total de 225 porções, que foram consideradas, a partir de então, amostras representativas do agregado reciclado.

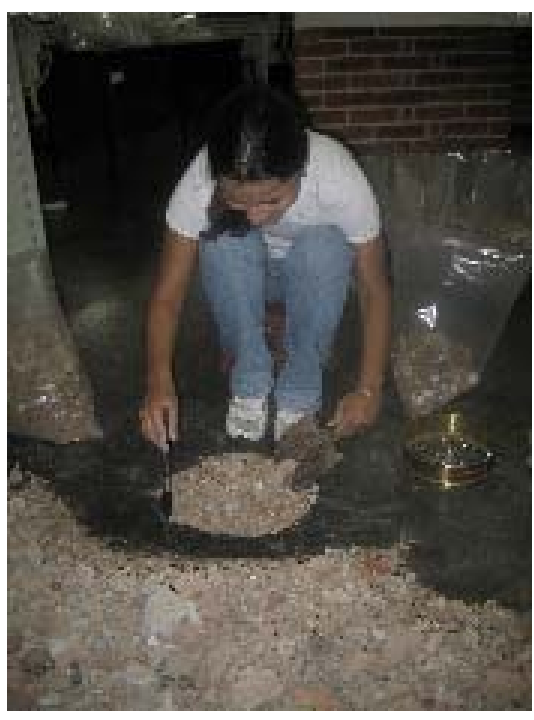

Figura 5.6: Separação do agregado reciclado em porções representativas

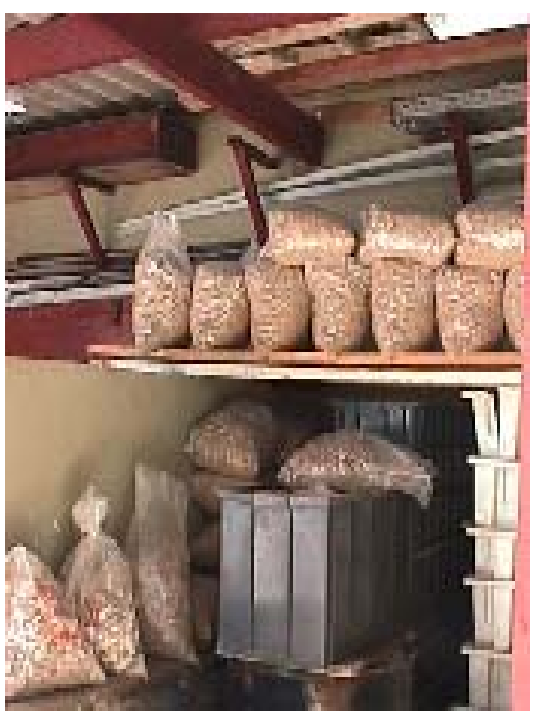

Figura 5.7: Material ensacado e estocado

Cabe ressaltar que para esta pesquisa foram empregados somente os grãos com dimensão característica igual ou inferior a $63,5 \mathrm{~mm}$, como especifica a NBR 15115 (2004). Os materiais com dimensões superiores correspondiam, de forma aproximada, a menos de $1 \%$ do total coletado.

\subsection{Caracterização física do agregado reciclado}

A caracterização física do agregado reciclado tem grande importância para o estudo da aplicação deste material em uma estrutura de pavimento, uma vez que suas propriedades físicas estão intimamente relacionadas à resistência que o mesmo apresentará quando submetido ao tráfego.

Nesta pesquisa, foram analisados os seguintes aspectos físicos do agregado reciclado:

(a) natureza dos materiais constituintes; (b) distribuição granulométrica; (c) absorção de água; (d) atividade pozolânica; (e) resistência ao desgaste; (f) forma dos grãos; e (g) teor de materiais indesejáveis. 


\subsubsection{Natureza dos materiais constituintes}

A composição do agregado reciclado desta pesquisa foi verificada por meio de catação e análise visual macroscópica.

Os grãos de uma amostra de cerca de $13 \mathrm{~kg}$ foram separados e agrupados conforme sua natureza, a fim de definir as porcentagens de cada tipo distinto de material de construção presente no agregado reciclado coletado.

Os grãos da fração com dimensão característica inferior a 4,76mm não foram separados em grupos em função da dificuldade de identificação de sua natureza a olho nu. Desta forma, este grupo de grãos passados na peneira $4,76 \mathrm{~mm}$, que inclui agregados miúdos (entre 4,76mm e $0,074 \mathrm{~mm}$ ) e finos (menores que $0,074 \mathrm{~mm}$ ), será denominado neste trabalho simplesmente como "material fino".

Os grupos formados no processo de separação de grãos foram: (a) concreto/argamassa (cimentíceos); (b) brita (materiais britados); (c) telha/tijolo (cerâmicos vermelhos); (d) piso/azulejo; (e) telha de amianto; e (f) material fino.

A Figura 5.8 apresenta a composição do agregado reciclado estudado, de acordo com as porcentagens em massa de cada grupo formado. 


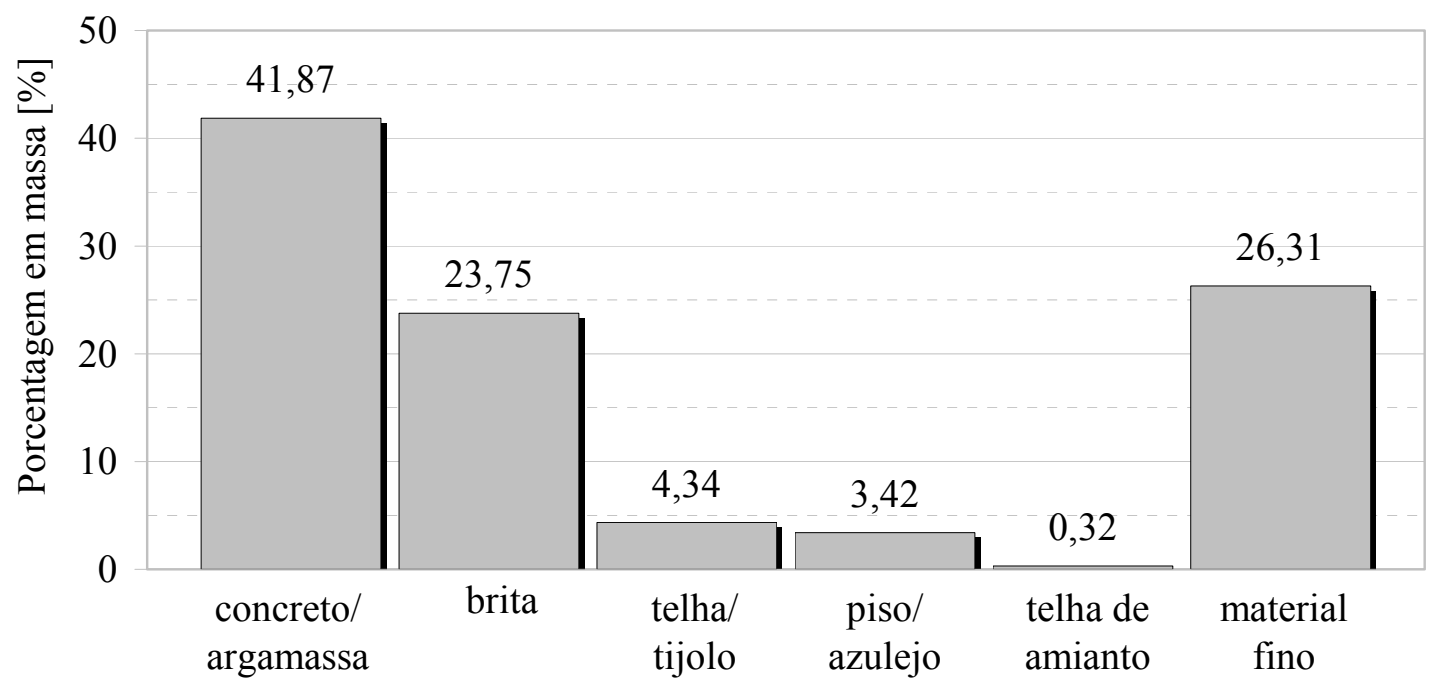

Figura 5.8: Composição do agregado reciclado estudado

No gráfico da Figura 5.8, nota-se que a maior parte do material é composta por concreto e argamassa, uma vez que corresponde a mais de $40 \%$ do total. Já a parcela de telha de amianto (atualmente considerado material indesejado por ser cancerígeno), participa com uma fração muito pequena, ou menos que $0,5 \%$.

Constata-se ainda, em termos de granulometria, que a fração areia está presente de forma significativa, em cerca de um quarto do total. Isto pode facilitar a compactação e ajudar no travamento dos agregados graúdos (diâmetros acima de 4,76mm), por tornar a mistura mais coesa e diminuir o volume de vazios.

É interessante observar a expressiva quantidade de brita existente na massa total (material este tido como nobre em pavimentação), cuja não reciclagem poderia ser considerada desperdício.

Posteriormente, os diferentes grupos foram submetidos a um peneiramento seco para verificar as concentrações granulométricas de cada um. As aberturas de peneiras utilizadas foram $63,5 \mathrm{~mm} ; 25,4 \mathrm{~mm} ; 19,1 \mathrm{~mm} ; 12,5 \mathrm{~mm} ; 9,52 \mathrm{~mm}$; e $4,76 \mathrm{~mm}$.

Da Figura 5.9 à Figura 5.13 são ilustradas as frações graúdas retidas. Já a Figura 5.14 apresenta a porção de material fino (menor que 4,76mm). 


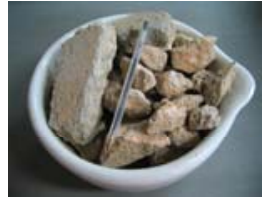

63,5 a $25,0 \mathrm{~mm}$

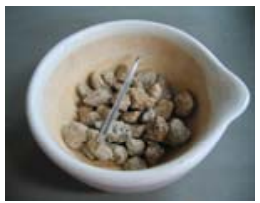

25,0 a $19,1 \mathrm{~mm}$

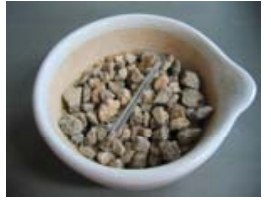

19,1 a $12,5 \mathrm{~mm}$

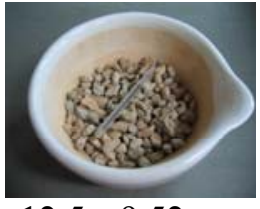

12,5 a $9,52 \mathrm{~mm}$

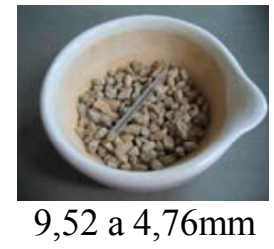

9,52 a $4,76 \mathrm{~mm}$

Figura 5.9: Concreto e argamassa retidos nas peneiras citadas

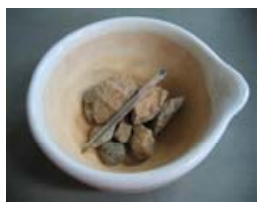

63,5 a $25,0 \mathrm{~mm}$

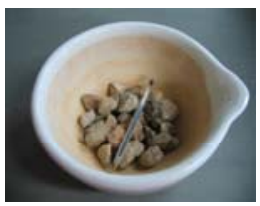

25,0 a $19,1 \mathrm{~mm}$

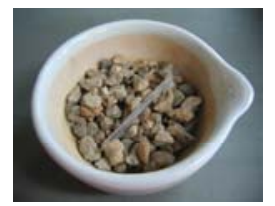

19,1 a $12,5 \mathrm{~mm}$

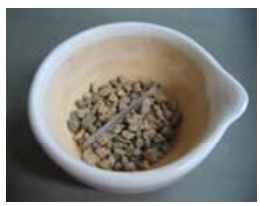

12,5 a $9,52 \mathrm{~mm}$

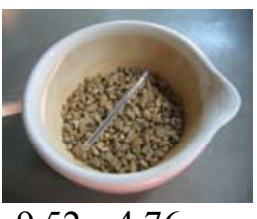

9,52 a $4,76 \mathrm{~mm}$

Figura 5.10: Brita retida nas peneiras citadas

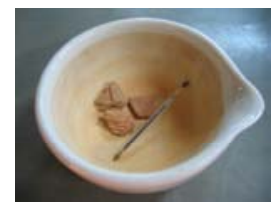

63,5 a $25,0 \mathrm{~mm}$

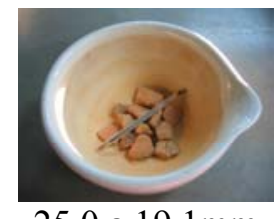

25,0 a $19,1 \mathrm{~mm}$

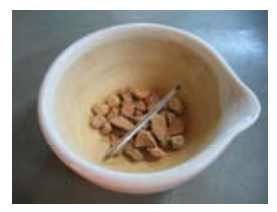

19,1 a $12,5 \mathrm{~mm}$

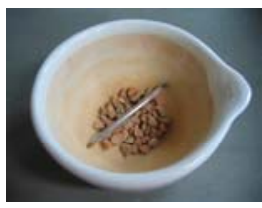

12,5 a $9,52 \mathrm{~mm}$

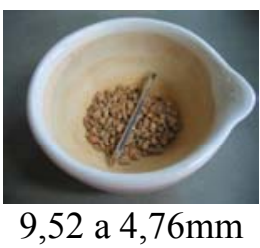

9,52 a $4,76 \mathrm{~mm}$

Figura 5.11: Telha e tijolo retidos nas peneiras citadas

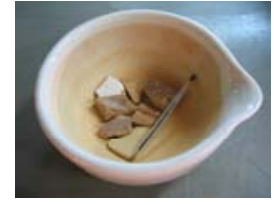

63,5 a $25,0 \mathrm{~mm}$

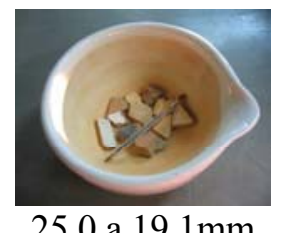

25,0 a $19,1 \mathrm{~mm}$

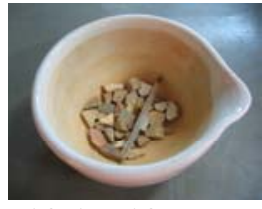

19,1 a $12,5 \mathrm{~mm}$

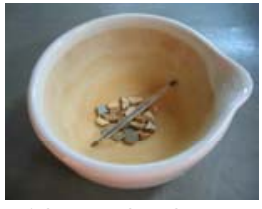

12,5 a $9,52 \mathrm{~mm}$

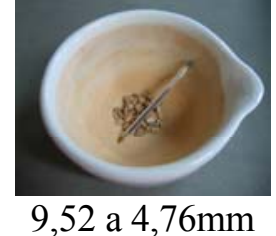

Figura 5.12: Piso e azulejo retidos nas peneiras citadas

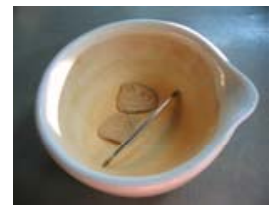

63,5 a $25,0 \mathrm{~mm}$

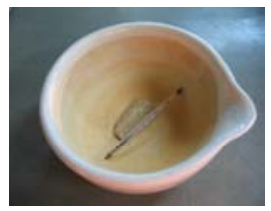

25,0 a $19,1 \mathrm{~mm}$

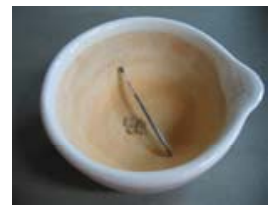

19,1 a $12,5 \mathrm{~mm}$

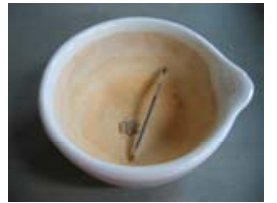

12,5 a $9,52 \mathrm{~mm}$

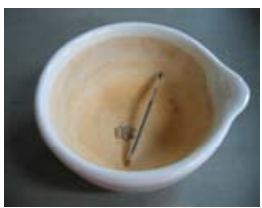

9,52 a $4,76 \mathrm{~mm}$

Figura 5.13: Telha de amianto retida nas peneiras citadas

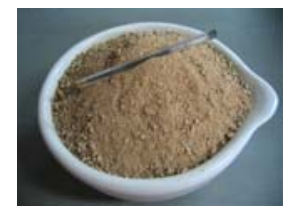

Figura 5.14: Material fino passado na peneira 4,76mm 
Na seqüência, a Figura 5.15 indica as concentrações granulométricas dos materiais analisados, considerando somente a fração graúda.

(5)

(4)

(3)

(2)

(1)
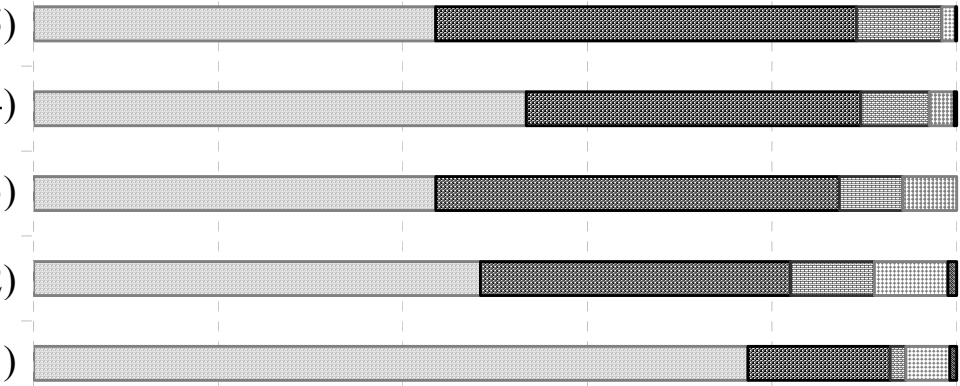

$\begin{array}{llllll}0 \% & 20 \% & 40 \% & 60 \% & 80 \% & 100 \%\end{array}$

Porcentagem retida em massa

$\square$ concreto $\square$ brita $\square$ telha/tijolo $\square$ piso/azulejo $\square$ telha de amianto

(1) entre peneiras 63,5 e 25mm; (2) entre peneiras 25 e 19,1 $1 \mathrm{~mm}$; (3) entre peneiras 19,1 e 12,5mm; (4) entre peneiras 12,5 e 9,52mm; (5) entre peneiras 9,52 e 4,76mm

Figura 5.15: Concentrações granulométricas dos materiais constituintes do agregado reciclado estudado

Por meio da Figura 5.15, é possível observar que do material retido na peneira 4,76mm: o concreto e argamassa compõem a maior parte da fração entre as peneiras $63,5 \mathrm{~mm}$ e $25,4 \mathrm{~mm}$, ou $80 \%$ da massa total; a brita está mais presente na porção entre $9,52 \mathrm{~mm}$ e $4,76 \mathrm{~mm}$; a telha e tijolo se distribuem de forma aproximadamente semelhante em todas as frações, exceto entre $63,5 \mathrm{~mm}$ e $25,4 \mathrm{~mm}$, onde a ocorrência foi menos significativa; o piso e azulejo estão menos presentes entre $12,5 \mathrm{~mm}$ e 4,76mm; e a pequena porção de telha de amianto da amostra só se apresenta de maneira relativamente expressiva entre $19,1 \mathrm{~mm}$ e $63,5 \mathrm{~mm}$.

\subsubsection{Distribuição granulométrica}

Segundo o DNER (1996), a graduação do agregado, representada pela curva de distribuição granulométrica, é uma das características que asseguram estabilidade aos pavimentos em função do maior atrito interno obtido por entrosamento das partículas, da mais graúda à mais fina. 
A análise da granulometria do agregado reciclado foi feita por meio de peneiramento a seco (Figura 5.16) de acordo com a especificação NBR 7181 (1984), e a curva granulométrica obtida está representada na Figura 5.17.

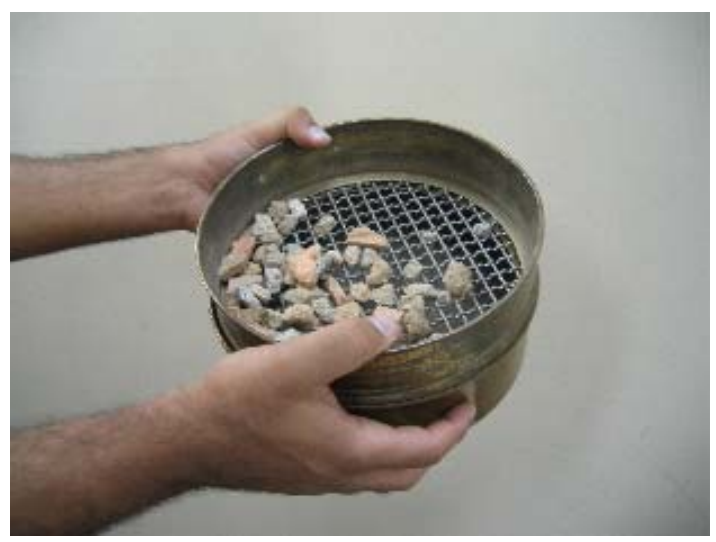

Figura 5.16: Peneiramento a seco do agregado reciclado

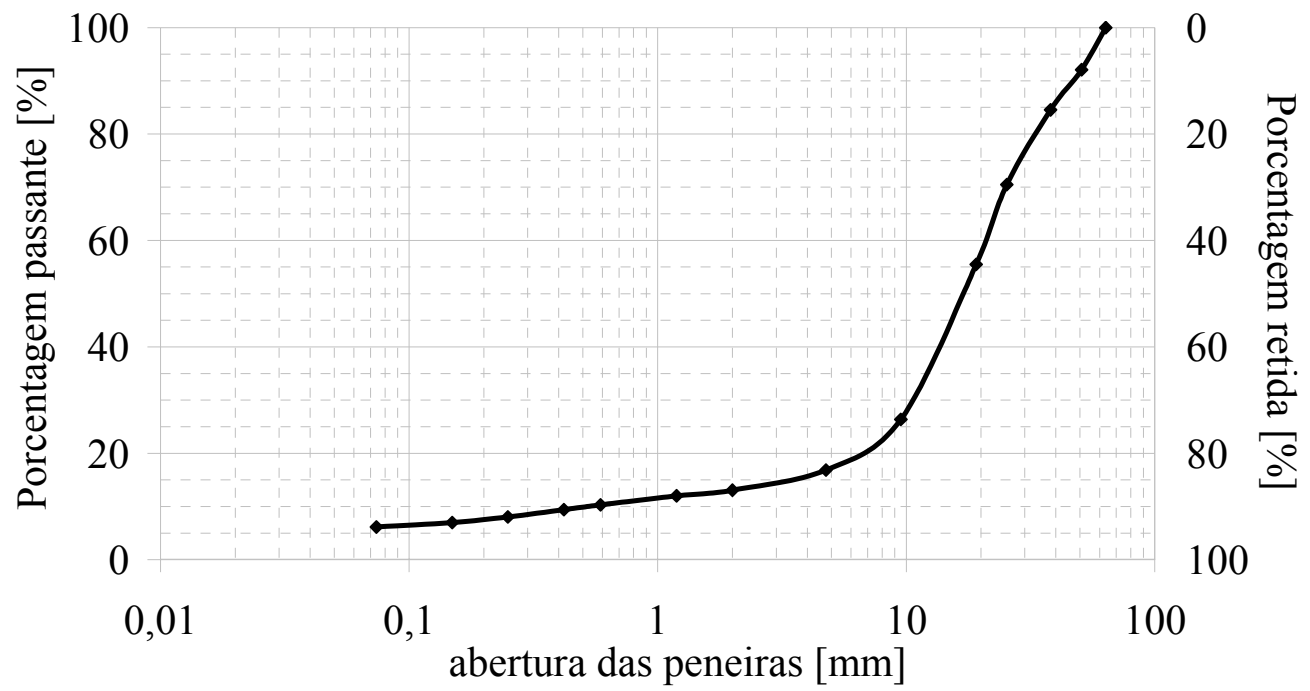

Figura 5.17: Distribuição granulométrica do agregado reciclado estudado

Notou-se nesta experiência que, devido à baixa resistência à abrasão do agregado reciclado (que será examinada no item 5.4.5), a própria operação de agitação das peneiras culminava muitas vezes com o fracionamento de grãos durante a execução do peneiramento. Desta forma, torna-se difícil enquadrar o material em uma faixa granulométrica normalizada, em função da possibilidade de alteração da curva de distribuição dos grãos. 
O que deve-se assegurar, no caso da granulometria, é a distribuição contínua, para que os grãos menores promovam um melhor embricamento com os grãos maiores. A NBR 15115 (2004) especifica que o Coeficiente de Uniformidade $\left(\mathrm{C}_{\mathrm{u}}\right)$, que é a relação entre os diâmetros que correspondem a $60 \%$ e $10 \%$ passantes na curva granulométrica, deve ser maior ou igual a 10. Como nesta pesquisa encontrou-se o valor de 42, o mesmo satisfaz plenamente a especificação brasileira, e este resultado demonstra que o agregado reciclado desta pesquisa é bem graduado e não-uniforme.

Um outro quesito verificado neste ensaio foi a porcentagem de material passante na peneira 0,42mm que, segundo a NBR 15115 (2004), deve ficar entre 10\% e 40\%. Este item da norma visa garantir uma quantidade mínima de material fino no montante de agregado reciclado para promover um maior embricamento de sua fração graúda. Com base na Figura 5.17, é possível observar que o agregado reciclado apresentou valor em torno de $10 \%$, o que significa que o material satisfaz este item da especificação.

\subsubsection{Absorção}

A capacidade de absorção de um material, que está relacionada com a sua porosidade e conseqüentemente com a sua resistência, pode ser determinada após 24 horas de sua imersão em água à temperatura ambiente (Figura 5.18).

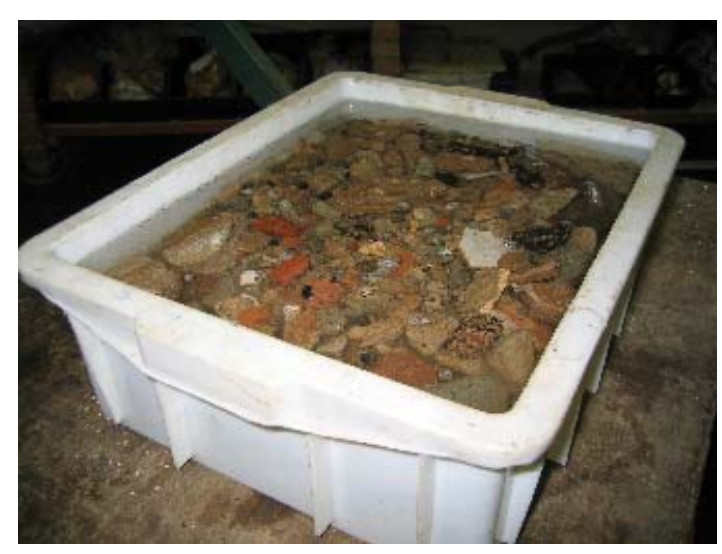

Figura 5.18: Agregado reciclado submetido à absorção de água 
Nesta pesquisa, o experimento foi realizado de acordo com a especificação DNERME 081/98 (1998). O cálculo para determinar o teor de absorção foi realizado de com base na expressão (1):

$a=\frac{M_{h}-M_{S}}{M_{S}} * 100$

onde:

a é o teor de absorção, em [\%];

$M_{h}$ é a massa do material na condição saturada superfície seca, em [g];

$M_{s}$ é a massas do material seco, em [g].

O teor de absorção de água obtido para o agregado reciclado foi de 7,8\%.

Cabe ressaltar que o resultado deste ensaio serviu de parâmetro na escolha dos teores de umidade testados no ensaio de compactação (item 5.6) e na verificação da variação do peso específico aparente seco com a energia de compactação (item 5.7).

Para fins de comparação, a Tabela 5.1 aponta alguns resultados de teor de absorção encontrados em pesquisas com diferentes tipos de agregado reciclado.

Tabela 5.1: Teores de absorção de água encontrados em algumas pesquisas

\begin{tabular}{|c|c|c|c|}
\hline Tipo de agregado reciclado & Procedência & $\begin{array}{c}\text { Teor de } \\
\text { absorção } \\
{[\%]}\end{array}$ & Autor \\
\hline Sem cerâmicos e gesso & $\begin{array}{l}\text { Manaus } \\
(\mathrm{AM})\end{array}$ & 9,0 & $\begin{array}{l}\text { Frota et al. } \\
\quad(2003)\end{array}$ \\
\hline Fração graúda de tipo não especificado & \multirow{2}{*}{$\begin{array}{l}\text { Salvador } \\
\text { (BA) }\end{array}$} & 8,2 & \multirow{2}{*}{$\begin{array}{c}\text { Carneiro et al. } \\
\quad \text { (2001) }\end{array}$} \\
\hline Fração miúda de tipo não especificado & & 10,4 & \\
\hline Fração graúda de tipo não especificado & \multirow{2}{*}{$\begin{array}{l}\text { Hong Kong } \\
\text { China }\end{array}$} & 5,8 & \multirow{2}{*}{$\begin{array}{l}\text { Poon } \\
\text { (1997) }\end{array}$} \\
\hline Fração miúda de tipo não especificado & & 11,4 & \\
\hline Concreto & $\begin{array}{c}\text { Taejon } \\
\text { Coréia do Sul }\end{array}$ & $6,2^{(\mathrm{i})}$ & $\begin{array}{l}\text { Lim et al. } \\
\text { (2001) }\end{array}$ \\
\hline
\end{tabular}

${ }^{(i)}$ Valor médio 
Ao observar os valores apresentados na Tabela 5.1, é possível concluir que há uma significativa variação entre os resultados obtidos nos ensaios de absorção de água, que pode ter ocorrido devido à heterogeneidade dos tipos analisados. De qualquer forma, o teor de absorção do agregado reciclado do presente estudo $(7,8 \%)$ assemelhou-se mais àquele alcançado com o agregado reciclado graúdo de Salvador $(8,2 \%)$.

Como em britas tem-se verificado teores de absorção inferiores a $2 \%$, então verificase que o agregado reciclado é muito mais poroso. Com isto, a quantidade de água que deve ser adicionada ao mesmo por ocasião de sua compactação deve ser maior que a dos materiais pétreos convencionais.

\subsubsection{Determinação da atividade pozolânica}

Segundo Lea (1938) ${ }^{(18)}$ apud Morales (1994), a pozolana é um material silicoso ou sílico-aluminoso que, finamente moído e na presença de água, reage com hidróxido de cálcio e forma compostos com propriedades cimentíceas. A esta reação é dado o nome de reação pozolânica.

O potencial pozolânico de um material pode ser avaliado pelo Método de Chapelle Modificado apresentado por Raverdy et al. (1980) ${ }^{(19)}$ apud Morales (1994), ou por Raverdy et al. (1980) ${ }^{(19)}$ apud Hamassaki et al. (1996).

Este ensaio consiste em colocar $1 \mathrm{~g}$ da parte fina da amostra a ser analisada juntamente com $1 \mathrm{~g}$ de óxido de cálcio $(\mathrm{CaO})$ em uma solução aquosa, que permanece em banho-maria a $97^{\circ} \mathrm{C}$ e sob agitação por um período de 16 horas. A Figura 5.19 apresenta um esboço do equipamento utilizado no ensaio de Chapelle Modificado, segundo Raverdy et al. (1980) ${ }^{(19)}$ apud Morales (1994).

(18) LEA, F. M. The chemistry of pozzolans. In: SYMPOSIUM ON THE CHEMISTRY OF CEMENT. Stockholm, 1938. Proceedings.

(19) RAVERDY, M.; BRIVOT, F; PAILlERE, A. M.; DRON, R. Appréciation de I'activité pouzzolanique des constituants secondaires. In: CONGRĖS INTERNATIONAL DE LA CHIMIE DES CIMENTS, 7., Paris, 1980. Proceedings. v.3, IV-36/41. 


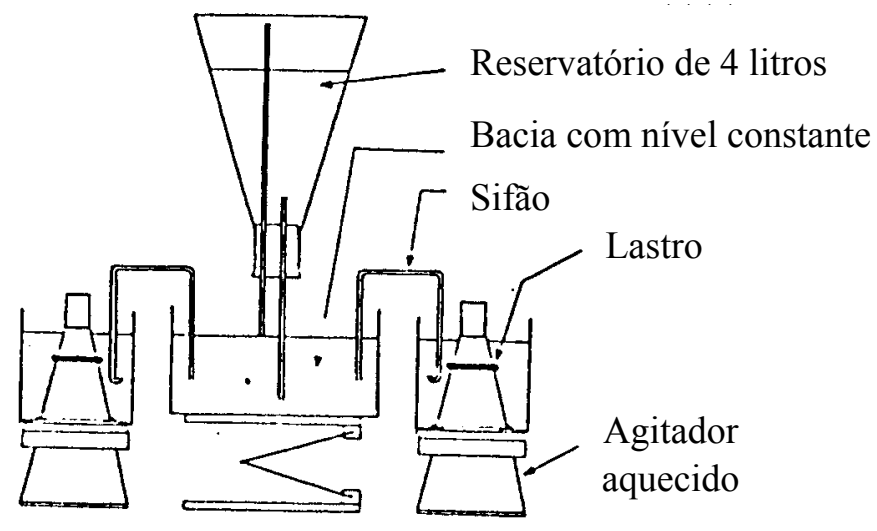

Figura 5.19: Equipamento para o ensaio de Chapelle Modificado, segundo figura retirada de Morales (1994) apud Raverdy et al. (1980), com modificações

O resultado desta experiência é expresso em $\mathrm{mg}$ de $\mathrm{CaO} / \mathrm{g}$ consumido, sendo que para ser considerado uma pozolana o material deve apresentar um índice de consumo de óxido de cálcio de pelo menos 330mg (RAVERDY et al., 1980 ${ }^{(20)}$ apud HAMASSAKI et al., 1996).

Nesta pesquisa, este ensaio foi realizado a fim de verificar se o agregado reciclado estudado poderia sofrer reações pozolânicas que implicariam em possíveis ganhos de resistência nos ensaios mecânicos a serem descritos no item 5.8.

O experimento pelo Método de Chapelle Modificado foi realizado no Laboratório de Química de Materiais de Construção do IPT, e contou com o apoio do aluno de doutorado Sérgio Ângulo e do Prof. Dr. Vanderley John, ambos do Departamento de Construção Civil da EPUSP.

Foram analisadas cinco amostras de finos provenientes de agregados reciclados, sendo duas delas do material coletado para esta pesquisa. As outras três amostras foram fornecidas pelo aluno Sérgio Ângulo, que está estudando em sua tese de doutorado os agregados reciclados também oriundos da usina de reciclagem da PMSP - tipos cinza e vermelho - além de material oriundo da cidade de Vinhedo (no interior do estado de São Paulo).

(20) RAVERDY, M.; BRIVOT, F; PAILlERE, A. M.; DRON, R. Appréciation de I'activité pouzzolanique des constituants secondaires. In: CONGRÈS INTERNATIONAL DE LA CHIMIE DES CIMENTS, 7., Paris, 1980. Proceedings. v.3, IV-36/41. 
A Tabela 5.2 apresenta os resultados referentes à atividade pozolânica dos finos dos agregados reciclados, obtidos pelo Método de Chapelle Modificado.

Tabela 5.2: Resultados de atividade pozolânica do agregado reciclado obtidos pelo Método de Chapelle Modificado

\begin{tabular}{|c|c|c||}
\hline $\begin{array}{c}\text { Recicladora e tipo } \\
\text { de agregado reciclado }\end{array}$ & $\begin{array}{c}\text { Dimensão característica } \\
\text { máxima das partículas } \\
{[\mathbf{m m}]}\end{array}$ & $\begin{array}{c}\text { Atividade pozolânica } \\
\text { Consumo de CaO/g de amostra } \\
\text { [mg] }\end{array}$ \\
\hline \hline PMSP cinza & 0,15 & 72 \\
\hline PMSP vermelho & 0,15 & 108 \\
\hline \hline Vinhedo vermelho & 0,15 & 139 \\
\hline \hline PMSP misto & 0,15 & 134 \\
\hline PMSP misto $^{(j)}$ & 0,074 & 130 \\
\hline
\end{tabular}

${ }^{(j)}$ Material desta pesquisa

Como é possível observar na Tabela 5.2, o ensaio foi realizado com duas frações diferentes do material desta pesquisa, denominadas de "PMSP misto", sendo uma passante na peneira $0,15 \mathrm{~mm}$ e outra na $0,074 \mathrm{~mm}$. Mas embora a graduação não seja a mesma, os resultados apontaram valores semelhantes, ou 134mg e 130mg, respectivamente.

As amostras "PMSP vermelho" e "PMSP misto" passantes na peneira $0,15 \mathrm{~mm}$, ainda que teoricamente similares devido à granulometria e à procedência (pois foram coletadas no mesmo local), resultaram em valores relativamente distintos, ou $108 \mathrm{mg}$ e $134 \mathrm{mg}$, respectivamente. Esta diferença talvez possa ter ocorrido devido a fatores como forma de amostragem e heterogeneidade natural característica do material.

Levando-se em conta o aspecto granulométrico, dentre as amostras passantes na peneira $0,15 \mathrm{~mm}$, nota-se que o "Vinhedo vermelho" é o que apresentou valor de atividade pozolânica mais próximo do desta pesquisa, ou 139mg e 134mg, respectivamente. 
Comparando-se as amostras vermelhas e mistas com a cinza, tem-se que esta última apresentou valor bem abaixo das demais $(72 \mathrm{mg}$ contra $108 \mathrm{mg}, 139 \mathrm{mg}, 134 \mathrm{mg}$ e 130mg de $\mathrm{CaO} / \mathrm{g}$ de amostra). Da mesma forma, Hamassaki et al. (1996) realizaram o ensaio pelo Método de Chapelle Modificado com diferentes frações de resíduos de construção e encontraram valores díspares entre o concreto e a parte cerâmica. A análise foi feita com bloco de concreto, bloco cerâmico e tijolo, sendo encontrados consumos de 53,6mg, 137,1 mg e 255,8mg de $\mathrm{CaO} / \mathrm{g}$ de amostra, respectivamente.

Uma possível explicação para as diferenças apresentadas entre os materiais cinza e vermelho ou cinza e misto, pode residir no fato de como são produzidas as cerâmicas contidas nas amostras vermelhas e mistas. A calcinação das matérias-primas utilizadas na fabricação de cerâmicas visa desenvolver as propriedades pozolânicas do material, devendo ser realizada em determinadas temperaturas para atingir tal objetivo. As temperaturas ótimas de queima estão entre $700^{\circ} \mathrm{C}$ e $900^{\circ} \mathrm{C}$; temperaturas abaixo produzem pozolanas pouco eficientes, e acima geram um material praticamente inativo (SANTOS, 1975). Assim, é possível que o agregado reciclado estudado contivesse material cerâmico com potencial para desenvolver reações pozolânicas em decorrência de calcinação inadequada durante seu processo de produção.

Apesar de todos os valores encontrados nesta pesquisa serem inferiores aos 330mg especificados, não se pode descartar que a reatividade pozolânica do agregado reciclado não possa influenciar positivamente na resistência mecânica do pavimento. Isto porque os $330 \mathrm{mg}$ de consumo de $\mathrm{CaO}$ foram especificados para o concreto, cujos valores de resistência são extremamente elevados. Desta forma, um ganho de resistência que pode ser considerado baixo para o concreto pode não o ser para um pavimento.

Hamassaki et al. (1996), que também obtiveram valores de atividade pozolânica abaixo dos 330mg especificados, mencionam que isto "não anula a possibilidade de se contar com esse efeito, principalmente com relação aos materiais de origem cerâmica, mas sugere que se busquem meios de adequar estes materiais e avaliar até 
quanto, a pozolanicidade, ainda que pequena, pode contribuir no desempenho" (p.115).

\subsubsection{Resistência ao desgaste}

A ação dos equipamentos de compactação, o tráfego ou ainda os movimentos recíprocos das diversas partículas em uma estrutura de pavimento podem influenciar na resistência ao desgaste dos agregados (DIAS, 2004; DNER, 1996). Este desgaste ou abrasão de um dado material pode ser avaliado por meio do ensaio de abrasão "Los Angeles".

Segundo o DNER (1996), a perda à abrasão "Los Angeles" consiste em submeter ao cilindro de uma máquina de mesmo nome (Figura 5.20) uma determinada quantidade de agregado a uma certa seqüência de revoluções. Um grupo de esferas de aço padronizadas é misturado ao material e induz impactos violentos nos grãos por ocasião do movimento de rotação do cilindro.

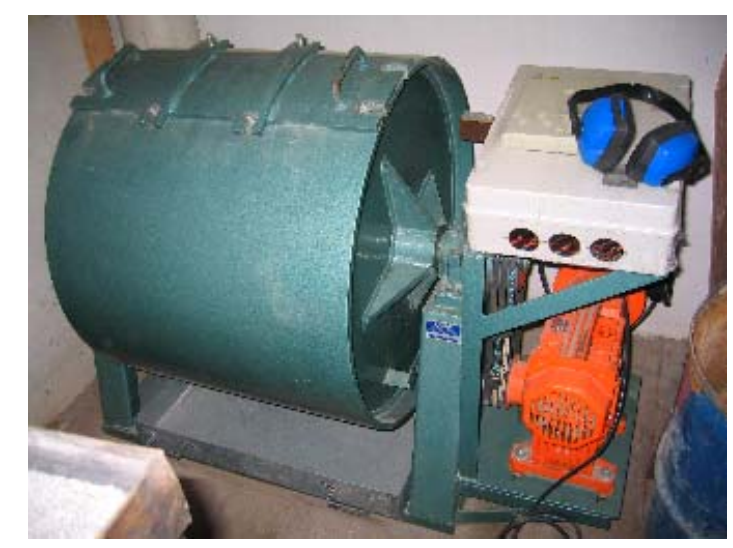

Figura 5.20: Equipamento "Los Angeles" do LTP-EPUSP

Nesta pesquisa, este experimento foi realizado de acordo com a norma DNER-ME 035/98 (1998), utilizando a graduação B da especificação (onde uma parte dos grãos deve ser passante na peneira $19,1 \mathrm{~mm}$ e retida na $12,5 \mathrm{~mm}$, e outra passante na $12,5 \mathrm{~mm}$ e retida na $9,52 \mathrm{~mm})$. 
O tambor, em que foram introduzidos o material e as 11 esferas, foi submetido a 500 rotações, à uma velocidade de 31 rotações por minuto, conforme especificado para graduação B.

A abrasão "Los Angeles" do agregado reciclado foi calculada segundo a expressão (2).

$A_{B}=\frac{m_{B}-m_{B}^{\prime}}{m_{B}} * 100$

onde:

$A_{B}$ é o valor da abrasão "Los Angeles", em [\%];

$m_{B}$ é a massa total do material ensaiado, em [g];

$m_{B}{ }_{B}$ é a massa do material retido na peneira de abertura igual a $1,7 \mathrm{~mm}$, em [g].

A Figura 5.21 ilustra as duas frações do agregado reciclado estudado que foram sujeitas à abrasão "Los Angeles", e a Figura 5.22 mostra a aparência do material retido e passado pela peneira de $1,7 \mathrm{~mm}$ após o desgaste.

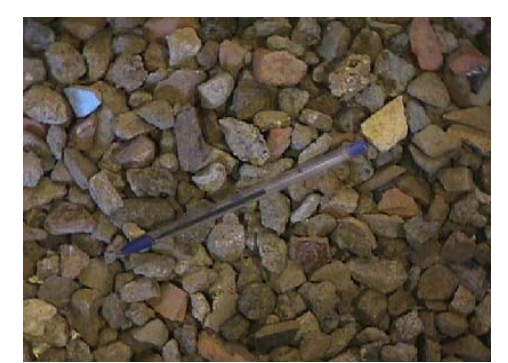

entre peneiras 19,1 e $12,5 \mathrm{~mm}$

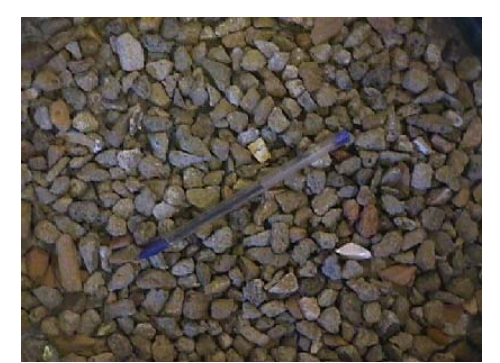

entre peneiras 12,5 e $9,52 \mathrm{~mm}$

Figura 5.21: Frações granulométricas submetidas à abrasão "Los Angeles" 


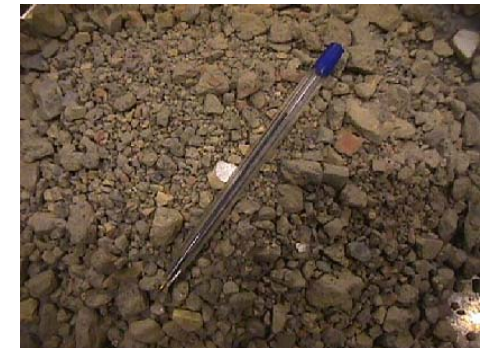

retido na peneira $1,7 \mathrm{~mm}$

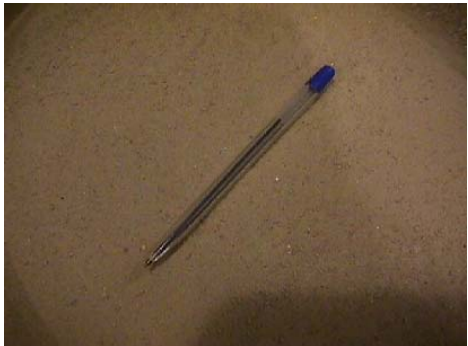

passado na peneira $1,7 \mathrm{~mm}$

Figura 5.22: Aparência do agregado reciclado retido e passado na peneira $1,7 \mathrm{~mm}$ após o desgaste

A abrasão "Los Angeles" do agregado reciclado resultou em 49,79\% que, segundo a norma, deve ser expressa com aproximação de 1\%, ou seja, o valor final é 50\%.

A NBR 15115 (2004) não faz alusão a valor ou faixa de valores limites para a abrasão "Los Angeles". Porém, a título de comparação, sub-bases e bases estabilizadas granulometricamente devem apresentar abrasão "Los Angeles" de até 55\%, segundo a NBR 11804 (1991); já a brita graduada deve ter abrasão menor que 40\%, de acordo com a NBR 11806 (1991).

Entretanto, a porcentagem relativamente elevada face as normas apresentadas para outros tipos de agregados não deve significar que o reciclado não possa ser considerado para o uso em pavimentação; os experimentos mecânicos são melhores indicadores para a análise de aplicabilidade destes materiais.

Dias (2004) menciona que "nem sempre se pode garantir que um agregado, que atenda à especificação do limite Los Angeles, não estará sujeito à alteração granulométrica, porquanto as condições do arranjo, a porosidade, e a forma dos grãos vão interferir no seu desempenho frente à ação das cargas” (p.77).

Fernandes (2004) realizou ensaio de abrasão "Los Angeles" com agregados reciclados de alguns locais brasileiros, cujos resultados estão na Tabela 5.3. 
Tabela 5.3: Abrasão "Los Angeles" obtida com alguns agregados reciclados brasileiros

\begin{tabular}{|c||c||c||c|}
\hline $\begin{array}{c}\text { Tipo de } \\
\text { agregado reciclado }\end{array}$ & Procedência & Graduação & $\begin{array}{c}\text { Abrasão } \\
\text { [os Angeles" } \\
{[\%]}\end{array}$ \\
\hline brita corrida mista & Belo Horizonte & A & 55 \\
\hline brita corrida de concreto & $(\mathrm{MG})$ & $\mathrm{A}$ & 52 \\
\hline brita 0 mista & Rio de Janeiro & $\mathrm{C}$ & 59 \\
\hline brita 1 mista & (RJ) & B & 66 \\
\hline
\end{tabular}

Perante os valores apresentados na Tabela 5.3, nota-se que a abrasão "Los Angeles" que mais se aproxima da encontrada nesta pesquisa (equivalente a 50\%) é a da brita corrida de concreto (igual a 52\%), embora as graduações do ensaio sejam diferentes.

Em dois estudos realizados especificamente com agregados reciclados de concreto, sendo um da Dinamarca (REID, 2000) e outro da Coréia do Sul (LIM et al., 2001), encontrou-se abrasão "Los Angeles" de 32\% e 40,8\% ${ }^{(21)}$, respectivamente, diferindo significativamente do valor apontado na Tabela 5.3 para agregados reciclados de concreto do Brasil, cujo desgaste alcançou $52 \%$.

Percebe-se que há variação significativa do resultado de ensaio de abrasão "Los Angeles" entre os agregados reciclados analisados, possivelmente devido à sua composição e origem, o que mostra que estipular um valor limite de desgaste para este tipo de material seria tarefa difícil.

Dias (2004) cita que, "embora a abrasão Los Angeles seja um ensaio clássico para a escolha e seleção de agregados destinados à pavimentação" (p.76), o DNER entendeu que no Brasil "devem ser desenvolvidos ensaios tecnológicos novos e/ou adaptados" (p.77) às condições ambientais do país. Isto porque a experiência com rochas gnáissicas de origem metamórfica na região sudeste brasileira demonstra que, apesar dos valores de desgaste serem maiores que os recomendados nas especificações, as mesmas, ainda assim, são usadas em pavimentação (BRASIL -

${ }^{(21)}$ Valor médio 
MINISTÉRIO DOS TRANSPORTES, $1998^{(22)}$ apud DIAS, 2004). Porém, o autor não especifica se nestes casos tem-se obtido sucesso.

Vale ressaltar que a especificação DNER-ME 035/98 (que foi desenvolvida com base em agregados naturais) também caberia aos agregados reciclados, pois cita que a interpretação do resultado obtido no ensaio de abrasão "Los Angeles" deverá levar em conta composição mineralógica, estrutura e aplicação do material.

\subsubsection{Forma do agregado}

De acordo com o DNER (1996), a forma de um agregado se caracteriza por sua feição exterior relacionada às suas dimensões (podendo ser alongada, esférica, cúbica ou lamelar), e também a seus tipos de arestas e cantos (anguloso ou arredondado).

Em pavimentação, procura-se não utilizar agregados de formas lamelares, pois estes tendem a se fracionar facilmente quando sofrem a aplicação de uma carga, e isto pode interferir no arranjo da estrutura de uma camada, vindo a ocasionar alguma patologia como, por exemplo, afundamentos por consolidação.

A determinação da forma da fração graúda do agregado reciclado estudado foi feita de maneira análoga ao especificado na NBR 6954 (1989). Segundo esta norma, devem ser medidos altura, largura e comprimento dos grãos (Figura 5.23) para classificar o material como sendo cúbico, alongado, lamelar ou alongado-lamelar.

Para este ensaio foram empregados agregados reciclados retidos nas peneiras $38,1 \mathrm{~mm}^{(23)}, 25,4 \mathrm{~mm}, 19,1 \mathrm{~mm}$ e $9,52 \mathrm{~mm}$ (Figura 5.24) de uma das amostras representativas obtidas no item 5.3. No caso das três primeiras peneiras, fez-se uso de todos os grãos retidos em cada uma delas e, no caso da 9,52mm, optou-se por analisar um grupo de 200 grãos, ou o equivalente a $25 \%$ do total desta fração.

\footnotetext{
${ }^{(22)}$ BRASIL - Ministério dos Transportes - DNER. Estudos e pesquisas de rochas de pedreiras para estabelecimento de critérios de qualidade frente às normas e procedimentos existentes e sua aceitação. Rio de Janeiro: IPR, 1998. 153p. Relatório Final.

${ }^{(23)}$ Este caso se refere aos grãos retidos entre as peneiras $50,8 \mathrm{~mm}$ e $38,1 \mathrm{~mm}$.
} 


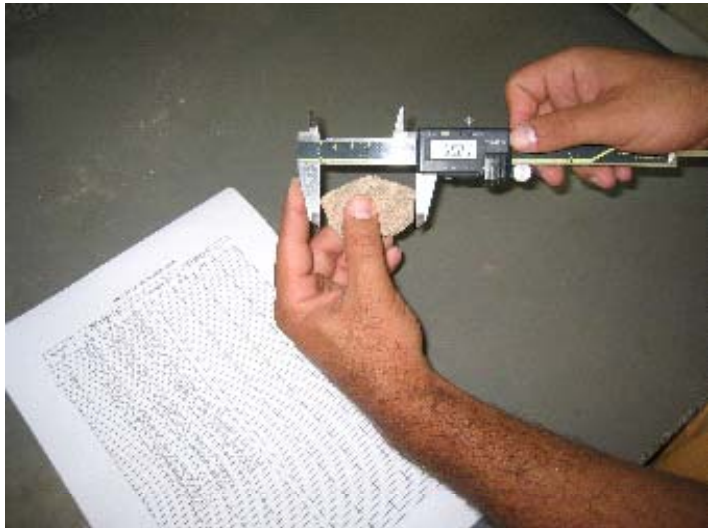

Figura 5.23: Leitura para determinação da forma do agregado reciclado estudado

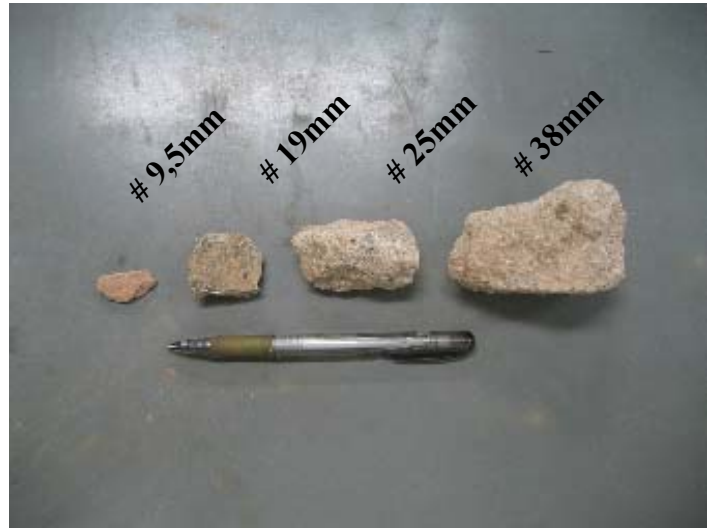

Figura 5.24: Frações granulométricas para determinação da forma do agregado reciclado estudado

Os dados obtidos apontaram que as quatro frações granulométricas analisadas indicaram forma cúbica, o que em termos de pavimentação significa um bom resultado.

De acordo com Fernandes (2004), "a cubicidade dos agregados reciclados, principalmente aqueles de tipo misto, decorre em parte da sua suscetibilidade ao desgaste superficial das partículas" (p.88).

\subsubsection{Teor de materiais indesejáveis}

Embora seja feita a separação prévia das diferentes classes de resíduos no processo de reciclagem, ainda é possível encontrar componentes ditos "indesejáveis" ou “contaminantes" (pertencentes às Classes B, C e D, segundo a Resolução CONAMA de 2002) no produto final.

A retirada completa de materiais indesejáveis de um grupo de resíduos de construção ou de agregados reciclados pode ser uma tarefa difícil. Isto porque, no caso da ocorrência de componentes de pequenas dimensões, os mesmos podem não ser facilmente visíveis, dificultando sua separação.

$\mathrm{Na}$ Austrália, os limites de materiais indesejáveis estão condicionados ao próprio tipo de contaminante, à categoria de tráfego a que o pavimento vai ser submetido (onde o 
número $\mathrm{N}$ de veículos pode variar até $10^{7}$ ) e ao tipo de aplicação (base ou sub-base). A partir daí, os teores máximos permitidos, em massa, podem variar de $0,1 \%$ a $5 \%$ para bases, e de 0,2\% a 5\% para sub-bases, segundo a norma RTA Q3051 - Unbound and Modified Base and Subbase Materials for Surfaced Road Pavements ${ }^{(24)}$, já citada anteriormente no Capítulo 4 (UTS, 1999).

A NBR 15115 (2004) determina que a quantidade de materiais indesejáveis de grupos distintos e de mesmo grupo deve ser de até $3 \%$ e $2 \%$, em massa, respectivamente.

No montante de agregado reciclado coletado para esta pesquisa notou-se a presença de vários tipos de materiais contaminantes (Figura 5.25), mas os principais foram, em ordem quantitativa decrescente: gesso (Figura 5.26), madeira (Figura 5.27) e plástico (Figura 5.28); em quantidades menores, verificou-se também a ocorrência de ferro, isopor, vidro, tecido e papel.

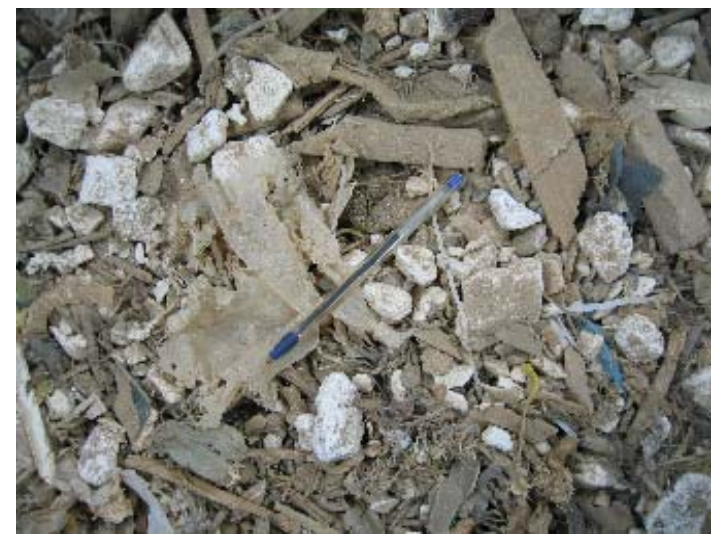

Figura 5.25: Fração de materiais indesejáveis encontrada no agregado reciclado estudado

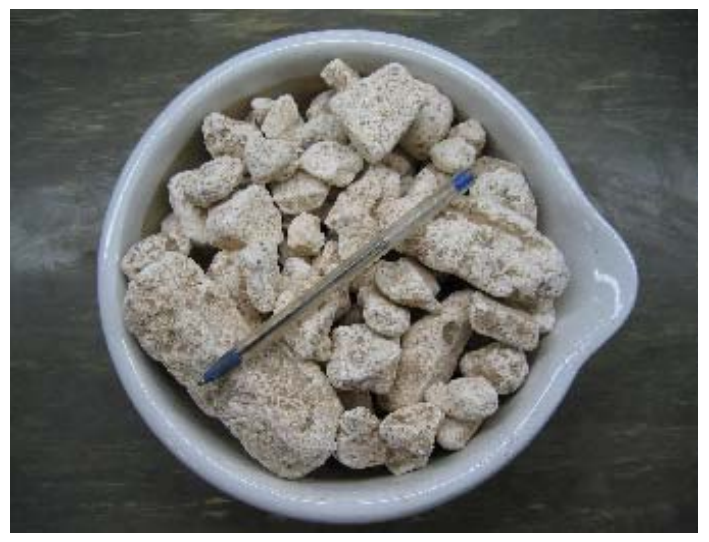

Figura 5.26: Fração de gesso encontrada no agregado reciclado estudado

(24) RTA QA Specification 3051, Unbound and Modified Base and Subbase Materials for Surface Road Pavements. 


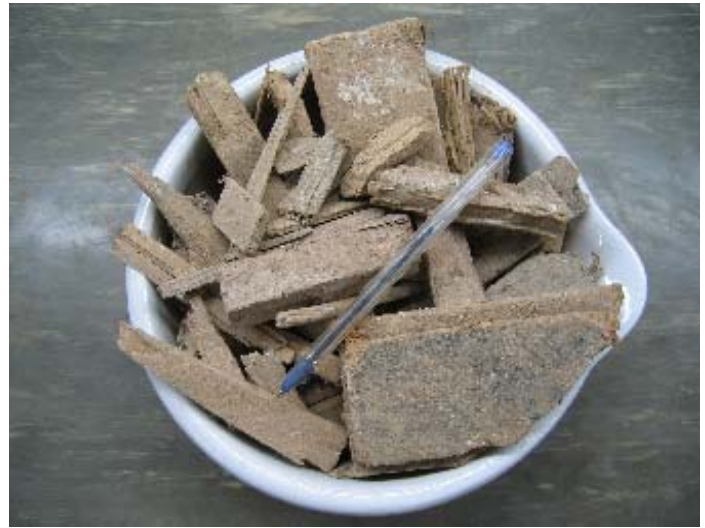

Figura 5.27: Fração de madeira encontrada no agregado reciclado estudado

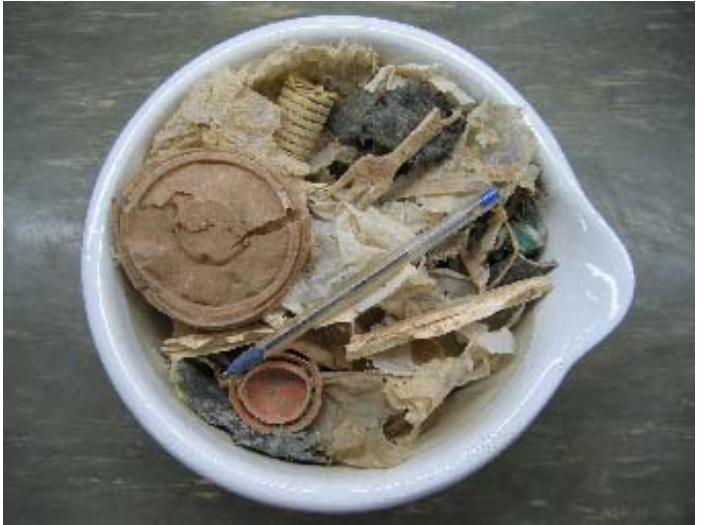

Figura 5.28: Fração de plástico encontrada no agregado reciclado estudado

Fez-se o cálculo da quantidade aproximada de materiais indesejáveis contidos na amostra de agregado reciclado coletada para esta pesquisa e os resultados são apresentados na Tabela 5.4.

Tabela 5.4: Porcentagem estimada de materiais contaminantes contidos no agregado reciclado coletado

\begin{tabular}{|c||c||c|}
\hline $\begin{array}{c}\text { Material } \\
\text { indesejado }\end{array}$ & $\begin{array}{c}\text { Classe na } \\
\text { Resolução CONAMA } \\
\text { de 2002 }\end{array}$ & $\begin{array}{c}\text { Porcentagem encontrada } \\
\text { em relação ao montante coletado } \\
\text { [\% aproximada, em massa] }\end{array}$ \\
\hline Gesso & $\mathrm{C}$ & 0,2 \\
\hline Madeira & $\mathrm{B}$ & 0,1 \\
\hline Plástico & $\mathrm{B}$ & $<0,1$ \\
\hline Outros & B e C & $<0,1$ \\
\hline TOTAL & B e C & $\mathbf{0 , 4}$ \\
\hline
\end{tabular}

Se os números da Tabela 5.4 forem comparados aos limites especificados pela NBR 15115 (2004), verifica-se que os valores encontrados satisfazem plenamente a norma.

No entanto, deve-se atentar para a presença de contaminantes na massa de agregado reciclado, já que, ainda que em pequena quantidade, foram encontrados componentes de grandes dimensões no material estudado (como é possível notar na Figura 5.26 e na Figura 5.27). De acordo com a UTS (1999), a qualidade do material reciclado está 
diretamente relacionada ao nível de contaminação do resíduo de construção e demolição.

O gesso, por exemplo, que foi o tipo de material indesejável mais presente na amostra coletada, quando concentrado em grande quantidade em um determinado ponto da estrutura de um pavimento, pode trazer problemas a longo prazo devido à formação de vazios por sua lixiviação, já que este material é solúvel em água (JOHN e CINCOTTO, 2003).

No caso da madeira, a mesma, além de compressível com o tempo, pode deteriorarse e formar vazios indesejáveis que provoquem recalques diferenciais.

Já vidros, plásticos e metais não se deterioram e não trazem danos ambientais, mas caso estejam presentes em grande quantidade no agregado reciclado, podem trazer problemas na compactação, em função da diminuição do embricamento dos grãos (COSTA e URSELLA, 2003), além de formar volumes de vazios que, assim como no caso da madeira, venham provocar recalques diferenciais.

\subsection{Determinação da energia de compactação}

$\mathrm{Na}$ escolha da energia de compactação que viria a ser utilizada na moldagem dos corpos-de-prova dos ensaios mecânicos, preferiu-se não se utilizar energia Proctor Modificada. Julgou-se que o emprego desta poderia impor uma quebra de grãos muito significativa ao agregado reciclado por este ser um material relativamente abrasivo (como apontado no item 5.4.5), embora acredita-se que o uso de alta energia de compactação seja sempre recomendável.

A opção por energia Proctor Normal ou Intermediária foi feita com base na variação granulométrica sofrida pelo material após ensaio de Índice de Suporte Califórnia (ISC) e no valor da capacidade de suporte obtido neste último experimento. A alteração de granulometria foi verificada, por meio de peneiramento seco, de acordo com a NBR 7181 (1984), e o ISC foi determinado conforme a DNER-ME 049/94 (1994) a partir da compactação de um corpo-de-prova nas duas energias 
supracitadas. A energia Proctor Normal corresponde à compactação em 5 camadas com 12 golpes por camada e a energia Proctor Intermediária equivale à compactação também em 5 camadas, porém com 26 golpes por camada, utilizando soquete padronizado de $4.536 \mathrm{~g}$ e altura de queda de $457 \mathrm{~mm}$.

Como ainda não havia sido realizado o ensaio de compactação para determinação do teor de umidade ótimo, optou-se pelo uso de $12 \%$ de umidade, levando-se em consideração o valor obtido no ensaio de absorção (relacionado no item 5.4.3). No decorrer da pesquisa, com a realização do ensaio de compactação (apresentado no item 5.6), determinou-se que o teor de umidade a ser adotado deveria ser de $11 \%$, demonstrando que o valor de $12 \%$ escolhido nesta etapa ficou próximo da umidade empregada neste item.

Cabe ressaltar que foi necessário fazer a substituição da parte graúda do material, como prescreve a norma DNER-ME 049/94 (1994). Neste processo, a massa de material retida na peneira $19,1 \mathrm{~mm}$ é substituída por outra de grãos retidos entre a $19,1 \mathrm{~mm}$ e a $4,76 \mathrm{~mm}$.

Em termos de ISC, verificou-se que o corpo-de-prova moldado na energia Proctor Normal apresentou valor de $36 \%$ e o que foi compactado na energia Proctor Intermediária resultou em ISC de $84 \%$. Embora seja difícil obter alta repetição no ensaio ISC, a diferença entre os valores obtidos é muito significativa, denotando a expressiva importância da energia de compactação para estes materiais.

A Figura 5.29 e a Figura 5.30 ilustram as curvas que indicam a variação granulométrica apresentada pelos corpos-de-prova após a realização do ensaio de ISC, com base nas porcentagens passantes (ou retidas) e nas porcentagens retidas não acumuladas, respectivamente. 


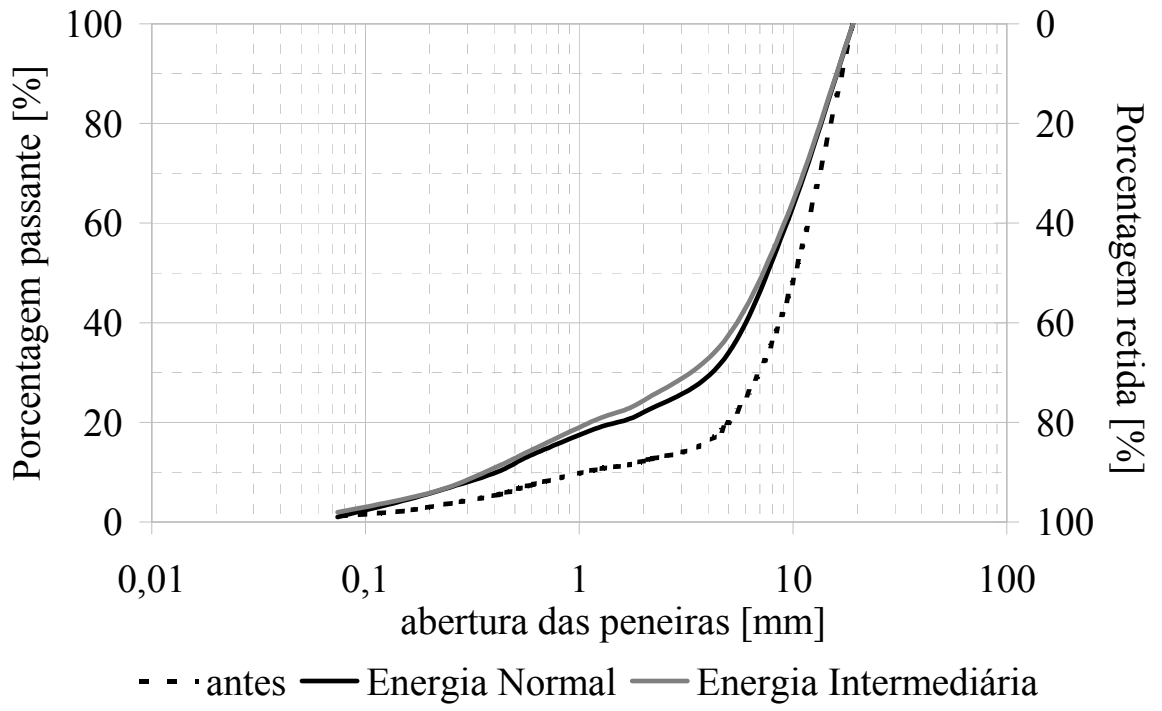

Figura 5.29: Variação granulométrica após ensaio de ISC com corpos-de-prova compactados em energias Proctor Normal e Intermediária, em função de porcentagens passantes (ou retidas)

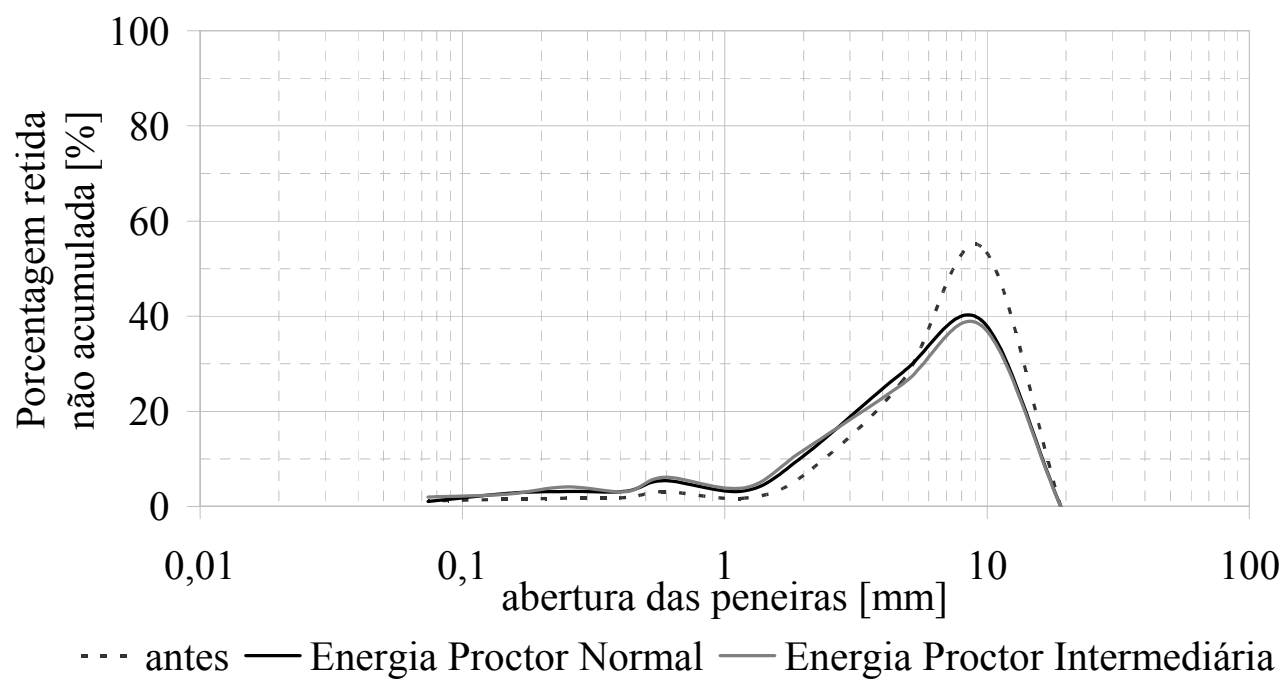

Figura 5.30: Variação granulométrica após ensaio de ISC com corpos-de-prova compactados em energias Proctor Normal e Intermediária, em função de porcentagens retidas não acumuladas

Observa-se que houve significativa mudança no diâmetro nominal dos grãos em relação à curva inicial em ambas energias. Mas embora a Proctor Intermediária seja mais de duas vezes a Proctor Normal, as curvas granulométricas de ambas energias apresentaram uma configuração semelhante. As quebras mais importantes se deram logo nos primeiros estágios de compactação, ou seja, a partir da energia Proctor 
Normal, a aplicação de um maior número de golpes para se atingir a energia Proctor Intermediária implicou em uma quebra de grãos muito menos intensa e isto alterou pouco a distribuição granulométrica.

Por fim, optou-se por trabalhar com a energia Proctor Intermediária, pois esta impôs variação de granulometria praticamente igual ao do material moldado na energia Proctor Normal, e ainda ofereceu valor de suporte expressivamente mais elevado.

\subsection{Ensaio de compactação}

Preliminarmente à fase de caracterização do comportamento mecânico, procedeu-se à determinação do teor ótimo de umidade e do peso específico aparente seco por meio do ensaio de compactação descrito na especificação NBR 7182 (1984).

Segundo o DNER (1996), a compactação é uma operação destinada a reduzir o volume de vazios de um material, com a finalidade de aumentar sua massa específica, resistência e estabilidade.

Nesta pesquisa, em virtude da grande dimensão característica máxima do agregado reciclado $(63,5 \mathrm{~mm})$, optou-se pela compactação em cilindro do tipo tripartido, de $150 \mathrm{~mm}$ de diâmetro por $300 \mathrm{~mm}$ de altura (Figura 5.31 à Figura 5.34), que foi

concebido especialmente para este estudo de mestrado, de modo a evitar a substituição de material exigida na norma.

Medina (1997) cita que a "preparação de corpos-de-prova de materiais granulares, tendo certo grau de coesão, pode ser feita compactando-se por impacto em moldes tripartidos verticalmente" (p.163). 


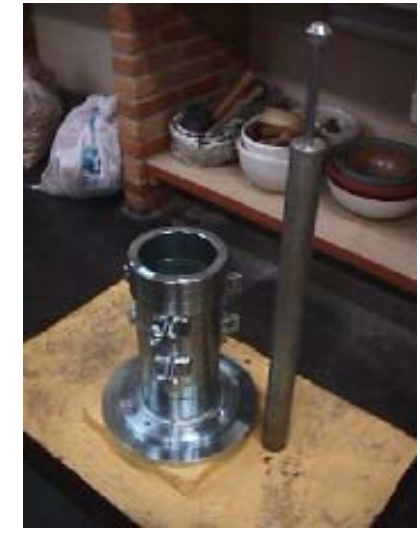

Figura 5.31: Cilindro tripartido e soquete Proctor utilizados

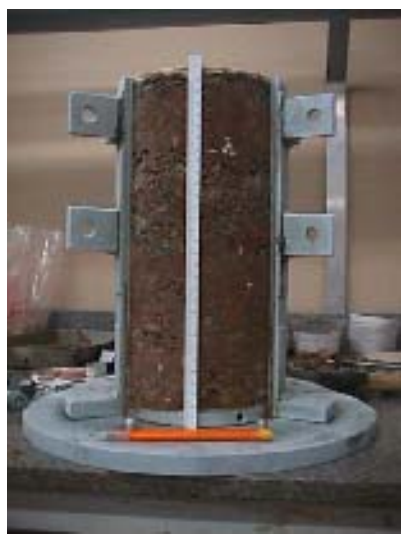

Figura 5.33: Desmoldagem do corpo-deprova

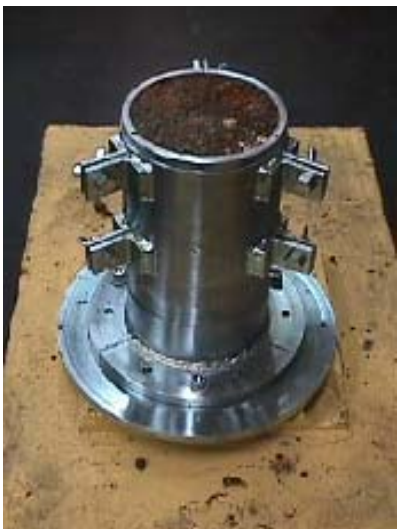

Figura 5.32: Cilindro com o agregado reciclado compactado em seu interior

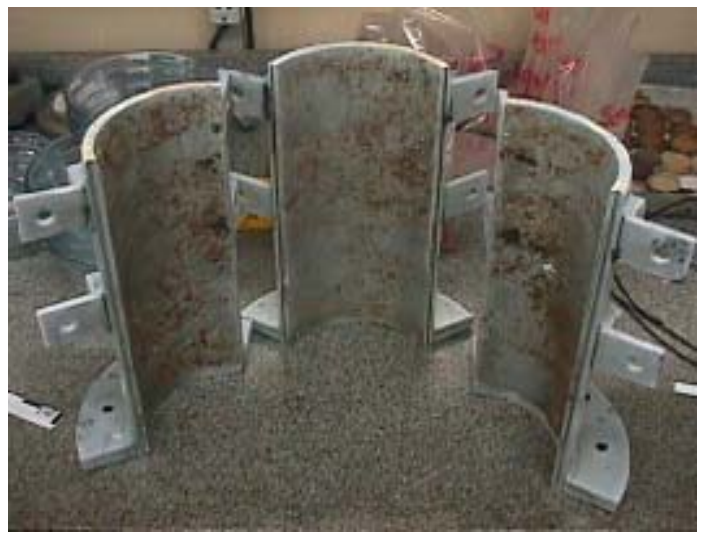

Figura 5.34: Cilindro tripartido desmontado

Para determinar a curva de compactação, foram testados quatro teores de umidade $8 \%, 10 \%, 12 \%$ e $14 \%$ - que foram selecionados com na absorção do agregado reciclado (cerca de $8 \%$ ), relatada no item 5.4.3.

Como a compactação foi realizada em um cilindro de dimensões diferenciadas, houve a necessidade de adaptação da energia necessária a ser aplicada, de forma que esta fosse equivalente à Proctor Intermediária. Os cálculos, que consideraram um maior número de camadas e menor número de golpes em relação à especificação, indicaram que o corpo-de-prova deveria ser preparado em 13 camadas com 25 golpes por camada; outro método utilizado foi o de reduzir o número de camadas, tendo em vista as elevadas dimensões dos agregados, e aumentar o número de golpes em cada uma delas, empregando-se neste caso 6 camadas com 57 golpes por camada. Ambas 
energias de compactação (mais camadas com menos golpes em cada uma e viceversa) são numericamente iguais.

Combinando-se os teores de umidade escolhidos ( $8 \%$ a 14\%) com as duas formas de moldagem citadas no parágrafo anterior, foi possível obter as curvas de compactação ilustradas na Figura 5.35.

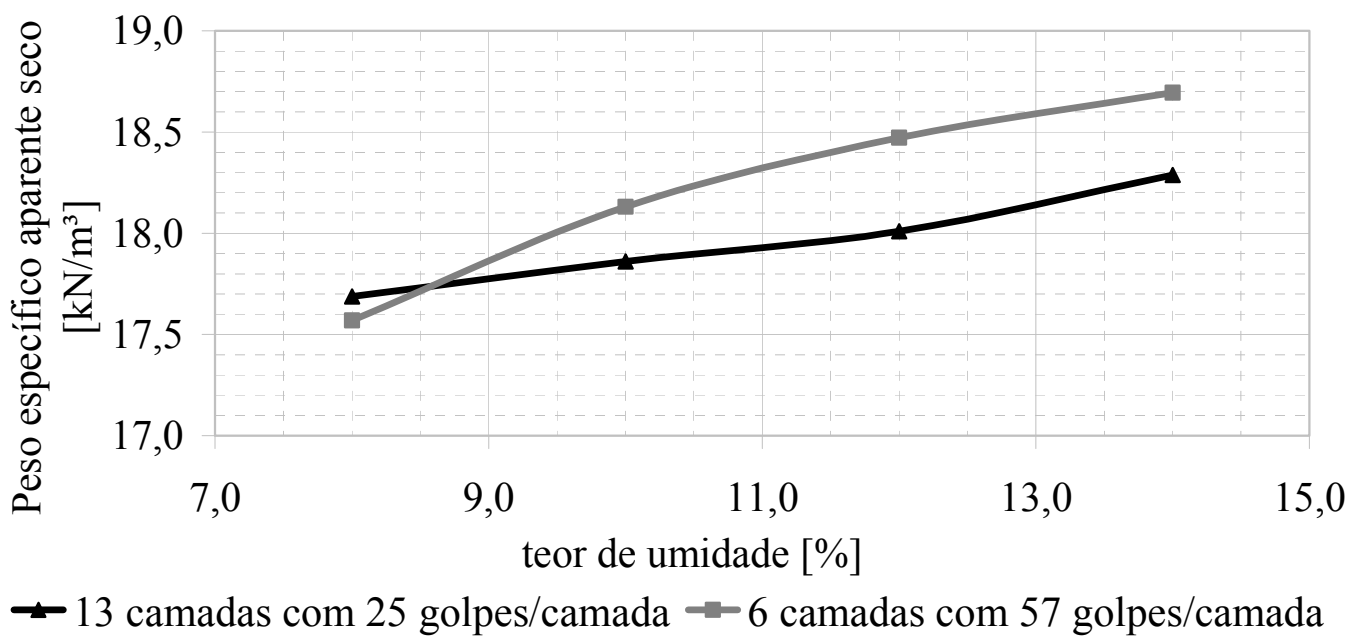

Figura 5.35: Curvas de compactação do agregado reciclado estudado

Embora a energia de compactação teórica seja aproximadamente a mesma nos dois casos apresentados no gráfico da Figura 5.35, a possibilidade de manutenção dos grãos maiores sem significativas quebras é observada no processo que envolve menor número de camadas, provavelmente devido à espessura destas.

Não se testou teores de umidade acima de $14 \%$, pois durante a preparação do material para a compactação observou-se a existência de água em excesso já na amostra com umidade de 12\% (na Figura 5.36 é possível observar a água em demasia na amostra com $14 \%$ de umidade). Há, na verdade, um escorrimento da água em excesso e o peso específico aparente seco se mantém praticamente o mesmo, já que o material está totalmente saturado. 


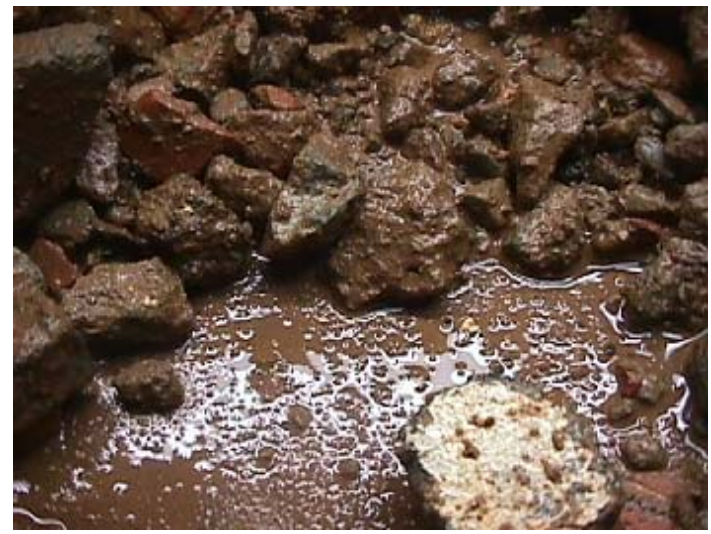

Figura 5.36: Água em excesso na preparação da amostra com umidade de 14\%

Em função disto, o teor de umidade de $11 \%$ se mostrou suficiente para a moldagem dos corpos-de-prova dos ensaios mecânicos, pois a mistura a ser compactada não apresentaria água em excesso.

Com a opção pelo teor de umidade de $11 \%$ e pela compactação em 6 camadas com 57 golpes em cada uma delas, observa-se na Figura 5.35 que o peso específico aparente seco do agregado reciclado estudado corresponde a aproximadamente $18,3 \mathrm{kN} / \mathrm{m}^{3}$.

A Tabela 5.5 apresenta os resultados obtidos nos ensaios de compactação em algumas pesquisas com diferentes tipos de agregado reciclado. 
Tabela 5.5: Teor de umidade ótima e peso específico aparente seco obtidos em algumas pesquisas

\begin{tabular}{|c|c|c|c|c|c|}
\hline $\begin{array}{l}\text { Tipo de } \\
\text { agregado } \\
\text { reciclado }\end{array}$ & Procedência & $\begin{array}{c}\text { Energia } \\
\text { Proctor } \\
\text { de } \\
\text { compactação }\end{array}$ & $\begin{array}{c}\text { Umidade } \\
\text { ótima } \\
{[\%]}\end{array}$ & $\begin{array}{c}\text { Peso } \\
\text { específico } \\
\text { aparente } \\
\text { seco } \\
{\left[\mathbf{k N} / \mathbf{m}^{3}\right]}\end{array}$ & Autor \\
\hline $\mathrm{C}^{(\mathrm{k})}$ & Suécia & Modificada & 9,4 & 20,0 & $\begin{array}{l}\text { Arm } \\
(2001)\end{array}$ \\
\hline $\mathrm{C}^{(\mathrm{k})}$ & Estados Unidos & Normal & 7,5 & 19,8 & $\begin{array}{l}\text { Bennert et al. } \\
\quad(2000)\end{array}$ \\
\hline $\mathrm{C}^{(\mathrm{k})}$ & Coréia do Sul & Normal & $12,1^{(p)}$ & $18,8^{(p)}$ & $\begin{array}{l}\text { Lim et al. } \\
\text { (2001) }\end{array}$ \\
\hline $\mathrm{V}^{(1)}$ & \multirow{2}{*}{$\begin{array}{l}\text { Florianópolis } \\
\text { (Brasil) }\end{array}$} & Normal & $12,0^{(q)}$ & $16,6^{(\mathrm{q})}$ & \multirow{2}{*}{$\begin{array}{l}\text { Trichês } \\
\text { e } \\
\text { Kryckyj } \\
\text { (1999) }\end{array}$} \\
\hline $\mathrm{B}^{(\mathrm{m})}$ & & Normal & $13,0^{(\mathrm{q})}$ & $17,5^{(\mathrm{q})}$ & \\
\hline $\mathrm{V}^{(1)}$ & \multirow{3}{*}{$\begin{array}{l}\text { São Paulo } \\
\text { (Brasil) }\end{array}$} & n.e. ${ }^{(0)}$ & 18,3 & 16,9 & \multirow{3}{*}{$\begin{array}{l}\text { Bodi et al. } \\
\text { (1995) }\end{array}$} \\
\hline $\mathrm{Mi}^{(\mathrm{n})}$ & & n.e. ${ }^{(o)}$ & 14,8 & 17,9 & \\
\hline $\mathrm{B}^{(\mathrm{m})}$ & & n.e. ${ }^{(0)}$ & 14,4 & 19,2 & \\
\hline $\mathrm{C}^{(\mathrm{k})}$ & \multirow{2}{*}{$\begin{array}{l}\text { Belo Horizonte } \\
\text { (Brasil) }\end{array}$} & Intermediária & 15,2 & 18,2 & \multirow{2}{*}{$\begin{array}{l}\text { Fernandes } \\
\text { (2004) }\end{array}$} \\
\hline $\mathrm{Mi}^{(\mathrm{n})}$ & & Intermediária & 17,0 & 17,6 & \\
\hline $\mathrm{V}^{(1)}$ & \multirow{3}{*}{$\begin{array}{l}\text { Goiás } \\
\text { (Brasil) }\end{array}$} & Intermediária & 26,0 & 14,2 & \multirow{3}{*}{$\begin{array}{l}\text { Ribeiro et al. } \\
\quad(2002)\end{array}$} \\
\hline $\begin{array}{l}50 \% \mathrm{~V}^{(\mathrm{l})} \\
50 \% \mathrm{~B}^{(\mathrm{m})}\end{array}$ & & Intermediária & 23,1 & 15,8 & \\
\hline $\mathrm{B}^{(\mathrm{m})}$ & & Intermediária & 18,2 & 17,6 & \\
\hline
\end{tabular}
(k) Concreto
${ }^{\left({ }^{\circ}\right)}$ não especificada
(1) Vermelho
(p) Valor médio
(m) Branco
(q) Valor aproximado
(n) Misto

Ao observar a Tabela 5.5, nota-se uma grande variação entre os valores obtidos de teor ótimo de umidade e de peso específico aparente seco para os diferentes tipos de agregados reciclados. Estas desigualdades podem ocorrer devido a fatores como composição ou tipo de agregado reciclado, energia de compactação utilizada, graduação do material ou ainda teor de umidade empregado. Assim, sugere-se neste trabalho que na determinação do teor de umidade, em termos práticos de compactação em campo, deve-se a priori definir o teor de absorção e, a partir daí, 
fazer ensaios de compactação, a despeito da curva, com atenção para a situação de água em excesso.

Complementarmente foi realizado um peneiramento após compactação e secagem do material de cada corpo-de-prova para verificar a variação de graduação sofrida pelo mesmo após o ensaio.

Da Figura 5.37 à Figura 5.40 são apresentadas as curvas granulométricas após compactação pelos dois processos (6 camadas com 57 golpes por camada e 13 camadas com 26 golpes por camada), na forma de porcentagens passantes (ou retidas), bem como de retidas não acumuladas.

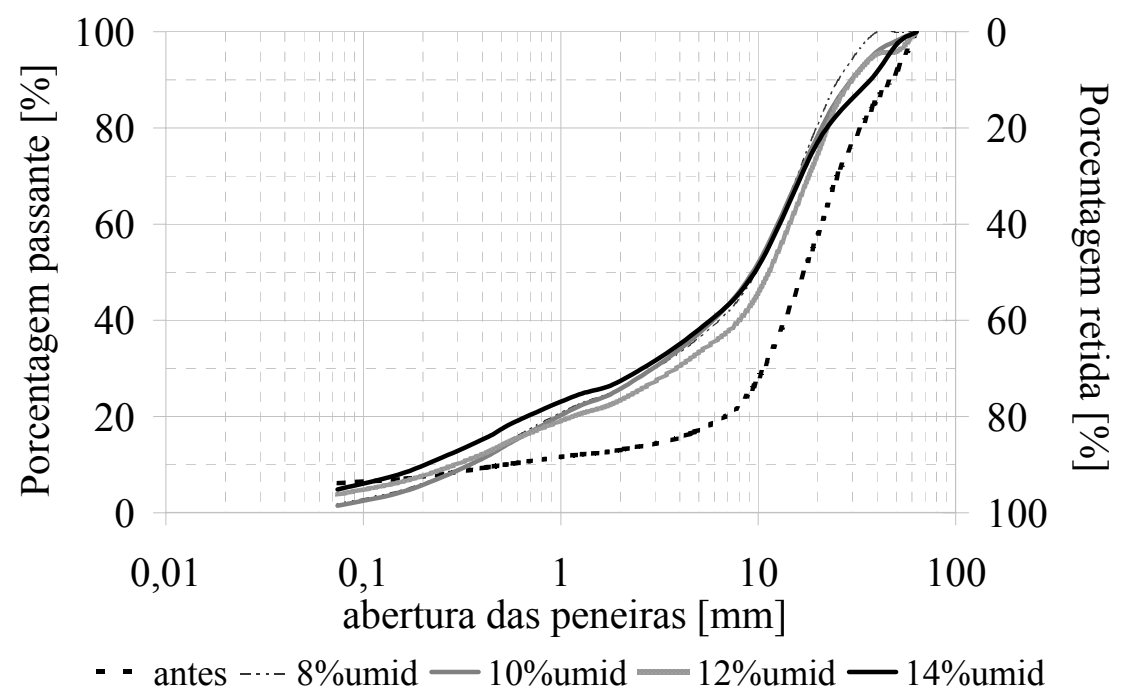

Figura 5.37: Variação granulométrica após compactação em 6 camadas e 57 golpes por camada, em função de porcentagens passantes (ou retidas) 


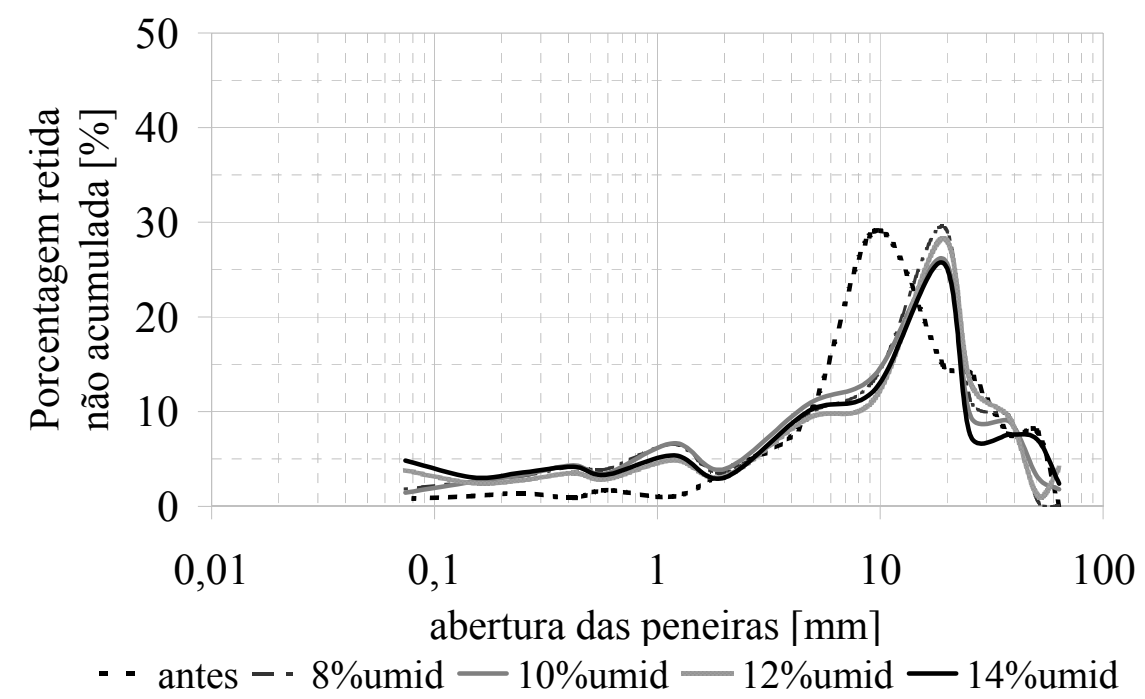

Figura 5.38: Variação granulométrica após compactação em 6 camadas e 57 golpes por camada, em função de porcentagens retidas não acumuladas

A Figura 5.37 e a Figura 5.38 mostram que a compactação em 6 camadas com a aplicação de 57 golpes em cada uma delas causou uma quebra de grãos muito significativa perante a curva inicial, implicando em uma notável variação da granulometria do material neste processo.

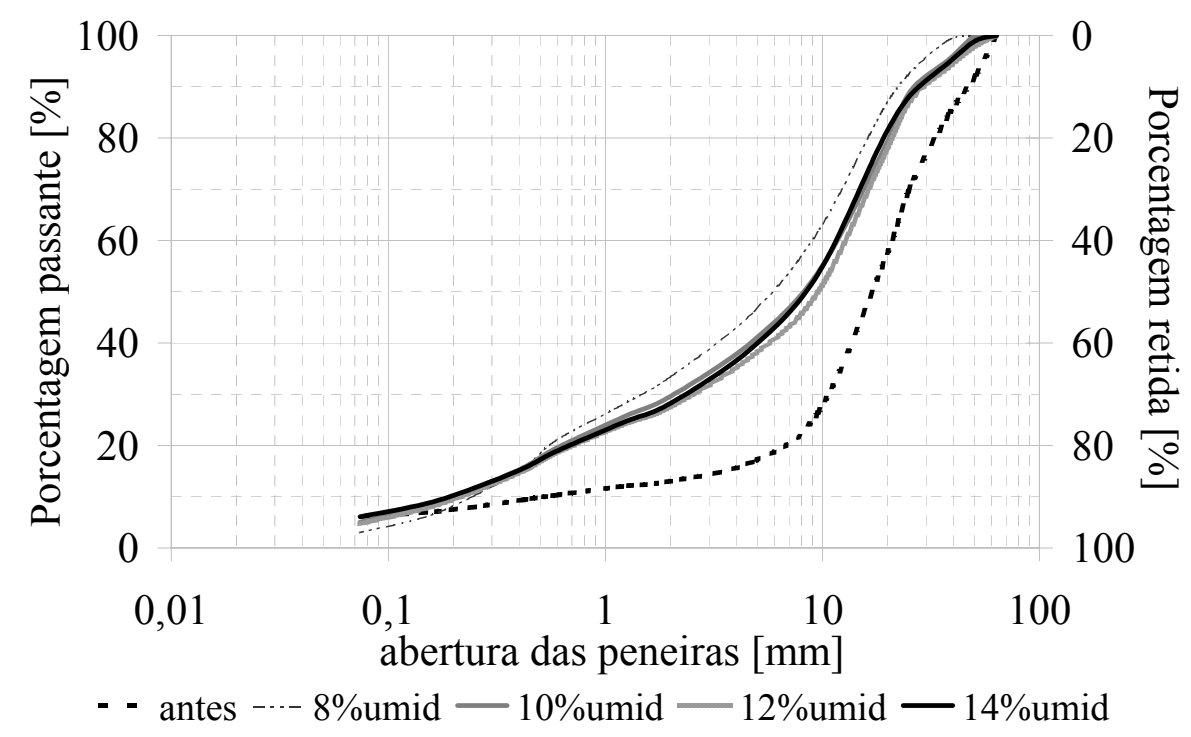

Figura 5.39: Variação granulométrica após compactação em 13 camadas e 26 golpes por camada, em porcentagens passantes (ou retidas) 


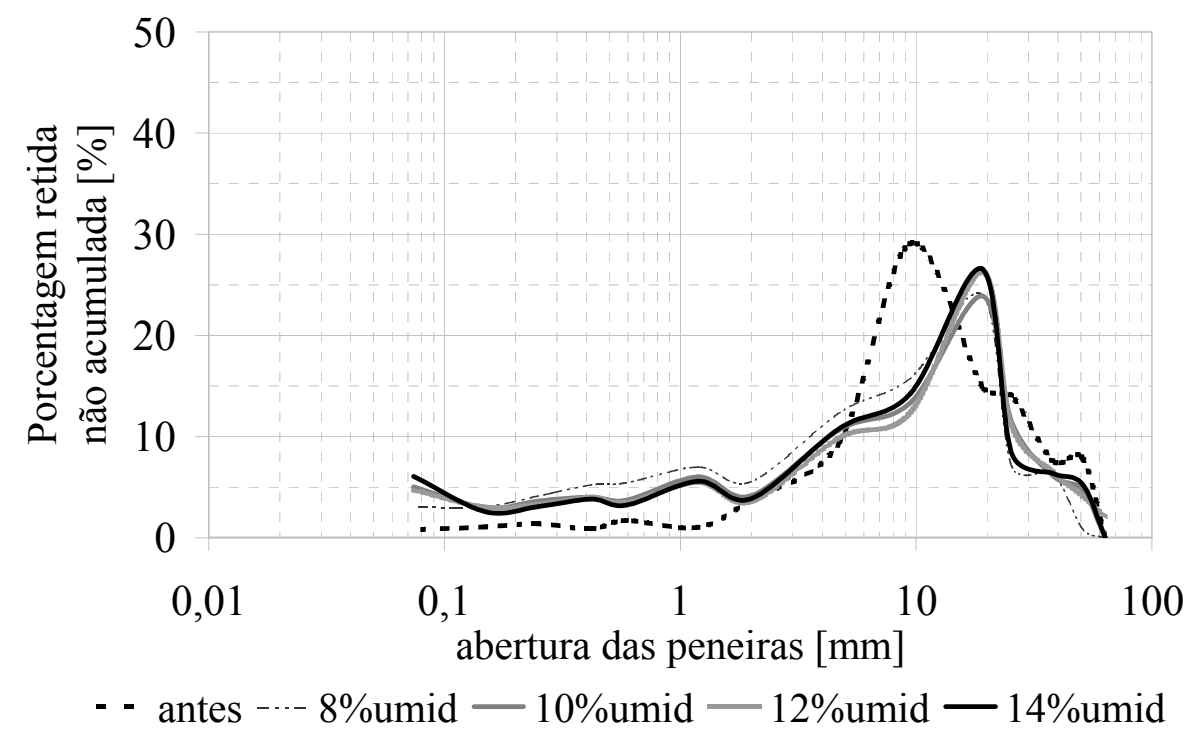

Figura 5.40: Variação granulométrica após compactação em 13 camadas e 26 golpes por camada, em função de porcentagens retidas não acumuladas

A Figura 5.39 e Figura 5.40 mostram que o processo de compactação em 13 camadas com 26 golpes em cada uma delas promoveu uma significativa quebra das partículas (assim como no caso anterior de menor número de camadas), se observada a curva granulométrica inicial. No entanto, ao se comparar a Figura 5.37 com a Figura 5.39, ou a Figura 5.38 com a Figura 5.40, percebe-se que a compactação em um maior número de camadas (13 ao invés de 6) foi mais agressiva, principalmente com umidade inferior à ótima e, conseqüentemente, implicou em maior quebra dos grãos.

Na Figura 5.39 (ou Figura 5.40), é possível notar que a compactação do material sob a condição de $8 \%$ de teor de umidade provocou uma maior quebra de grãos em relação às demais umidades estudadas, entre as peneiras $63,5 \mathrm{~mm}$ e $0,42 \mathrm{~mm}$. Isso talvez possa ser explicado pela lubrificação insuficiente dos grãos que, aliada à compactação no processo de 13 camadas delgadas com 26 golpes em cada uma delas, provocam uma tendência de quebra mais acentuada no caso das partículas maiores, com diâmetro equivalente entre $25,4 \mathrm{~mm}$ e $50,8 \mathrm{~mm}$.

Ainda na Figura 5.39 (ou Figura 5.40), exceto pelo teor de umidade de 8\%, verificase que a variação granulométrica imposta pela compactação entre as diferentes 
umidades testadas, em termos de porcentagens retidas ou passadas, não foi muito significativa.

De maneira geral, a compactação promoveu notáveis mudanças na granulometria do agregado reciclado, indiferentemente do teor de umidade utilizado (com exceção de $8 \%$ de umidade com a compactação em 13 camadas). Entretanto, o emprego de um menor número de camadas ( 6 ao invés de 13) fez com que essa variação fosse menor, evitando a quebra dos agregados de maior dimensão.

Como o agregado reciclado tende a sofrer uma expressiva alteração de granulometria em função da compactação (Figura 5.37 à Figura 5.40), em um extremo da análise, poder-se-ia dizer que ao longo do ensaio tem-se um material diferente e, teoricamente, não seria correta a união dos pontos para construção de uma curva como as que foram apresentadas na Figura 5.35.

\subsection{Variação do peso específico aparente seco com a energia de compactação}

Para contemplar a variação do peso específico aparente seco em função do incremento da energia de compactação, o agregado reciclado foi submetido à compactação no equipamento MCV (Moisture Condition Value), criado originalmente por Parsons em 1976 (Figura 5.41).

O equipamento utilizado nesta pesquisa (Figura 5.42) é uma adaptação do original, com diferenças no que tange a massa do soquete, que é igual a $4.536 \mathrm{~g}$ no adaptado ao invés dos $7.000 \mathrm{~g}$ proposto por Parsons, e a altura de queda livre, que é de $395 \mathrm{~mm}$ ao invés dos $300 \mathrm{~mm}$ originais para compensar o peso do soquete. $\mathrm{O}$ cilindro metálico possui as mesmas dimensões, ou $100 \mathrm{~mm}$ de diâmetro por $200 \mathrm{~mm}$ de altura e, da mesma forma, a compactação é feita por impacto com soquete que possui seção plena de 100mm. Rezende (1998) estudou detalhadamente o uso do equipamento MCV e sua adaptação para a pesquisa de solos concrecionados. 

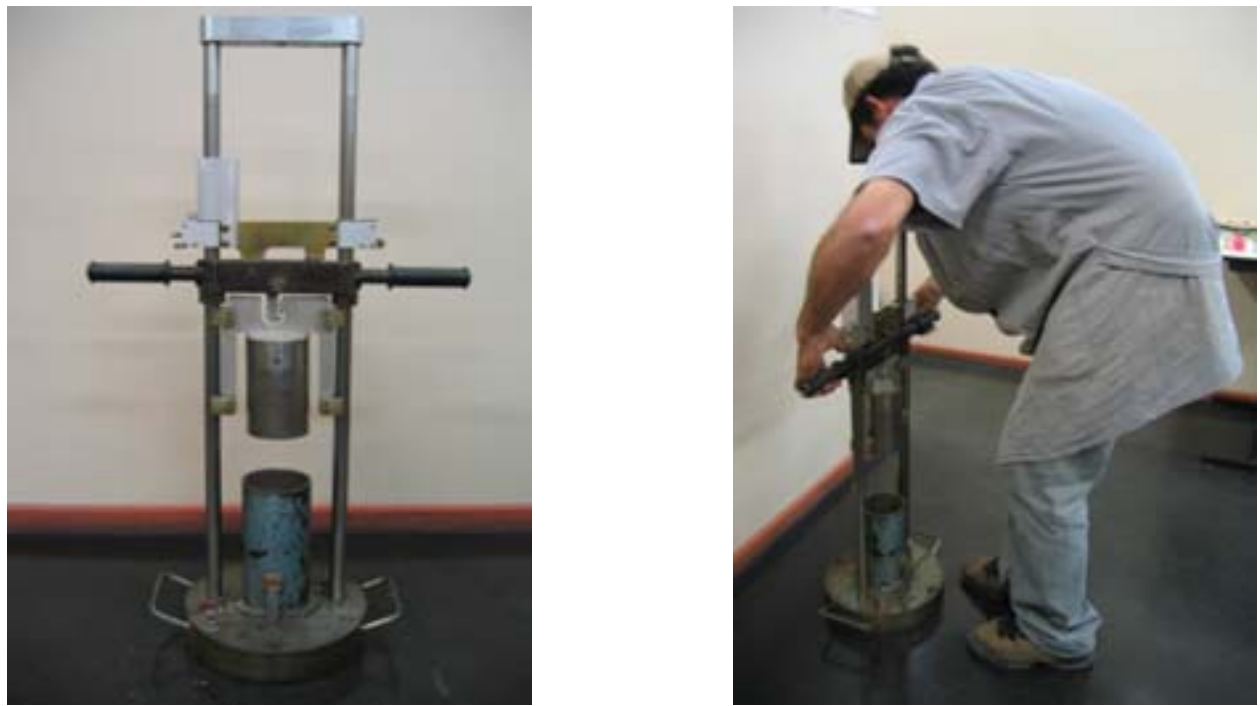

Figura 5.41: Equipamento MCV (criado por Parsons) do LTP-EPUSP
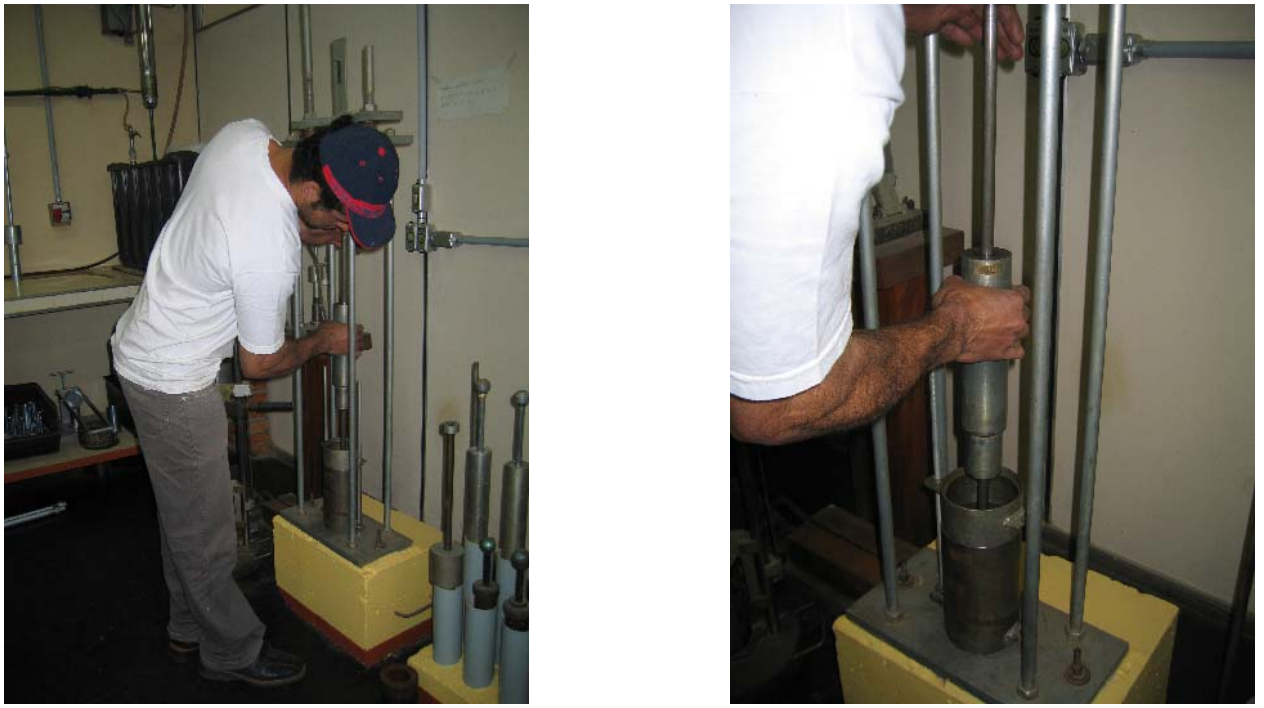

Figura 5.42: Compactação no equipamento MCV adaptado do LTP-EPUSP

Este ensaio mostra como ocorre a estabilização do material frente ao aumento de energia de compactação. De maneira geral, isto pode vir a indicar qual a energia de compactação necessária para que o valor do peso específico aparente seco se torne aproximadamente constante.

O conhecimento desta característica do material pode ser importante no entendimento de seu comportamento frente a uma real situação de campo, pois caso 
o peso específico aparente seco empregado na execução da obra não tenha sido o adequado, a ação do tráfego pode vir a causar deformação permanente no pavimento.

Basicamente, a seqüência de ensaio compreende a aplicação de um determinado número de golpes seguidos da leitura da altura do corpo-de-prova, e os valores obtidos permitem o cálculo do peso específico aparente seco para que seja delineada a curva deste em função do número de golpes.

Cabe ressaltar que foi empregado teor de umidade de $11 \%$ e que foi feita a substituição da parte graúda do material.

A Figura 5.43 apresenta a curva obtida de peso específico aparente seco por número de golpes.

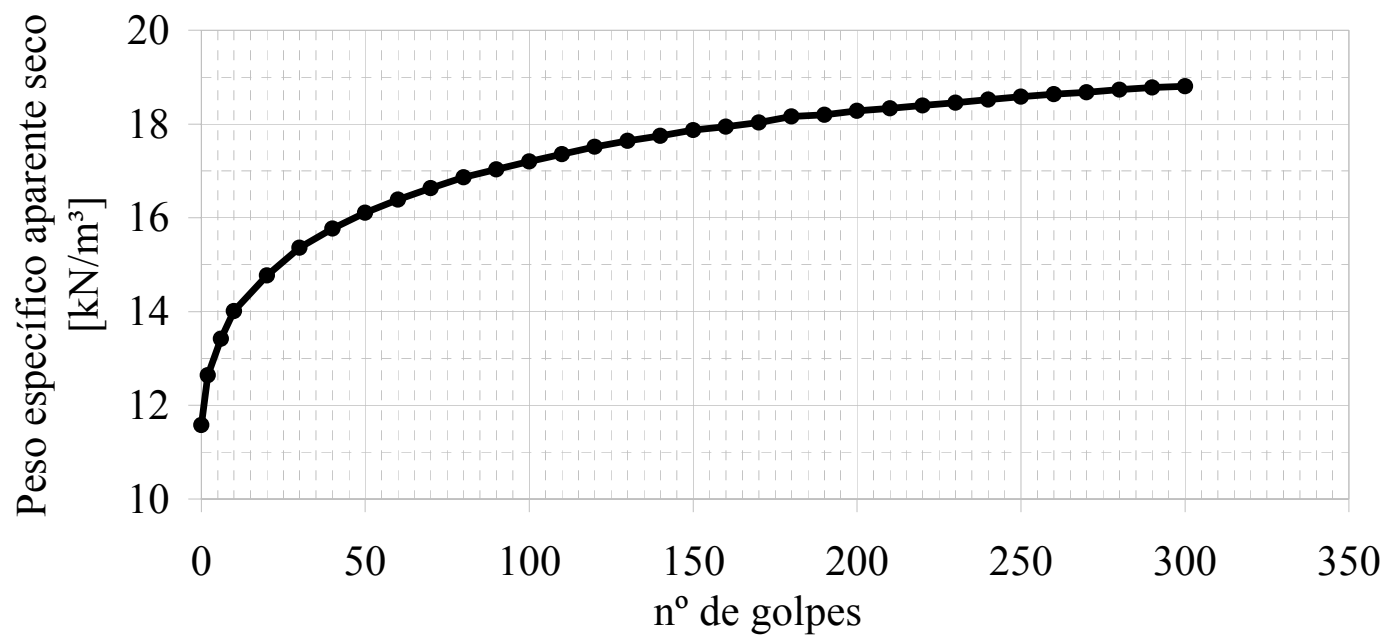

Figura 5.43: Variação do peso específico aparente seco em função da energia de compactação aplicada no ensaio com o equipamento MCV adaptado

Correlacionando-se o resultado de peso específico aparente seco deste ensaio com aquele obtido no experimento de determinação da curva de compactação, que para o teor de umidade de $11 \%$ foi de $18,3 \mathrm{kN} / \mathrm{m}^{3}$ (item 5.6), verifica-se que este valor equivale a 200 golpes na Figura 5.43. O efeito da compactação no MCV adaptado é diferente daquela realizada no Proctor em função do soquete, que no caso do equipamento $\mathrm{MCV}$ adaptado tem seção plena (igual dimensão do cilindro), provocando densificação por compressão e quebra; já no Proctor, como o soquete é 
menor, além de quebrar, a mobilidade de grãos é maior, vencendo mais facilmente a resistência ao cisalhamento e densificando com mais eficiência. Além disso, a compactação em camada única do MCV adaptado é menos eficiente que em várias camadas como no Proctor.

Posteriormente foi feita a análise da variação granulométrica do agregado reciclado com a compactação realizada neste ensaio. A Figura 5.44 e a Figura 5.45 apresentam a granulometria do material antes e depois da compactação, em função de porcentagens passantes (ou retidas) e de porcentagens retidas não acumuladas, respectivamente.

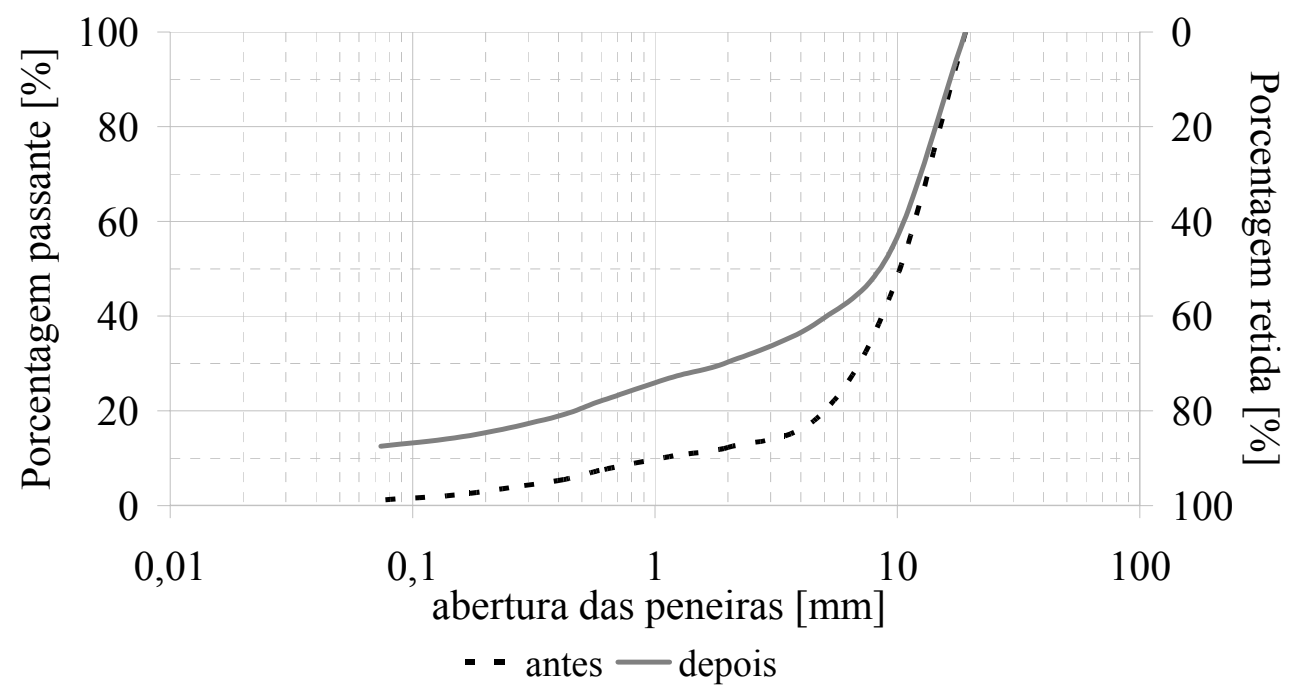

Figura 5.44: Variação granulométrica após compactação no MCV adaptado, em função de porcentagens passantes (ou retidas) 


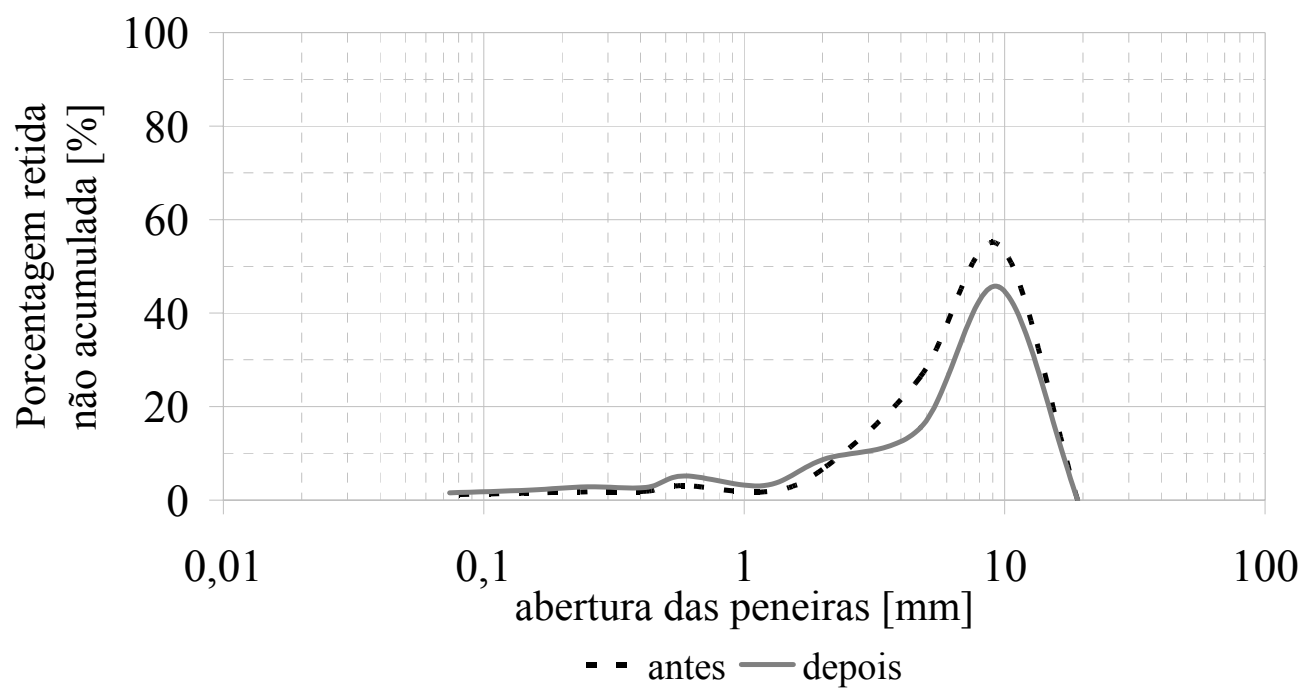

Figura 5.45: Variação granulométrica após compactação no MCV adaptado, em função de porcentagens retidas não acumuladas

É possível notar na Figura 5.44 e na Figura 5.45 que as maiores diferenças ocorreram no trecho entre as peneiras $1,19 \mathrm{~mm}$ e $4,76 \mathrm{~mm}$, onde a quebra de grãos promoveu, principalmente, a formação de fração areia.

\subsection{Caracterização do comportamento mecânico}

Os ensaios tecnológicos de avaliação das propriedades mecânicas dos materiais de engenharia procuram simular as condições reais de solicitação no campo (MEDINA, 1997), daí a importância de realizá-los, a fim de se conhecer as características dos materiais empregados, bem como de otimizar a vida útil de um pavimento.

Nesta pesquisa, a caracterização mecânica do agregado reciclado envolveu os seguintes ensaios:

- Índice de Suporte Califórnia (ISC);

- Resistência à Compressão Simples (RCS);

- Resistência à Tração por Compressão Diametral (RTCD);

- Módulo de Resiliência (MR).

Para estes experimentos foram moldados 80 corpos-de-prova, sendo 33 para Módulo de Resiliência e Resistência à Compressão Simples (29 para ambos e mais 4 só para 
RCS); 39 para Resistência à Tração por Compressão Diametral; e 8 para Índice de Suporte Califórnia.

$\mathrm{Na}$ compactação dos corpos-de-prova empregou-se teor de umidade de 11\% (valor determinado no item 5.6), soquete Proctor grande de 4.536g, altura de queda de 457mm e energia Proctor Intermediária.

Os corpos-de-prova que seriam submetidos aos ensaios de ISC e RTCD foram moldados em cilindros de $152 \mathrm{~mm}$ por $178 \mathrm{~mm}$, enquanto que aqueles que seriam destinados aos experimentos de RCS e MR foram compactados em cilindro de $150 \mathrm{~mm}$ por $300 \mathrm{~mm}$.

A moldagem de corpos-de-prova em cilindro de $150 \mathrm{~mm}$ por $300 \mathrm{~mm}$ para ensaio de Módulo de Resiliência também foi adotada por Bennert et al. (2000), Arm (2001) e Hill et al. (2001).

A compactação em cilindro de $152 \mathrm{~mm}$ por $178 \mathrm{~mm}$ gera corpos-de-prova com altura total de $125 \mathrm{~mm}$.

Em virtude da dimensão característica máxima do agregado reciclado estudado $(63,5 \mathrm{~mm})$, houve necessidade de substituição da parte graúda do material quando da compactação em cilindro de $152 \mathrm{~mm}$ por $178 \mathrm{~mm}$.

Para que fosse verificado o uso de energia Proctor Intermediária, a moldagem foi realizada em 6 camadas com 26 golpes por camada no caso de cilindro de $152 \mathrm{~mm}$ por $178 \mathrm{~mm}$, e em 6 camadas com 57 golpes por camada no caso de cilindro de $150 \mathrm{~mm}$ por $300 \mathrm{~mm}$.

Para os ensaios mecânicos (exceto para ISC), foram confeccionados 3 tipos de corpos-de-prova: in natura (ou seja, agregado reciclado sem a adição de outro 
componente), agregado reciclado com a adição de $4 \%$ de cal ${ }^{(25)}$ e agregado reciclado com a adição de $4 \%$ de cimento Portland ${ }^{(26)}$.

A inclusão de cal ou cimento Portland foi feita imediatamente antes do processo de compactação. O agregado reciclado, previamente submetido ao teor de umidade de $11 \%$, foi pulverizado uniformemente com a cal ou com o cimento Portland e, em seguida, revolvido para homogeneizar o conjunto.

O emprego de cal ou cimento Portland na preparação dos corpos-de-prova foi feito tendo-se em vista seu potencial aglomerante, capaz de provocar uma alteração das propriedades mecânicas do agregado reciclado. Esta alteração se traduz num aumento da resistência do material, devido à ocorrência de reação pozolânica após determinado período de cura. Hill et al. (2001), que analisaram agregados reciclados misturados a cimento, concluíram que houve aumento da resistência do material com o tempo, podendo ser verificado após vários meses.

Tendo-se em vista a cura do material, é importante salientar que corpos-de-prova do tipo in natura também foram submetidos aos mesmos períodos de cura das misturas com cal e cimento Portland para avaliar se partículas não inertes contidas no agregado reciclado promoveriam reações pozolânicas e, com isto, aumentariam a resistência do material de maneira significativa. Bodi et al. (1995) citam que o agregado reciclado possui cimentos e cales ainda ativos que fazem com que haja um aumento da coesão da mistura.

Os diferentes tempos de cura a que os corpos-de-prova foram submetidos são apresentados na Tabela 5.6.

${ }^{(25)}$ Cal tipo Supercal CH-I da Ical

(26) Cimento Portland tipo CPII E 32 da Votoran 
Tabela 5.6: Tempos de cura empregados

\begin{tabular}{|c||c||c|}
\hline $\begin{array}{c}\text { Tipo de } \\
\text { ensaio }\end{array}$ & $\begin{array}{c}\text { Tipo de } \\
\text { corpo-de-prova }\end{array}$ & $\begin{array}{c}\text { Tempo de cura } \\
\text { [dias] }\end{array}$ \\
\hline Índice de Suporte Califórnia & in natura & $0,28,90,180$ \\
\hline \multirow{2}{*}{$\begin{array}{c}\text { Resistência à Tração } \\
\text { por Compressão Diametral }\end{array}$} & in natura & $0,28,90,180$ \\
\cline { 2 - 3 } & com cal & $7,28,90,180$ \\
\hline \multirow{2}{*}{ Resistência à Compressão Simples } & in natura & $0,28,90,180$ \\
\cline { 2 - 3 } & com cal & $7,28,90,180$ \\
\cline { 2 - 3 } & com cimento Portland & $7,28,90,180$ \\
\hline \multirow{2}{*}{ Módulo de Resiliência } & in natura & $0,28,90,180$ \\
\cline { 2 - 3 } & com de cal & $28,90,180$ \\
\cline { 2 - 3 } & com cimento Portland & $28,90,180$ \\
\hline
\end{tabular}

Para que os corpos-de-prova não sofressem desagregação de sua estrutura por ocasião do armazenamento, os mesmos foram envolvidos por um tubo de PVC (Figura 5.46), com exceção daqueles compactados para o ensaio de ISC que foram mantidos em seus moldes metálicos.
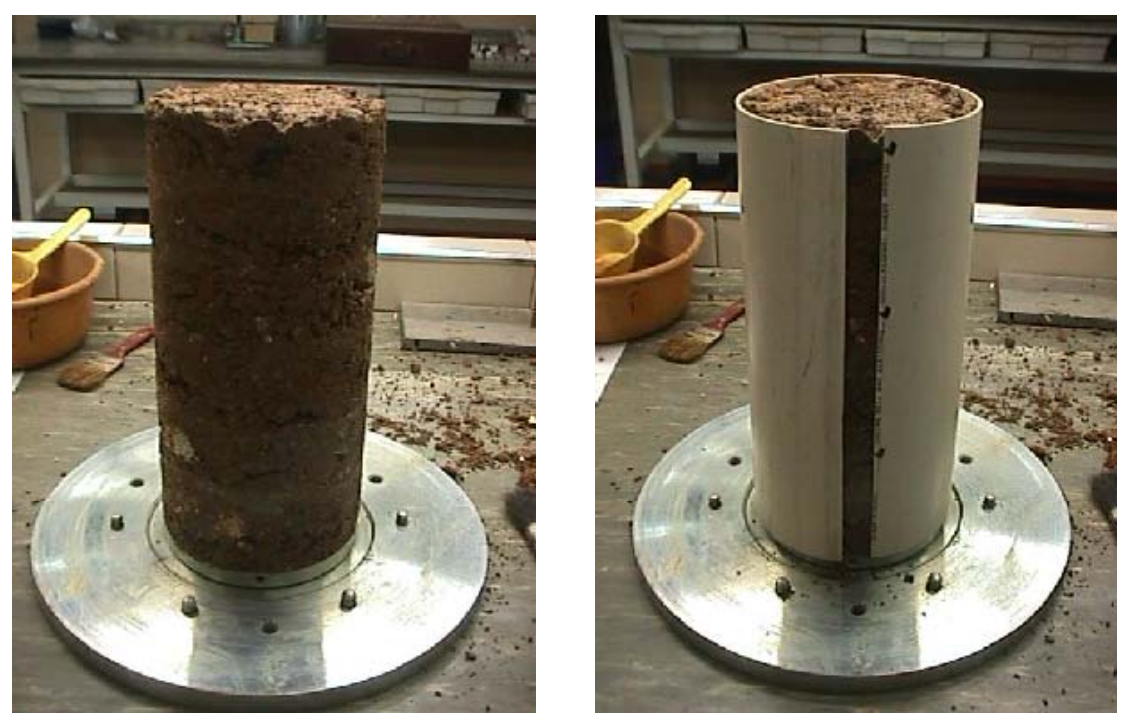

Figura 5.46: Colocação de tubo de PVC para que houvesse sustentação do corpo-deprova durante o período de cura

Nos corpos-de-prova com os quais seriam realizados ensaios de Módulo de Resiliência moldou-se finas camadas de gesso em suas extremidades superiores (Figura 5.47) para regularizar a superfície e assim promover uma leitura mais precisa 
dos deslocamentos obtidos no experimento. Este procedimento é usual no LTPEPUSP com materiais granulares ou solo-brita.

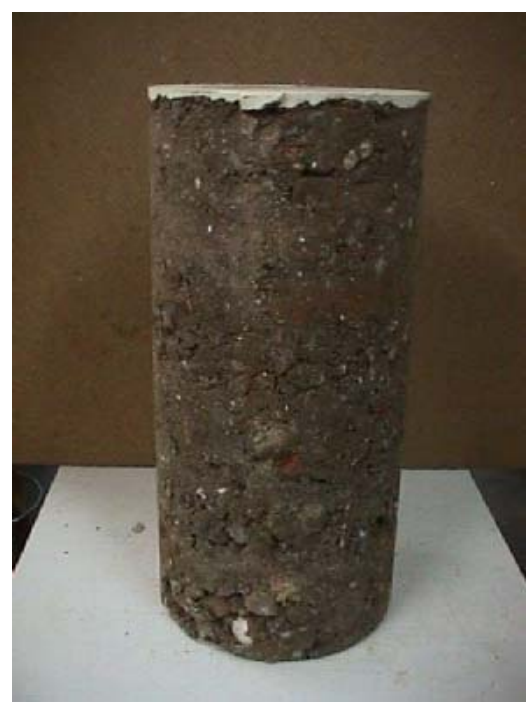

Figura 5.47: Corpo-de-prova de agregado reciclado recoberto por fina camada de gesso em sua extremidade superior

Para cumprir os períodos de cura estipulados, os corpos-de-prova foram armazenados em uma caixa preenchida com serragem úmida, para que não houvesse perda de umidade neste processo (Figura 5.48).

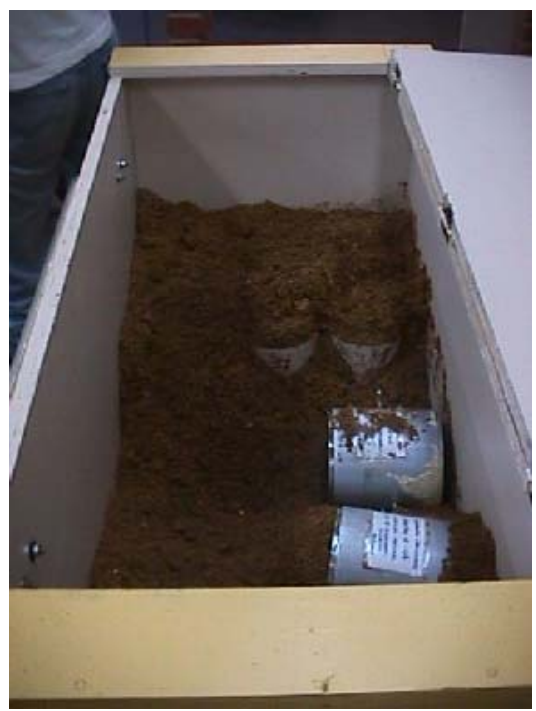

Figura 5.48: Armazenamento dos corpos-de-prova em caixa com serragem umedecida 


\subsection{1 Índice de Suporte Califórnia (ISC)}

A concepção do ensaio de Índice de Suporte Califórnia, também chamado de CBR (California Bearing Ratio), teve como objetivo principal definir a resistência ou valor de suporte dos materiais granulares empregados em pavimentação.

Entretanto, os ensaios estáticos (como o de ISC) não devem ser os únicos para prever o comportamento de solos e agregados, uma vez que estes são submetidos a cargas repetidas devido à ação do tráfego. As magnitudes de deslocamentos frente ao carregamento no experimento de ISC são, em geral, muito maiores que aquelas verificadas no ensaio de Módulo de Resiliência (que é um ensaio dinâmico).

De qualquer forma, o experimento de ISC é um dos mais difundidos no meio rodoviário brasileiro, e consta na norma NBR 15115 (2004) como item necessário a ser verificado quando do uso de agregado reciclado de resíduo de construção em pavimentação.

O ensaio de ISC foi realizado de forma similar ao especificado pela DNER-ME 049/94 (1994). De maneira geral, o mesmo consiste na aplicação de um carregamento estático em um corpo-de-prova sob condição saturada. Basicamente são observadas três fases, sendo elas: moldagem do corpo-de-prova (Figura 5.49); imersão do corpo-de-prova em água destilada (Figura 5.50) por um período de quatro dias (que permite a verificação da expansão do material); e penetração no corpo-deprova de um pistão de diâmetro padronizado, em velocidade constante, acompanhado de registro das cargas de reação por meio de um anel dinamométrico acoplado à prensa (Figura 5.51). 

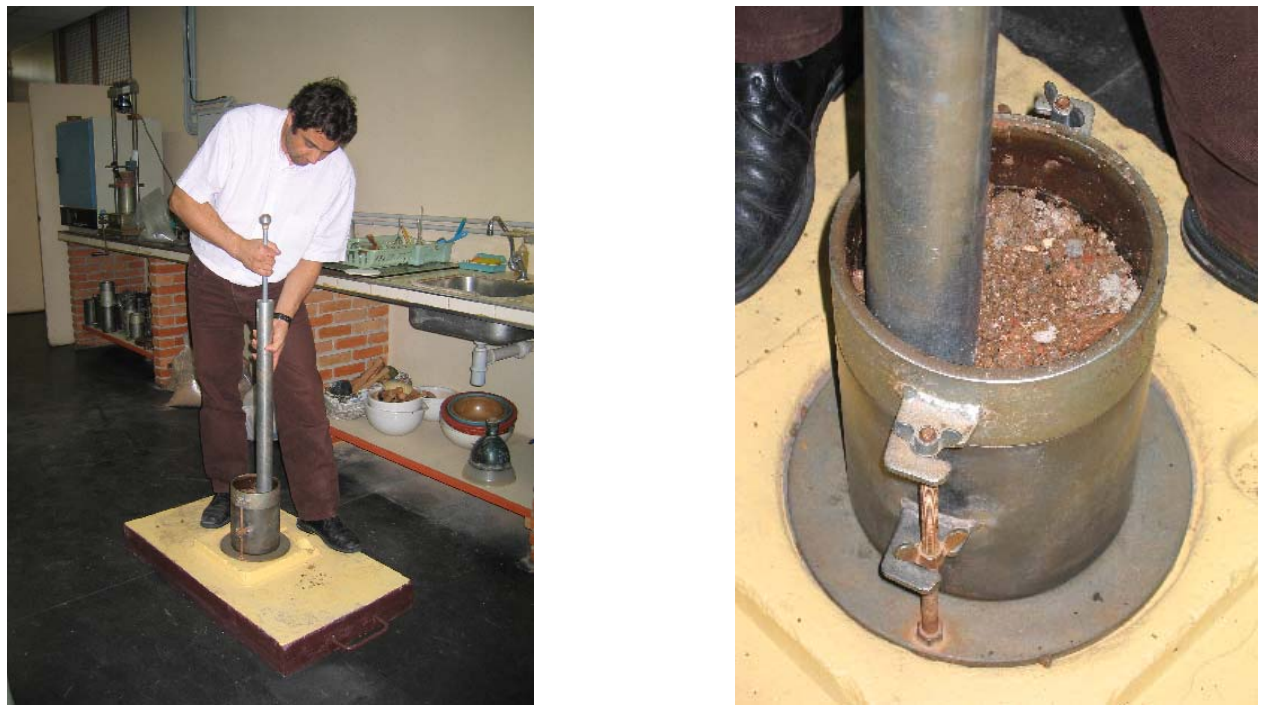

Figura 5.49: Compactação do corpo-de-prova para ensaio de ISC

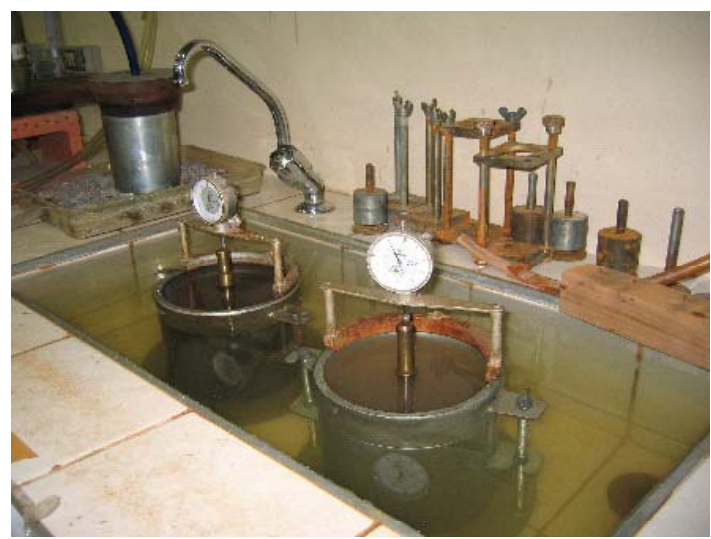

Figura 5.50: Imersão dos corpos-de-prova em água destilada

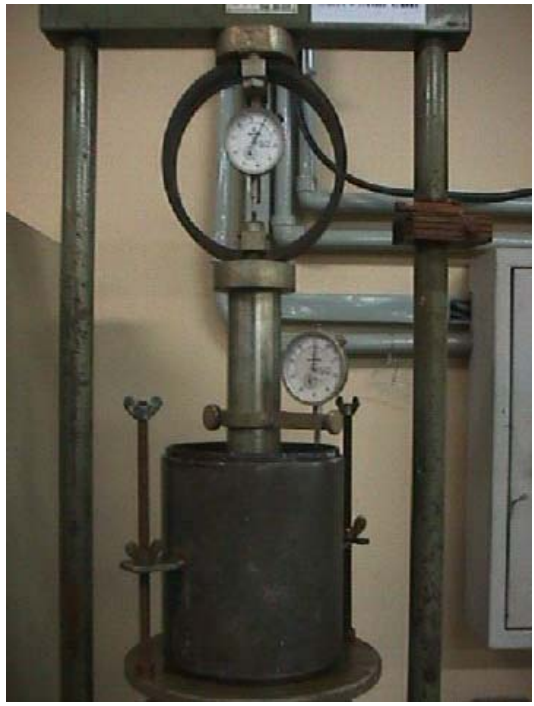

Figura 5.51: Prensa para ISC

A moldagem pode ser feita em equipamento mecanizado (Figura 5.52) e a penetração em prensa automatizada (esta última não disponível no LTP-EPUSP). 


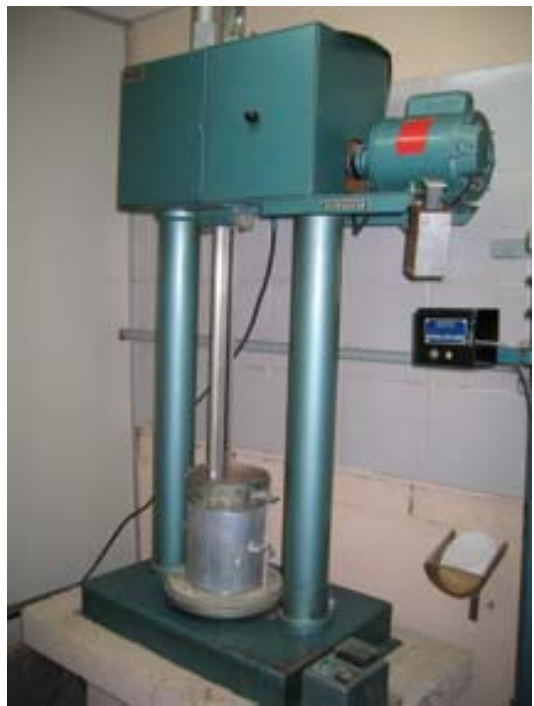

Figura 5.52: Compactador mecânico do LTP-EPUSP

Para esta pesquisa foram ensaiados 8 corpos-de-prova, cujos resultados são apresentados na Figura 5.53 e na Tabela 5.7. Na Figura 5.53, os pontos representam os valores de ISC obtidos e a curva demonstra a progressão do ISC com base em números médios.

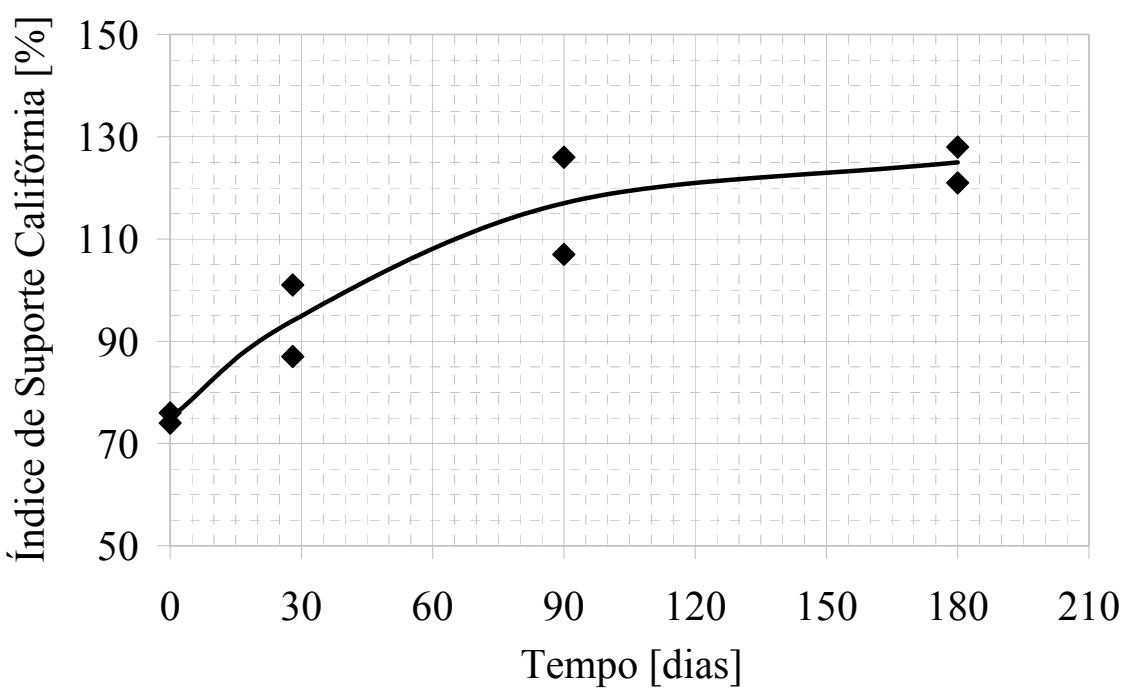

Figura 5.53: Resultado dos ensaios de Índice de Suporte Califórnia 
Tabela 5.7: Resultado dos ensaios de Índice de Suporte Califórnia

\begin{tabular}{|c||c|}
\hline $\begin{array}{c}\text { Tempo de cura } \\
\text { [dias] }\end{array}$ & $\begin{array}{c}\text { Índice de Suporte Califórnia } \\
{[\%]}\end{array}$ \\
\hline 0 & 76 \\
\hline 0 & 74 \\
\hline 28 & 87 \\
\hline 28 & 101 \\
\hline 90 & 126 \\
\hline 90 & 107 \\
\hline 180 & 121 \\
\hline 180 & 128 \\
\hline
\end{tabular}

Com base nos dados apresentados pela Figura 5.53, nota-se alguma dispersão dos resultados de 28 e também de 90 dias, talvez relacionada à heterogeneidade do agregado reciclado, ou ainda à possibilidade de erro inerente ao ensaio.

Verifica-se que houve aumento significativo do valor de suporte do material com o tempo de cura: tomando-se como parâmetro de comparação a curva média, verificase que o ISC aos 28, 90 e 180 dias de cura cresceram cerca de $24 \%, 55 \%$ e $67 \%$, respectivamente, em relação ao resultado obtido sem cura prévia (aos zero dias).

Como a análise trata de agregado reciclado sem a adição de material com potencial aglomerante (cal ou cimento Portland), então há indícios de que houve reação pozolânica por parte de partículas que ainda possuíam potencial reativo, provocada pela adição de água para atingir o teor de umidade e pela compactação (que aumenta a finura do material), segundo princípios descritos no item 5.4.4.

Verifica-se que após 90 dias os valores de ISC já ultrapassam a marca dos 100\%, e isto indica que o agregado reciclado estudado possuía nestas condições uma capacidade de suporte maior do que a da brita-padrão, que foi a referência quando da concepção do ensaio.

Em termos de expansão, o valor apresentado por todos os corpos-de-prova foi nulo. Esse resultado se deu de forma semelhante em outras pesquisas: Trichês e Kryckyj (1999) citam que o agregado reciclado apresentou expansibilidade nula em sua 
pesquisa; Bodi et al. (1995) verificaram fraca atividade expansiva do material, sendo o valor encontrado da ordem de 0,01\%; Carneiro et al. (2001) observaram expansão praticamente nula em estudo com a fração graúda e miúda de agregado reciclado; e Ribeiro et al. (2002) também constataram que o agregado reciclado apresentou valores de expansão próximos a zero.

Nas três primeiras pesquisas relacionadas no parágrafo anterior também foram estudadas misturas de diferentes tipos de solo com o agregado reciclado e, em todos os casos, notou-se que a incorporação de agregado reciclado ao solo diminui sensivelmente a expansibilidade deste último.

Os resultados de ISC encontrados neste estudo, aproximadamente entre $75 \%$ e $125 \%$ (em valores médios), além de expansão igual a $0 \%$, satisfazem a especificação NBR 15115 (2004), cujos limites são apresentados na Tabela 5.8. Isto significa que, no que se refere à capacidade de suporte e expansão, o agregado reciclado estudado poderia ser empregado em reforço do subleito, sub-base e até mesmo como base de um pavimento (neste último caso, de baixo volume de tráfego).

Tabela 5.8: Limites de ISC e expansão especificados pela NBR 15115 (2004)

\begin{tabular}{|c||c|c||c||}
\hline $\begin{array}{c}\text { Tipo } \\
\text { de camada }\end{array}$ & $\begin{array}{c}\text { ISC } \\
{[\%]}\end{array}$ & $\begin{array}{c}\text { Expansão } \\
{[\%]}\end{array}$ & $\begin{array}{c}\text { Energia Proctor } \\
\text { de compactação }\end{array}$ \\
\hline Reforço do subleito & $\geq 12$ & $\leq 1,0$ & Normal ou superior \\
\hline Sub-base & $\geq 20$ & $\leq 1,0$ & Intermediária \\
\hline Base $^{(\mathrm{r})}$ & $\geq 60$ & $\leq 0,5$ & Intermediária \\
\hline
\end{tabular}

(r) Permitido o uso neste caso somente para vias de baixo volume de tráfego (que é o foco deste trabalho), com número de repetições do eixo padrão de $80 \mathrm{kN}$ inferior a $10^{6}$

Alguns pesquisadores estrangeiros também realizaram ensaios para determinar o ISC de agregados reciclados, tanto em laboratório quanto em campo, sendo alguns dos resultados apresentados na Tabela 5.9. 
Tabela 5.9: ISC de agregados reciclados obtidos em algumas pesquisas realizadas em outros países

\begin{tabular}{|c|c|c|c|c|c|}
\hline $\begin{array}{c}\text { Tipo de } \\
\text { agregado } \\
\text { reciclado }\end{array}$ & Procedência & $\begin{array}{c}\text { Energia } \\
\text { Proctor } \\
\text { de } \\
\text { compactação }\end{array}$ & $\begin{array}{c}\text { Umidade } \\
\text { ótima } \\
{[\%]}\end{array}$ & $\begin{array}{c}\text { Índice de } \\
\text { Suporte } \\
\text { Califórnia } \\
{[\%]}\end{array}$ & Autor \\
\hline $\mathrm{C}$ e $\mathrm{B}^{(\mathrm{s})}$ & $\begin{array}{l}\text { Hong Kong } \\
\text { China }\end{array}$ & n.e. ${ }^{(v)}$ & n.e. ${ }^{(v)}$ & 39 & $\begin{array}{l}\text { Poon } \\
\text { (1997) }\end{array}$ \\
\hline $\mathrm{C}^{(\mathrm{t})}$ & \multirow{2}{*}{$\begin{array}{c}\text { Nova Gales do Sul } \\
\text { Austrália }\end{array}$} & Normal & \multirow{2}{*}{ n.e. ${ }^{(v)}$} & $68^{(\mathrm{w})}$ & \multirow{2}{*}{$\begin{array}{l}\text { UTS } \\
(1999)\end{array}$} \\
\hline $\mathrm{C}^{(\mathrm{t})}$ & & Modificada & & $115^{(\mathrm{w})}$ & \\
\hline$C^{(t)}$ & $\begin{array}{c}\text { Taejon } \\
\text { Coréia do Sul }\end{array}$ & Normal & 12,1 & $88^{\text {(w) }}$ & $\begin{array}{l}\text { Lim et al. } \\
\text { (2001) }\end{array}$ \\
\hline $\mathrm{D}^{(\mathrm{u})}$ & Reino Unido & n.e. ${ }^{(v)}$ & natural & $66^{(\mathrm{x})}$ & \multirow{3}{*}{$\begin{array}{l}\text { Reid } \\
(2000)\end{array}$} \\
\hline $\mathrm{C}^{(\mathrm{t})}$ & Dinamarca & n.e. ${ }^{(v)}$ & natural & $120^{(\mathrm{x})}$ & \\
\hline $\mathrm{C}^{(\mathrm{t})}$ & Suécia & n.e. ${ }^{(v)}$ & natural & $245^{(\mathrm{x})}$ & \\
\hline
\end{tabular}

${ }^{\text {(s) }}$ Concreto e brita principalmente, com pequena parcela de solo e areia

(t) Concreto

(u) Demolição

(v) não especificada

${ }^{(\mathrm{w})}$ Valor médio

${ }^{(\mathrm{x})}$ Valores de campo obtidos por meio de FWD (Falling Weigh Deflectometer)

É possível observar na Tabela 5.9 que houve grande variação entre as porcentagens de ISC apresentadas pelos diversos autores, embora deva-se ressaltar que os valores de ISC assinalados na tabela como (x) são resultados de ensaios de campo, obtidos por meio de FWD (Falling Weight Deflectometer). Reid (2000) menciona que nas pesquisas com agregados reciclados (e ainda com outros tipos de materiais reciclados), o desempenho de campo chegou a ser melhor em alguns casos do que teria sido previsto em laboratório.

No Brasil também foram realizados experimentos para determinação do ISC de agregados reciclados, cujos resultados são apontados na Tabela 5.10. Verifica-se que existem significativas diferenças entre os mesmos, possivelmente devido a fatores como composição ou tipo de agregado reciclado, graduação, energia de compactação empregada ou teor de umidade. 
Tabela 5.10: ISC de agregados reciclados obtidos em algumas pesquisas brasileiras

\begin{tabular}{|c|c|c|c|c|c|}
\hline $\begin{array}{c}\text { Tipo de } \\
\text { agregado } \\
\text { reciclado }\end{array}$ & Procedência & $\begin{array}{c}\text { Energia } \\
\text { Proctor } \\
\text { de } \\
\text { compactação }\end{array}$ & $\begin{array}{c}\text { Umidade } \\
\text { ótima } \\
{[\%]}\end{array}$ & $\begin{array}{c}\text { Índice de } \\
\text { Suporte } \\
\text { Califórnia } \\
{[\%]}\end{array}$ & Autor \\
\hline $\mathrm{V}^{(\mathrm{y})}$ & \multirow{2}{*}{$\begin{array}{c}\text { Santa Catarina } \\
\text { (SC) }\end{array}$} & \multirow{2}{*}{ Normal } & $12^{(\mathrm{cc})}$ & \multirow{2}{*}{24 a $30^{(\mathrm{cc})}$} & \multirow{2}{*}{$\begin{array}{l}\text { Trichês } \\
\text { e } \\
\text { Kryckyj } \\
\text { (1999) }\end{array}$} \\
\hline $\mathrm{B}^{(\mathrm{z})}$ & & & $13^{(\mathrm{cc})}$ & & \\
\hline $\mathrm{V}^{(\mathrm{y})}$ & \multirow{3}{*}{$\begin{array}{l}\text { Goiânia } \\
\text { (GO) }\end{array}$} & Intermediária & 26,0 & 42 & \multirow{3}{*}{$\begin{array}{l}\text { Ribeiro et al. } \\
\text { (2002) }\end{array}$} \\
\hline $\begin{array}{l}50 \% \mathrm{~V}^{(\mathrm{y})} \\
50 \% \mathrm{~B}^{(\mathrm{z})}\end{array}$ & & Intermediária & 23,1 & 52 & \\
\hline $\mathrm{B}^{(\mathrm{z})}$ & & Intermediária & 18,2 & 62 & \\
\hline $\mathrm{V}^{(\mathrm{y})}$ & \multirow{3}{*}{$\begin{array}{l}\text { São Paulo } \\
\quad \text { (SP) }\end{array}$} & n.e. ${ }^{(b b)}$ & 18,3 & 63 & \multirow{3}{*}{$\begin{array}{l}\text { Bodi et al. } \\
\text { (1995) }\end{array}$} \\
\hline $\mathrm{Mi}^{(\mathrm{aa})}$ & & n.e. ${ }^{(b b)}$ & 14,8 & 98 & \\
\hline $\mathrm{B}^{(\mathrm{z})}$ & & n.e. ${ }^{(b b)}$ & 14,4 & 111 & \\
\hline$n \cdot e^{(b b)}$ & $\begin{array}{l}\text { Brasília } \\
\text { (DF) }\end{array}$ & Intermediária & 16,5 & 157 & $\begin{array}{l}\text { Fernandes } \\
(2004)\end{array}$ \\
\hline
\end{tabular}

\footnotetext{
(y) Vermelho

(z) Branco

(aa) Misto

(bb) não especificado(a)

(cc) Valor aproximado
}

Comparando-se os valores da Tabela 5.10 com aqueles encontrados na presente pesquisa (em números médios), tem-se que o ISC do agregado reciclado estudado aos zero dias de cura de $75 \%$, apresentou-se de forma intermediária aos resultados obtidos por Bodi et al. (1995) para materiais vermelhos e mistos também de São Paulo, com valores de $63 \%$ e $98 \%$, respectivamente (embora não tenha sido definida a energia de compactação destes). Além disso, aos 90 dias de cura, o agregado reciclado estudado assumiu característica de suporte em torno de $115 \%$, cujo valor é semelhante à do material constituído por agregados de concreto daqueles mesmos pesquisadores.

Assim como na Tabela 5.9, verifica-se na Tabela 5.10 uma significativa diferença entre os valores de ISC obtidos para os diferentes agregados reciclados que, da 
mesma forma, pode ter ocorrido devido a fatores como composição ou tipo de material, graduação, energia de compactação utilizada ou teor de umidade empregado.

\subsubsection{Resistência à Tração por Compressão Diametral}

O ensaio para determinação da Resistência à Tração por Compressão Diametral (RTCD) tem por objetivo determinar a máxima tensão a que pode ser submetido o corpo-de-prova, no sentido diametral, até que o mesmo seja rompido por tração. Em termos reais, isto simula o que pode ocorrer numa estrutura de pavimento quando uma determinada carga é aplicada e a parte inferior da camada passa a ser tracionada por flexão, devendo resistir com coesão ou cimentação e não simplesmente por compressão.

O experimento foi realizado tomando-se como base alguns princípios descritos na especificação NBR 15087 (2004) para misturas asfálticas, uma vez que não existem normas relacionadas ao assunto para agregados reciclados.

O valor da Resistência à Tração por Compressão Diametral é definido como a relação entre a carga aplicada e as características geométricas do corpo-de-prova, podendo ser calculado através da expressão (3):

$R T C D=\frac{2 \cdot F}{\pi \cdot D \cdot H}$

onde:

RTCD é a Resistência à Tração por Compressão Diametral, em [MPa];

F é a carga de ruptura, em [N];

D é o diâmetro do corpo-de-prova, em [mm];

Hé a altura do corpo-de-prova, em [mm].

A Figura 5.54 ilustra a ruptura ocorrida em um corpo-de-prova após a aplicação de carga no ensaio de Resistência à Tração por Compressão Diametral. 


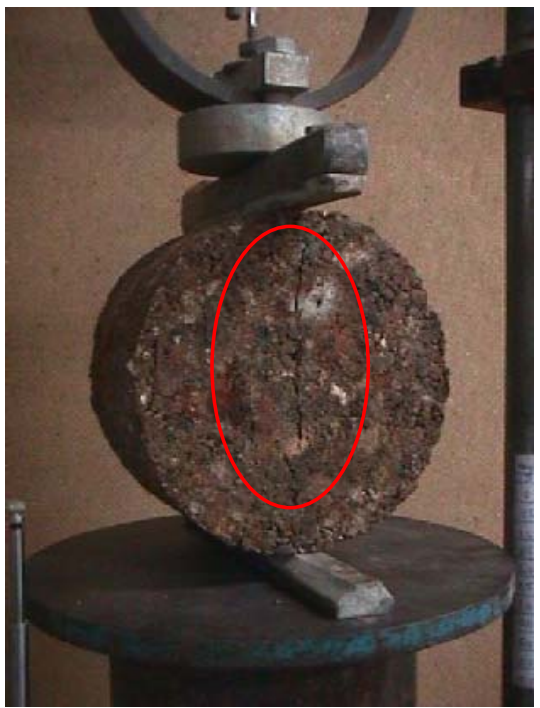

Figura 5.54: Corpo-de-prova rompido no ensaio de Resistência à Tração por Compressão Diametral

Em virtude de problemas ocorridos durante a fase de ensaios, 3 dos 39 corpos-deprova moldados para a análise de Resistência à Tração por Compressão Diametral não foram contabilizados nos resultados finais ( 1 com $4 \%$ de cal e 2 com $4 \%$ de cimento Portland, sendo todos eles para os experimentos aos 28 dias de cura).

Os valores obtidos nos ensaios de Resistência à Tração por Compressão Diametral são apresentados na Figura 5.55 e na Tabela 5.11. Na Figura 5.55, os pontos representam os valores de RTCD alcançados e as curvas demonstram suas linhas de tendência, conforme o tipo de material analisado. 


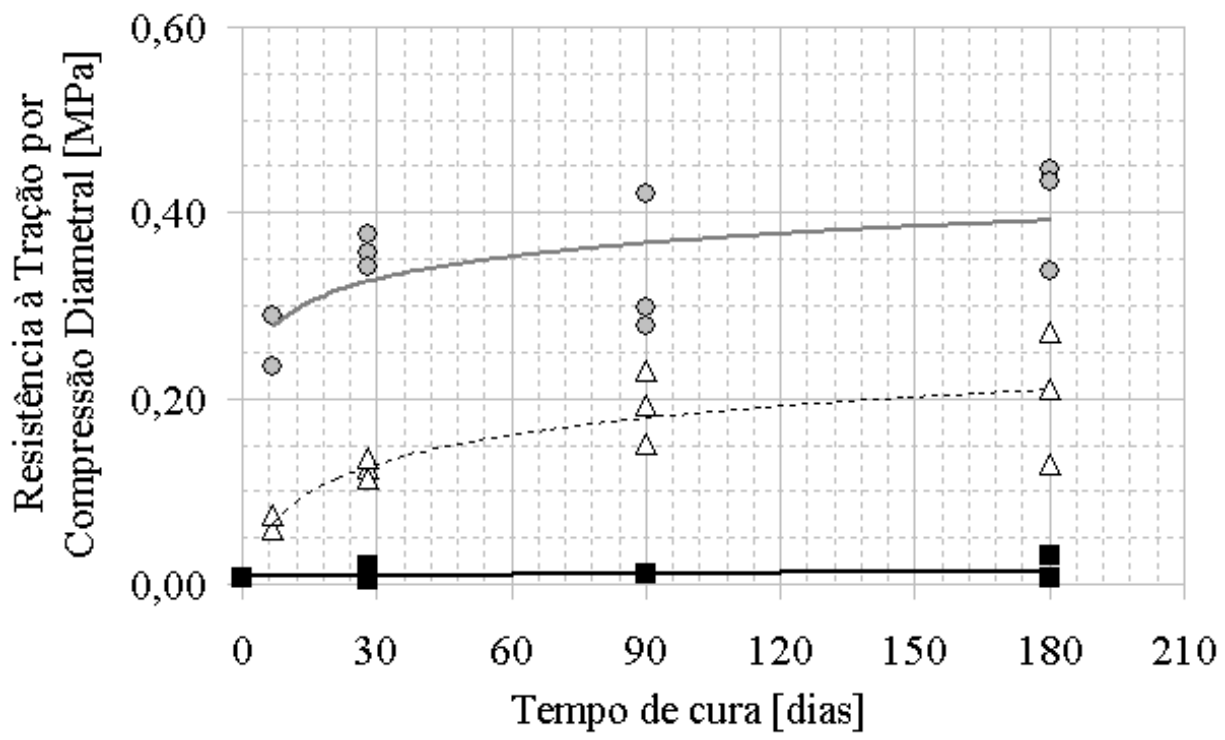

in natura

$\triangle$ cal

cimento Portland

linha de tendência - in natura . . - linha de tendência - cal

linha de tendência - cimento Portland

Figura 5.55: Resultado dos ensaios de Resistência à Tração por Compressão Diametral 
Tabela 5.11: Resultado dos ensaios de Resistência à Tração por Compressão Diametral

\begin{tabular}{|c|c|c|}
\hline $\begin{array}{c}\text { Tipo de } \\
\text { corpo-de-prova }\end{array}$ & $\begin{array}{c}\text { Tempo } \\
\text { de cura } \\
\text { [dias] }\end{array}$ & $\begin{array}{c}\text { Resistência à Tração por } \\
\text { Compressão Diametral } \\
\text { [MPa] }\end{array}$ \\
\hline \multirow{13}{*}{ in natura } & 0 & 0,01 \\
\hline & 0 & 0,01 \\
\hline & 28 & 0,01 \\
\hline & 28 & 0,01 \\
\hline & 28 & 0,01 \\
\hline & 28 & 0,02 \\
\hline & 28 & 0,01 \\
\hline & 90 & 0,01 \\
\hline & 90 & 0,01 \\
\hline & 90 & 0,01 \\
\hline & 180 & 0,01 \\
\hline & 180 & 0,01 \\
\hline & 180 & 0,03 \\
\hline \multirow{12}{*}{ com $4 \%$ de cal } & 7 & 0,06 \\
\hline & 7 & 0,08 \\
\hline & 28 & 0,12 \\
\hline & 28 & 0,13 \\
\hline & 28 & 0,12 \\
\hline & 28 & 0,14 \\
\hline & 90 & 0,19 \\
\hline & 90 & 0,23 \\
\hline & 90 & 0,15 \\
\hline & 180 & 0,21 \\
\hline & 180 & 0,13 \\
\hline & 180 & 0,27 \\
\hline \multirow{11}{*}{$\begin{array}{c}\text { com } 4 \% \text { de } \\
\text { cimento Portland }\end{array}$} & 7 & 0,29 \\
\hline & 7 & 0,23 \\
\hline & 28 & 0,36 \\
\hline & 28 & 0,38 \\
\hline & 28 & 0,34 \\
\hline & 90 & 0,28 \\
\hline & 90 & 0,30 \\
\hline & 90 & 0,42 \\
\hline & 180 & 0,34 \\
\hline & 180 & 0,45 \\
\hline & 180 & 0,43 \\
\hline
\end{tabular}

Os dados apresentados na Figura 5.55 (ou na Tabela 5.11) mostram uma certa dispersão entre resultados de corpos-de-prova submetidos ao mesmo tempo de cura, 
possivelmente devido à heterogeneidade do material. Embora isto ocorra, a hierarquização da resistência em função de cada tipo de material (in natura, com cal ou cimento Portland) é a mesma daquela obtida pelo ensaio de Resistência à Compressão Simples, como será visto no item seguinte.

Observa-se que a Resistência à Tração por Compressão Diametral do material in natura praticamente não se alterou em todos as fases de cura, ficando este valor em torno de $0,01 \mathrm{MPa}$.

Com a incorporação de 4\% de cal ou 4\% de cimento Portland, a Resistência à Tração por Compressão Diametral se elevou expressivamente, em relação ao material in natura. Tomando-se valores médios de RTCD após um mesmo tempo de cura, temse que o agregado reciclado com $4 \%$ de cal apresentou ganho de resistência de aproximadamente 13, 18 e 10 vezes aos 28, 90 e 180 dias, respectivamente, em comparação com o material in natura. Já o que continha $4 \%$ de cimento Portland passou a ser cerca de 33, 37 e 20 vezes maior aos 28,90 e 180 dias, respectivamente, que o in natura.

Já que a norma que foi utilizada neste ensaio é direcionada para misturas asfálticas, cabe mencionar que a Resistência à Tração por Compressão Diametral de corpos-deprova de agregados reciclados com $4 \%$ de cimento Portland chegaram a atingir quase metade da RTCD usual de misturas asfálticas (que é um material muito mais coeso), ou cerca de $0,45 \mathrm{MPa}$ e $1 \mathrm{MPa}$, respectivamente.

\subsubsection{Resistência à Compressão Simples}

O ensaio para determinação da Resistência à Compressão Simples (RCS) tem por objetivo determinar a máxima tensão a que pode ser submetido o corpo-de-prova, no sentido axial, até que o mesmo seja rompido pela compressão. No meio rodoviário, normalmente este experimento é utilizado para analisar misturas cimentadas, como solo-cimento ou BGTC (brita graduada tratada com cimento). 
O ensaio foi realizado tomando-se como base alguns princípios descritos na especificação DNER-ME 201/94 (1994) para solo-cimento.

O valor da Resistência à Compressão Simples é definido como a relação entre a carga aplicada, no sentido axial, e a área da seção transversal do corpo-de-prova, podendo ser calculado através da expressão (4):

$R C S=\frac{F}{A}$

onde:

RCS é a Resistência à Compressão Simples, em [MPa];

F é a força aplicada axialmente, em [N];

A é a área da seção do corpo-de-prova, em [ $\left.\mathrm{mm}^{2}\right]$.

A Figura 5.56 ilustra o corpo-de-prova posicionado na prensa para aplicação da carga axial, até o seu rompimento.

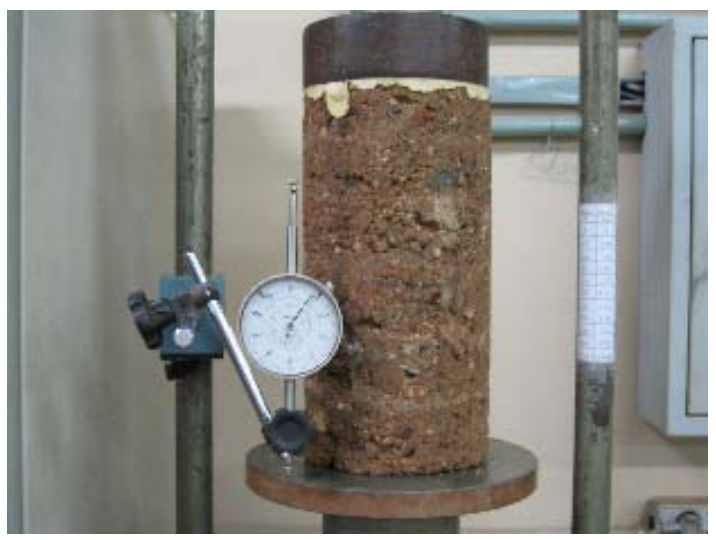

Figura 5.56: Corpo-de-prova no ensaio de Resistência à Compressão Simples

Neste experimento foram utilizados os mesmos corpos-de-prova já submetidos ao ensaio de Módulo de Resiliência (por este ser um experimento não-destrutivo), além de outros moldados somente para esta fase para a obtenção da Resistência à Compressão Simples também aos 7 dias de cura das misturas de agregado reciclado com $4 \%$ de cal e com $4 \%$ de cimento Portland. 
Em virtude de problemas ocorridos durante a fase de ensaios, 2 dos 33 corpos-deprova moldados para a análise de Resistência à Compressão Simples (um com 4\% de cal e outro com 4\% de cimento Portland, para experimentos aos 180 e 90 dias de cura, respectivamente) não foram contabilizados nos resultados finais.

Os valores obtidos nos ensaios de Resistência à Compressão Simples são apresentados na Figura 5.57 e na Tabela 5.12. Na Figura 5.57, os pontos representam os valores de RCS alcançados e as curvas demonstram suas linhas de tendência, conforme o tipo de material analisado.

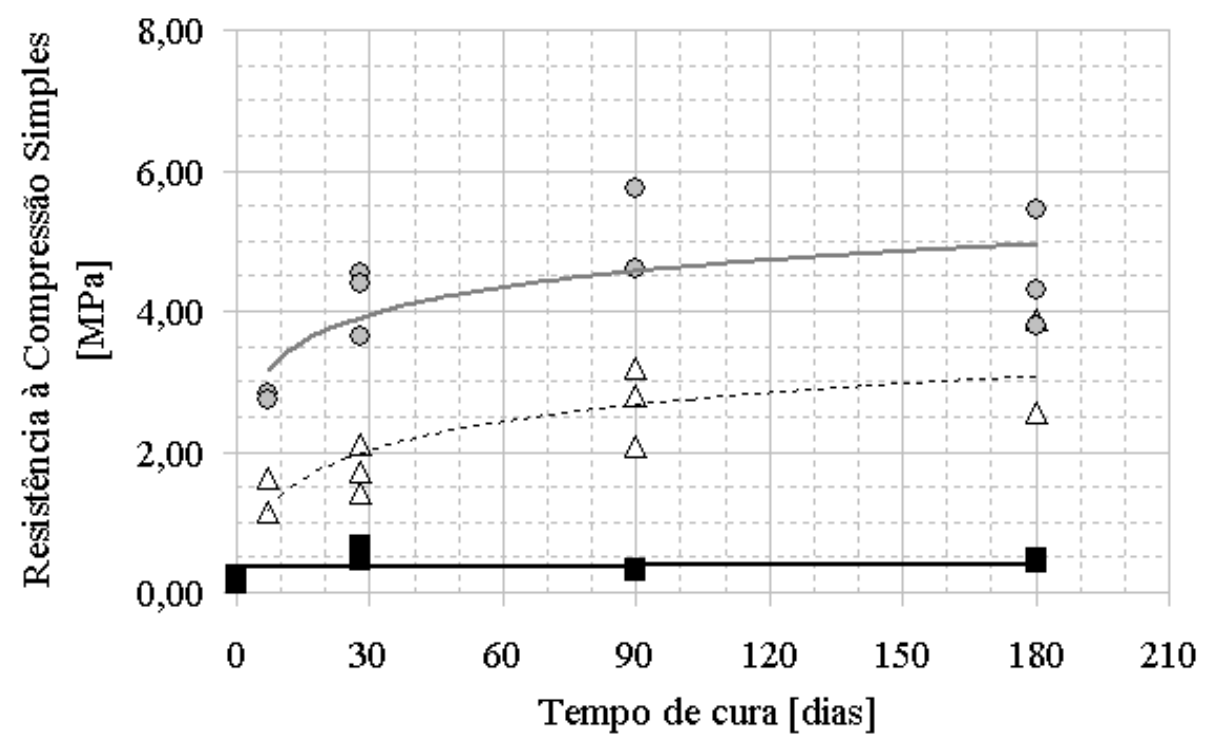
in natura
$\triangle \mathrm{cal}$
O cimento Portland
linha de tendência - in natura _. - linha de tendência - cal linha de tendência - cimento Portland

Figura 5.57: Resultado dos ensaios de Resistência à Compressão Simples 
Tabela 5.12: Resultado dos ensaios de Resistência à Compressão Simples

\begin{tabular}{|c|c|c|}
\hline $\begin{array}{c}\text { Tipo de } \\
\text { corpo-de-prova }\end{array}$ & $\begin{array}{c}\text { Tempo } \\
\text { de cura } \\
\text { [dias] }\end{array}$ & $\begin{array}{c}\text { Resistência à } \\
\text { Compressão Simples } \\
\text { [MPa] }\end{array}$ \\
\hline \multirow{11}{*}{ in natura } & 0 & 0,13 \\
\hline & 0 & 0,25 \\
\hline & 28 & 0,46 \\
\hline & 28 & 0,66 \\
\hline & 28 & 0,48 \\
\hline & 90 & 0,31 \\
\hline & 90 & 0,35 \\
\hline & 90 & 0,34 \\
\hline & 180 & 0,41 \\
\hline & 180 & 0,43 \\
\hline & 180 & 0,48 \\
\hline \multirow{10}{*}{ com $4 \%$ de cal } & 7 & 1,62 \\
\hline & 7 & 1,13 \\
\hline & 28 & 1,41 \\
\hline & 28 & 1,71 \\
\hline & 28 & 2,10 \\
\hline & 90 & 2,78 \\
\hline & 90 & 2,09 \\
\hline & 90 & 3,19 \\
\hline & 180 & 3,88 \\
\hline & 180 & 2,56 \\
\hline \multirow{10}{*}{$\begin{array}{l}\text { com } 4 \% \text { de } \\
\text { cimento Portland }\end{array}$} & 7 & 2,84 \\
\hline & 7 & 2,73 \\
\hline & 28 & 3,64 \\
\hline & 28 & 4,56 \\
\hline & 28 & 4,39 \\
\hline & 90 & 5,73 \\
\hline & 90 & 4,60 \\
\hline & 180 & 5,44 \\
\hline & 180 & 3,80 \\
\hline & 180 & 4,31 \\
\hline
\end{tabular}

Da mesma maneira que no ensaio de Resistência à Tração por Compressão Diametral, os resultados de Resistência à Compressão Simples demonstraram alguma dispersão, como apontam a Figura 5.57 e a Tabela 5.12. Nota-se que os números referentes ao material in natura também mantiveram-se aproximadamente constantes ao longo dos diferentes tempos de cura, porém com valor de cerca de $0,40 \mathrm{MPa}$ (conforme linha de tendência da Figura 5.57). 
Com a adição de $4 \%$ de cal ou $4 \%$ de cimento Portland, a Resistência à Compressão Simples do agregado reciclado se elevou significativamente, em relação ao material in natura. Tomando-se valores médios de RCS após um mesmo tempo de cura, temse que o agregado reciclado com $4 \%$ de cal apresentou ganho de resistência de aproximadamente 3, 8 e 7 vezes aos 28, 90 e 180 dias, respectivamente, em comparação com o material in natura. Já o que continha 4\% de cimento Portland passou a ser cerca de 8,16 e 10 vezes maior aos 28,90 e 180 dias, respectivamente, que o in natura.

Hill et al. (2001) mencionam que quando a qualidade mecânica de um agregado é menor que a de materiais convencionalmente empregados, a estabilização pode ser uma opção para um melhor desempenho.

A especificação NBR 15115 (2004) prevê a estabilização granulométrica do agregado reciclado através da adição de cal e/ou cimento Portland, como forma de promover uma maior resistência, devendo atingir 2,1MPa no mínimo após 7 dias de cura. $\mathrm{Na}$ presente pesquisa, as misturas com $4 \%$ de cimento Portland atingiram valores superiores ao que é preconizado pela referida norma, chegando a $2,78 \mathrm{MPa}$ em média aos 7 dias de cura. Por outro lado, as misturas com 4\% de cal apresentaram valores inferiores ao mínimo especificado, ou 1,38MPa em média aos 7 dias de cura, e só atingiram os $2,1 \mathrm{MPa}$ requeridos pela norma aproximadamente aos 90 dias de cura.

A título de comparação, em se tratando de Resistência à Compressão Simples do solo-cimento e da BGTC, a NBR 11798 (1990) especifica que o valor médio a ser atingido após 7 dias no caso do solo-cimento deve estar compreendido entre $3,5 \mathrm{MPa}$ e 8,0MPa, e da BGTC, a NBR 11803 (1991) determina que o valor mínimo, também aos 7 dias, deve ser de 2,1MPa.

\subsubsection{Módulo de Resiliência}

Segundo Medina (1997), o termo resiliência pode ser definido como "energia armazenada num corpo deformado elasticamente, a qual é devolvida quando cessam 
as tensões causadoras das deformações" e "corresponde à energia potencial de deformação" (p.158).

Em pavimentação, o termo deformação resiliente significa deformação recuperável da estrutura do pavimento quando este é submetido a carregamentos repetidos. Bernucci (1995) e Medina (1997) mencionam que o pesquisador Francis Hveem propôs o termo deformação resiliente, ao invés de deformação elástica, pelo fato de as deformações serem muito maiores nos pavimentos que em sólidos elásticos como ferro, concreto, vidro, etc.

Hveem desenvolveu o primeiro equipamento para medir o efeito da aplicação de cargas repetidas nos materiais, chamado de resiliômetro, no ano de 1946. Em seguida, na década de 50, Seed e Fead desenvolveram um equipamento triaxial dinâmico, no qual os modelos atuais são baseados (BERNUCCI, 1995).

De acordo com Bennert et al. (2000), os engenheiros rodoviários têm reconhecido ultimamente que ensaios triaxiais de carga cíclica são mecanismos fundamentais para avaliar materiais a serem utilizados nas camadas inferiores de um pavimento.

A Figura 5.58 ilustra o equipamento triaxial de carga repetida de curta duração do LTP-EPUSP em que ocorrem os ensaios de Módulo de Resiliência. Neste experimento, são aplicadas tensões de confinamento e tensões axiais de modo a simular as condições de campo a que o material fica submetido (BENNERT et al., 2000; HILL et al., 2001). 


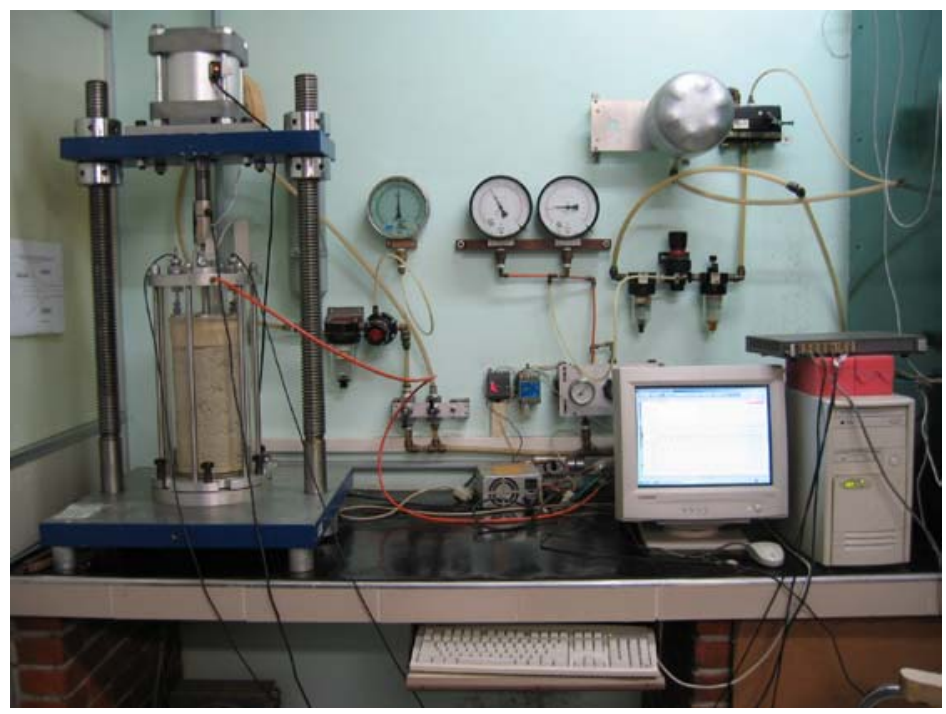

Figura 5.58: Equipamento triaxial de carga repetida e sistema de aquisição de dados para obtenção do Módulo de Resiliência no LTP-EPUSP

O valor de Módulo de Resiliência é definido como a relação entre a tensão desvio, denominada $\sigma_{\mathrm{d}}$, e a correspondente deformação específica axial resiliente ou recuperável, denominada $\varepsilon_{\mathrm{r}}$, sendo calculado através da expressão (5). A tensão desvio $\left(\sigma_{\mathrm{d}}\right)$ equivale à tensão de confinamento $\left(\sigma_{3}\right)$ subtraída da tensão axial $\left(\sigma_{1}\right)$, aplicadas no corpo-de-prova.

$M R=\frac{\sigma_{d}}{\varepsilon_{r}}$

onde:

MR é o Módulo de Resiliência, em [MPa];

$\sigma_{d}$ é a tensão desvio aplicada, em [MPa];

$\varepsilon_{r}$ é a deformação específica axial resiliente, em [mm/mm].

Bernucci (1995) cita que a natureza e o estado dos materiais, além da solicitação de carga são variáveis intervenientes no valor do módulo resiliente.

Nesta pesquisa, o experimento foi realizado de forma semelhante ao especificado na norma do DNER-ME 131/94 (1994) para solos. 
Em virtude de problemas ocorridos durante a fase de ensaios, 4 dos 29 corpos-deprova moldados para a análise de Módulo de Resiliência não foram contabilizados nos resultados finais ( 3 com 4\% de cal - para experimentos aos 28, 90 e 180 dias de cura - e 1 com 4\% de cimento Portland - para 90 dias de cura).

As tensões de condicionamento a que os corpos-de-prova foram submetidos nos ensaios de Módulo de Resiliência são apresentadas na Tabela 5.13. Segundo Medina (1997), “esse condicionamento prévio (...) reduz a influência das deformações permanentes" (p.163).

Tabela 5.13: Tensões aplicadas para condicionamento do corpo-de-prova no ensaio de Módulo de Resiliência

\begin{tabular}{|c|c|c|}
\hline $\begin{array}{c}\text { Etapas de } \\
\text { condicionamento }\end{array}$ & $\begin{array}{c}\boldsymbol{\sigma}_{\mathbf{3}} \\
{[\mathbf{M P a}]}\end{array}$ & $\begin{array}{c}\sigma_{\mathbf{d}} \\
{[\mathbf{M P a}]}\end{array}$ \\
\hline 1 & 0,070 & 0,070 \\
\hline 2 & 0,105 & 0,200 \\
\hline 3 & 0,150 & 0,315 \\
\hline
\end{tabular}

Já na Tabela 5.14 é possível observar as tensões de carregamento para obtenção das deformações elásticas. 
Tabela 5.14: Tensões de carregamento aplicadas na etapa de registro no sistema de aquisição de dados no ensaio de Módulo de Resiliência

\begin{tabular}{|c|c|c|}
\hline $\begin{array}{c}\text { Etapas de } \\
\text { carregamento }\end{array}$ & $\begin{array}{c}\sigma_{3} \\
{[\mathrm{MPa}]}\end{array}$ & $\begin{array}{c}\sigma_{\mathrm{d}} \\
{[\mathrm{MPa}]}\end{array}$ \\
\hline 1 & \multirow{4}{*}{0,021} & 0,070 \\
\hline 2 & & 0,100 \\
\hline 3 & & 0,150 \\
\hline 4 & & 0,200 \\
\hline 5 & \multirow{4}{*}{0,050} & 0,070 \\
\hline 6 & & 0,100 \\
\hline 7 & & 0,150 \\
\hline 8 & & 0,200 \\
\hline 9 & \multirow{4}{*}{0,070} & 0,070 \\
\hline 10 & & 0,100 \\
\hline 11 & & 0,150 \\
\hline 12 & & 0,200 \\
\hline 13 & \multirow{4}{*}{0,100} & 0,070 \\
\hline 14 & & 0,100 \\
\hline 15 & & 0,150 \\
\hline 16 & & 0,200 \\
\hline 17 & \multirow{4}{*}{0,150} & 0,070 \\
\hline 18 & & 0,100 \\
\hline 19 & & 0,150 \\
\hline 20 & & 0,200 \\
\hline
\end{tabular}

A partir dos deslocamentos resilientes coletados no ensaio e da expressão (5) é possível determinar os valores de Módulo de Resiliência para cada par de tensões $\sigma_{3}$ e $\sigma_{\mathrm{d}}$ que foi imposto ao corpo-de-prova, e apresentá-los graficamente (tem-se como exemplo a Figura 5.59, que mostra o resultado do ensaio de $u m$ corpo-de-prova com 4\% de cimento Portland aos 90 dias de cura). No gráfico, os pontos demonstram os valores obtidos no experimento para cada $\sigma_{\mathrm{d}}$ e a expressão apresenta o Módulo de Resiliência em função de $\sigma_{3}$ e $\sigma_{d}$ de acordo com o modelo proposto por Macêdo $(1996)^{(27)}$ apud Fernandes (2004). Este último autor cita que o modelo, que está indicado na expressão (6), apresentou boa correlação tanto para solos argilosos quanto para granulares, alcançando valores acima de 0,90 .

(27) Macêdo, J. A. G. Interpretação de ensaios deflectométricos para avaliação estrutural de pavimentos flexíveis- A experiência com FWD no Brasil. 1996. Tese (Doutorado) - Coordenação dos Programas de Pós-Graduação de Engenharia da Universidade Federal do Rio de Janeiro (COPPEUFRJ). Rio de Janeiro, 1996. 
$M R=k_{1} \cdot \sigma_{3}^{k_{2}} \cdot \sigma_{d}{ }^{k_{3}}$

onde:

MR é o Módulo de Resiliência;

$\kappa_{1}, \kappa_{2}$ e $\kappa_{3}$ são constantes ou parâmetros experimentais;

$\sigma_{3}$ é a tensão de confinamento;

$\sigma_{d}$ é a tensão desvio.

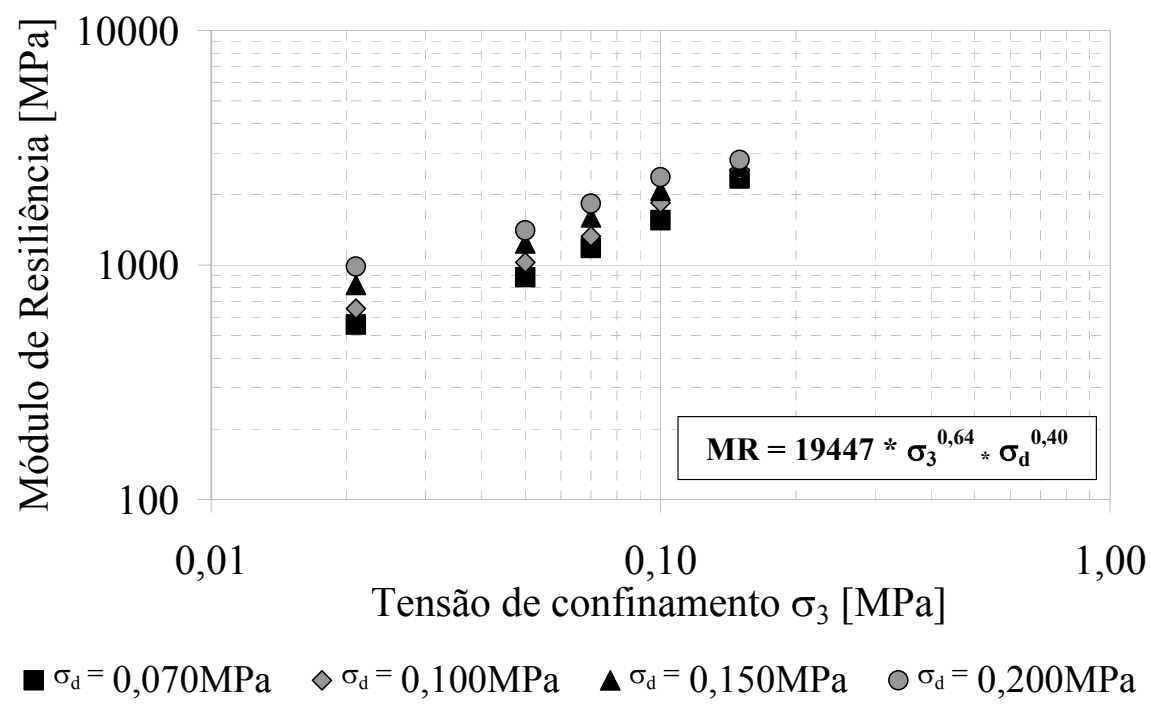

Figura 5.59: Módulo de Resiliência de corpo-de-prova com 4\% de cimento Portland aos 90 dias de cura

Os gráficos obtidos nos ensaios de todos os corpos-de-prova desta pesquisa são apresentados no Anexo B, conforme tipo de material analisado e tempo de cura.

Para comparar e analisar os resultados obtidos, procurou-se inicialmente identificar qual o par de tensões $\sigma_{3}$ e $\sigma_{\mathrm{d}}$ que estaria atuando no centro de uma camada de base e de sub-base de um pavimento de baixo volume de tráfego. Isto foi feito por meio do programa computacional ELSYM5, no qual simulou-se um pavimento com as seguintes características:

- revestimento asfáltico de $2 \mathrm{~cm}$ de espessura, com coeficiente de Poisson de 0,30 e Módulo de Resiliência de 2.000MPa; 
- base de $15 \mathrm{~cm}$ de espessura, com coeficiente de Poisson de 0,35 e Módulo de Resiliência de 400MPa;

- sub-base de $15 \mathrm{~cm}$ de espessura, com coeficiente de Poisson de 0,35 e Módulo de Resiliência de 200MPa;

- subleito com coeficiente de Poisson de 0,40 e Módulo de Resiliência de $100 \mathrm{MPa}$;

- duas cargas aplicadas de $2500 \mathrm{kgf}$; e pressão de contato de $0,56 \mathrm{kgf} / \mathrm{cm}^{2}$.

O programa ELSYM5 mostrou que no centro da camada de base deste pavimento, a uma profundidade de cerca de $9,5 \mathrm{~cm}$, o par de tensões $\sigma_{3}$ e $\sigma_{\mathrm{d}}$ que atuam são 0,227MPa e 0,221MPa, respectivamente. Já no centro da camada de sub-base, em uma profundidade em torno de $24,5 \mathrm{~cm}$, as tensões $\sigma_{3}$ e $\sigma_{\mathrm{d}}$ são menores, e passam a ser $0,125 \mathrm{MPa}$ e $0,163 \mathrm{MPa}$, respectivamente. Os valores devem ser considerados aproximados; para o cálculo mais preciso das tensões atuantes é aconselhável utilizar Método dos Elementos Finitos uma vez que se trata de elasticidade não-linear. Além disso, o programa ELSYM5 não leva em consideração a tensão atuante devida ao peso próprio.

Com isto, as comparações dos resultados obtidos nos ensaios se darão nos pontos ilustrados nos gráficos a seguir (Figura 5.60 à Figura 5.71) onde $\sigma_{3}$ e $\sigma_{d}$ são respectivamente $0,227 \mathrm{MPa}$ e $0,200 \mathrm{MPa}$ por ocorrerem na base do pavimento simulado, e $0,125 \mathrm{MPa}$ e $0,150 \mathrm{MPa}$, por incidirem na sub-base do mesmo.

Da Figura 5.60 à Figura 5.65, os resultados de Módulo de Resiliência estão agrupados conforme o tipo de material estudado (in natura, com 4\% de cal e com 4\% de cimento Portland), para $\sigma_{\mathrm{d}}$ de $0,200 \mathrm{MPa}$ e também de $0,150 \mathrm{MPa}$. 


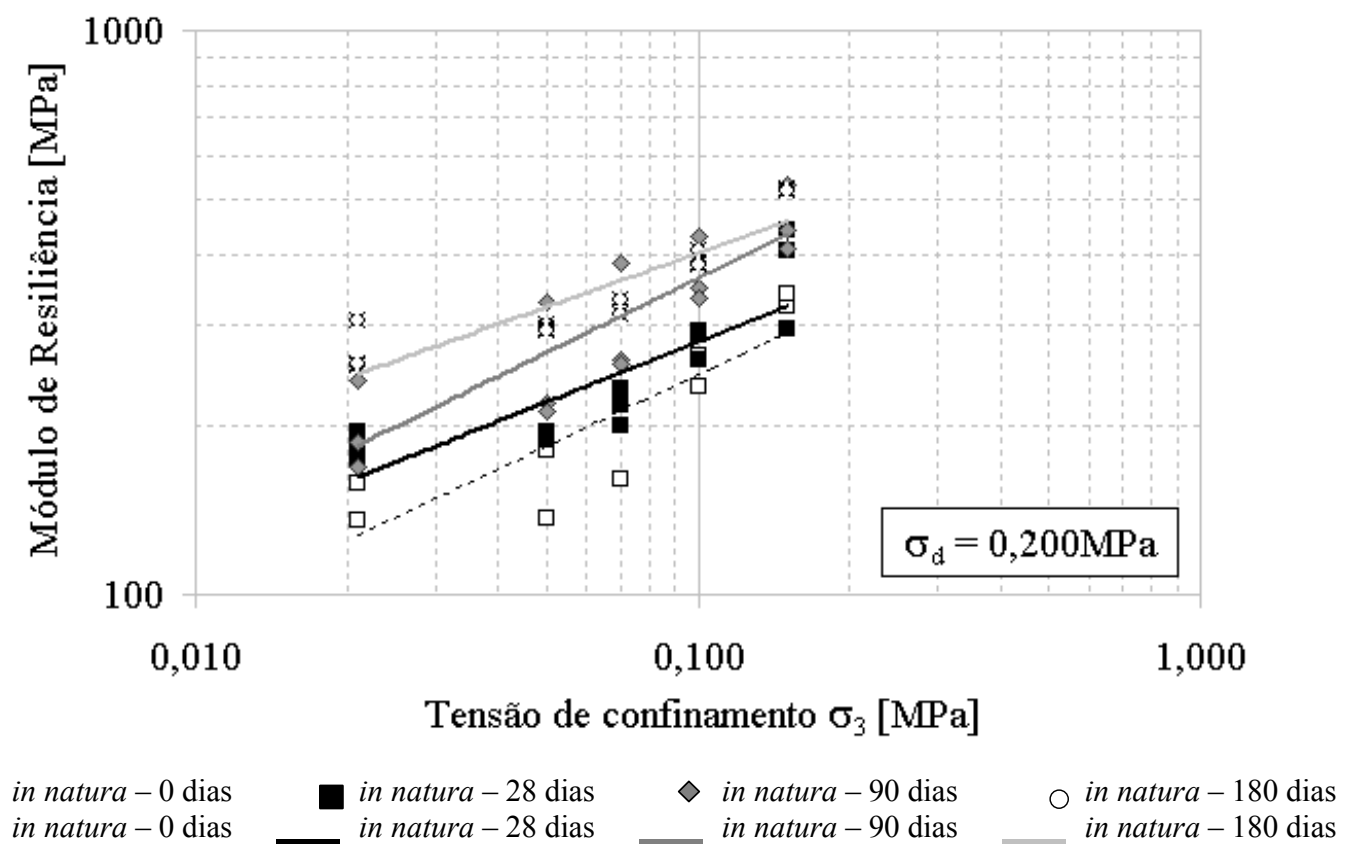

Figura 5.60: Evolução do Módulo de Resiliência com o tempo de cura em corpos-deprova in natura, para $\sigma_{\mathrm{d}}$ de $0,200 \mathrm{MPa}$

$\mathrm{Na}$ Figura 5.60 observa-se que os corpos-de-prova do tipo in natura sofreram aumento do Módulo de Resiliência com o tempo, embora haja uma certa dispersão dos resultados, principalmente aos zero dias de cura; para $\sigma_{3}$ de $0,227 \mathrm{MPa}$ e $\sigma_{\mathrm{d}}$ de 0,200MPa (tensões na base do pavimento estudado), tem-se que o Módulo de Resiliência, ao se extrapolar as linhas de tendência, cresce cerca de $8 \%$ dos 0 aos 28 dias, e mais 39\% dos 28 aos 90 dias de cura. Após este período, não se verificou aumento do Módulo de Resiliência. De maneira geral, o crescimento do Módulo de Resiliência acumulado após 180 dias de cura foi de $51 \%$.

Já no caso de $\sigma_{3}$ igual a $0,125 \mathrm{MPa}$ e $\sigma_{\mathrm{d}}$ de $0,150 \mathrm{MPa}$ (tensões na sub-base do pavimento analisado), registrou-se um aumento do Módulo de Resiliência do material in natura em torno de $66 \%$ dos 0 aos 28 dias, de $25 \%$ dos 28 aos 90 dias, e de $8 \%$ dos 90 aos 180 dias de cura. No geral, a Figura 5.61 aponta que o Módulo de Resiliência cresceu aproximadamente $24 \%$ dos 0 aos 180 dias (de maneira acumulada). 


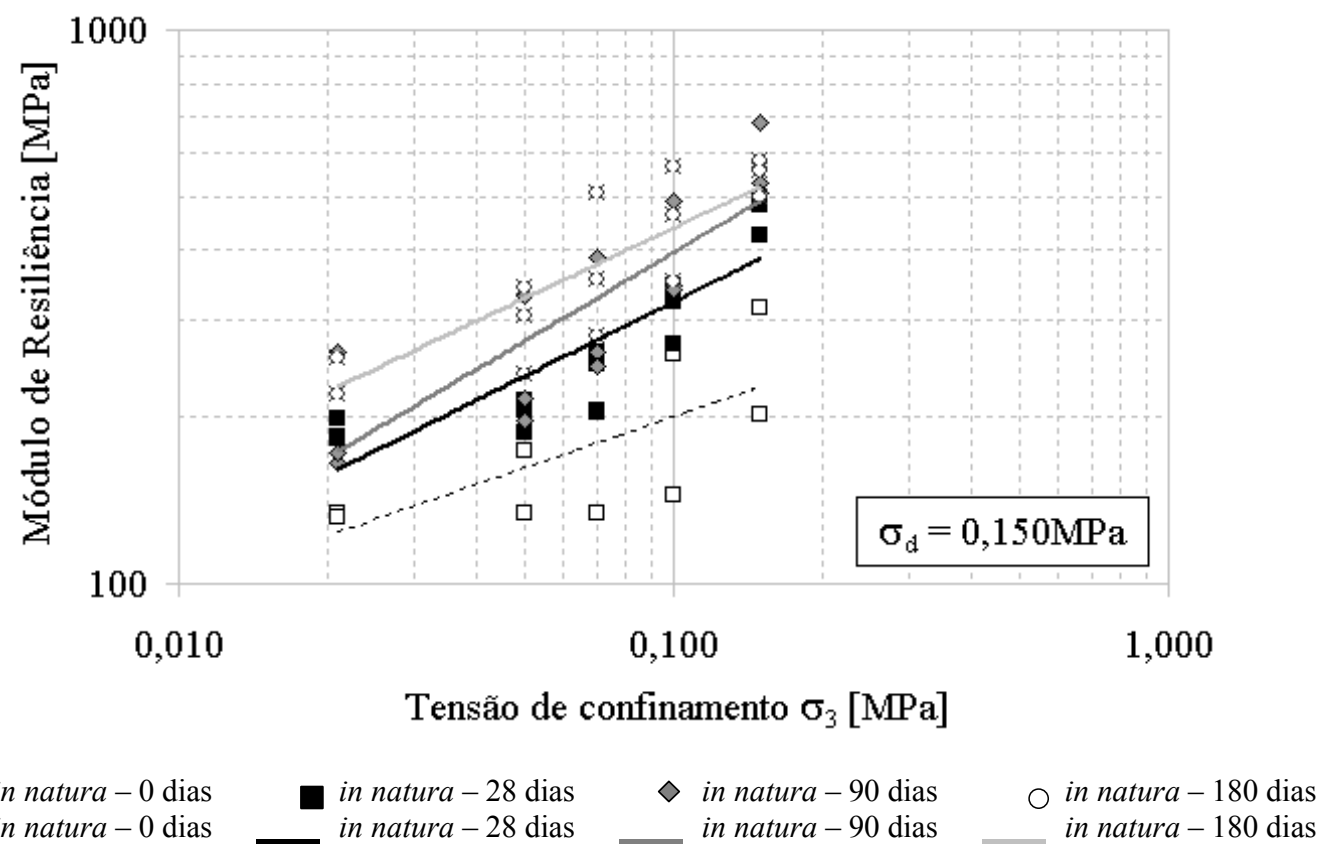

Figura 5.61: Evolução do Módulo de Resiliência com o tempo de cura em corpos-deprova in natura, para $\sigma_{\mathrm{d}}$ de $0,150 \mathrm{MPa}$

Como estes resultados tratam do agregado reciclado sem a adição de aglomerantes, então há indícios de que houve reação pozolânica por parte de partículas que ainda possuíam potencial reativo, observado principalmente nas primeiras idades, o que mostra que o agregado reciclado estudado não era totalmente inerte. 


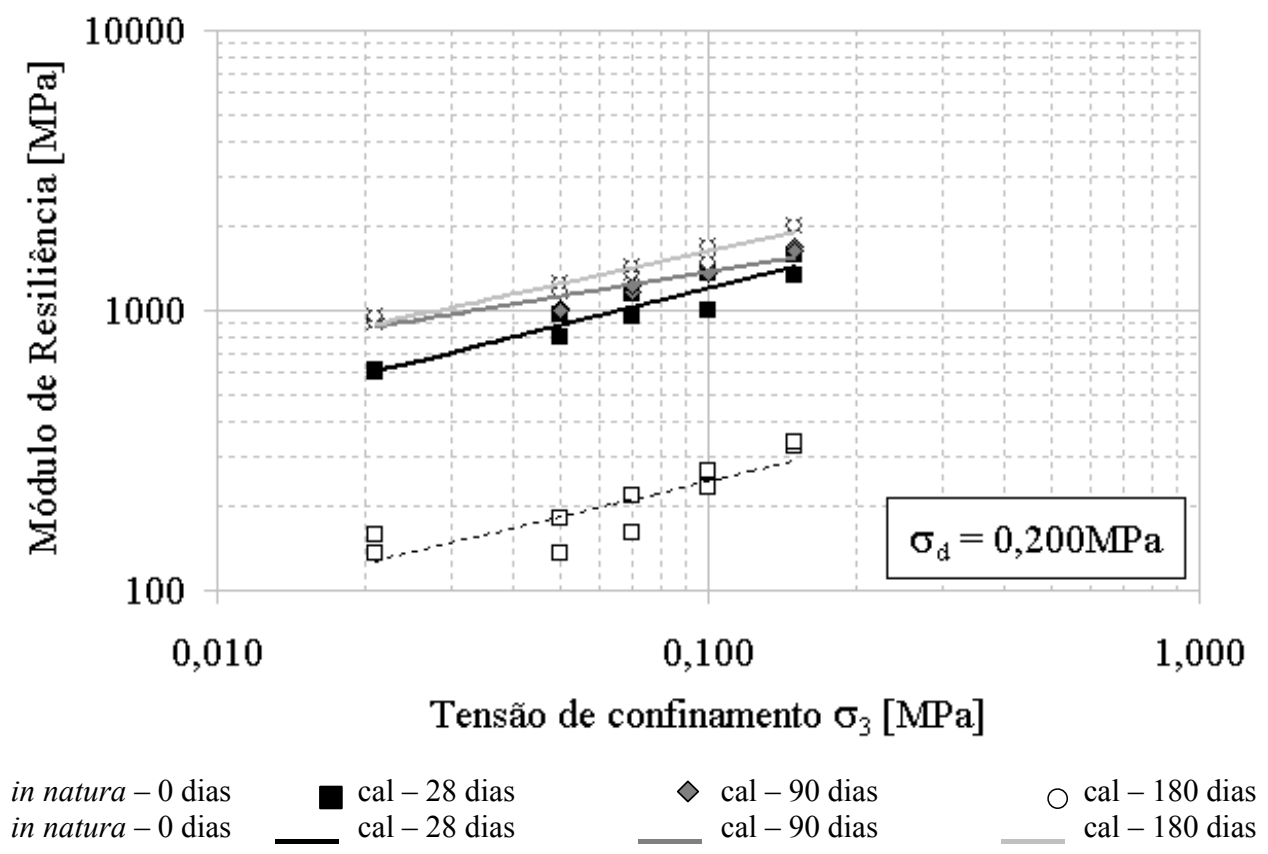

Figura 5.62: Evolução do Módulo de Resiliência com o tempo de cura em corpos-deprova com $4 \%$ de cal, para $\sigma_{\mathrm{d}}$ de $0,200 \mathrm{MPa}$

Na Figura 5.62, nota-se que, para $\sigma_{3}$ de $0,227 \mathrm{MPa}$ e $\sigma_{\mathrm{d}}$ igual a $0,200 \mathrm{MPa}$ (tensões na base do pavimento estudado), tem-se que o Módulo de Resiliência, ao se extrapolar as linhas de tendência, praticamente não sofre alteração dos 28 aos 90 dias de cura. A partir daí, entre 90 e 180 dias, o mesmo passa a ser cerca de $28 \%$ maior.

Já para $\sigma_{3}$ igual a $0,125 \mathrm{MPa}$ e $\sigma_{\mathrm{d}}$ de $0,150 \mathrm{MPa}$ (tensões na sub-base do pavimento analisado), é possível observar na Figura 5.63 que houve aumento do Módulo de Resiliência em torno de $14 \%$ dos 28 aos 90 dias, e de mais $27 \%$ dos 90 aos 180 dias de cura. 


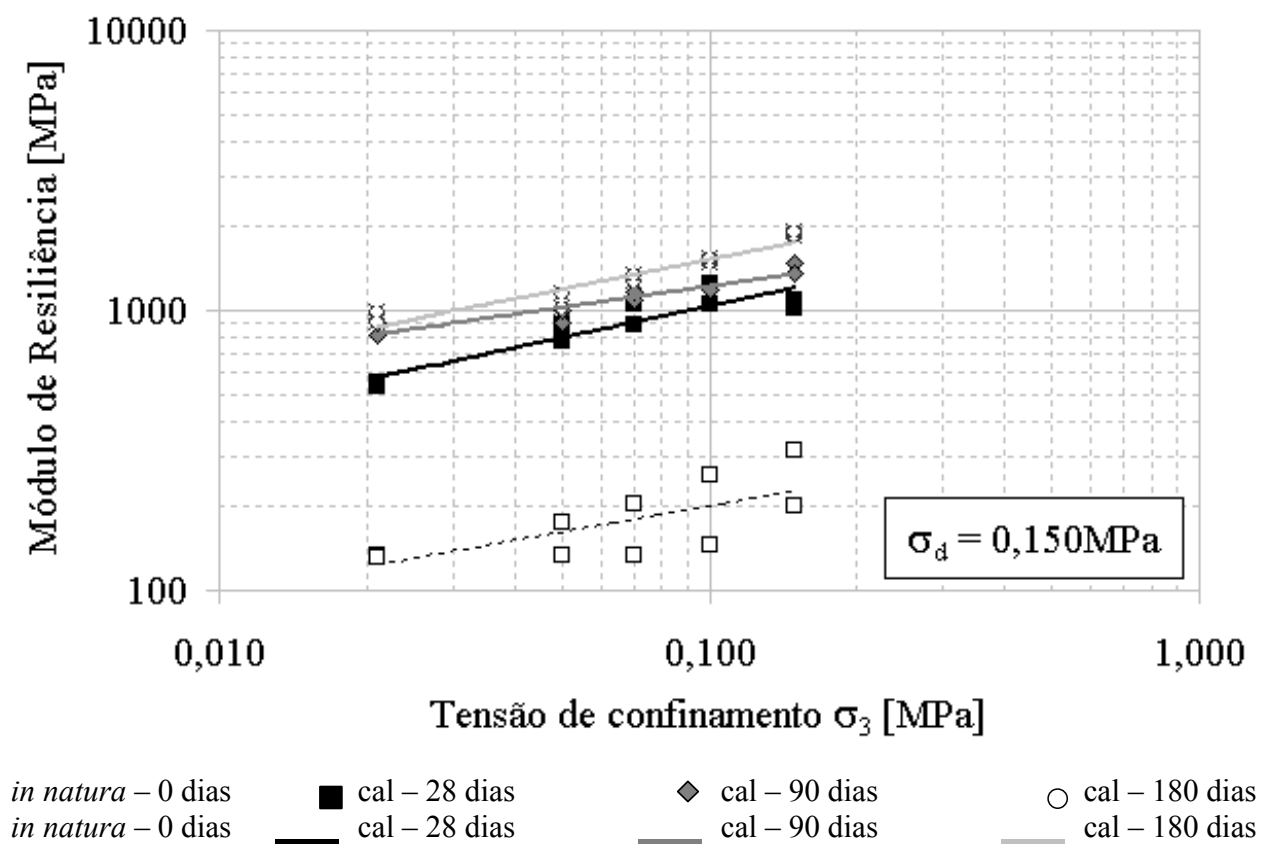

Figura 5.63: Evolução do Módulo de Resiliência com o tempo de cura em corpos-deprova com $4 \%$ de cal, para $\sigma_{\mathrm{d}}$ de $0,150 \mathrm{MPa}$

Na Figura 5.62 e na Figura 5.63, verifica-se que a incorporação de $4 \%$ de cal ao agregado reciclado tornou a mistura compactada mais rígida, e isto se refletiu em um considerável aumento do Módulo de Resiliência, em relação ao resultado obtido com o material in natura sem cura prévia (aos zero dias). 


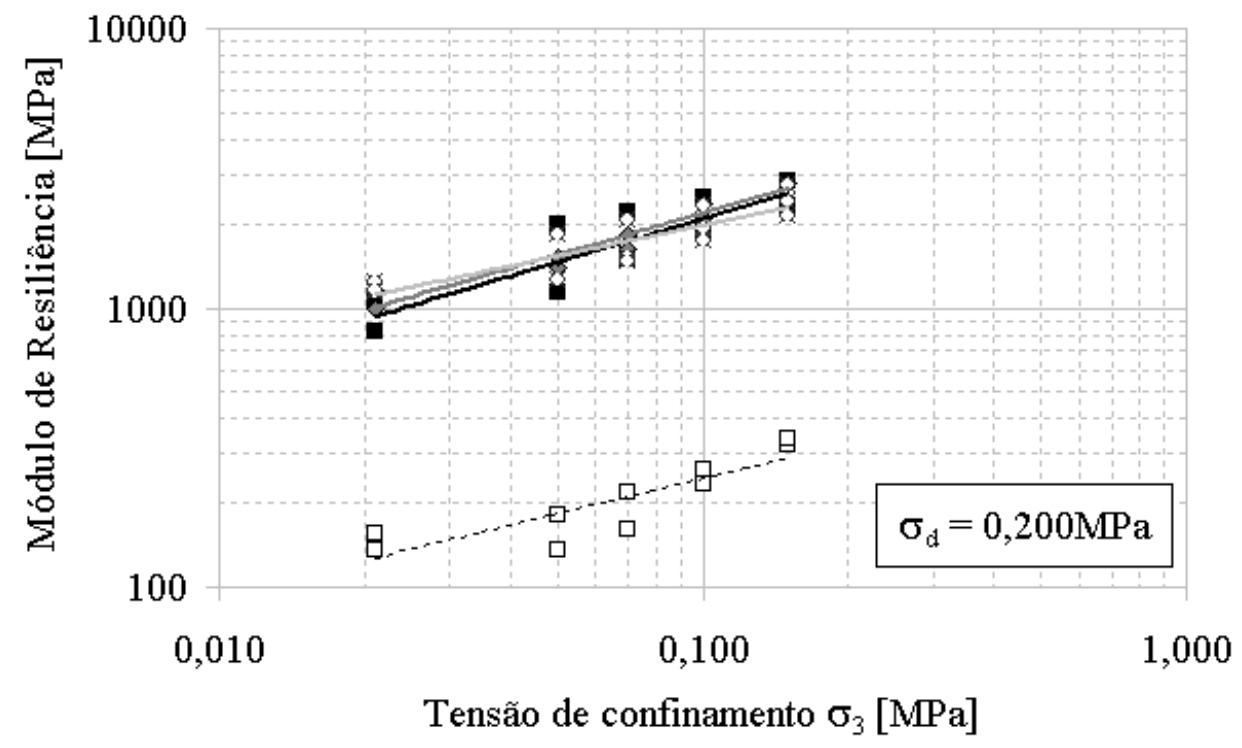

Figura 5.64: Evolução do Módulo de Resiliência com o tempo de cura em corpos-deprova com adição de $4 \%$ de cimento Portland, para $\sigma_{d}$ de $0,200 \mathrm{MPa}$

\begin{tabular}{|c|c|}
\hline $\begin{array}{r}\square \text { in natura }-0 \text { dias } \\
-- \text { in natura }-0 \text { dias }\end{array}$ & $\begin{array}{l}\text { cimento Portland }-28 \text { dias } \\
\text { cimento Portland }-28 \text { dias }\end{array}$ \\
\hline$\diamond$ cimento Portland - 90 dias & to Portland - 18 \\
\hline
\end{tabular}

Na Figura 5.64, embora tenha ocorrido uma certa dispersão dos resultados, para $\sigma_{3}$ de $0,227 \mathrm{MPa}$ e $\sigma_{\mathrm{d}}$ igual a $0,200 \mathrm{MPa}$ (tensões na base do pavimento estudado), temse que o Módulo de Resiliência do material com 4\% de cimento Portland, ao se extrapolar as linhas de tendência, praticamente não varia em todos os tempos de cura testados.

Já para $\sigma_{3}$ de $0,125 \mathrm{MPa}$ e $\sigma_{\mathrm{d}}$ igual a $0,150 \mathrm{MPa}$ (tensões na sub-base do pavimento analisado), o Módulo de Resiliência se apresentou da mesma forma que no caso anterior das tensões na base, onde a variação com o tempo de cura foi mínima (Figura 5.65). 


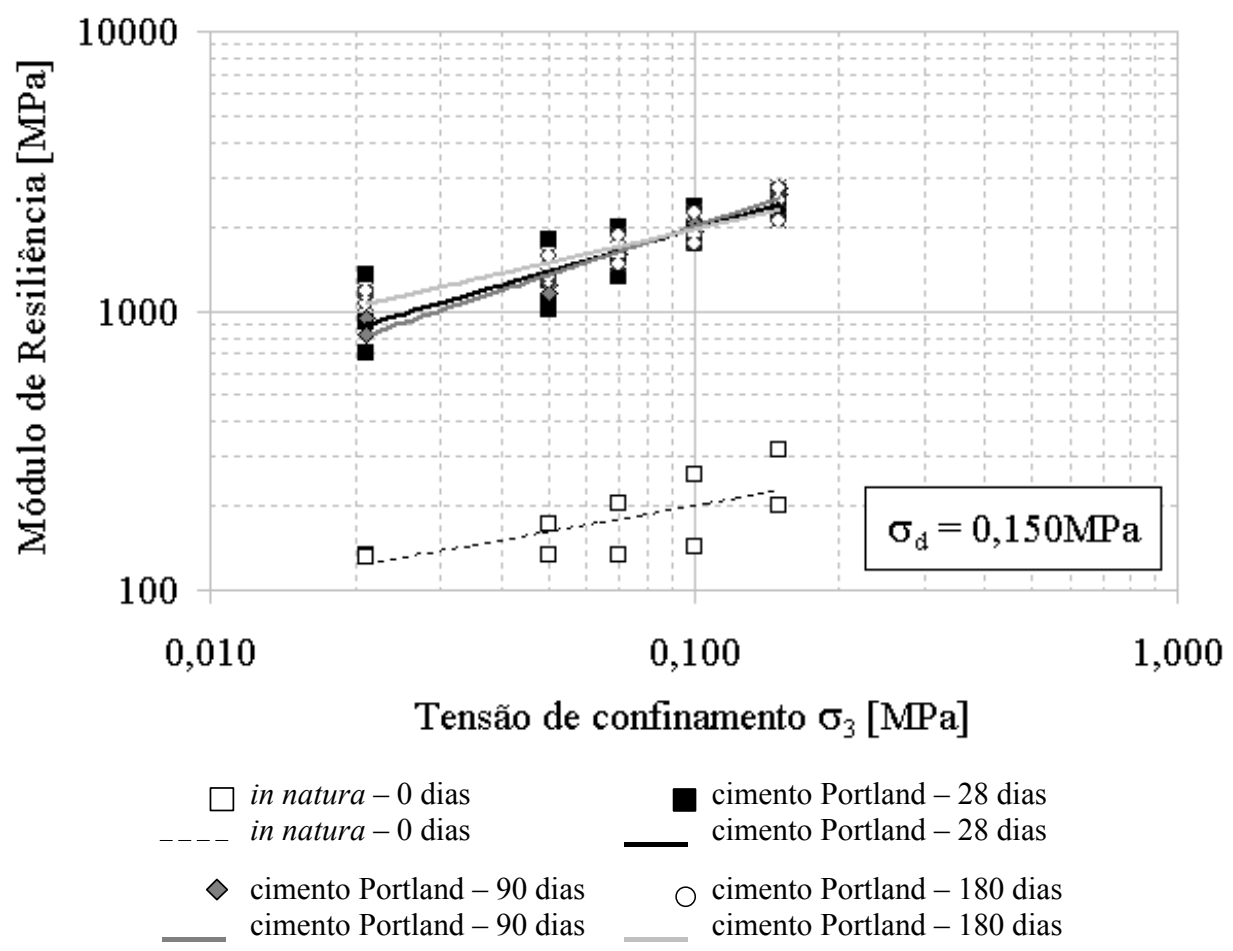

Figura 5.65: Evolução do Módulo de Resiliência com o tempo de cura em corpos-deprova com adição de $4 \%$ de cimento Portland, para $\sigma_{\mathrm{d}}$ de $0,150 \mathrm{MPa}$

Assim como no caso do material com 4\% de cal, a incorporação de $4 \%$ de cimento Portland ao agregado reciclado tornou a mistura compactada mais rígida, provocando um aumento significativo de seu Módulo de Resiliência em comparação com o material in natura sem cura prévia, que é o material de referência.

Como forma de observar a variação do Módulo de Resiliência em função do tempo de cura, da Figura 5.66 à Figura 5.71 tem-se os diferentes materiais estudados agrupados conforme o tempo de cura, para os mesmos $\sigma_{\mathrm{d}}$ observados anteriormente. 


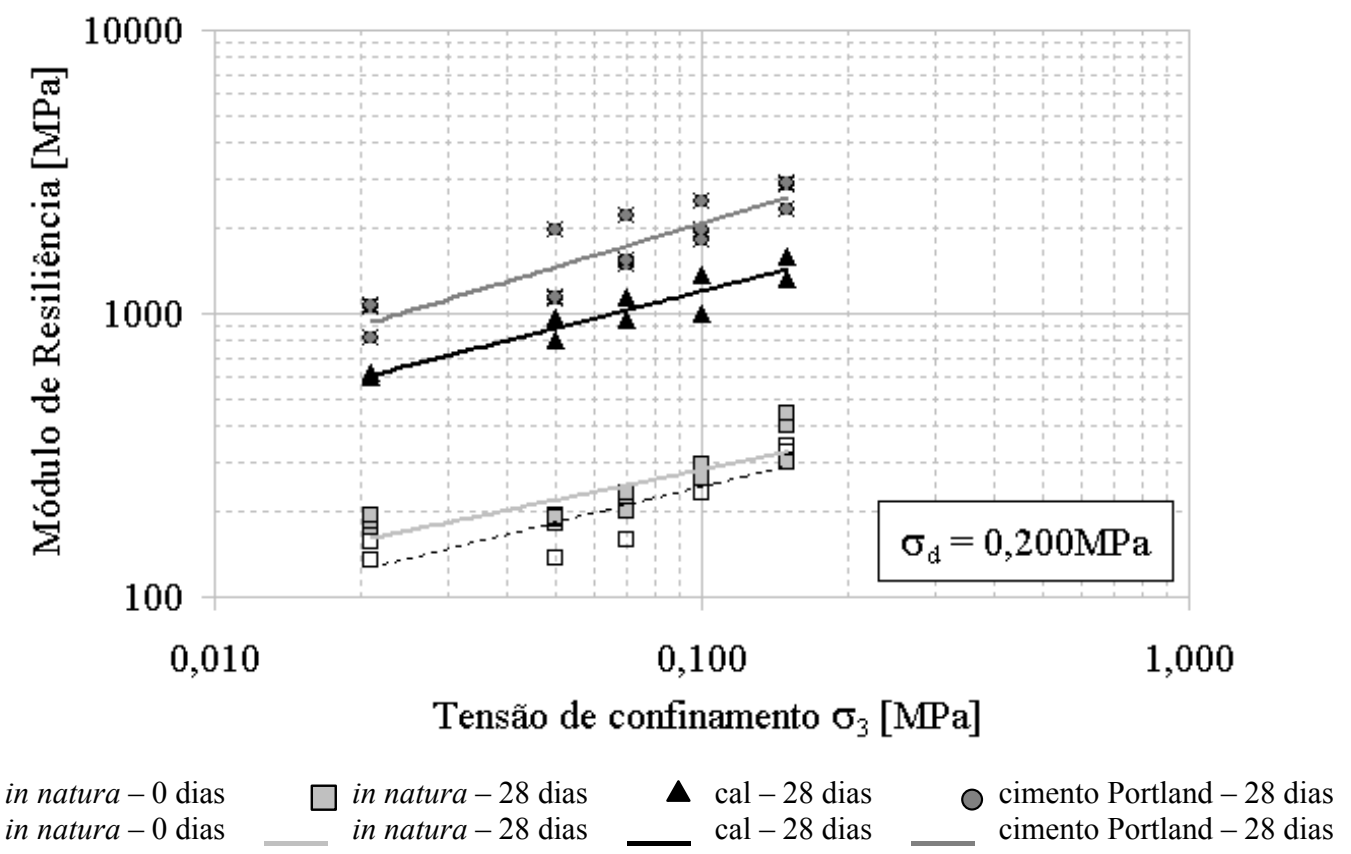

Figura 5.66: Módulo de Resiliência após cura de 28 dias em corpos-de-prova in natura, com $4 \%$ de cal e com $4 \%$ de cimento Portland, para $\sigma_{\mathrm{d}}$ de $0,200 \mathrm{MPa}$

$\mathrm{Na}$ Figura 5.66, para $\sigma_{3}$ de $0,227 \mathrm{MPa}$ e $\sigma_{\mathrm{d}}$ de $0,200 \mathrm{MPa}$ (tensões na base do pavimento estudado), verifica-se que aos 28 dias os materiais in natura, com 4\% de cal e com 4\% de cimento Portland tiveram seus Módulos de Resiliência aumentados, em relação ao material de referência, em cerca de $8 \%, 5$ vezes e 9 vezes, respectivamente, embora tenha ocorrido uma certa dispersão dos resultados.

Já no caso de $\sigma_{3}$ igual a $0,125 \mathrm{MPa}$ e de $\sigma_{\mathrm{d}} 0,150 \mathrm{MPa}$ (tensões na sub-base do pavimento analisado), o crescimento chegou a ser de aproximadamente 2 vezes no caso do material in natura, 5 vezes com a adição de 4\% de cal, e 11 vezes com a incorporação de 4\% de cimento Portland (Figura 5.67). 


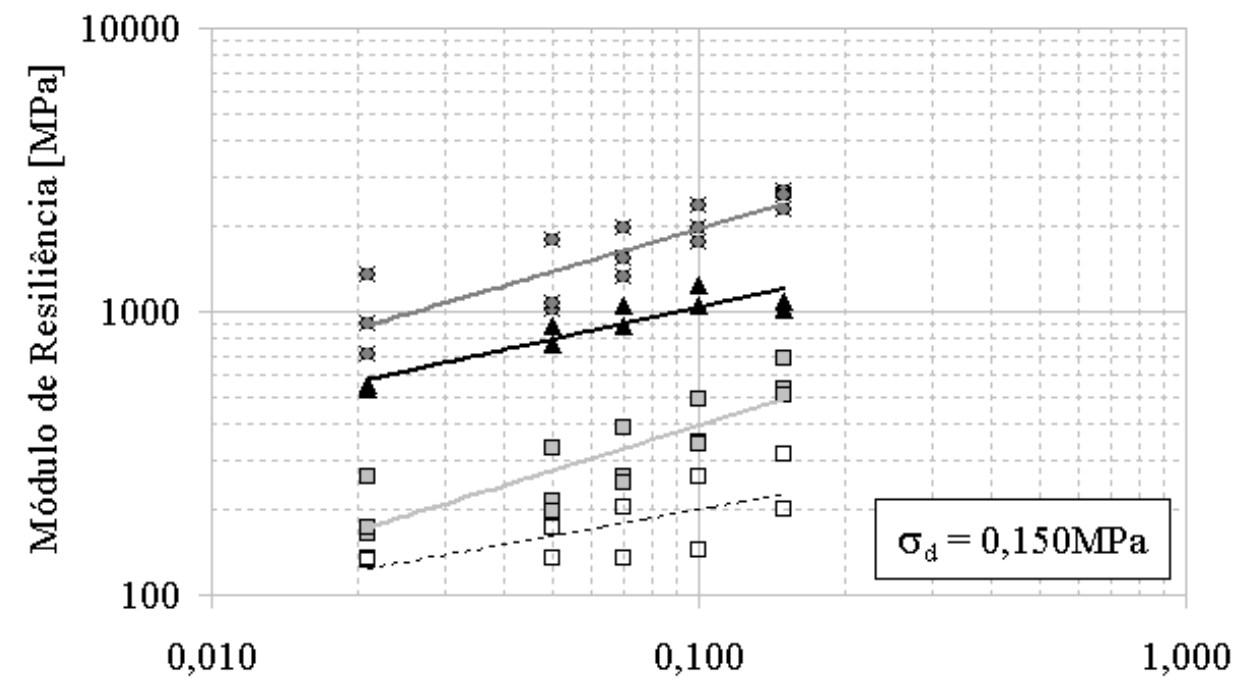

Tensão de confinamento $\sigma_{3}[\mathrm{MPa}]$

$\square$ in natura -0 dias in natura - 0 dias in natura - 28 dias in natura -28 dias
$\Delta$ cal -28 dias cal -28 dias cimento Portland - 28 dias cimento Portland - 28 dias

Figura 5.67: Módulo de Resiliência após cura de 28 dias em corpos-de-prova in natura, com $4 \%$ de cal e com $4 \%$ de cimento Portland, para $\sigma_{\mathrm{d}}$ de $0,150 \mathrm{MPa}$

Em relação aos 90 dias de cura, observa-se na Figura 5.68 que, para $\sigma_{3}$ igual a 0,227 MPa e $\sigma_{\mathrm{d}}$ de $0,200 \mathrm{MPa}$ (tensões na base do pavimento estudado), o Módulo de Resiliência cresceu cerca de 1,5 vezes no caso do material in natura, 5 vezes com a adição de 4\% de cal e 9,5 vezes com a incorporação de 4\% de cimento Portland. 


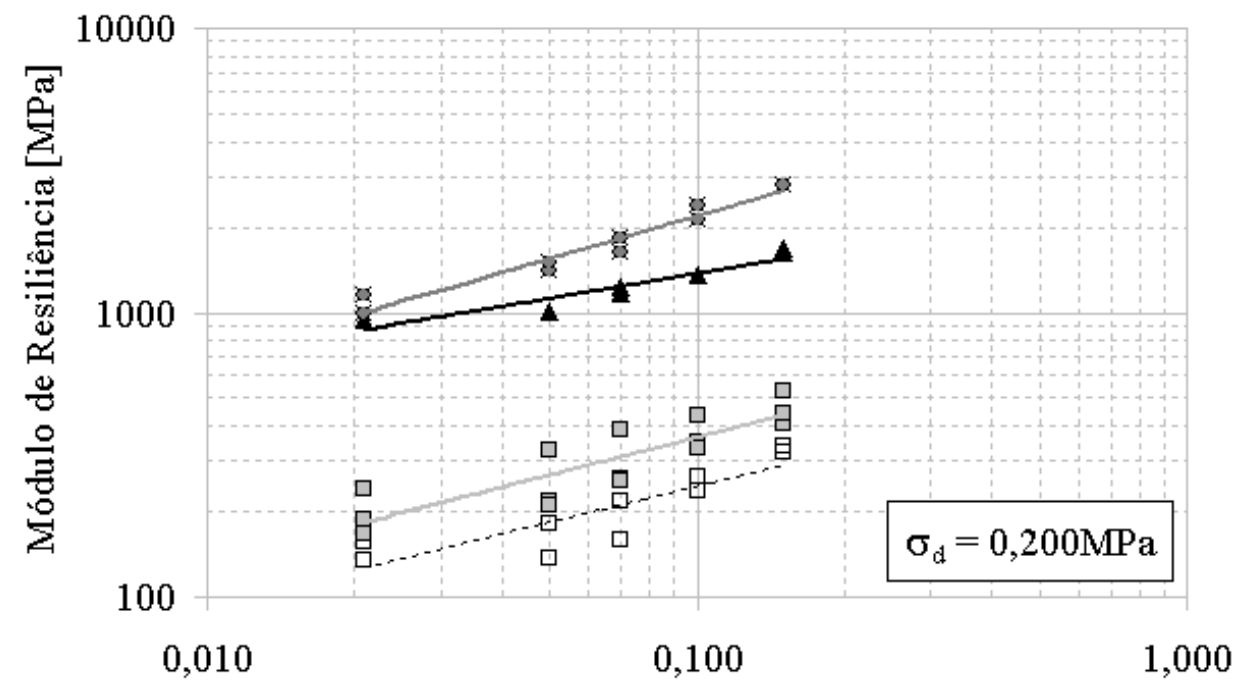

Tensão de confinamento $\sigma_{3}[\mathrm{MPa}]$

$\square$ in natura - 0 dias in natura - 0 dias in natura - 90 dias in natura - 90 dias
$\Delta$ cal - 90 dias cal - 90 dias
- cimento Portland - 90 dias cimento Portland - 90 dias

Figura 5.68: Módulo de Resiliência após cura de 90 dias em corpos-de-prova in natura, com $4 \%$ de cal e com $4 \%$ de cimento Portland, para $\sigma_{\mathrm{d}}$ de $0,200 \mathrm{MPa}$

Já para $\sigma_{3}$ igual a $0,125 \mathrm{MPa}$ e $\sigma_{\mathrm{d}}$ de $0,150 \mathrm{MPa}$ (tensões na sub-base do pavimento analisado), nota-se que o Módulo de Resiliência aos 90 dias de cura cresceu em torno de 2 vezes no caso do material in natura, 6 vezes com a adição de 4\% de cal, e 10 vezes com a incorporação de $4 \%$ de cimento Portland, em relação ao material de referência (Figura 5.69). 


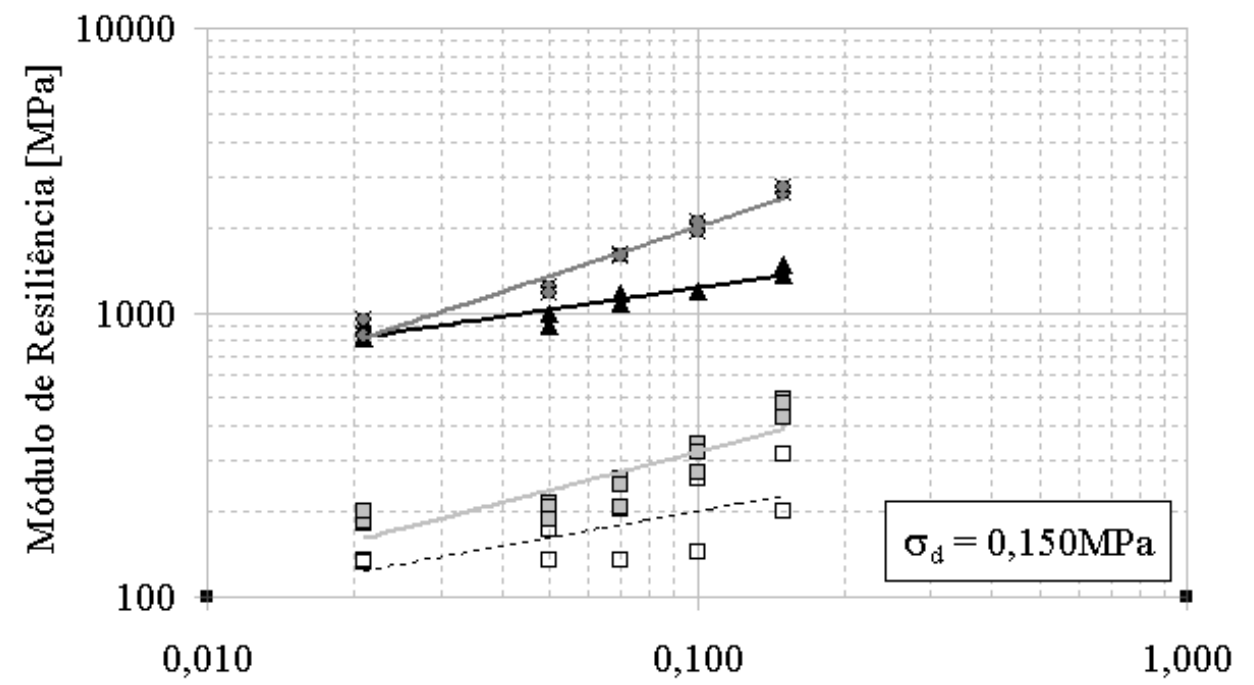

Tensão de confinamento $\sigma_{3}[\mathrm{MPa}]$

$\square$ in natura -0 dias in natura - 0 dias in natura - 90 dias in natura - 90 dias
$\Delta$ cal - 90 dias cal - 90 dias o cimento Portland - 90 dias cimento Portland - 90 dias

Figura 5.69: Módulo de Resiliência após cura de 90 dias em corpos-de-prova in natura, com $4 \%$ de cal e com $4 \%$ de cimento Portland, para $\sigma_{\mathrm{d}}$ de $0,150 \mathrm{MPa}$

Aos 180 dias de cura, observa-se na Figura 5.70 que, para $\sigma_{3}$ igual a 0,227MPa e $\sigma_{d}$ de 0,200MPa (tensões na base do pavimento estudado), o Módulo de Resiliência ainda sofreu aumento, que ficou em cerca de 1,5 vezes no caso do material in natura, 6,5 vezes com a adição de $4 \%$ de cal e em 8 vezes com a adição de $4 \%$ de cimento Portland. 


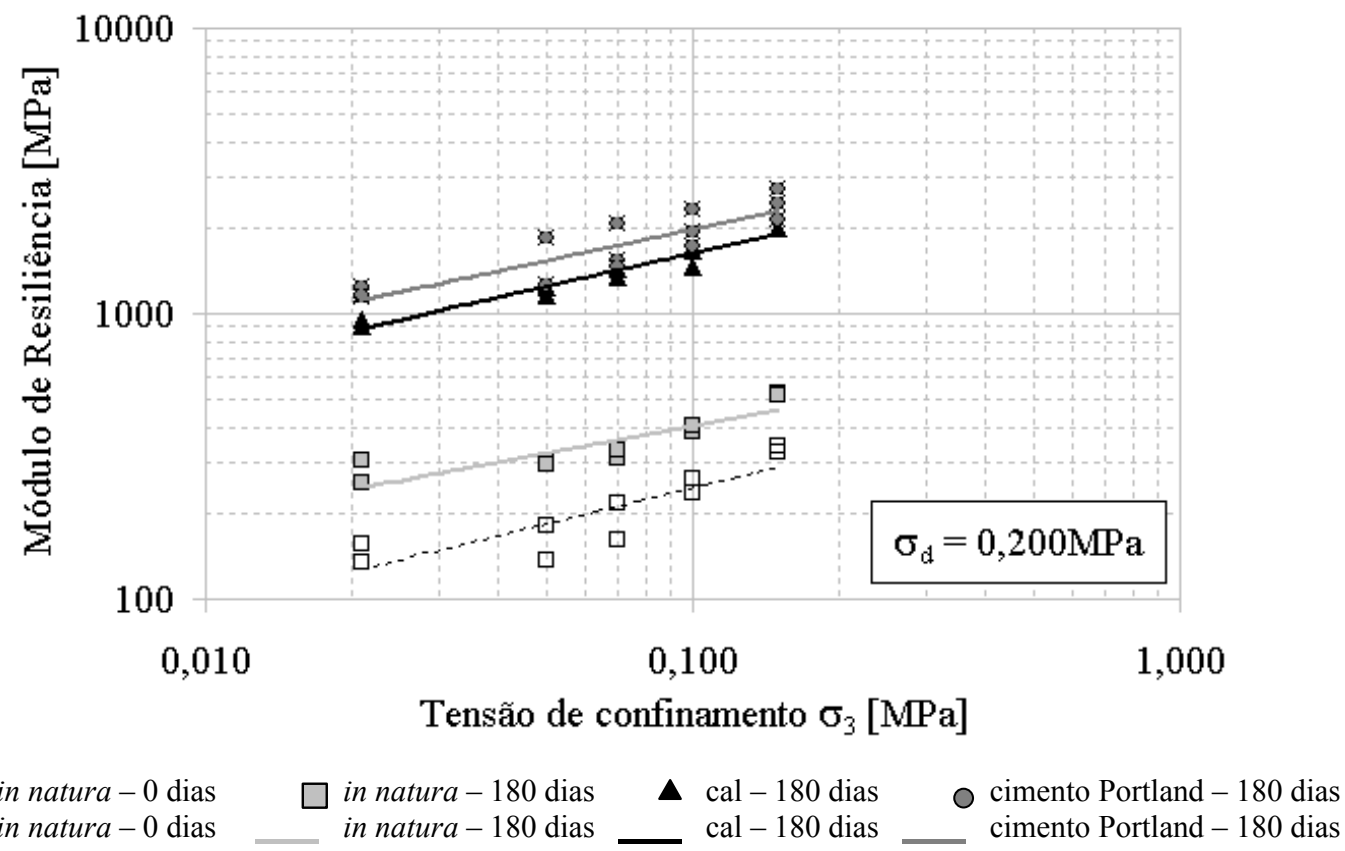

Figura 5.70: Módulo de Resiliência após cura de 180 dias em corpos-de-prova in natura, com cal e cimento Portland, para $\sigma_{\mathrm{d}}$ de $0,200 \mathrm{MPa}$

Ainda para 180 dias de cura, com $\sigma_{3}$ igual a $0,125 \mathrm{MPa}$ e $\sigma_{\mathrm{d}}$ de $0,150 \mathrm{MPa}$ (tensões na sub-base do pavimento analisado), o Módulo de Resiliência cresceu aproximadamente 2,5 vezes no caso do material in natura, 8 vezes com a adição de $4 \%$ de cal, e 10 vezes com a incorporação de $4 \%$ de cimento Portland, em relação ao material de referência (Figura 5.71). 


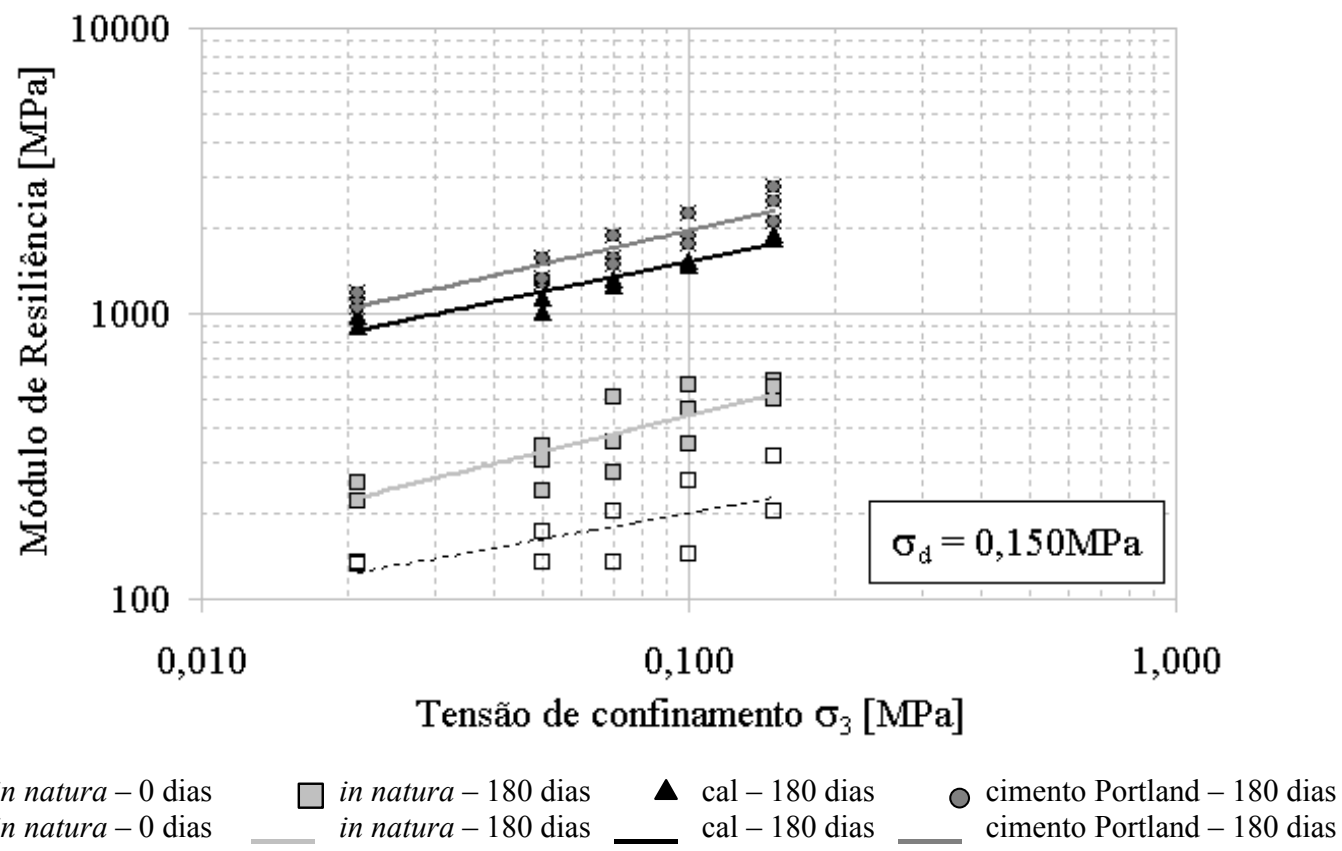

Figura 5.71: Módulo de Resiliência após cura de 180 dias em corpos-de-prova in natura, com $4 \%$ de cal e $4 \%$ de cimento Portland, para $\sigma_{\mathrm{d}}$ de $0,150 \mathrm{MPa}$

De maneira geral, em todos os casos analisados neste item referente ao Módulo de Resiliência, o material in natura apresentou ganho neste quesito com o tempo de cura. Como este resultado se refere a um material em que não foi adicionado aglomerante, há indícios de que houve reação pozolânica por parte de partículas que ainda possuíam potencial reativo. E esta pozolanicidade possivelmente foi provocada pela adição de água para atingir o teor de umidade e pela compactação que tende a aumentar a finura do agregado reciclado, segundo os princípios descritos no item 5.4.4.

Com o aumento do tempo de cura, as diferenças entre os Módulos de Resiliência da mistura com $4 \%$ de cimento Portland e os da material de referência (in natura sem cura prévia) foram diminuindo, exceto no caso das tensões na sub-base aos 180 dias.

Verifica-se ainda que o agregado reciclado, em todos os tempos de cura analisados, é igualmente afetado pela tensão de confinamento aplicada, estando em sua forma in natura ou mesmo misturado a $4 \%$ de cal ou $4 \%$ de cimento Portland. 
A Instrução de Projeto da PMSP - IP-08 (2002) apresenta estimativas de valores de Módulo de Resiliência para materiais granulares, para que seus projetistas possam avaliar deformações, tensões e deflexões na estrutura do pavimento. De acordo com o documento citado, a estimativa do Módulo de Resiliência (ou Módulo de Elasticidade, como referido) para uma camada de base granular apresenta-se entre $100 \mathrm{MPa}$ e 500MPa, de acordo com a expressão (6).

$100 \leq E_{B} \leq 500$

onde:

$E_{B}$ é o Módulo de Resiliência (ou de Elasticidade) da base granular, em [MPa].

Com a expressão (7), verifica-se que todos os Módulos de Resiliência obtidos pelo agregado reciclado, seja em sua forma in natura ou com a adição de $4 \%$ de cal ou 4\% de cimento Portland, apresentam-se maiores que o valor mínimo, ultrapassando significativamente os $500 \mathrm{MPa}$ estimados quando há a incorporação dos aglomerantes.

Bennert et al. (2000) também realizaram ensaio de Módulo de Resiliência com agregados reciclados, porém de concreto, da cidade norte-americana de New Jersey, cujos resultados apontaram valores entre $200 \mathrm{MPa}$ e 500MPa, aproximadamente, para tensões de confinamento de $0,021 \mathrm{MPa}$ e $0,138 \mathrm{MPa}$, respectivamente. Estes números se assemelham àqueles obtidos no presente estudo com o material in natura (embora não seja especificamente de concreto) aos 90 dias de cura.

Reid (2000) apresenta resultados obtidos em uma pesquisa de campo feita na Suécia, com o objetivo de analisar a evolução do Módulo de Resiliência por meio de $F W D$, de sub-base constituída de agregados reciclados de concreto. Notou-se um aumento da rigidez da camada com o tempo, principalmente nos primeiros cinco meses, caracterizada pelas propriedades cimentantes do material (Figura 5.72). 
Capacidade de suporte

Módulo de Resiliência medido através de FWD. Rodovia 109 em EKEBY.

Camadas de sub-base.

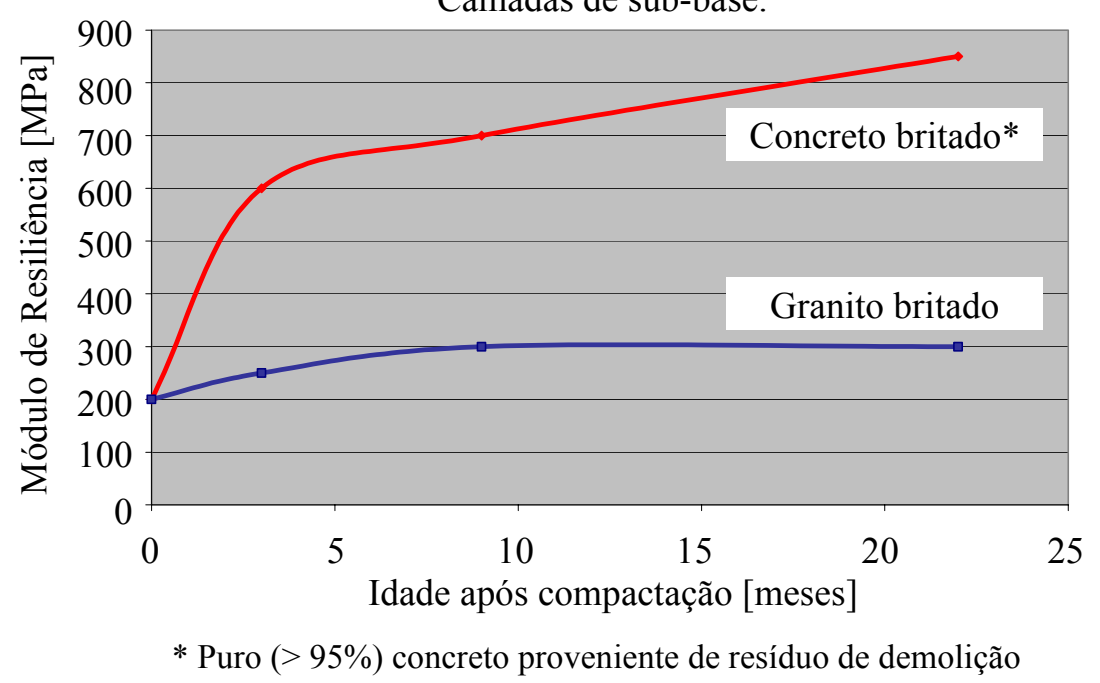

Figura 5.72: Resultados de Módulo de Resiliência em campo, para agregados reciclados de concreto, segundo figura retirada de Reid (2000), com modificações

Ainda em um outro estudo de campo com agregados reciclados de concreto, realizado por Arm (2001) na Suécia, verificou-se também um significativo aumento do Módulo de Resiliência do material com o tempo, principalmente nas primeiras idades (Figura 5.73). A pesquisa, que ainda incluiu a análise em laboratório, mostrou que o incremento da resistência se apresenta consideravelmente maior em campo do que em ensaios de laboratório. Além disso, concluiu-se ainda que o módulo da camada, dois anos após sua construção, é cerca de duas vezes maior do que o alcançado após um mês. 


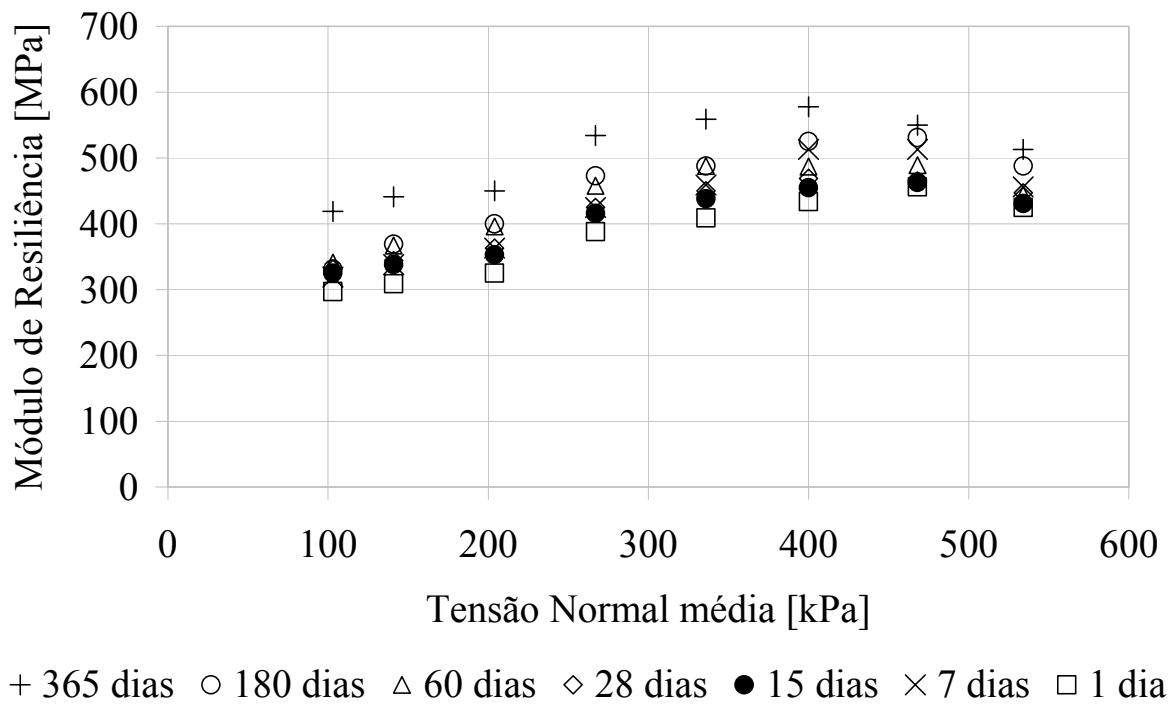

Figura 5.73: Resultados de Módulo de Resiliência de campo para agregados reciclados de concreto, segundo figura retirada de Arm (2001), com modificações

\subsection{Comparativo do agregado reciclado com a brita graduada}

A título de comparação, três dos experimentos realizados com agregados reciclados nesta pesquisa também foram executados com brita graduada de granulometria semelhante; são eles: variação do peso específico aparente seco com a energia de compactação, ISC e Módulo de Resiliência.

A brita graduada utilizada nesta pesquisa foi coletada na pedreira Sargon, que fica localizada no município de Santa Isabel (SP), e era de origem granítica.

\subsubsection{Granulometria da brita graduada}

Para a composição granulométrica da brita graduada, fez-se uso de cinco tipos de britas (Tabela 5.15), de forma que a graduação se assemelhasse à do agregado reciclado (Figura 5.74). 
Tabela 5.15: Diâmetro dos diferentes tipos de brita utilizados para compor a brita graduada

\begin{tabular}{|c|c|}
\hline Tipo de material pétreo & $\begin{array}{c}\text { Faixa de enquadramento } \\
\text { de diâmetro dos grãos }\end{array}$ \\
\hline Brita 3 & $38,1 \mathrm{~mm}-25,4 \mathrm{~mm}$ \\
\hline Brita 2 & $25,4 \mathrm{~mm}-12,5 \mathrm{~mm}$ \\
\hline Brita 1 & $12,5 \mathrm{~mm}-9,52 \mathrm{~mm}$ \\
\hline Pedrisco & $4,76 \mathrm{~mm}-2,38 \mathrm{~mm}$ \\
\hline Pó-de-pedra & abaixo de $2,38 \mathrm{~mm}$ \\
\hline \hline
\end{tabular}

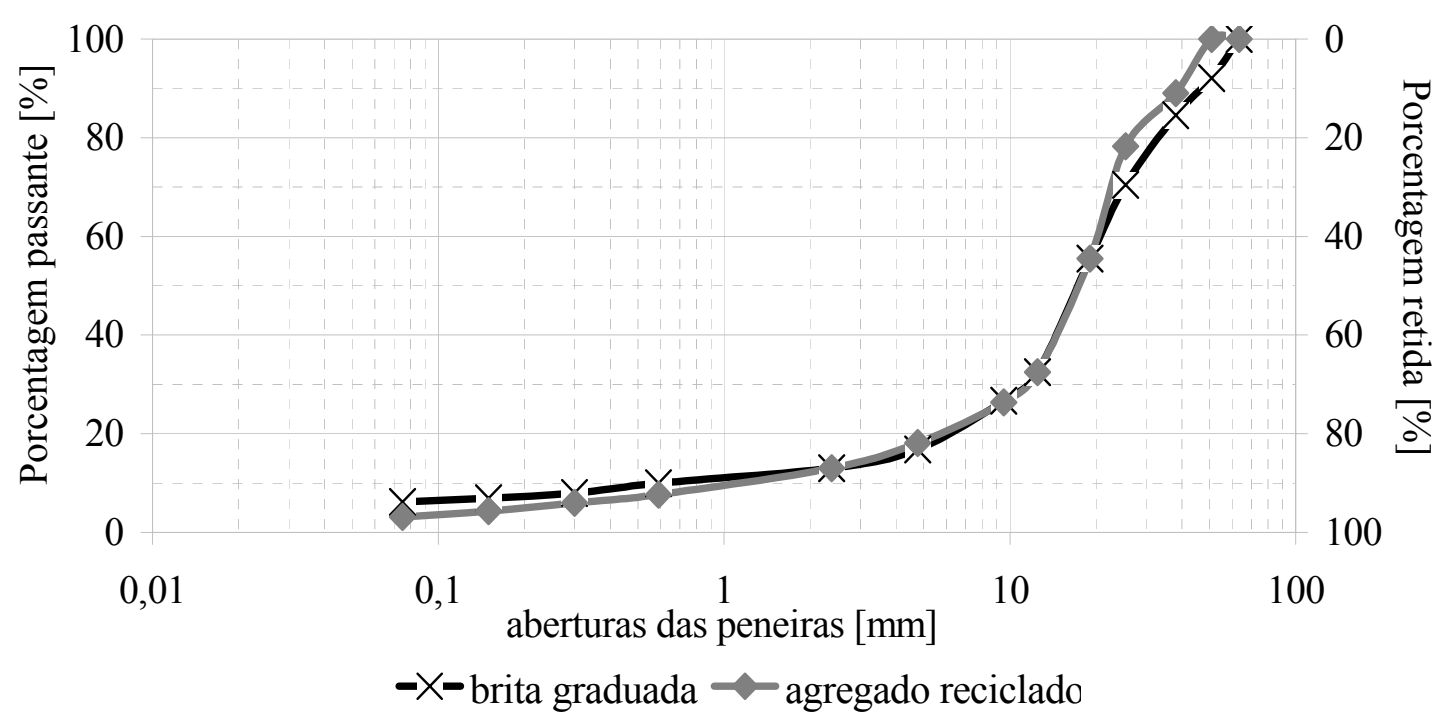

Figura 5.74: Curva granulométrica da brita graduada e do agregado reciclado estudados

Verificou-se que não houve enquadramento da brita graduada analisada nas faixas especificadas pela NBR 11806 (1991) e seção 3.06 do DER-SP (1991) para brita graduada, e também pela NBR 18804 (1991) e seção 3.04 do DER-SP (1991) para materiais estabilizados granulometricamente (Figura 5.75). 


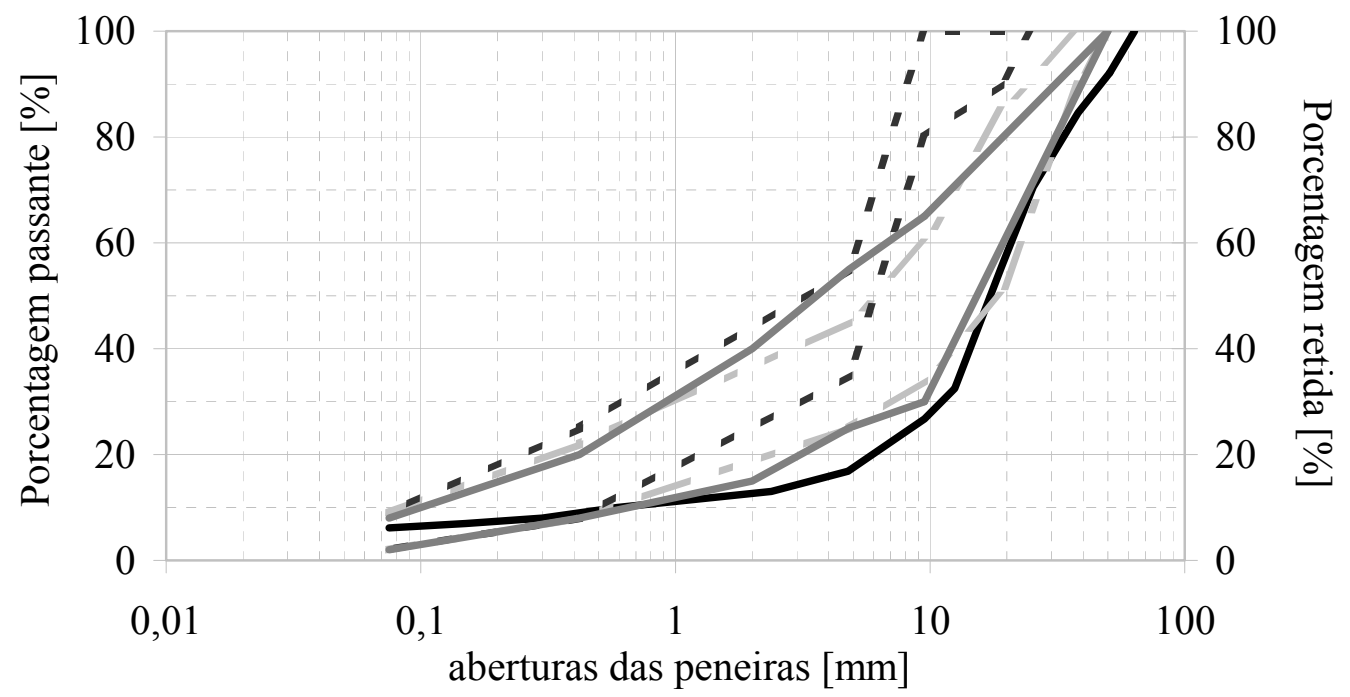

- Brita graduada da pesquisa

Brita graduada DER-SP e faixa A da ABNT

- - "Brita graduada faixa B da ABNT

- $=$ Material estabilizado granulometricamente DER-SP e faixa A da ABNT

Figura 5.75: Curva granulométrica da brita graduada pesquisada frente às faixas especificadas pela ABNT e pelo DER-SP

\subsubsection{Variação do peso específico aparente seco com a energia de compactação da brita graduada}

Neste experimento, já descrito em detalhes no item 5.7, as condições de ensaio impostas à brita graduada foram as mesmas do agregado reciclado, com exceção do teor de umidade, pois utilizou-se 3\%.

A Figura 5.76 apresenta as curvas de peso específico aparente seco por número de golpes, obtidas no ensaio com brita graduada e também com agregado reciclado (esta já ilustrada anteriormente no item 5.7). 


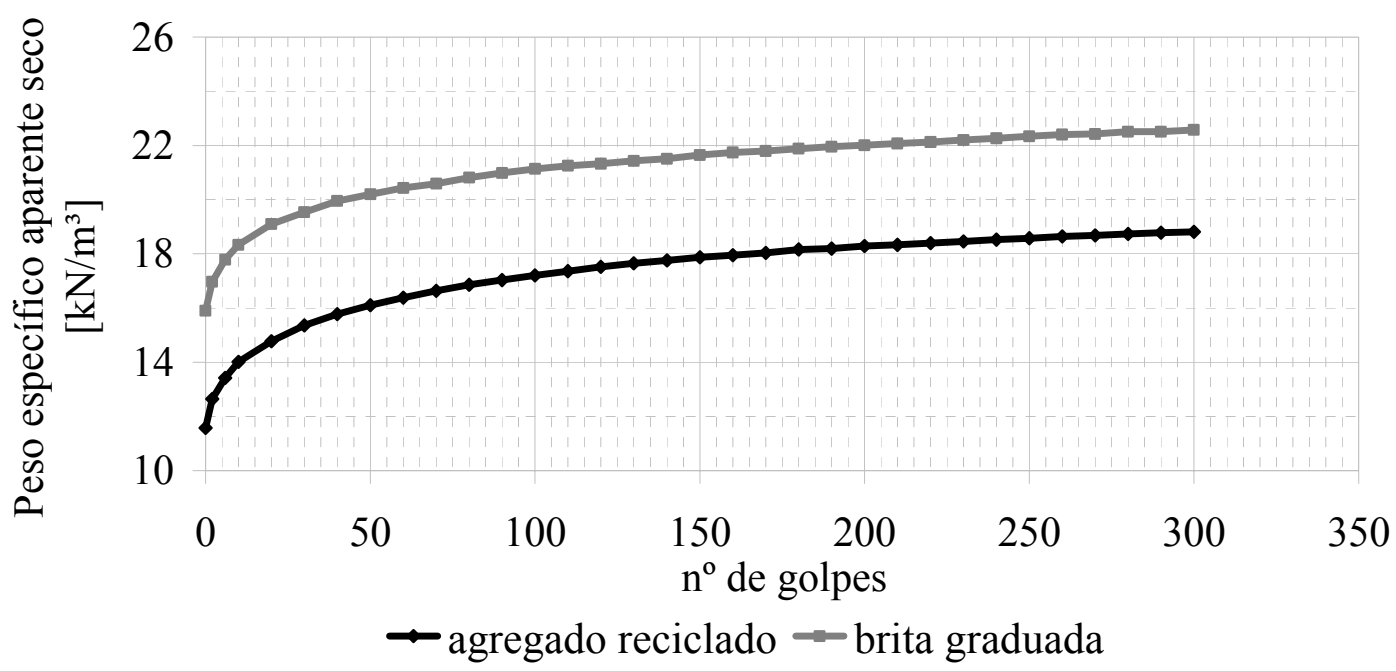

Figura 5.76: Comparação de resultados do ensaio MCV adaptado da brita graduada e do agregado reciclado estudados

Na Figura 5.76 é possível observar que a configuração da curva de brita graduada é muito semelhante à do agregado reciclado, apresentando inicialmente um aumento brusco do peso específico aparente seco com o aumento da energia de compactação, e tendendo à estabilização após cerca de 150 golpes.

O peso específico aparente seco da brita graduada estudada apresentou um valor inicial de $15,9 \mathrm{kN} / \mathrm{m}^{3}$, contra os $11,6 \mathrm{kN} / \mathrm{m}^{3}$ do agregado reciclado, e chegou aos 300 golpes com $22,6 \mathrm{kN} / \mathrm{m}^{3}$, ao invés dos $18,8 \mathrm{kN} / \mathrm{m}^{3}$ alcançados pelo agregado reciclado. Isto comprova que este material possui menor peso específico e maior porosidade que a brita graduada.

Posteriormente foi verificada a variação granulométrica da brita graduada, ocasionada pelo processo de compactação neste ensaio, como no caso do agregado reciclado. A Figura 5.77 e a Figura 5.78 apresentam as curvas que indicam a alteração de graduação do material, com base nas porcentagens passantes (ou retidas) e nas porcentagens retidas não acumuladas, respectivamente. 


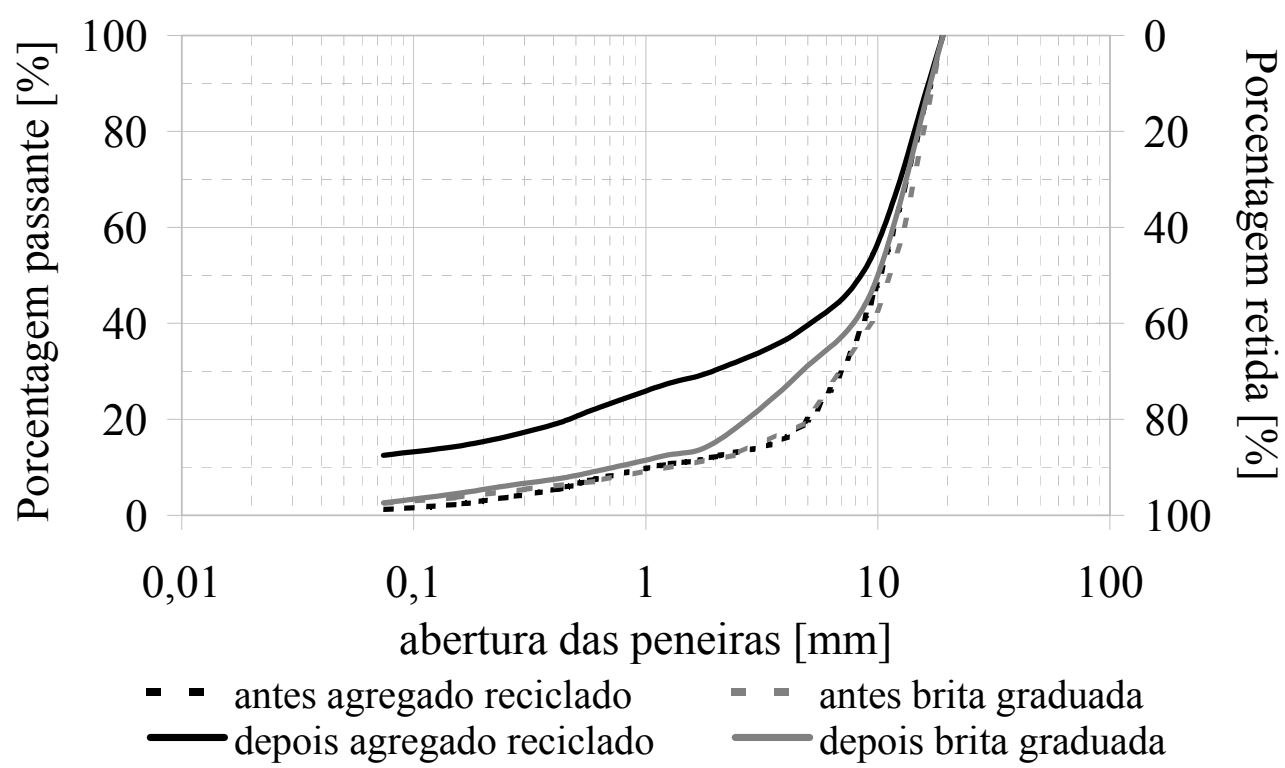

Figura 5.77: Variação granulométrica da brita graduada e do agregado reciclado após compactação em MCV adaptado, em porcentagens passantes (ou retidas)

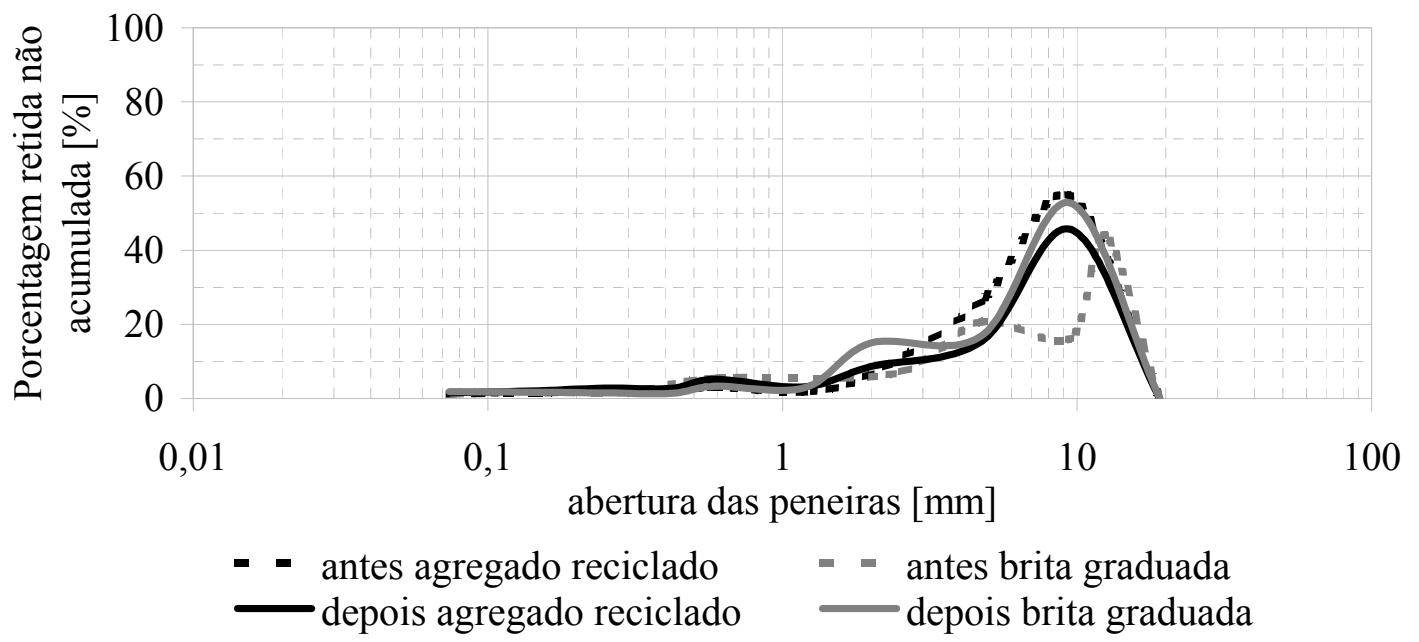

Figura 5.78: Variação granulométrica da brita graduada e do agregado reciclado após compactação em MCV adaptado, em porcentagens retidas não acumuladas

Por meio da Figura 5.77 e da Figura 5.78 é possível observar que, em ambas situações houve mudança significativa do diâmetro dos grãos perante a curva inicial, mas de forma mais acentuada no caso do agregado reciclado, como já era esperado. A brita graduada sofreu quebras mais acentuadas aproximadamente entre as peneiras $1,19 \mathrm{~mm}$ e $9,52 \mathrm{~mm}$, enquanto que no agregado reciclado as quebras se mostraram significativas em todos os diâmetros inferiores a 9,52mm, aproximadamente. 


\subsection{3 Índice de Suporte Califórnia (ISC) da brita graduada}

Neste experimento, já descrito em detalhes no item 5.8.1, as condições de ensaio impostas à brita graduada foram as mesmas do agregado reciclado, com exceção do teor de umidade, pois empregou-se $3 \%$.

Foram ensaiados 2 corpos-de-prova, sendo um compactado na energia Proctor Intermediária, que foi a mesma utilizada no caso do agregado reciclado, e outro na energia Proctor Modificada, usualmente empregada para brita graduada. A primeira corresponde à compactação em 5 camadas com 26 golpes por camada e a segunda em 5 camadas com 55 golpes por camada.

Os valores de ISC obtidos para a brita graduada nas energias Proctor Intermediária e Modificada encontram-se na Figura 5.79, juntamente com os do agregado reciclado, já apresentados anteriormente no item 5.8.1, para facilitar a comparação.

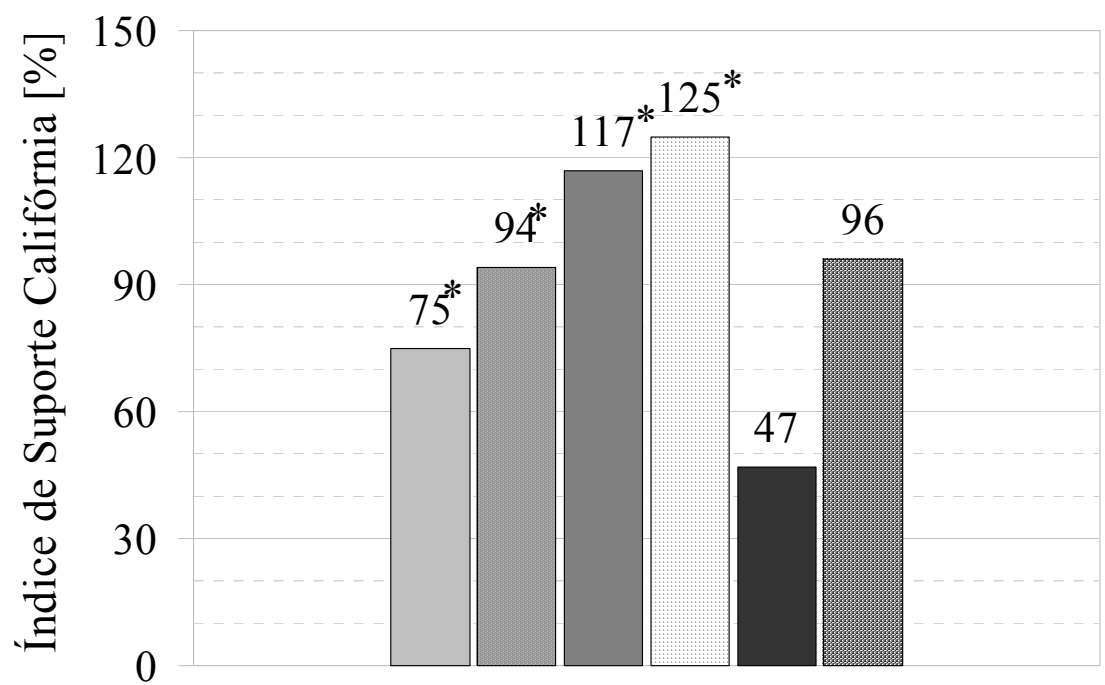

$\square$ agregado reciclado - energia Proctor Intermediária - 0 dias de cura $\square$ agregado reciclado - energia Proctor Intermediária - 28 dias de cura $\square$ agregado reciclado - energia Proctor Intermediária - 90 dias de cura $\square$ agregado reciclado - energia Proctor Intermediária - 180 dias de cura $\square$ brita graduada - energia Proctor Intermediária $\square$ brita graduada - energia Proctor Modificada

* Valor médio

Figura 5.79: Comparativo entre ISC da brita graduada e do agregado reciclado 
Os valores apontados na Figura 5.79 mostram que o agregado reciclado aos zero dias de cura apresentou ISC significativamente superior (75\%) ao da brita graduada também compactada na energia Proctor Intermediária (47\%).

Aos 28 dias de cura, o agregado reciclado compactado na energia Proctor Intermediária alcançou valor de ISC próximo ao da brita graduada compactada na Proctor Modificada (94 e 96\%, respectivamente).

Já o agregado reciclado aos 90 e 180 dias de cura apresentaram ISC maior (117\% e $125 \%$, respectivamente) que o da brita graduada compactada na energia Proctor Intermediária e na Modificada ( $47 \%$ e $96 \%$, respectivamente).

Ao observar os resultados de ISC obtidos com a brita graduada compactada em ambas energias, nota-se que a capacidade de suporte deste material quando da aplicação de Proctor Intermediária é consideravelmente menor que com o uso de Proctor Modificada. Desta forma, para que a brita graduada seja empregada em seu máximo potencial, o uso de energia Proctor Modificada em sua compactação é mais adequado, uma vez que este material apresenta preço superior ao de outros materiais convencionais por ser considerado nobre em pavimentação.

\subsubsection{Módulo de Resiliência da brita graduada}

Neste experimento, descrito de forma mais detalhada no item 5.8.4, as condições de ensaio impostas à brita graduada foram as mesmas do agregado reciclado, com exceção do teor de umidade, pois empregou-se $3 \%$, e da necessidade de congelamento do corpo-de-prova previamente ao ensaio para que o mesmo não sofresse desagregação de sua estrutura entre a fase de desmoldagem e a de posicionamento na câmera triaxial.

Foram ensaiados 2 corpos-de-prova, sendo um compactado na energia Proctor Intermediária, que foi a mesma utilizada no caso do agregado reciclado, e outro na energia Proctor Modificada, que é a energia usualmente empregada para brita graduada. Como a moldagem foi feita em cilindro de $150 \mathrm{~mm}$ de altura por $300 \mathrm{~mm}$ 
de diâmetro, as compactações foram feitas em 6 camadas com 57 golpes por camada e em 6 camadas com 115 golpes por camada para obter energias equivalentes à Proctor Intermediária e Modificada, respectivamente.

Os resultados do experimento com a brita graduada compactada nas duas energias são apresentados na Figura 5.80. As expressões contidas no gráfico se baseiam no modelo apresentado por Medina (1997) para solos granulares ou arenosos. Neste modelo, o módulo de resiliência depende principalmente da tensão de confinamento $\sigma_{3}$.

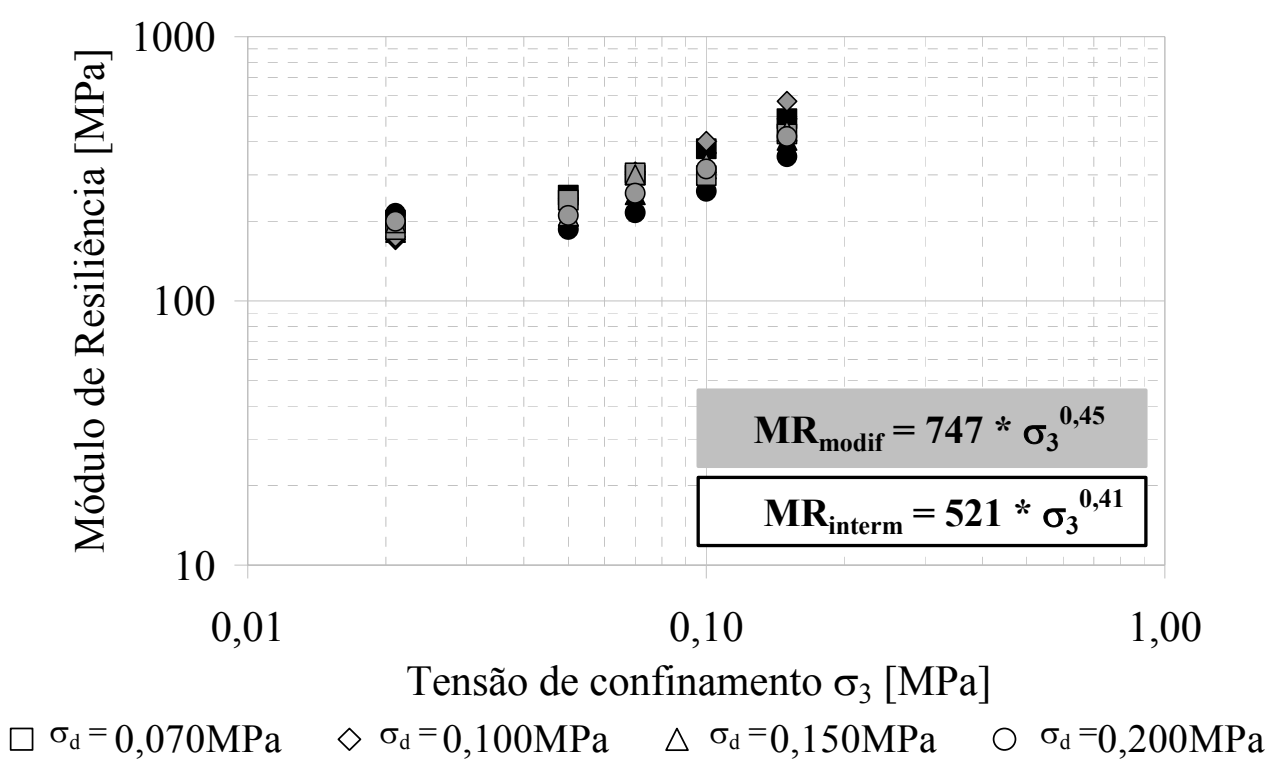

Figura 5.80: Módulo de Resiliência das britas graduadas compactadas em energias Proctor Modificada e Intermediária

Na Figura 5.80 verifica-se que os pontos do ensaio que expressam o Módulo de Resiliência se apresentaram de forma muito similar em ambas energias de compactação. Os valores se assemelham aos que foram encontrados com o agregado reciclado do tipo in natura aos 90 dias de cura.

A Figura 5.81 ilustra uma comparação entre os resultados de Módulo de Resiliência do agregado reciclado in natura em todos os tempos de cura $(0,28,90$ e 180 dias de cura) e a brita graduada, todos compactados em energia Proctor Intermediária. 


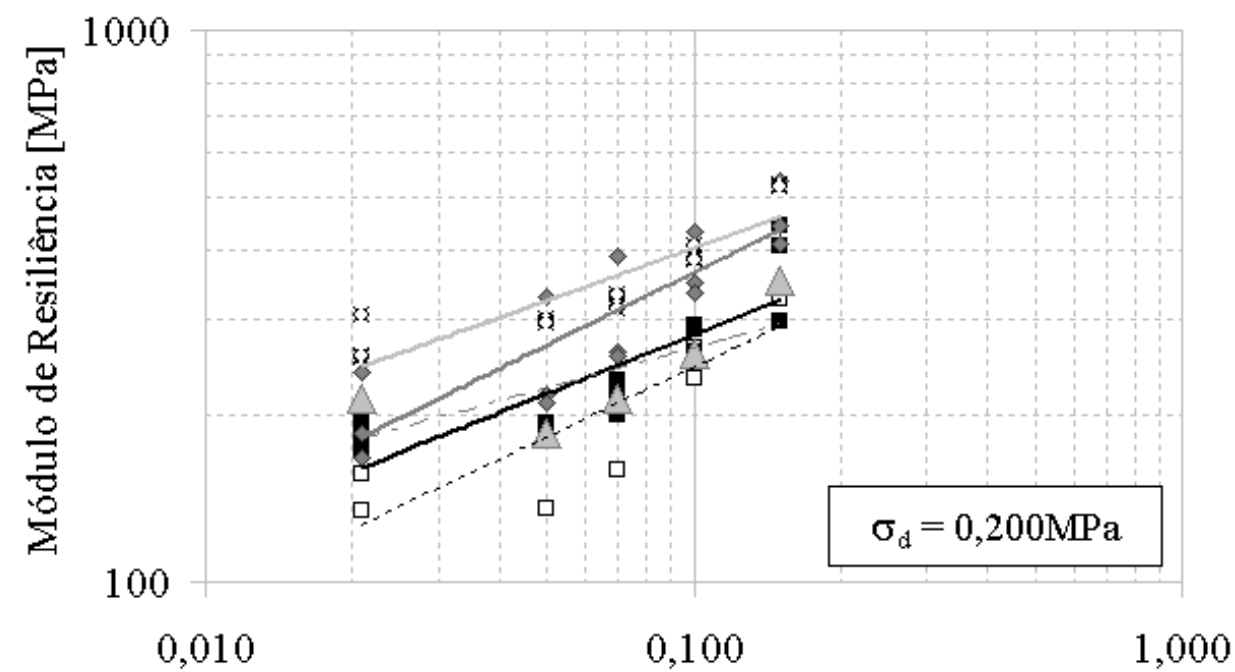

Tensão de confinamento $\sigma_{3}[\mathrm{MPa}]$

$\square$ in natura -0 dias
$\ldots \ldots . . . .$. in natura -0 dias

in natura -28 dias in natura -28 dias

$\diamond$ in natura -90 dias in natura -90 dias

O in natura - 180 dias in natura - 180 dias

$\triangle$ brita graduada brita graduada

Figura 5.81 Comparação de Módulo de Resiliência da brita graduada e do agregado reciclado in natura 


\section{CONCLUSÕES E COMENTÁRIOS}

Após a publicação da Resolução CONAMA (2002), que obriga os geradores a serem os responsáveis pelo resíduo produzido e que prescreve a necessidade de reutilização ou reciclagem do material, o emprego de agregados reciclados na construção de pavimentos pode ser interessante, principalmente porque obras de pavimentação consomem grandes quantidades de material e nelas podem ser utilizados todos os tipos de resíduo Classe A, nas mais diferentes granulometrias, ao contrário do que ocorre na produção de concreto, que é mais restritiva neste quesito.

Os ensaios realizados nesta pesquisa mostraram que grande parte do agregado reciclado estudado é composta de materiais cimentíceos - concreto e argamassa - e naturais britados. Encontrou-se também uma certa quantidade de componentes contaminantes no material coletado que, no entanto, era inferior aos limites máximos de aceitação estabelecidos pela NBR 15115 (2004). Deve-se atentar para os materiais indesejáveis que, estando presentes de forma significativa no montante de agregado reciclado, podem provocar problemas no pavimento, como por exemplo recalques diferenciais, e com isto influir no desempenho do mesmo.

Verificou-se que o agregado reciclado em geral absorve muita água (cerca de $8 \%$ ) em relação aos materiais pétreos convencionais (em torno de até $2 \%$ ), certamente devido à sua maior porosidade, e isto implica em necessidade de maior quantidade de água por ocasião da compactação.

Para teores de umidade acima de $11 \%$, o agregado reciclado estudado começou a mostrar sinais de saturação durante a preparação das amostras para o ensaio de compactação. O resultado deste ensaio mostrou que a curva de compactação não apresentou o tradicional pico máximo que indica a umidade ótima antes de alcançar o ramo úmido. Além disso, observou-se que a compactação promove significativa alteração da granulometria do agregado reciclado, para todos os teores de umidade testados e, teoricamente, a união dos pontos da curva de compactação não seria correta, pois o material é alterado ao longo de todo o processo e constitui-se em uma 
diferente graduação para cada estado de umidade de compactação. Ademais, as quebras mais importantes se deram logo nos primeiros estágios de compactação, ou seja, a partir da energia Proctor Normal, a aplicação de um maior número de golpes para se atingir a energia Proctor Intermediária implicou em uma quebra de grãos muito menos significativa, alterando pouco a distribuição granulométrica.

O agregado reciclado desta pesquisa mostrou atividade pozolânica de aproximadamente $130 \mathrm{mg}$ de $\mathrm{CaO}$ consumidos que, embora abaixo do limite mínimo de 330mg de $\mathrm{CaO} / \mathrm{g}$ para ser considerado uma pozolana segundo o Método de Chapelle Modificado, não deve ser descartada a hipótese de que a pozolanicidade deste material influa positivamente na resistência do pavimento. $\mathrm{O}$ valor mínimo especificado pelo Método de Chapelle Modificado foi idealizado para o concreto, cujos valores de resistência são extremamente elevados. Assim, um ganho de resistência que pode ser considerado baixo para o concreto pode não o ser para um pavimento.

Ainda que o agregado reciclado tenha apresentado valor de abrasão "Los Angeles" de $50 \%$, considerado relativamente elevado face os limites máximos estabelecidos em algumas normas para materiais naturais, não se pode fazer desta característica um fator decisivo para não o utilizar em um pavimento. Observe-se que a NBR 15115 (2004) não menciona limite de desgaste "Los Angeles" para agregados reciclados de resíduo de construção.

A forma do agregado reciclado estudado é cúbica e isto pode ser considerado como um bom resultado para sua aplicação em pavimentação.

Em relação à variação do peso específico aparente seco frente ao aumento da energia de compactação, verificada por meio do equipamento MCV adaptado em relação ao de Parsons (1976), observou-se que a configuração das curvas do agregado reciclado e da brita graduada mostrou-se de maneira semelhante, com expressivo aumento do peso específico aparente seco no início. A brita graduada apresentou valores de peso específico seco aparente seco mais elevados que os do agregado reciclado. 
O Índice de Suporte Califórnia do agregado reciclado aumentou significativamente com o tempo, assim como observado no experimento de Módulo de Resiliência com material in natura. Assim, o potencial pozolânico do agregado reciclado in natura possivelmente foi ativado pela compactação, que aumenta significativamente a quantidade de finos, aliada à adição de água, provocando reação pozolânica com o tempo.

Quando o ensaio de Índice de Suporte Califórnia foi realizado com brita graduada de graduação semelhante à do agregado reciclado, compactada na energia Proctor Modificada, alcançou-se valor de suporte de 96\%. Este mostrou-se inferior ao dos agregados reciclados após cura de 90 e 180 dias, compactados na energia Proctor Intermediária, cujos valores encontrados foram $117 \%$ e $125 \%$, respectivamente. O agregado reciclado em sua condição in natura (ou seja, sem aglomerantes) sofreu aumento do Índice de Suporte Califórnia com o tempo de cura a ponto de se tornar maior que o da brita graduada compactada em energia mais elevada.

Por outro lado, os ensaios de Resistência à Tração por Compressão Diametral e Resistência à Compressão Simples (que são ensaios estáticos como o ISC) realizados com o material in natura apresentaram um ganho de resistência com o tempo praticamente imperceptível.

Verificou-se ainda que a adição de $4 \%$ de cal ou $4 \%$ de cimento Portland aos agregados reciclados que seriam submetidos aos ensaios mecânicos de Resistência à Compressão Diametral, Resistência à Compressão Simples e Módulo de Resiliência, fez com que os valores obtidos nos mesmos fossem notavelmente maiores que os do material in natura. O uso de $4 \%$ de cimento Portland provoca um aumento significativo de resistência, superior aos resultados obtidos com $4 \%$ de cal. No entanto, sabe-se que o ganho de resistência dos materiais misturados a cal se dá a longo prazo, diferentemente do cimento Portland, onde isto ocorre nas primeiras idades. 
No estudo comparativo com brita graduada, o Módulo de Resiliência desta mostrouse semelhante ao do agregado reciclado aos 90 dias de cura (ou cerca de $170 \mathrm{MPa}$ a $420 \mathrm{MPa}$, dependendo da tensão de confinamento), cabendo ressaltar que ambas possuíam mesma granulometria inicial, antes da compactação.

De forma geral, os valores de resistência encontrados podem ser considerados bons. Os números referentes ao ISC do agregado reciclado se apresentaram acima de $75 \%$ (aproximadamente) para os diferentes tempos de cura analisados e, com isto, satisfizeram os limites impostos pela NBR 15115 (2004); segundo esta, o ISC de agregados reciclados em camadas de base, sub-base e reforço do subleito deve ser maior que $60 \%$ (para baixo volume de tráfego), 20\% e 12\%, respectivamente. Já em relação ao ensaio de Resistência à Tração por Compressão Diametral, embora não existam especificações para o agregado reciclado, verificou-se que o material chegou a atingir valor de $0,45 \mathrm{MPa}$ com a incorporação de $4 \%$ de cimento Portland, que é cerca de metade a um terço do que se atinge com misturas asfálticas, ou aproximadamente $1 \mathrm{MPa}$. No caso da Resistência à Compressão Simples, a NBR 15115 (2004) cita que o agregado reciclado pode ser estabilizado com cal ou cimento Portland para atingir um valor mínimo de 2,1 MPa aos 7 dias de cura; no entanto, somente a mistura com $4 \%$ de cimento Portland satisfez esta condição, pois alcançou 2,78MPa, em média, diferentemente do material com 4\% de cal que atingiu 1,38MPa, em média. Nesta mesma especificação - NBR 15115 (2004) - não há itens relacionados ao Módulo de Resiliência de agregados reciclados e, desta forma, procurou-se comparar os resultados obtidos na pesquisa com a IP-08 da PMSP (2002), que estima que o Módulo de Resiliência de materiais granulares em camadas de base deva se enquadrar entre $100 \mathrm{MPa}$ e $500 \mathrm{MPa}$; todos os valores alcançados neste estudo apresentaram-se maiores que o mínimo, e até acima do máximo no caso das misturas dos agregados reciclados com os aglomerantes, o que mostra que seus Módulos de Resiliência são similares ou superiores àqueles dos materiais tradicionalmente aceitos em pavimentação.

O ensaio de Módulo de Resiliência também foi realizado com brita graduada e apresentou resultado semelhante ao do agregado reciclado in natura após 90 dias de 
cura sob a mesma condição de graduação, energia de compactação e tensão de confinamento. Os valores verificados em ambos casos ficaram aproximadamente entre 200 e $400 \mathrm{MPa}$.

Nesta pesquisa foi possível observar os resultados de uma série de ensaios realizados por pesquisadores do Brasil e do exterior com diversos tipos de agregados reciclados. Nota-se uma diferença significativa entre os números alcançados, provavelmente devido a fatores como tipo e resistência do material (cerâmico, concreto, etc.), origem, técnicas construtivas de cada local, época em que foi realizada a obra, tipo de britagem a que o resíduo de construção foi submetido, forma de amostragem do agregado reciclado, graduação, teor de umidade, energia de compactação, possíveis erros de ensaio, etc.

No presente estudo não foram realizados ensaios para avaliar como é a influência da deformação permanente no agregado reciclado. No entanto, é preciso atentar para esta questão, uma vez que o material pesquisado sofre variações granulométricas expressivas. A quebra dos grãos deve ser induzida no processo de compactação, para que a mesma não ocorra de forma significativa durante a ação do tráfego e permita a formação da deformação permanente, com conseqüente alteração da estrutura do pavimento. Este é um ponto que ainda necessita ser estudado para melhor compreensão do comportamento do agregado reciclado. Além disso, ainda devido à propensão de mudança de granulometria, recomenda-se a utilização do agregado reciclado em vias de baixo volume de tráfego, pois o tráfego elevado poderia tornar o processo de quebra de grãos mais agressivo. Com uma grande gama de ensaios realizados não foi possível moldar uma maior quantidade de corpos-de-prova para os ensaios mecânicos, que poderiam confirmar os resultados obtidos, no entanto esta proposição fica para pesquisas futuras.

Provavelmente em função da heterogeneidade de natureza do agregado reciclado, alguns resultados obtidos nos experimentos de laboratório apresentaram dispersões. Para que estas variações diminuam, e o desempenho esperado seja alcançado, é preciso que seja dada atenção a todo o sistema de produção do agregado reciclado, de 
forma a torná-lo o mais homogêneo possível. Além disso, deve-se realizar ensaios de caracterização do material e assegurar as condições de projeto, tanto na fase de execução como na de controle de obra.

Deve-se procurar aperfeiçoar as técnicas de avaliação ou caracterização de materiais alternativos como os agregados reciclados, como mencionam Hill et al. (2001). Segundo estes autores, os ensaios tradicionais típicos indicam as propriedades de um agregado - que são então comparadas com a de outro que apresente um desempenho adequado e definem se o mesmo é apropriado - mas são uma proposição inadequada para a avaliação de materiais alternativos, já que as propriedades destes, como granulometria e estrutura química, diferem substancialmente dos materiais tradicionais.

LIMA (1999) cita que nas últimas décadas, principalmente por razões ambientais e econômicas, vários países vêm adotando a reciclagem. Levy (1999) ainda aponta que, embora "as técnicas de reciclagem dos resíduos minerais de construção civil tenham evoluído, não se pode afirmar com absoluta convicção, que a reciclagem tenha se tornado uma idéia amplamente difundida" (p.3). A autora deste trabalho acredita que isto se deve ao preconceito que ainda existe em torno dos reciclados, porém não mais se justifica, principalmente em função das normas criadas recentemente e dos resultados apresentados por pesquisas e aplicações do material em campo.

Por fim, conclui-se que o agregado reciclado de resíduo sólido da construção civil é de uso promissor como insumo na construção de bases, sub-bases e reforços do subleito de vias de baixo volume de tráfego, em substituição aos materiais convencionais. 


\section{LISTA DE REFERÊNCIAS}

ASSOCIAÇÃO BRASILEIRA DE NORMAS TÉCNICAS. NBR 7181: Solo Análise granulométrica. Rio de Janeiro, 1984.

NBR 7182: Solo - Ensaio de compactação. Rio de Janeiro, 1984.

. NBR 6954: Lastro-padrão - Determinação da forma do material. Rio de Janeiro, 1989. $\overline{1990}$.

NBR 11798: Materiais para sub-base ou base de solo-cimento. Rio de Janeiro,

. NBR 11804: Materiais para sub-base ou base de pavimentos estabilizados granulometricamente. Rio de Janeiro, 1991. 1991.

NBR 11806: Materiais para sub-base ou base de brita graduada. Rio de Janeiro,

. NBR 11803: Materiais para sub-base ou base de brita graduada tratada com cimento. Rio de Janeiro, 1991.

. NBR 15115: Agregados reciclados de resíduos sólidos da construção civil Execução de camadas de pavimentação - Procedimentos. Rio de Janeiro, 2004.

. NBR 15087: Misturas asfálticas - Determinação da resistência à tração por compressão diametral. Rio de Janeiro, 2004.

ALTERNATIVE MATERIALS IN ROAD CONSTRUCTION. 1999. Literature Review - Volume 1. Disponível em: $<$ http://www.trl.co.uk/altmat/index.htm>. Acesso em: 18 de out. 2003.

ÂNGULO, S. C.; MIRANDA, L. F. R.; JOHN, V. M. Construction and demolition waste, its variability and recycling in Brazil. In: SUSTAINABLE BUILDINGS 2002, 3., Oslo, 2002. Anais. Oslo: IISBE/GBC, 2002.

ANGULO, S. C.; KAHN, H.; JOHN, V. M.; ULSEN, C. Metodologia de caracterização de resíduos de construção e demolição. In: SEMINÁRIO DESENVOLVIMENTO SUSTENTÁVEL E A RECICLAGEM NA CONSTRUÇÃO CIVIL, 6., São Paulo, 2003. Anais. São Paulo: IBRACON, 2003.

AGÊNCIA NACIONAL DE TRANSPORTES TERRESTRES. Brasília. 2002. ANTT em números. Disponível em: $<$ http://www.antt.gov.br/destaques/ANTTemNumeros20050613.pdf $>$. Acesso em: 22 de jun. 2005. 
ARM, M. Self-cementing properties of crushed demolished concrete in unbound layers: results from triaxial tests and field tests. Waste Management and Research, v.21, p.235-239, 2001.

BENNERT, T.; PAPP JR., W. J.; MAHER, A.; GUCUNSKI, N. Utilization of construction and demolition debris under traffic-type loading in base and subbase applications. Transportation Research Record, n.1714, p.33-39, 2000.

BERNUCCI, L. L. B. Considerações sobre o dimensionamento de pavimentos utilizando solos lateríticos para rodovias de baixo volume de tráfego. 1995. 237p. Tese (Doutorado) - Escola Politécnica, Universidade de São Paulo. São Paulo, 1995.

BODI, J.; BRITO FILHO, J. A.; ALMEIDA, S. Utilização de entulho de construção civil reciclado na pavimentação urbana. In: REUNIÃO ANUAL DE

PAVIMENTAÇÃO, 29., Cuiabá, 1995. Anais. Rio de Janeiro: ABPv, 1995. p.409436.

BRITO FILHO, J. A. Cidades versus entulhos. In: SEMINÁRIO

DESENVOLVIMENTO SUSTENTÁVEL E A RECICLAGEM NA

CONSTRUÇÃO CIVIL, 2., São Paulo, 1999. Anais. São Paulo, 1999. p.56-67.

CARNEIRO, A. P.; BURGOS, P. C.; ALBERTE, E. P. V. Uso do agregado reciclado em camadas de base e sub-base de pavimentos. Projeto Entulho Bom. Salvador: EDUFBA / Caixa Econômica Federal, 2001. p.190-227.

CHAVES, A. P. Teoria e prática do tratamento de minérios. 2ed. São Paulo: Signus, 2002. v.1.

CHAVES, A. P.; PERES, A. E. C. Teoria e prática do tratamento de minérios Britagem, Peneiramento e Moagem. 2ed. São Paulo: Signus, 2003. v.3.

CONSELHO NACIONAL DO MEIO AMBIENTE. Brasília. 2002. Resolução CONAMA n' 307, de 5 de julho de 2002. Disponível em:

$<$ http://www.mma.gov.br/port/conama/res/res02/res30702.html $>$. Acesso em: $17 \mathrm{de}$ fev. 2005.

COSTA, U.; URSELLA, P. Construction and demolition waste recycling in Italy. In: INTERNATIONAL CONFERENCE ON THE ENVIRONMENTAL AND TECHNICAL IMPLICATIONS OF CONSTRUCTION WITH ALTERNATIVE MATERIALS - WASCON, 5., San Sebastián, 2003. Anais. San Sebástian: Inasmet, 2003. p.231-239.

DEPARTMENT OF THE ENVIRONMENT, TRANSPORT AND THE REGIONS. United Kingdom. 2000. Mineral planning guidance note 11 - Controlling and mitigating the environmental effects of mineral extraction in England Consultation paper. Disponível em:

$<$ http://www.odpm.gov.uk/stellent/groups/odpm control/documents/contentserverte mplate/odpm_index.hcst?n=2554\&l=2>. Acesso em: 02 de maio 2005. 
DEPARTAMENTO DE ESTRADAS DE RODAGEM DO ESTADO DE SÃO PAULO. Manual de Normas de Pavimentação. São Paulo, 1991.

DEPARTAMENTO NACIONAL DE ESTRADAS DE RODAGEM. DNER-ME 201/94: Solo-cimento - Compressão axial de corpos-de-prova cilíndricos. Rio de Janeiro, 1994.

. DNER-ME 049/94: Determinação do Índice de Suporte Califórnia utilizando amostras não trabalhadas. Rio de Janeiro, 1994.

. DNER-ME 131/94: Solos - Determinação do módulo de resiliência. Rio de Janeiro, 1994.

. Manual de Pavimentação. Rio de Janeiro, 1996. 1 CD-ROM.

. DNER-ME 035/98: Agregados - Determinação da abrasão "Los Angeles". Rio de Janeiro, 1998.

. DNER-ME 081/98: Agregados - Determinação da absorção e da massa específica de agregado graúdo. Rio de Janeiro, 1998.

DEPARTAMENTO NACIONAL DE PRODUÇÃO MINERAL. Sumário Mineral 2004. Brasília. 2004. Disponível em:

$<$ http://www.dnpm.gov.br/portal/assets/galeriaDocumento/SumarioMineral2004/AG REGADOS\%20PARA \%20CONSTRU\%C7\%C3O\%20CIVIL\%202004.pdf $>$. Acesso em: 05 de maio 2005.

DIAS, J. F. Avaliação de resíduos da fabricação de telhas cerâmicas como contribuição para seu emprego em camadas de pavimento de baixo custo. 2004. 204p. Tese (Doutorado) - Escola Politécnica, Universidade de São Paulo. São Paulo, 2004.

EMPRESA BRASILEIRA DE PLANEJAMENTO DE TRANSPORTES. Brasília. 2000. Anuário estatístico dos transportes. Disponível em:

$<$ http://www.geipot.gov.br/NovaWeb/IndexAnuario.htm>. Acesso em: 27 de out. 2003.

EUROPEAN COMMISSION. 1999. Construction and demolition waste management practices, and their economic impacts - Final Report. Disponível em: $<$ http://europa.eu.int/comm/environment/waste/studies/cdw/c\&dw report.htm $>$. Acesso em: 29 de nov. 2004.

FERNANDES, C. G. Caracterização mecanística de agregados reciclados de resíduos de construção e demolição dos municípios do Rio de Janeiro e de Belo Horizonte para uso em pavimentação. 2004. 109p. Dissertação (Mestrado) Coordenação dos Programas de Pós-Graduação de Engenharia, Universidade Federal do Rio de Janeiro (COPPE-UFRJ). Rio de Janeiro, 2004. 
FROTA, C. A. da; MENTA, C. de O.; NUNES, F. R. G. Utilização de entulho reciclado em misturas asfálticas para a região de Manaus-AM. In: REUNIÃO DE PAVIMENTAÇÃO URBANA, 12., Aracaju, 2003. Anais. Rio de Janeiro: ABPv, 2003. 1 CD-ROM.

HAMASSAKI, L.T.; SBRIGHI NETO, C.; FLORINDO, M.C. Uso de entulho como agregado para argamassas de alvenaria. In: WORKSHOP SOBRE RECICLAGEM E REUTILIZAÇÃO DE RESÍDUOS COMO MATERIAL DE CONSTRUÇÃO CIVIL. São Paulo, 1996. Anais. São Paulo: EPUSP/ANTAC, 1997. p.107-115.

HENDRICKS, F.; JANSSEN, G. M. T. Reuse of construction and demolition waste in the Netherlands for road constructions. Heron, v.46, n.2, p.109-117, 2001.

HILL, A. R.; DAWSON, A.R.; MUNDY, M. Utilization of aggregate materials in road construction and bulk fill. Journal of Resources, Conservation \& Recycling, v.32, p.305-320, 2001.

JOHN, V. M.; CINCOTTO, M. A. Contribuição apresentada à discussão da reformulação da Resolução CONAMA 307. 2003. Alternativas de gestão dos resíduos de gesso. Disponível em:

$<$ http://www.reciclagem.pcc.usp.br/ftp/Alternativas $\% 20$ para $\% 20$ gestão $\% 20 \mathrm{de} \% 20 \mathrm{re}$ siudos\%20de\%20gesso\%20v2.pdf > . Acesso em: 09 de mar. 2005.

KULAIF, Y. Análise dos mercados de matérias-primas minerais: estudo de caso da indústria e pedras britadas do Estado de SP. 2001. 144p. Tese (doutorado) Escola Politécnica, Universidade de São Paulo. São Paulo, 2001.

LEVY, S. M. Contribuição ao estudo da durabilidade de concretos, produzidos com resíduos de concreto e alvenaria. 2001. 194p. Tese (Doutorado) - Escola Politécnica, Universidade de São Paulo. São Paulo, 2001.

LIM, Y.; YANG, S.; CHO, Y.; SUH, Y.; HWANG, B.; KIM, N. Performance of recycled crushed concrete for pavement materials. Journal of the Eastern Asia Society for Transportation Studies, v.4, n.1, p.467-482, 2001.

LIMA, J. A. R. Proposição de diretrizes para produção e normalização de resíduo de construção reciclado e de suas aplicações em argamassas e concretos. 1999. 240p. Dissertação (Mestrado) - Escola de Engenharia de São Carlos, Universidade de São Paulo. São Carlos, 1999.

LUND, H. F. The McGraw-Hill recycling handbook. New York: McGraw-Hill, 1993. Cap.20., p.20.1-20.20.

LUZ, A. B.; SAMPAIO, J. A.; ALMEIDA, S. L. M. Tratamento de minérios. 4ed.. Rio de Janeiro: CETEM-MCT, 2004. 867p.

MEDINA, J.. Mecânica dos pavimentos. Rio de Janeiro: UFRJ, 1997. 380p. 
MORALES, G. Verificação e avaliação da reatividade pozolânica da cinza de lodo de esgoto da cidade de Londrina. 1994. 170p. Tese (Doutorado) - Escola Politécnica, Universidade de São Paulo. São Paulo, 1994.

NUNES, K. R. A. Avaliação de investimentos e de desempenho de centrais de reciclagem para resíduos sólidos de construção e demolição. 2004. 276p. Tese (Doutorado) - Coordenação dos Programas de Pós-Graduação de Engenharia, Universidade Federal do Rio de Janeiro (COPPE-UFRJ). Rio de Janeiro, 2004.

O’MAHONY, M. M., MILLIGAN, G. W. E. Use of recycled materials in subbase layers. Transportation Research Record, Washington, n.1310, p.73-80, 1991.

PARSONS, A. W. The rapid measurement of the moisture condition of earthwork material. Transport and Road Research Laboratory. Crowthorne, Report 750, 1976.

PINTO, T. P. Metodologia para a gestão diferenciada de resíduos sólidos da construção urbana. 1999. 189p. Tese (Doutorado) - Escola Politécnica, Universidade de São Paulo. São Paulo, 1999.

PREFEITURA DO MUNICÍPIO DE SÃO PAULO. São Paulo. 1998. São Paulo em números. Disponível em:

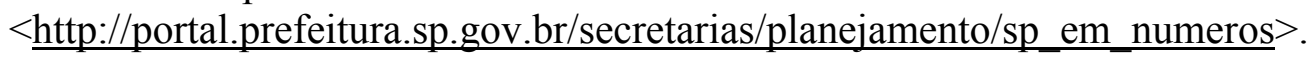

Acesso em: 26 de nov. 2004.

. São Paulo. 2002. IP-08 - Análise mecanicista à fadiga de estruturas de pavimento. Disponível em:

$<$ http://ww2.prefeitura.sp.gov.br//arquivos/secretarias/infraestruturaurbana/normas t ecnicas_de pavimentacao/ip08.pdf > . Acesso em 17 de fev. 2005.

São Paulo. 2003. PMSP/SP ETS - 001/2003 - Camadas de reforço do subleito, sub-base e base mista de pavimento com agregado reciclado de resíduos sólidos da construção civil. Disponível em:

$<$ http://ww2.prefeitura.sp.gov.br//arquivos/secretarias/infraestruturaurbana/normas t ecnicas_de pavimentacao/pmspets0012003.pdf $>$. Acesso em 06 de jul. 2005.

POON, C. S. Management and recycling of demolition waste in Hong Kong. Waste Management and Research, v.15, 561-572, 1997.

REID, J. M. Trabalho apresentado por ocasião da UNBARS Conference. United Kingdom. 2000. The use of alternative materials in road construction. Disponível em: $<$ http://www.trl.co.uk/altmat/ALT-MAT\%20final\%20rev1.dot $>$. Acesso em: 18 de out. 2003.

REZENDE, A. A. O ensaio MCV-ITA como suporte à extensão da metodologia MCT aos solos lateríticos concrecionados. 1998. 136p. Dissertação (Mestrado) Instituto Tecnológico da Aeronáutica. São José dos Campos, 1998. 
RIBEIRO, F.; SERRA, N. G. da S.; REZENDE, L. R. de R.; GUIMARÃES, R. C. Utilização de entulho da construção civil em pavimentos flexíveis. In: REUNIÃO DE PAVIMENTAÇÃO URBANA, 11., Porto Alegre, 2002. Anais. Rio de Janeiro: ABPv, 2002. 1 CD-ROM.

SANTOS, P. S. Tecnologia de argilas: Aplicações. São Paulo: Edgard Blücher, 1975. v.2.

SCHNEIDER, D. M. Deposições irregulares de resíduos da construção civil na cidade de São Paulo. 2003. 130p. Dissertação (Mestrado) - Faculdade de Saúde Pública, Universidade de São Paulo. São Paulo, 2003.

THE U.S. ENVIRONMENTAL PROTECTION AGENCY - MUNICIPAL AND INDUSTRIAL SOLID WASTE DIVISION - OFFICE OF SOLID WASTE. United States. 1998. Report $\mathbf{n}^{\mathbf{0}}$ EPA530-R-98-010 - Characterization of building-related construction and demolition debris in the United States. Disponível em: $<$ http://www.p2pays.org/ref/02/01095.pdf > . Acesso em: 03 de jan. 2005.

TRICHÊS, G.; KRYCKYJ, P. R. Aproveitamento de entulho da construção civil na pavimentação urbana. In: CONGRESSO BRASILEIRO DE GEOTECNIA AMBIENTAL, 4., São José dos Campos, 1999. Anais. São Paulo: ABMS, 1999. p.259-265.

UNIVERSITY OF TECHNOLOGY, SIDNEY. Sidney. 1999. Recycled construction and demolition materials for use in roadworks and other local government activities. Disponível em:

$<$ http://www.ipwea.org.au/upload/final_scoping_report.pdf $>$. Acesso em: 18 de out. 2003. 


\section{ANEXO A}

\section{RESOLUÇÃO CONAMA No 307, DE 5 DE JULHO DE 2002}

Estabelece diretrizes, critérios e procedimentos para a gestão dos resíduos da construção civil.

O CONSELHO NACIONAL DO MEIO AMBIENTE - CONAMA, no uso das competências que lhe foram conferidas pela Lei $\mathrm{n}^{\circ} 6.938$, de 31 de agosto de 1981, regulamentada pelo Decreto $\mathrm{n}^{\circ}$ 99.274, de 6 de julho de 1990, e tendo em vista o disposto em seu Regimento Interno, Anexo à Portaria $\mathrm{n}^{\mathbf{o}}$ 326, de 15 de dezembro de 1994, e

Considerando a política urbana de pleno desenvolvimento da função social da cidade e da propriedade urbana, conforme disposto na Lei $\mathrm{n}^{\circ} 10.257$, de 10 de julho de 2001;

Considerando a necessidade de implementação de diretrizes para a efetiva redução dos impactos ambientais gerados pelos resíduos oriundos da construção civil;

Considerando que a disposição de resíduos da construção civil em locais inadequados contribui para a degradação da qualidade ambiental;

Considerando que os resíduos da construção civil representam um significativo percentual dos resíduos sólidos produzidos nas áreas urbanas;

Considerando que os geradores de resíduos da construção civil devem ser responsáveis pelos resíduos das atividades de construção, reforma, reparos e demolições de estruturas e estradas, bem como por aqueles resultantes da remoção de vegetação e escavação de solos;

Considerando a viabilidade técnica e econômica de produção e uso de materiais provenientes da reciclagem de resíduos da construção civil; e

Considerando que a gestão integrada de resíduos da construção civil deverá proporcionar benefícios de ordem social, econômica e ambiental, resolve:

Art. $1^{\circ}$ Estabelecer diretrizes, critérios e procedimentos para a gestão dos resíduos da construção civil, disciplinando as ações necessárias de forma a minimizar os impactos ambientais.

Art. $2^{\circ}$ Para efeito desta Resolução, são adotadas as seguintes definições:

I - Resíduos da construção civil: são os provenientes de construções, reformas, reparos e demolições de obras de construção civil, e os resultantes da preparação e da escavação de terrenos, tais como: tijolos, blocos cerâmicos, concreto em geral, solos, rochas, metais, resinas, colas, tintas, madeiras e compensados, forros, argamassa, gesso, telhas, pavimento asfáltico, vidros, plásticos, tubulações, fiação elétrica etc., comumente chamados de entulhos de obras, caliça ou metralha;

II - Geradores: são pessoas, físicas ou jurídicas, públicas ou privadas, responsáveis por atividades ou empreendimentos que gerem os resíduos definidos nesta Resolução;

III - Transportadores: são as pessoas, físicas ou jurídicas, encarregadas da coleta e do transporte dos resíduos entre as fontes geradoras e as áreas de destinação;

IV - Agregado reciclado: é o material granular proveniente do beneficiamento de resíduos de construção que apresentem características técnicas para a aplicação em obras de edificação, de infraestrutura, em aterros sanitários ou outras obras de engenharia;

V - Gerenciamento de resíduos: é o sistema de gestão que visa reduzir, reutilizar ou reciclar resíduos, incluindo planejamento, responsabilidades, práticas, procedimentos e recursos para desenvolver e implementar as ações necessárias ao cumprimento das etapas previstas em programas e planos;

VI - Reutilização: é o processo de reaplicação de um resíduo, sem transformação do mesmo;

VII - Reciclagem: é o processo de reaproveitamento de um resíduo, após ter sido submetido à transformação;

VIII - Beneficiamento: é o ato de submeter um resíduo à operações e/ou processos que tenham por objetivo dotá-los de condições que permitam que sejam utilizados como matéria-prima ou produto; IX - Aterro de resíduos da construção civil: é a área onde serão empregadas técnicas de disposição de resíduos da construção civil Classe "A" no solo, visando a reservação de materiais segregados de forma a possibilitar seu uso futuro e/ou futura utilização da área, utilizando princípios de engenharia para confiná-los ao menor volume possível, sem causar danos à saúde pública e ao meio ambiente;

$\mathrm{X}$ - Áreas de destinação de resíduos: são áreas destinadas ao beneficiamento ou à disposição final de resíduos.

Art. $3^{\circ}$ Os resíduos da construção civil deverão ser classificados, para efeito desta Resolução, da seguinte forma:

I - Classe A - são os resíduos reutilizáveis ou recicláveis como agregados, tais como: 
a) de construção, demolição, reformas e reparos de pavimentação e de outras obras de infra-estrutura, inclusive solos provenientes de terraplanagem;

b) de construção, demolição, reformas e reparos de edificações: componentes cerâmicos (tijolos, blocos, telhas, placas de revestimento etc.), argamassa e concreto;

c) de processo de fabricação e/ou demolição de peças pré-moldadas em concreto (blocos, tubos, meios-fios etc.) produzidas nos canteiros de obras;

II - Classe B - são os resíduos recicláveis para outras destinações, tais como: plásticos, papel/papelão, metais, vidros, madeiras e outros;

III - Classe C - são os resíduos para os quais não foram desenvolvidas tecnologias ou aplicações economicamente viáveis que permitam a sua reciclagem/recuperação, tais como os produtos oriundos do gesso;

IV - Classe D - são os resíduos perigosos oriundos do processo de construção, tais como: tintas, solventes, óleos e outros, ou aqueles contaminados oriundos de demolições, reformas e reparos de clínicas radiológicas, instalações industriais e outros.

Art. $4^{\circ}$ Os geradores deverão ter como objetivo prioritário a não geração de resíduos e, secundariamente, a redução, a reutilização, a reciclagem e a destinação final.

$\S 1^{\circ}$ Os resíduos da construção civil não poderão ser dispostos em aterros de resíduos domiciliares, em áreas de "bota fora", em encostas, corpos d'água, lotes vagos e em áreas protegidas por Lei, obedecidos os prazos definidos no art. 13 desta Resolução.

$\S 2^{\circ}$ Os resíduos deverão ser destinados de acordo com o disposto no art. 10 desta Resolução.

Art. $5^{\circ}$ É instrumento para a implementação da gestão dos resíduos da construção civil o Plano Integrado de Gerenciamento de Resíduos da Construção Civil, a ser elaborado pelos Municípios e pelo Distrito Federal, o qual deverá incorporar:

I - Programa Municipal de Gerenciamento de Resíduos da Construção Civil; e

II - Projetos de Gerenciamento de Resíduos da Construção Civil.

Art $6^{\circ}$ Deverão constar do Plano Integrado de Gerenciamento de Resíduos da Construção Civil:

I - as diretrizes técnicas e procedimentos para o Programa Municipal de Gerenciamento de Resíduos da Construção Civil e para os Projetos de Gerenciamento de Resíduos da Construção Civil a serem elaborados pelos grandes geradores, possibilitando o exercício das responsabilidades de todos os geradores.

II - o cadastramento de áreas, públicas ou privadas, aptas para recebimento, triagem e armazenamento temporário de pequenos volumes, em conformidade com o porte da área urbana municipal, possibilitando a destinação posterior dos resíduos oriundos de pequenos geradores às áreas de beneficiamento;

III - o estabelecimento de processos de licenciamento para as áreas de beneficiamento e de disposição final de resíduos;

IV - a proibição da disposição dos resíduos de construção em áreas não licenciadas;

$\mathrm{V}$ - o incentivo à reinserção dos resíduos reutilizáveis ou reciclados no ciclo produtivo;

VI - a definição de critérios para o cadastramento de transportadores;

VII - as ações de orientação, de fiscalização e de controle dos agentes envolvidos;

VIII - as ações educativas visando reduzir a geração de resíduos e possibilitar a sua segregação.

Art $7^{\circ}$ O Programa Municipal de Gerenciamento de Resíduos da Construção Civil será elaborado, implementado e coordenado pelos municípios e pelo Distrito Federal, e deverá estabelecer diretrizes técnicas e procedimentos para o exercício das responsabilidades dos pequenos geradores, em conformidade com os critérios técnicos do sistema de limpeza urbana local.

Art. $8^{\circ}$ Os Projetos de Gerenciamento de Resíduos da Construção Civil serão elaborados e implementados pelos geradores não enquadrados no artigo anterior e terão como objetivo estabelecer os procedimentos necessários para o manejo e destinação ambientalmente adequados dos resíduos.

$\S 1^{\circ} \mathrm{O}$ Projeto de Gerenciamento de Resíduos da Construção Civil, de empreendimentos e atividades não enquadrados na legislação como objeto de licenciamento ambiental, deverá ser apresentado juntamente com o projeto do empreendimento para análise pelo órgão competente do poder público municipal, em conformidade com o Programa Municipal de Gerenciamento de Resíduos da Construção Civil.

$\S 2^{\circ}$ O Projeto de Gerenciamento de Resíduos da Construção Civil de atividades e empreendimentos sujeitos ao licenciamento ambiental, deverá ser analisado dentro do processo de licenciamento, junto ao órgão ambiental competente.

Art. $9^{\circ}$ Os Projetos de Gerenciamento de Resíduos da Construção Civil deverão contemplar as seguintes etapas: 
I - caracterização: nesta etapa o gerador deverá identificar e quantificar os resíduos;

II - triagem: deverá ser realizada, preferencialmente, pelo gerador na origem, ou ser realizada nas áreas de destinação licenciadas para essa finalidade, respeitadas as classes de resíduos estabelecidas no art. $3^{\circ}$ desta Resolução;

III - acondicionamento: o gerador deve garantir o confinamento dos resíduos após a geração até a etapa de transporte, assegurando em todos os casos em que seja possível, as condições de reutilização e de reciclagem;

IV - transporte: deverá ser realizado em conformidade com as etapas anteriores e de acordo com as normas técnicas vigentes para o transporte de resíduos;

V - destinação: deverá ser prevista de acordo com o estabelecido nesta Resolução.

Art. 10. Os resíduos da construção civil deverão ser destinados das seguintes formas:

I - Classe A: deverão ser reutilizados ou reciclados na forma de agregados, ou encaminhados a áreas de aterro de resíduos da construção civil, sendo dispostos de modo a permitir a sua utilização ou reciclagem futura;

II - Classe B: deverão ser reutilizados, reciclados ou encaminhados a áreas de armazenamento temporário, sendo dispostos de modo a permitir a sua utilização ou reciclagem futura;

III - Classe C: deverão ser armazenados, transportados e destinados em conformidade com as normas técnicas especificas.

IV - Classe D: deverão ser armazenados, transportados, reutilizados e destinados em conformidade com as normas técnicas especificas.

Art. 11. Fica estabelecido o prazo máximo de doze meses para que os municípios e o Distrito Federal elaborem seus Planos Integrados de Gerenciamento de Resíduos de Construção Civil, contemplando os Programas Municipais de Gerenciamento de Resíduos de Construção Civil oriundos de geradores de pequenos volumes, e o prazo máximo de dezoito meses para sua implementação.

Art. 12. Fica estabelecido o prazo máximo de vinte e quatro meses para que os geradores, não enquadrados no art. $7^{\circ}$, incluam os Projetos de Gerenciamento de Resíduos da Construção Civil nos projetos de obras a serem submetidos à aprovação ou ao licenciamento dos órgãos competentes, conforme $\S \S 1^{\circ}$ e $2^{\circ}$ do art. $8^{\circ}$.

Art. 13. No prazo máximo de dezoito meses os Municípios e o Distrito Federal deverão cessar a disposição de resíduos de construção civil em aterros de resíduos domiciliares e em áreas de "bota fora".

Art. 14. Esta Resolução entra em vigor em 2 de janeiro de 2003.

JOSÉ CARLOS CARVALHO

Presidente do Conselho

Publicada DOU 17/07/2002 

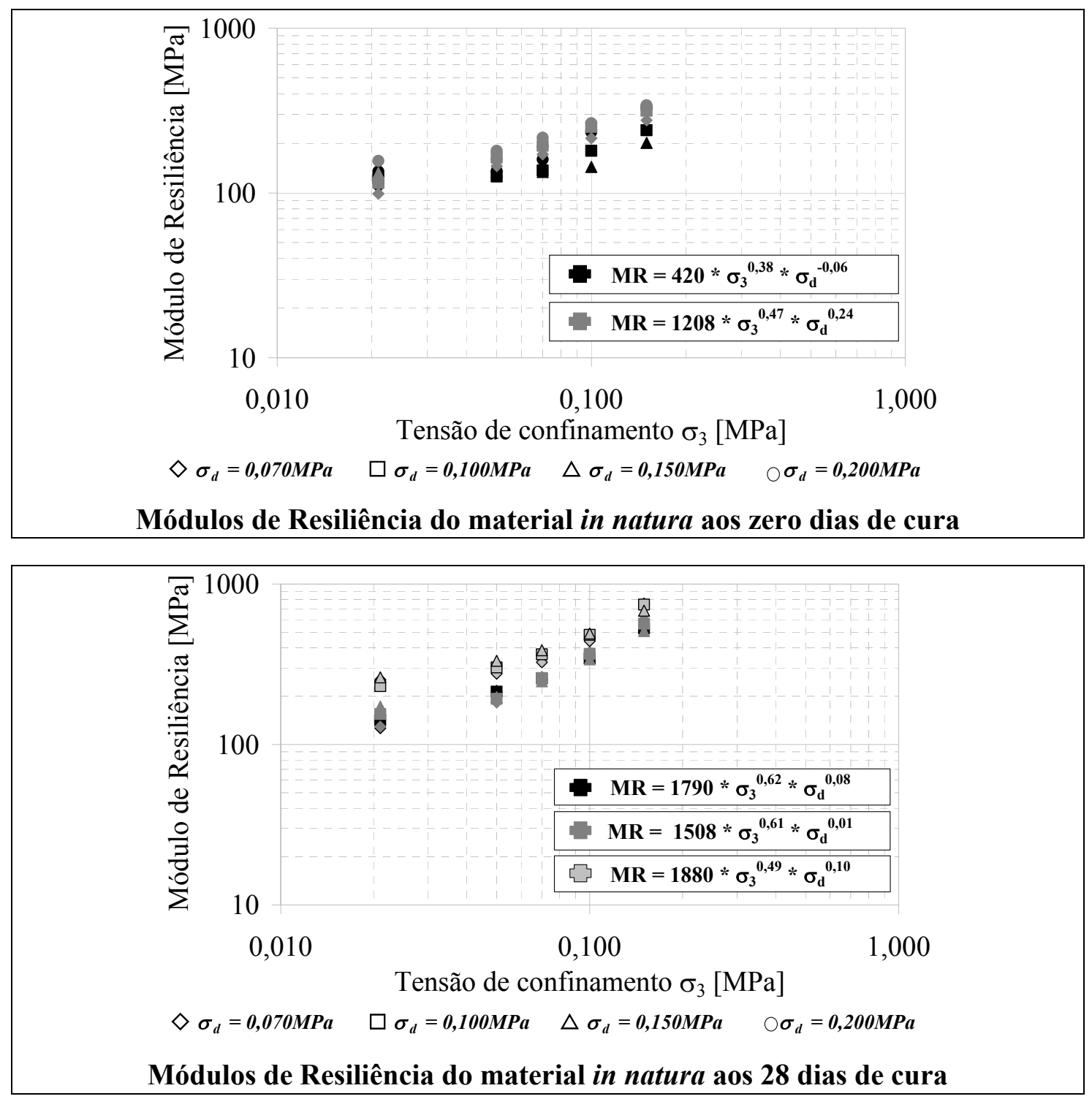

Módulos de Resiliência do material in natura aos 28 dias de cura

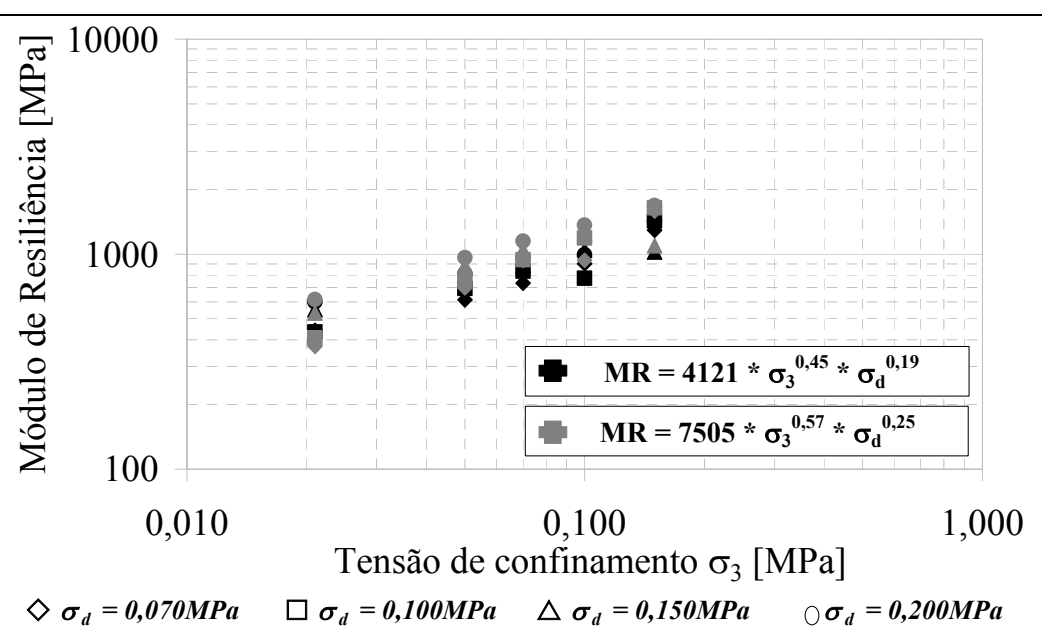

Módulos de Resiliência do material com cal aos 28 dias de cura 


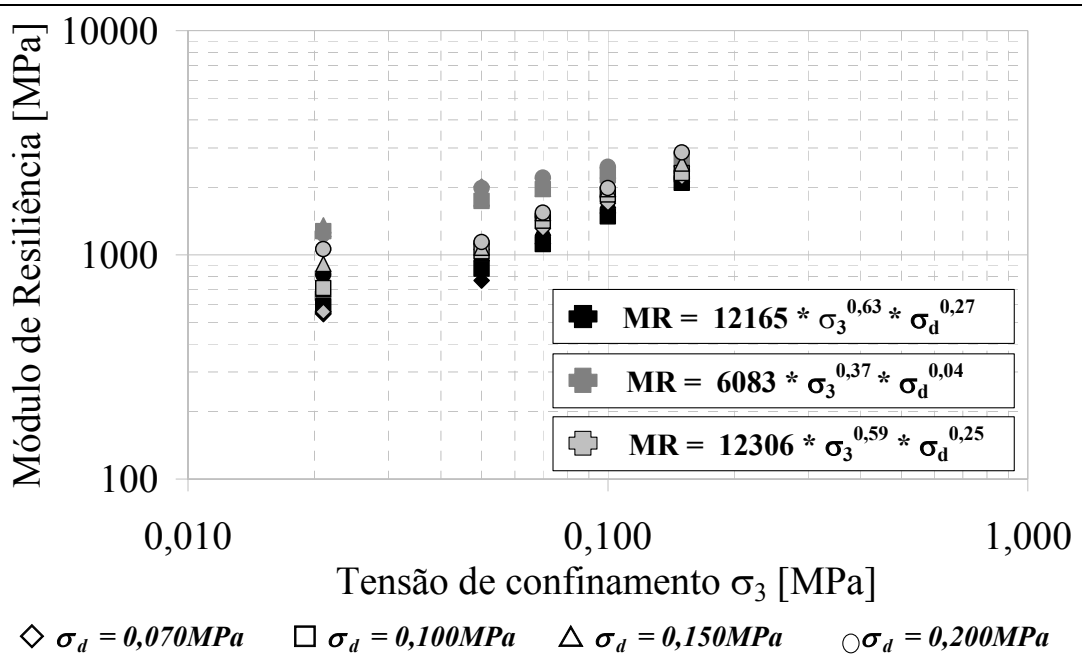

Módulos de Resiliência do material com cimento Portland aos 28 dias de cura

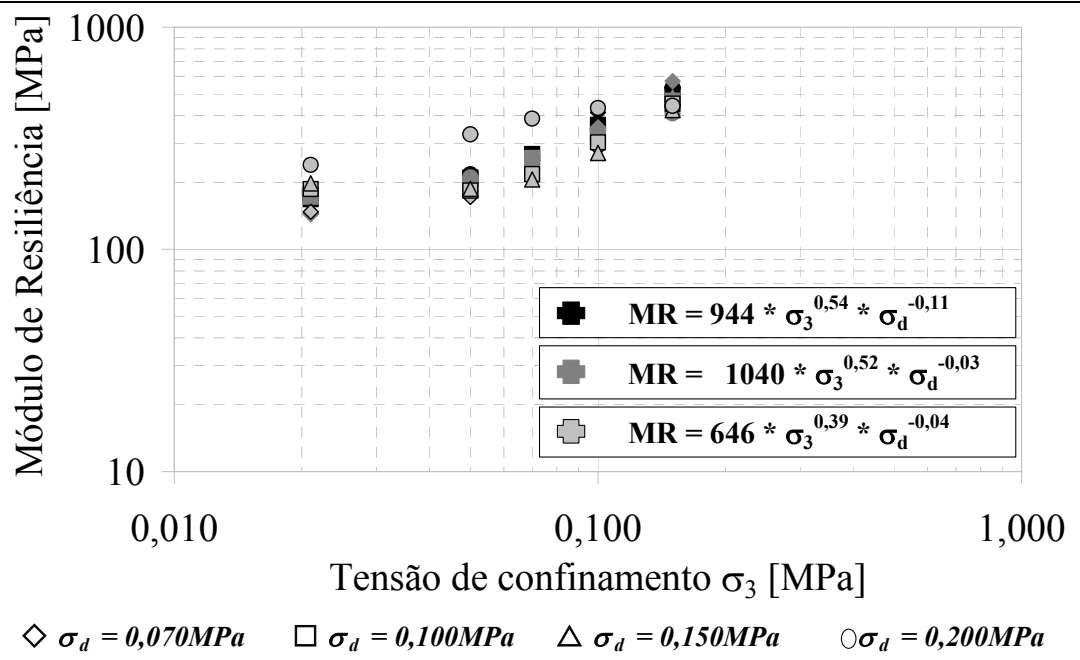

Módulos de Resiliência do material in natura aos 90 dias de cura

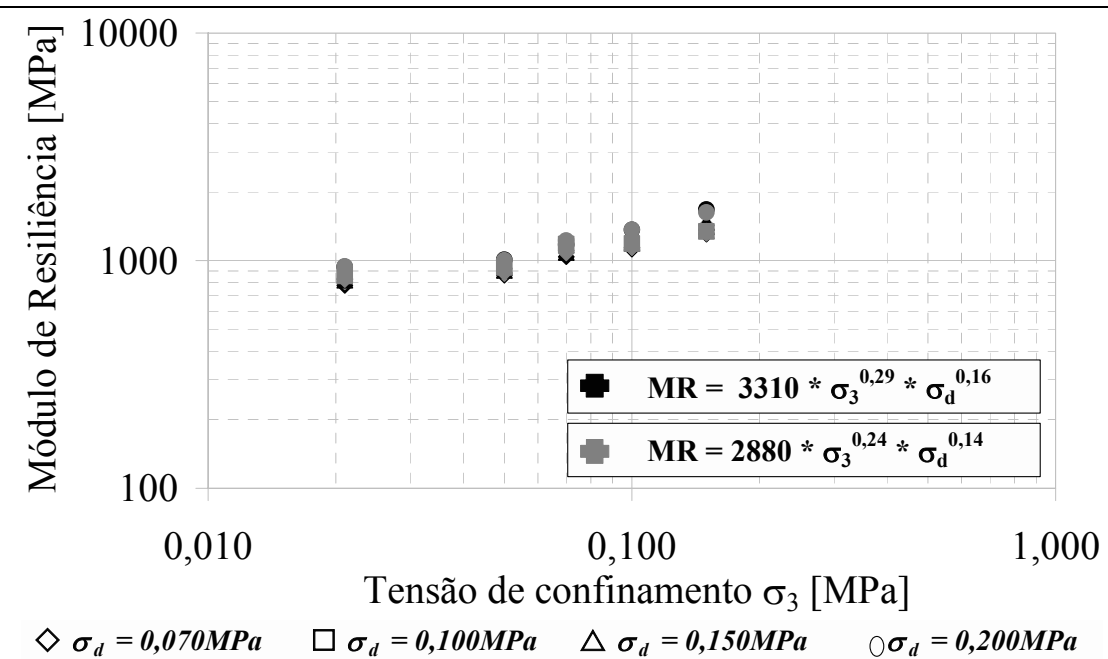

Módulos de Resiliência do material com cal aos 90 dias de cura 


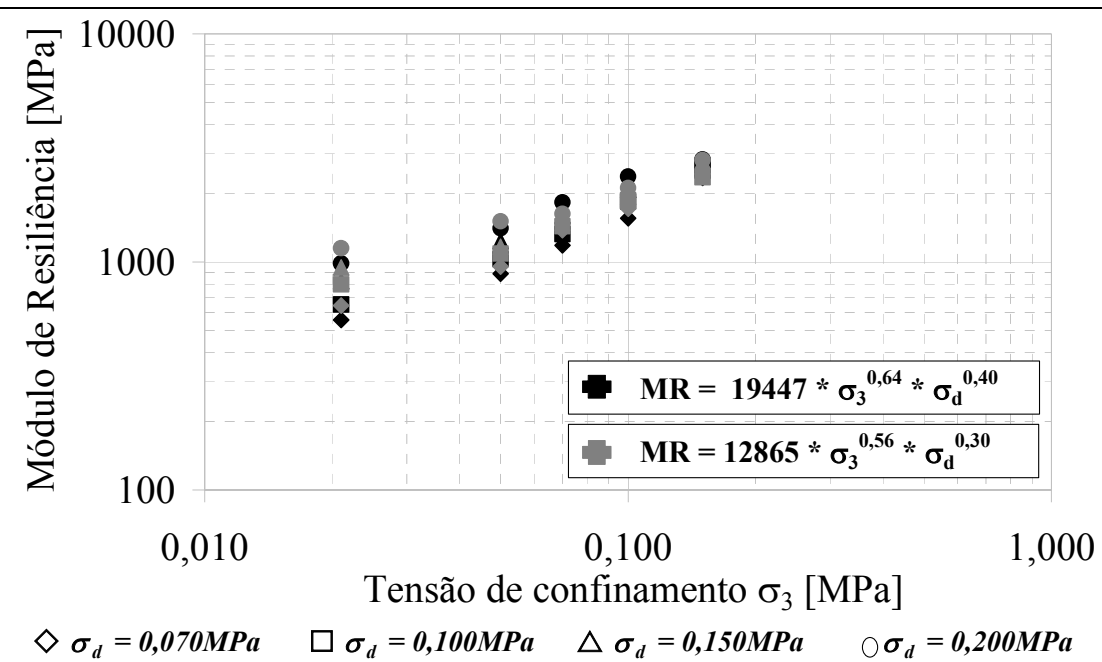

Módulos de Resiliência do material com cimento Portland aos 90 dias de cura

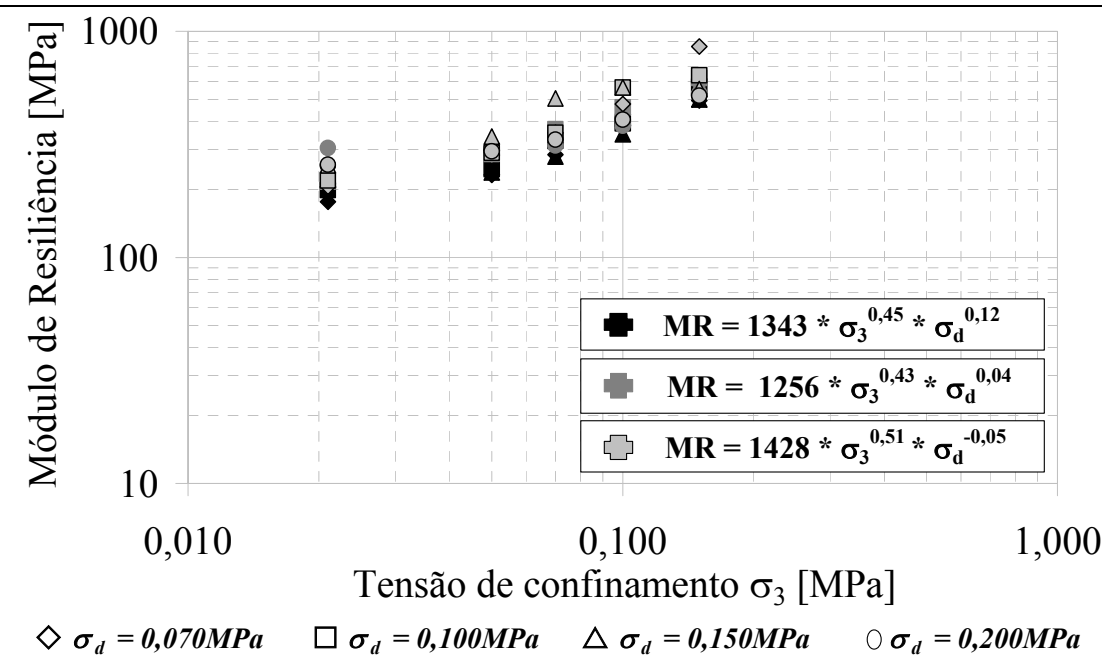

Módulos de Resiliência do material in natura aos 180 dias de cura

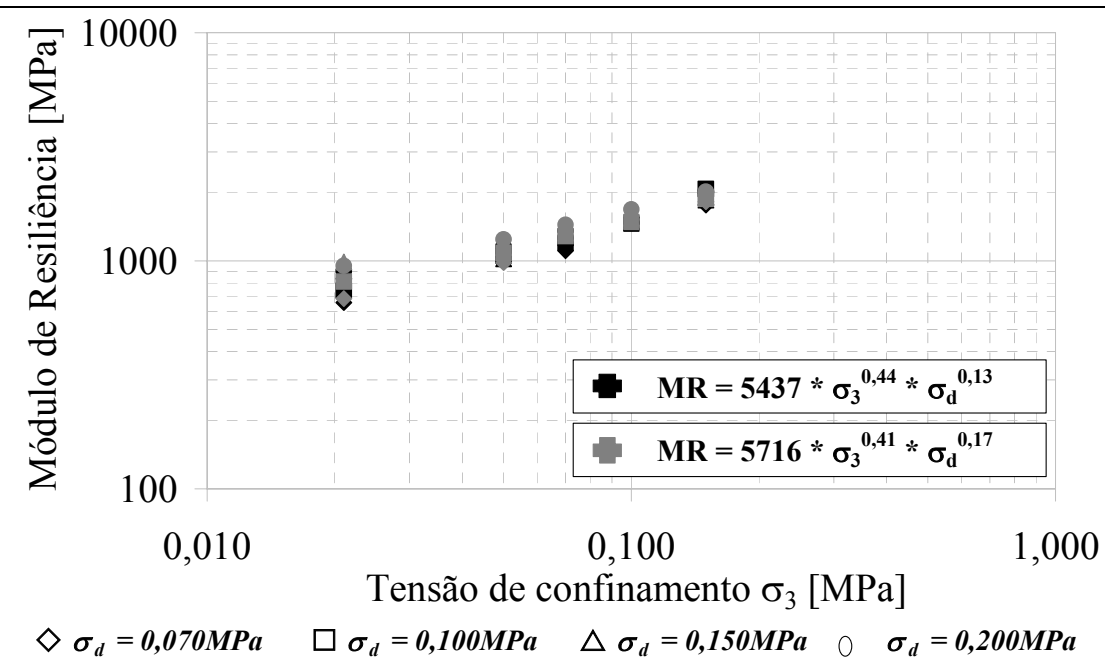

Módulos de Resiliência do material com cal aos 180 dias de cura 


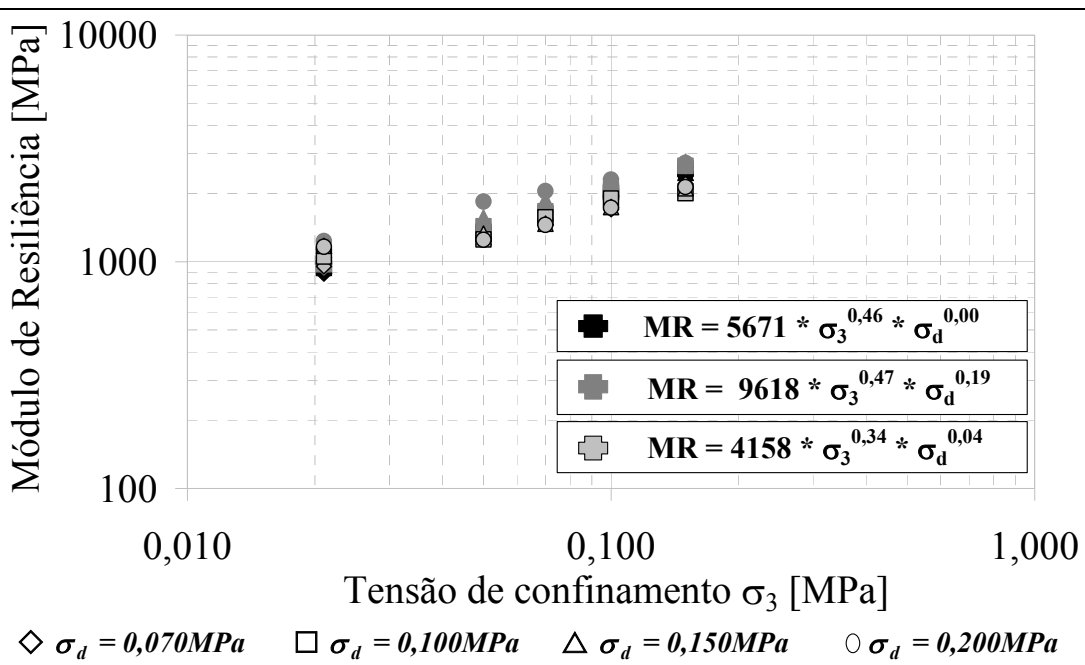

Módulos de Resiliência do material com cimento Portland aos 180 dias de cura 
